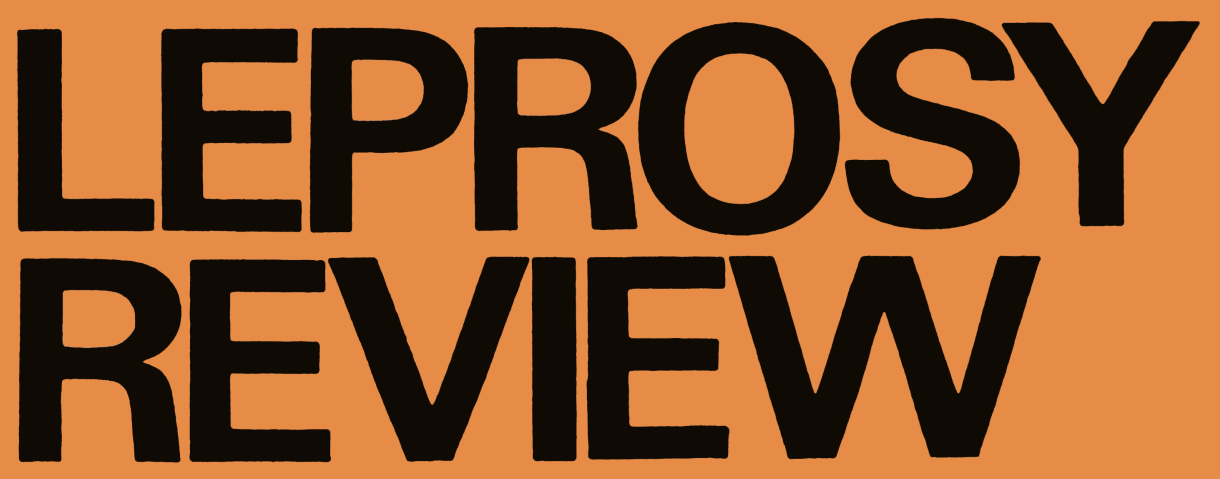

Volume 51, Supplement 1, March 1980

\title{
Leprosy in Norway
}

L. M. Irgens

Published Quarterly for the

British Leprosy Relief Association

ISSN 0305-7518 


\section{Leprosy in Norway}

AN EPIDEMIOLOGICAL STUDY BASED ON

A NATIONAL PATIENT REGISTRY

L. M. IRGENS

Institute of Hygiene and Social Medicine, University of Bergen, Norway 
(C) 1980 LEPRA Association

ISSN $0305-7518$

Printed in Great Britain at the Alden Press Oxford London and Northampton 


\section{Contents}

Acknowledgements $\quad$ ix

Summary $\quad x i$

1. Introduction 1

1.1. Background 1

1.2. Purpose 2

2. Material and methods 3

2.1. Geographical and demographical aspects of Norway 3

2.2. Computerization of the registry information 5

2.2.1. Sources of data 5

District register $\quad 5$

Hospital register 10

Hospital patient records 10

$\begin{array}{ll}\text { 2.2.2. Procedure of computerization } & 10\end{array}$

Choice of material 10

Organization of patient records and technical transfer 11

Identification of patient reports and patient records 13

Checking and completion of data 13

Search for doublet records $\quad 14$

2.2.3. Results 15

2.2.4. Comments 16

2.3. Evaluation of the material 17

2.3.1. Material used in the evaluation 18

$\begin{array}{ll}\text { 2.3.2. Procedure of evaluation } & 18\end{array}$

2.3.3. Results 19

Organization 19

Case finding 20

Follow up 20

Diagnostic criteria $\quad 21$

Validity 22

Completeness 23

Reliability $\quad 25$

$\begin{array}{ll}\text { 2.3.4. Comments } & 27\end{array}$

2.4. Additional sources of data 29

2.4.1. Leprosy cases 29

2.4.2. Total population 29 
2.4.3. Environmental factors 29

2.5. Methods 29

2.5.1. Definition of observation period 29

2.5.2. Definition of geographical areas 30

$\begin{array}{ll}\text { 2.5.3. Epidemiological measures } & 31\end{array}$

2.5.4. Statistical tests 33

2.5.5. Special procedures 33

Distribution according to sex, age and type 33

Prediction of incidence rates 34

Isolation of patients $\quad 35$

Leprosy in families $\quad 36$

Leprosy in a high frequency district 36

3. Results

3.1. Geographical distribution

3.1.1. The observation period as a whole 41

High frequency areas 41

Low frequency areas $\quad 41$

Towns and rural districts $\quad 44$

Coast and inland $\quad 44$

3.1.2. Time trends during the observation period 46

High frequency areas $\quad 49$

Low frequency areas $\quad 49$

Towns and rural districts $\quad 50$

Coast and inland $\quad 50$

3.1.3. Distribution according to some climatic variables 50

Humidity 51

Temperature $\quad 52$

3.1.4. Comments $\quad 52$

3.2. Distribution according to sex, age and type 54

3.2.1. Distribution by sex $\quad 54$

According to place $\quad 54$

According to year of onset $\quad 54$

According to age $\quad 55$

According to age by year of onset $\quad 56$

3.2.2. Distribution by age 59

According to place $\quad 59$

According to year of onset $\quad 60$

According to year of birth 61

$\begin{array}{ll}\text { 3.2.3. Distribution by type } 62 & 62\end{array}$

According to sex and place 62

According to sex and year of onset 63

According to sex and year of birth 65

$\begin{array}{ll}\text { According to sex and age } & 72\end{array}$ 
According to sex and age by year of onset

3.2.4. Movements in the diagnostic spectrum 73

3.2.5. Comments 76

3.3. Prediction of incidence rates based on information on sex, age and type

3.3.1. Level of incidence rates

3.3.2. Time trend in incidence rates

3.3.3. Evaluation

3.3.4. Comments

3.4. Isolation of patients and trends in subsequent incidence rates 80

3.4.1. Prevalence rates and subsequent incidence rates 81

3.4.2. Isolation and subsequent relative fall in incidence rates 81

3.4.3. Comments 84

3.5. Leprosy in families 85

3.5.1. All patients mutually related 85

3.5.2. Sibships 86

$\begin{array}{ll}\text { 3.5.3. Parents and children } & 87\end{array}$

3.5.4. Marriages 88

3.5.5. Comments $\quad 89$

3.6. Leprosy in a high frequency district 89

3.6.1. District level 91

3.6.2. Countryside level 94

3.6.3. Farm level 95

Distance from the sea $\quad 95$

Malnutrition $\quad 97$

Poverty 100

Overcrowding 100

Sphagnum vegetation $\quad 101$

A comparison of environmental variables 102

$\begin{array}{ll}\text { 3.6.4. Comments } & 103\end{array}$

$\begin{array}{ll}\text { 4. Discussion } & 107\end{array}$

4.1. General background 107

4.2. Interpretations and inferences 108

4.2.1. Geographical distribution 108

Communications $\quad 108$

Mycobacteria in the environment and tuberculosis 109

Malnutrition 111

Overcrowding 111

Genetic factors $\quad 112$

4.2.2. Decline 112

Malnutrition $\quad 112$

Mycobacteria in the environment and tuberculosis 112

Emigration 
Isolation $\quad 113$

4.2.3. Sex, age and type 114

Age-specific incidence rates 115

Age-specific incidence rates and level of incidence 116

Age-specific incidence rates according to year of onset and year of birth 116

Sex specific incidence rates $\quad 117$

$\begin{array}{ll}\text { Type index } & 117\end{array}$

Bias in the registration $\quad 118$

Predictions of incidence rates $\quad 119$

Features in other countries $\quad 119$

Movements in the diagnostic spectrum $\quad 121$

$\begin{array}{ll}\text { 4.2.4. Occurrence in families } & 121\end{array}$

Present findings $\quad 122$

Other studies $\quad 123$

4.3. Concluding remarks 124

$\begin{array}{ll}\text { References } & 127\end{array}$ 


\section{Acknowledgements}

The present study was carried out at the Institute of Hygiene and Social Medicine, University of Bergen. However, I am very much indebted to Professor Erik Waaler, MD, former head of the Department of Pathology, who as a chairman of the Organizing Committee, Tenth International Leprosy Congress (Bergen, 1973), suggested this area of research. Furthermore, I wish to express my sincere gratitude to the former head of the Institute of Hygiene and Social Medicine, Professor Tor Bjerkedal, MD, M P H. His interest and enthusiasm as well as sound scepticism and criticism were of great importance to the study. Working facilities and assistance have been provided at the Institute for which I am most grateful. I also want to thank Professor Anders Chr Gogstad, MD, the present head of the Institute. The secretarial assistance of Mrs Solveig Lexander and Mrs Harriet Torvund has been of great help and is highly appreciated.

I want to express my gratitude for the most valuable assistance given by The EDP Section of The Faculty of Medicine; Mrs Anne Grethe Sleire Graham and Mrs Sonja Antoniazzi for punching, and cand real Rolv Skjærven, cand real Geir Egil Eide, cand real Dag Vaula, cand real Alf Aksland, dr. philos. Ivar Heuch, cand real Siri Nome Eikhom and siv ing Ove Eriksen for programming and statistical advice of various kinds. Linguistic correction of the manuscript was kindly undertaken by Julia Anthonisen, B.Sc., to whom I am greatly indebted.

I also want to express my gratitude to Jindrich Kazda, PhD, Forschunginstitut Borstel, West Germany. The cooperation with him has been most valuable.

I am indebted to The National Archives (Bergen and Oslo), The Bergen Collections on the History of Medicine and the Medical Section of the University Library for kind assistance.

I have received financial support from Norwegian Research Council for Science and the Humanities (NAVF), British Leprosy Relief Association (LEPRA), Norwegian Agency for International Development (NORAD), Rebekka Ege Hegermanns Legat, The Gade Foundation and Armauer og Klaus Hanssens fond. All support is gratefully acknowledged. 



\section{Summary}

The study was based on The National Leprosy Registry of Norway, established in 1856 and in operation until the last patients were registered in the 1950s. Information on all 8,231 patients was transferred to a computer file, which, together with the original sources, formed the basis for an evaluation of the material. Diagnostic criteria with respect to the disease and the type of disease, and principles as well as practical aspects of case finding in the field, substantiated the Leprosy Registry as a satisfactory basis for an epidemiological study.

Leprosy was frequent in West and North Norway and particularly in the coastal health districts. The disease was inf requent in towns and was almost unknown in East Norway. The top of the endemic was reached in the middle of the 19th century with prevalence (per 10,000) and incidence (per 100,000 per year) rates of $16 \cdot 7$ and $16 \cdot 6$ for the whole country (mean population: $1,984,791), 101 \cdot 1$ and $97 \cdot 5$ for the top frequency county (mean population: 87,074 ), and $253 \cdot 0$ and 318.3 for the top frequency district (mean population: $2,609)$.

Sex ratio, based on age-adjusted sex-specific incidence rates of patients taken ill during the observation period 1851-1920, was $142 \cdot 6$. Sex ratio was highest in the age group 30-49 years (187.1) and increased from the first decade of the observation period (136.4) to the last (160.3). Highest average annual incidence rates were found in the age group 15-29 years (13.5) in females, and in the age group 30-49 years (19.9) in males. Mean age at onset by year of onset in males and females increased through the observation period from 33.0 and 32.9 to 45.9 and 43.9 respectively, with a total mean of 34.3 and 33.0 in males and females. Mean age at onset by year of birth in males and females descreased through the observation period from 23.1 and 22.9 for patients born 1841-50, to $15 \cdot 1$ and $10 \cdot 7$ for patients born 1891-1900. The relative frequency of lepromatous cases was $53.8 \%$. In the age group 25-60 years, lepromatous cases were more frequent in males than in females. In the top frequency health district, compared with the low frequency areas, mean age at onset and sex ratio were low, while the relative frequency of lepromatous cases was high.

The association between mean age at onset, sex ratio and relative frequency of lepromatous cases on one hand, and level of incidence rates on the other was high $(r=0.74)$, and so was the association between the same variables and time trend in incidence rates $(r=0 \cdot 70)$. A high association was also found to exist 
between degree of isolation and relative fall in incidence rates when prevalence rates exceeded $15 \cdot 0(r=0 \cdot 81)$.

In families, relative frequency of lepromatous cases increased by number of patients per family. In sibships, patients tended to be more concordant with respect to the type than expected, except in sibships of patients taken ill after the age of 30 years. Secondary attack rate among spouses was $5 \cdot 3 \%$. Degree of concordance with respect to type in spouses did not differ from what was expected.

In the top frequency health district, the occurrence of leprosy at farm level was associated with a low production of oats and milk, and favourable conditions in the surroundings for growth of mycobacteria in sphagnum vegetation. 


\section{Introduction}

\subsection{Background}

Most of the areas where leprosy is found today, belong to developing countries. Concurrent with an increasing awareness of the public health problems in these countries in general, the necessity of solving the leprosy problem has become more and more apparent. Primary prevention represents the only satisfactory solution to the problem, and primary prevention has to be based on epidemiological knowledge. However, the epidemiology of leprosy is still only known to some extent. Apparently, M. leprae is a necessary but not sufficient factor. To assess the significance of other factors, such as standard of living in general, specific environmental factors and genetic factors, has been most difficult.

This lack of knowledge has several causes. Traditionally, leprosy has been considered to be a disease of the underprivileged, and limited resources have been available to investigate and combat the disease. Furthermore, the study of the epidemiology of leprosy represents a difficult task; accurate knowledge of all cases and of the population at risk is hard to obtain in areas where leprosy is most frequent today (Lechat, 1973).

Epidemiological studies of leprosy will not only require money and manpower. Due to the considerable incubation period, long periods of observation are also required. This is particularly the case when control measures are to be assessed. There is, therefore, a special need to evaluate and utilize for epidemiological purposes, relevant data already gathered in medical files and registers.

In Norway in the middle of the last century, leprosy represented a considerable public health problem (Irgens, 1973). Information on the total population is at hand in general population censuses, from 1865 organized as nominative censuses. Detailed information on leprosy patients has been obtained through compulsory notification of all cases, enforced by a Royal Decree of 1856. Routines of central registration were carried into effect the same year (Irgens and Bjerkedal, 1973); routines which formed the basis for a central national patient registry. The material covers a period of high rates of the disease followed by a rapid decline. Today, the disease is almost eradicated. The epidemiological development is in detail documented through this National Leprosy Registry of Norway. 


\subsection{Purpose}

In brief, the purpose was to present, from an epidemiological point of view, the complete story of leprosy in Norway from the middle of the last century until today, based on a prospective, 'historical', longitudinal study, utilizing routinely recorded data.

The considerable amount of data, conventionally represented in handwritten registers, has, up to the present, made it impossible to utilize more than fragments of the total material in scientific studies. Accordingly, one aim of the study was, on the basis of all the material, and aided by EDP-techniques, to trace epidemiological features of leprosy in Norway in an attempt to clarify some aspects of the epidemiology of the disease in general.

However, from a general epidemiological point of view, the material of the study, based on a national patient registry established in the middle of the 19th century, was, in itself, quite extraordinary. Accordingly, a subsidiary aim of the study was to pinpoint technical and analytical questions related to the utilization of this source of data which, at the time of its establishment, represented a unique methodological innovation also involving important implications for today.

The organization of the fight against leprosy in Norway in general, and the establishment of the Leprosy Registry have been related in previous articles (Irgens, 1973; Irgens and Bjerkedal, 1973).

In the present study a computerized version of the registry provided information on leprosy cases. Special emphasis is placed on the construction of this version, transforming data to a representation compatible with computer techniques and transferring them from the conventional registers to a computer file. Likewise, an evaluation of the material with respect to its usefulness in epidemiological studies is related.

The material has been compiled describing time trends with respect to geographical distribution, and with respect to age- and sex-specific incidence rates, and type index.

Associations found to exist between mean age at onset, sex ratio and type index on one hand, and incidence rates on the other, have been used in an attempt to predict incidence rates. Isolation was the most radical preventive measure taken against the disease in Norway, and the effectiveness of the measure, in terms of lowered incidence rates, has been evaluated. Furthermore, the occurrence of leprosy among relatives has been analysed. In the district with the highest morbidity rates in Norway, the occurrence of leprosy at farm level has been compared with a set of environmental variables.

Each part of the results chapter ends with comments restricted to the particular subject, and in a final discussion the consistency of the findings with relevant hypotheses and current theories is considered. 


\section{Materials and Methods}

\subsection{Geographical and demographical aspects of Norway}

Norway is situated between latitude $58-71^{\circ} \mathrm{N}$, and longitude $4-31^{\circ} \mathrm{E}$. The area amounts to approximately 300,000 square kilometres (Fig. 1).

The southern part of the country is divided by a high mountain plateau into eastern and western regions. In the eastern regions, agriculture and forestry represented the main occupation far into the 20th century. In the western regions, the land is split up by numerous fjords along which the population has been localized. The areas of agriculture and forestry are small but have been intensively exploited. Fishing has represented an important trade.

In the northern part of the country, Trøndelag and North Norway, the conditions along the coast correspond well with the western regions of South Norway. The inland is more similar to eastern regions of South Norway. With some exceptions, all inhabitants have been living near the coast where fishing has been an important trade.

An inland climate (Historical Statistics, 1968) is found in eastern regions of South Norway; dry with a relatively low temperature during the winter and high in the summer. The highest monthly 24-h mean air temperature in Oslo (Fig. 1), average $1931-60$, is approximately $17^{\circ} \mathrm{C}$ recorded in July, and the lowest is approximately $-5^{\circ} \mathrm{C}$ recorded in January. The mean amount of rainfall is approximately $800 \mathrm{~mm}$ per year.

Western regions have a coastal climate; humid with a relatively higher temperature during the winter and lower in the summer. The highest monthly mean air temperature in Bergen (Fig. 1) is approximately $15^{\circ} \mathrm{C}$ recorded in July, and the lowest approximately $1^{\circ} \mathrm{C}$ recorded in January. The mean amount of rainfall is approximately $1900 \mathrm{~mm}$ per year.

In Trøndelag and North Norway a combination of coastal and inland climate is found, but more cool than in South Norway. In Troms $\phi$ (Fig. 1) the highest mean air temperature is approximately $12^{\circ} \mathrm{C}$ recorded in July, and the lowest approximately $-4^{\circ} \mathrm{C}$ recorded in January. The mean amount of rainfall is approximately $1000 \mathrm{~mm}$ per year.

The climate does not appear to have changed considerably during the last 130 years (Mohn, 1921).

The total population of Norway (Historical Statistics, 1968) increased from $1,490,047$ in 1855 to $2,649,775$ in 1920 by which time all leprosy patients except 14 had been taken ill. Population per square kilometre increased from 


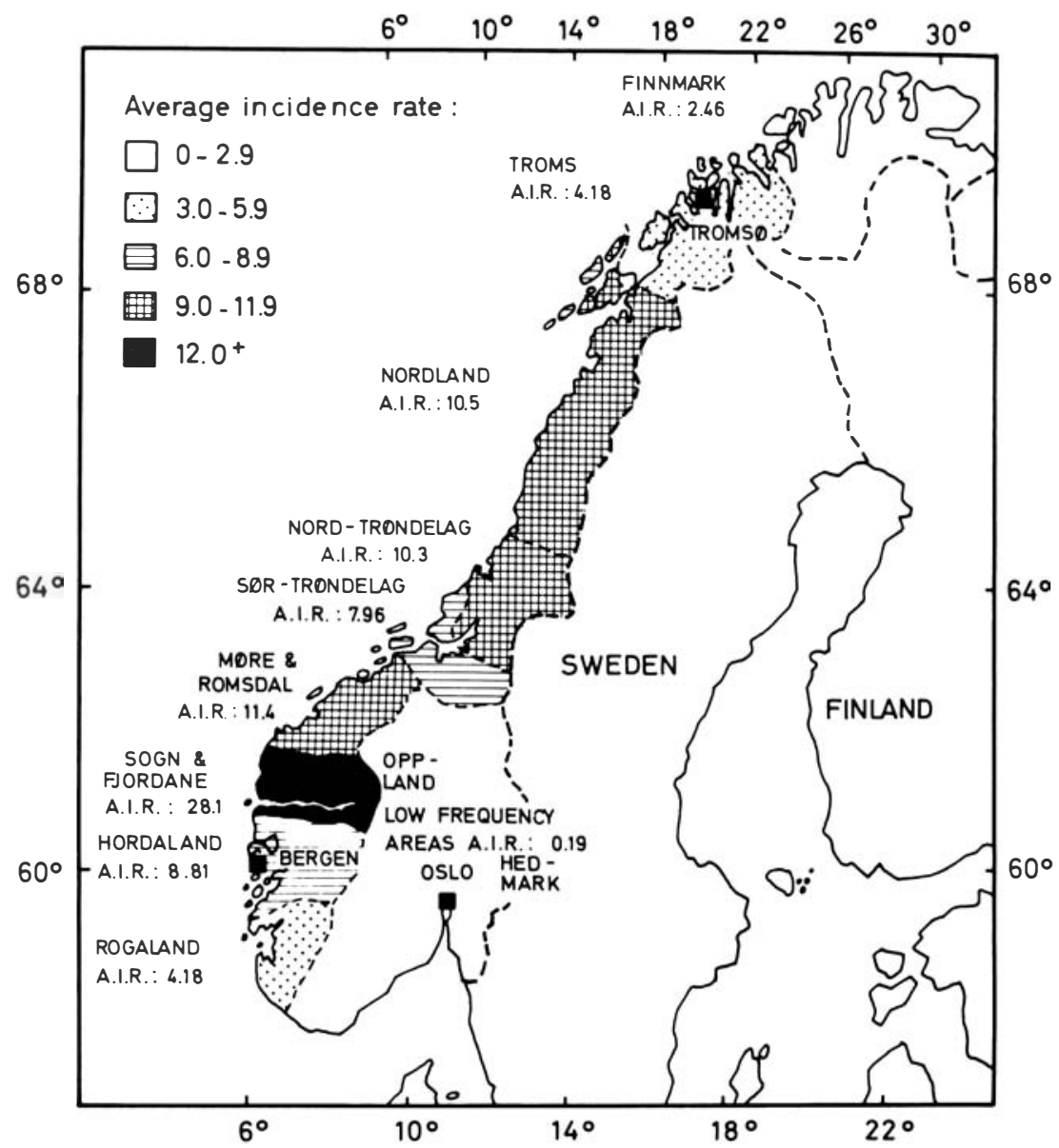

Figure 1. Average incidence rates (A.I.R.) of leprosy in Norway 1851-1920 by county. (The National Leprosy Registry of Norway.)

4.8 in 1855 to 8.6 in 1920 . During the same period the number of females to 1,000 males increased from 1,041 to 1,053 . In $1855,36.4 \%$ of all males and $33.6 \%$ of all females were less than 15 years of age. In 1920, the corresponding figures were $33.6 \%$ and $30.6 \%$. In $185586.7 \%$ of the total population lived in rural municipalities and $83.1 \%$ in sparsely populated areas. Corresponding figures in 1920 were $70.4 \%$ and $54.7 \%$. In $1855,53.4 \%$ of the population lived in the eastern regions of South Norway and 53.6\% in 1920.

Accordingly, climatic and occupational conditions have not changed to any extent during the period 1855-1920. The population increased considerably and most of all in the towns, however, the composition of the population with respect to age and sex was not altered much. 


\subsection{Computerization of the registry information}

According to the official statistics of Norway, 8,218 cases of leprosy were reported from 1856 to 1945 (Melsom, 1948). For each case a considerable amount of data has been collected from primary registration until death or permanent cure. Due to the amount of data, the compilation of the total material of the Leprosy Registry called for the application of computer methods described in the following paragraphs.

\subsubsection{SOURCES OF DATA}

At the central office (Irgens and Bjerkedal, 1973) the information was kept in two coordinate registers; the district register and the hospital register.

\section{District register}

Information was forwarded annually by the District Health Officer, in charge of his health district, to the central office in two separate report forms providing columns for the items of personal data to be recorded.

A main form (Fig. 2) was used for the notification of all new cases registered by the District Health Officers each year; either patients taken ill while living in the district or patients who migrated to the district after onset of the disease. The latter had already been notified in another district.

In a follow up form (Fig. 3), additional information on patients already registered was reported. The form was used to inform the central office when a patient left the district, either for hospitalization or migration to another district. The form was also used for the notification of deaths and to inform the central office when a case, after observation, turned out to represent another disease and not leprosy.

In the central office most of the information was transferred to the district register which was kept in handwritten books. The pages are structured with separate columns for the different items of data to be transferred (Fig. 4, Table 1). Information from a main form on one patient was entered on one line and is called a patient report. Each patient report was identified by a district serial number consisting of 7 digits.

The first digit referred to the number of the register book in which the patient report is found. The next three digits referred to the page number. A full page was reserved for patient reports from one particular health district. The last three digits referred to the number of the line on which the report is entered, starting from no. 001 for the first patient report forwarded from each health district.

Because more than one patient report per person might have been forwarded to the central office and entered into the district register, one patient might have been allotted more than one district serial number. In many cases cross 


\section{Schematisk Forklaring}

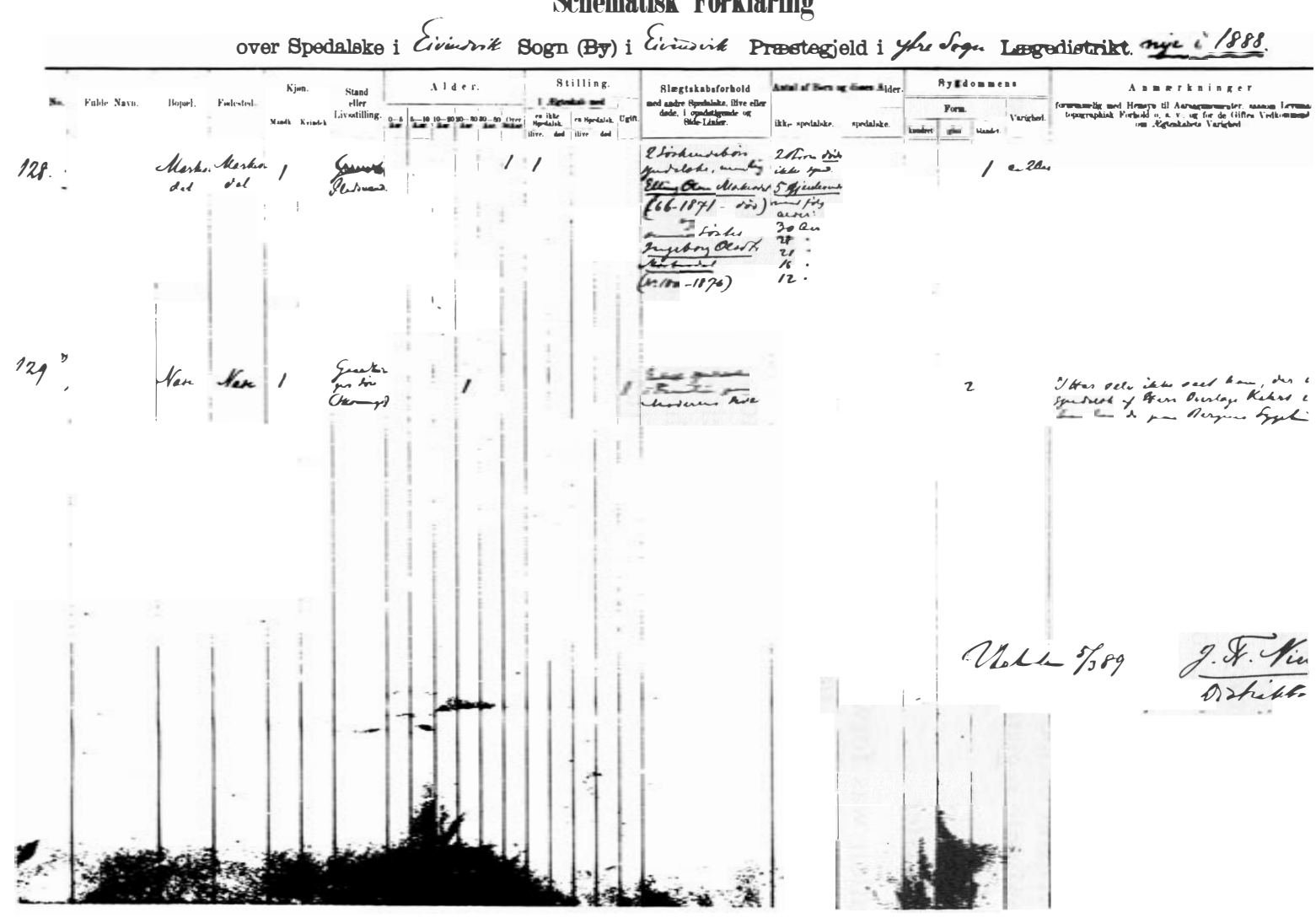

Figure 2. Form used for the notification by the District Health Officers of new leprosy cases to the Chief Medical Officer for Leprosy. (The National Leprosy Registry of Norway.) 


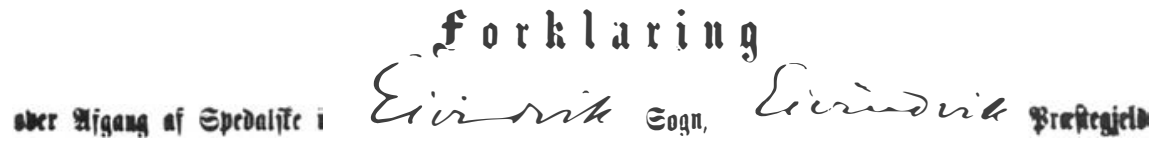
i garct 1588 .

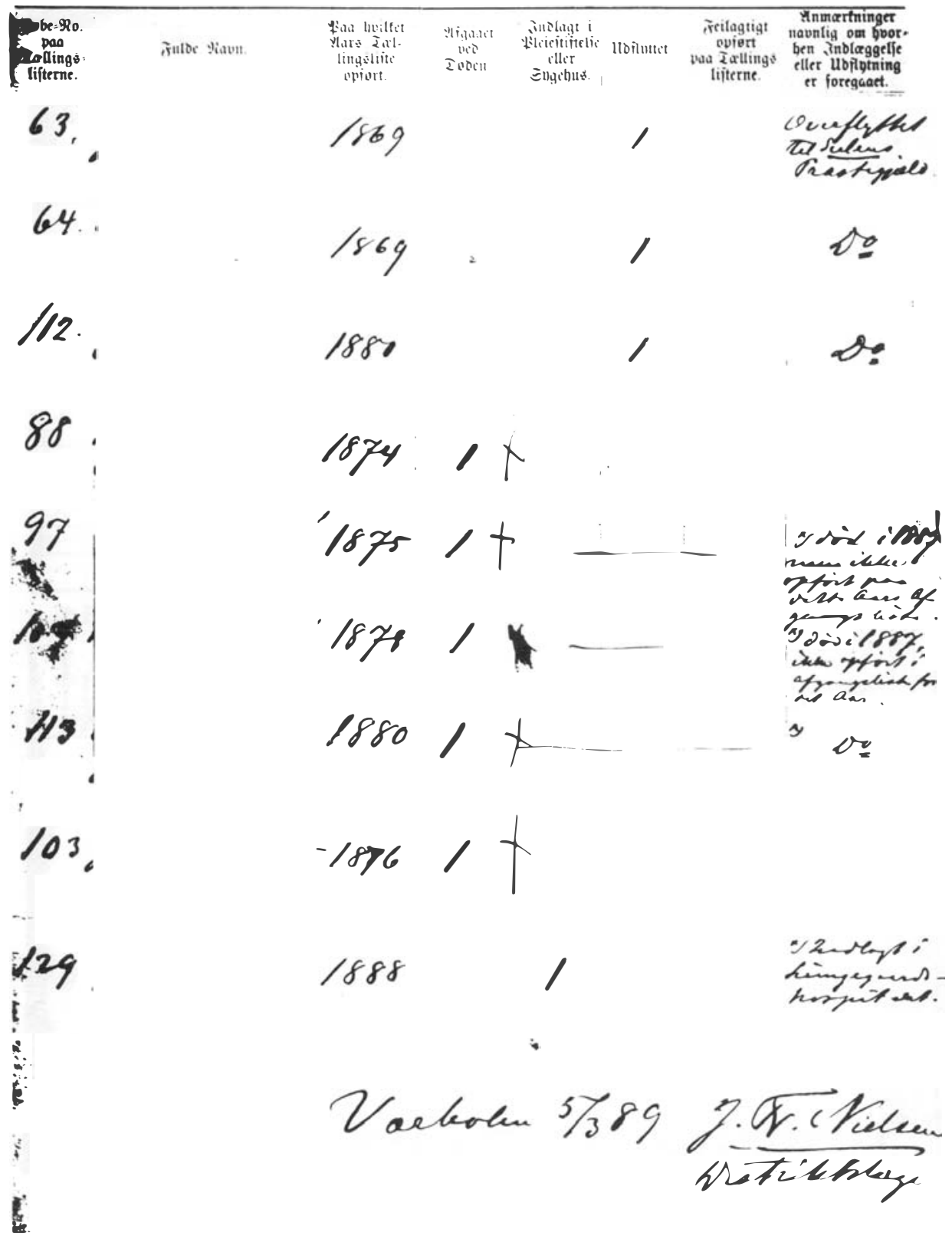

Figure 3. Form used for the reporting by the District Health Officers of follow-up information on cases already registered to the Chief Medical Officer for Leprosy. (The National Leprosy Registry of Norway.) 


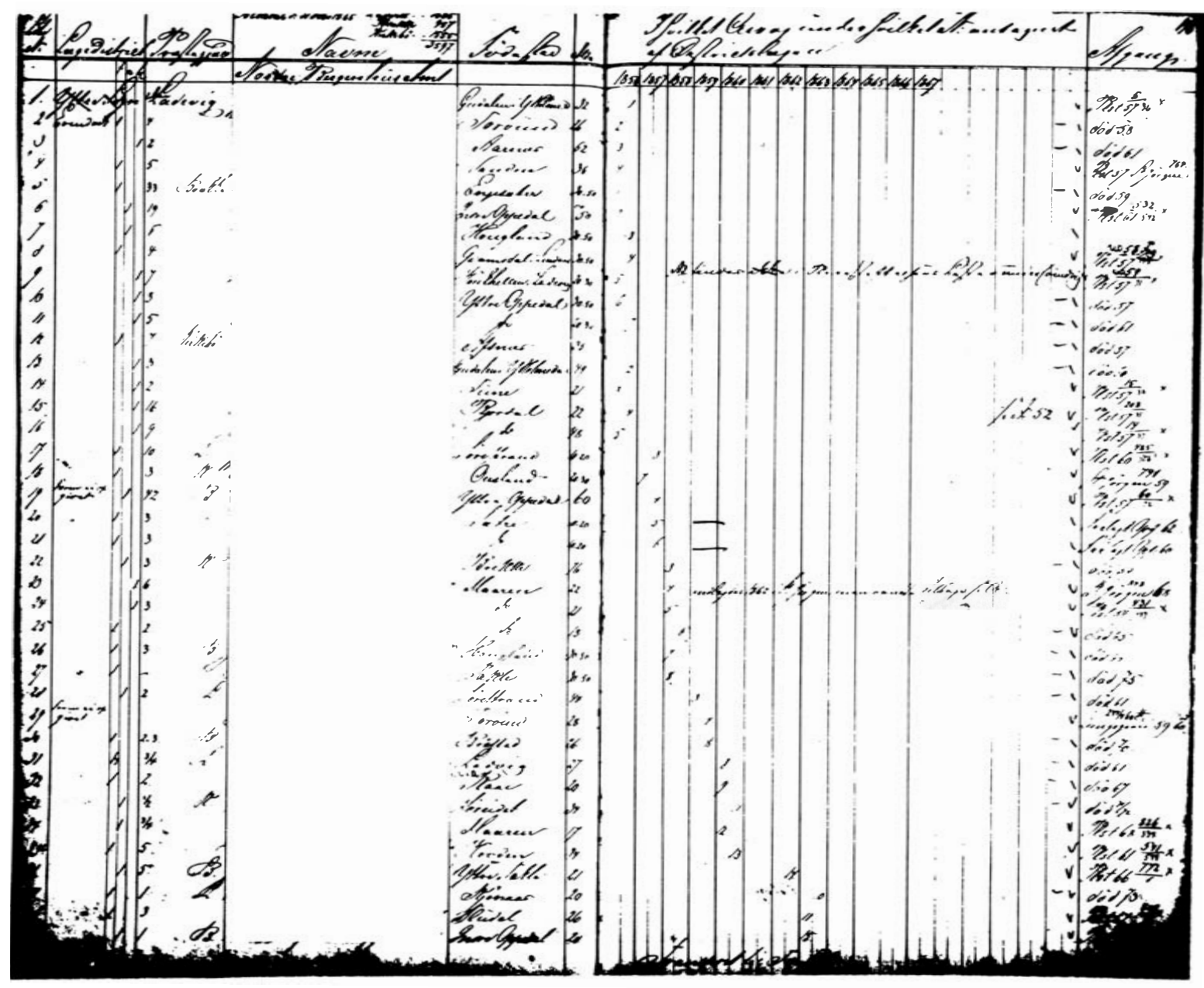

Figure 4. A page from a district register book. (The National Leprosy Registry of Norway.) 


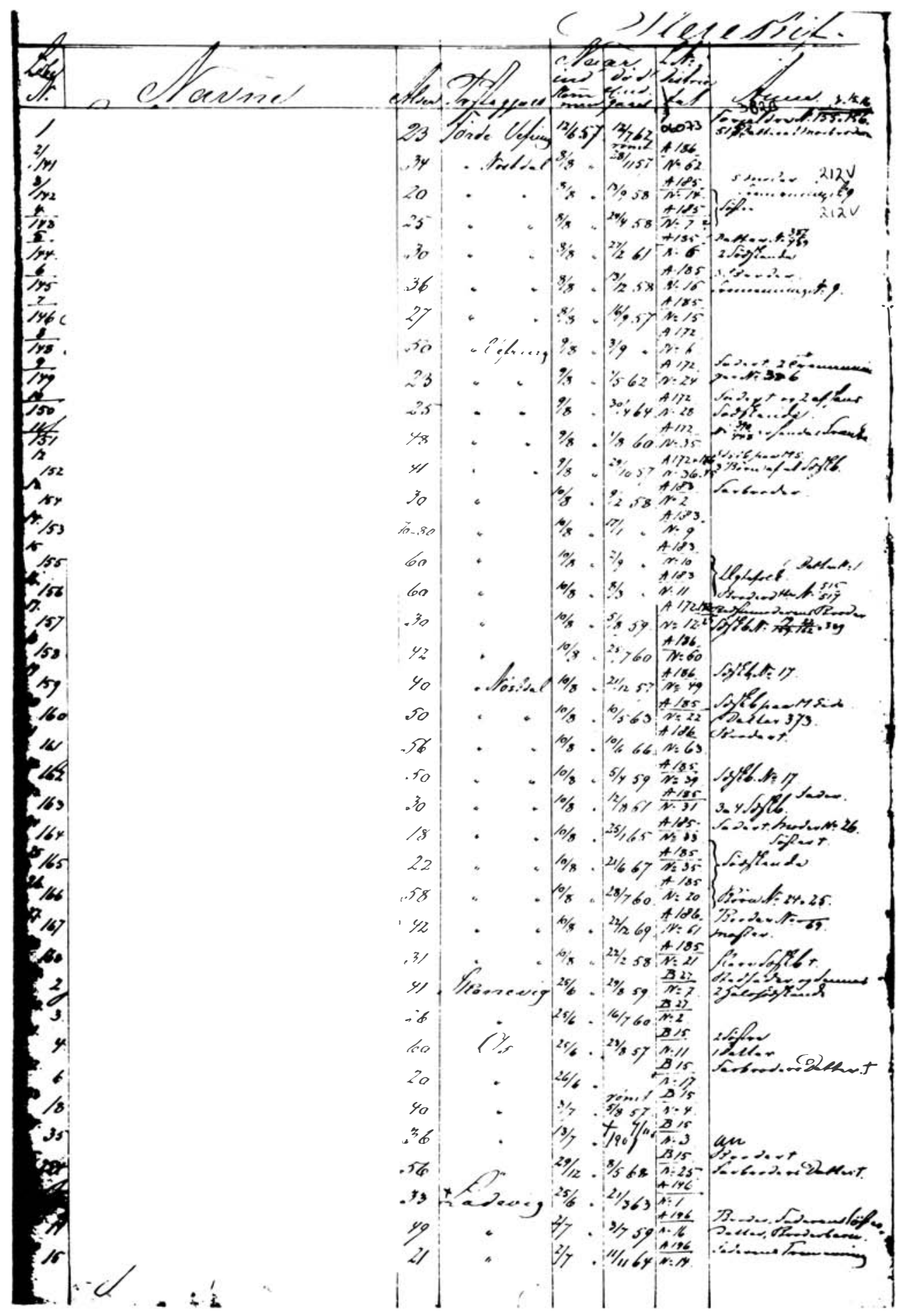

Figure 5. A page from a hospital register book. (The National Leprosy Registry of Norway.) 
references were included in a patient report to previous reports on the same patient.

The content of the follow up form was entered in a separate column for additional information on the same line at the end of the patient report (Fig. 4).

\section{Hospital register}

The heads of the 5 leprosy hospitals (Irgens, 1973) annually forwarded information to the central office on all admissions and discharges. Apparently, no structured form was used. The information was entered into the handwritten books of the hospital register. The pages were structured with separate columns for the different items of data (Fig. 5, Table 1). Each patient report was identified by a particular hospital serial number allotted consecutively according to the date of admission. Each report was entered on a separate line, and each page contained reports from only one hospital. To a considerable extent district serial numbers of the patients were included in the reports.

\section{Hospital patient records}

The patient records of the leprosy hospitals represented a source of data in addition to the files of the Leprosy Registry. The records were kept in handwritten books, mostly unstructured, and were identified by the hospital serial number. The books were sent to the central office when the hospitals were gradually closed down.

\subsubsection{PROCEDURE OF COMPUTERIZATION}

The transfer of data was divided into separate steps; viz. choice of material, organization of patient records, technical transfer, identification of information, checking and completion, and search for doublet records.

\section{Choice of material}

Transfer of the total material appeared impossible due to the multitude of the sources. The criteria for the choice of material were related to the content of the different items and the form of their representation in the books.

The demands on content were defined without taking into consideration particular working hypotheses which might be of interest in the initial stages of the investigation. The intension was to transfer as much as possible of all information relevant to the epidemiology of leprosy. Thus hypotheses derived in the analytical stages of the investigation also might be tested.

The demands on form of representatation had to be carefully considered when a computer file comprising more than 8,000 patients was to be established, 
Table 1. Items of personal data used in the district register and the hospital register. (The National Leprosy Registry of Norway)

\begin{tabular}{ll}
\hline \multicolumn{1}{c}{ District register } & \multicolumn{1}{c}{ Items of personal data } \\
\hline Serial number, district & Serial number, hospital \\
Name & Serial number, district \\
Residential district & Name \\
Birthplace & Residential district \\
Age when registered & Age when admitted \\
Duration of disease when registered & Duration of disease when admitted \\
Type of leprosy & Type of leprosy \\
Relatives with leprosy & Relatives with leprosy \\
Year of registration & Date of: \\
Eventual year of: & admission \\
admission to hospital & discharge \\
and what hospital & Conclusion: \\
migration & dead \\
and to what district & cured \\
cure & 'erroneous' primary diagnosis \\
correction of diagnosis & deserted \\
death & expelled \\
\hline
\end{tabular}

linking together data from different sources to one patient record. To reduce the amount of work, only items which were given a representation easy to interpret and transform, where chosen. Furthermore, items which had not been entered in a standardized way into structured parts of the books with the application of a standardized and precise nomenclature were omitted.

Almost all items in the district register and the hospital register (Table 1) satisfied these demands and were transferred to the computer file. Since most of the information in the report forms had been transferred to the district register, the forms per se were not used as a source of data. The hospital patient records, however, were organized in a way which made a comprehensive transfer of the material impossible.

\section{Organization of patient records and technical transfer}

All information on each patient was assembled and transferred to one record, the patient record. The content of this patient record was defined by the choice of material. The structure of the patient record is to some extent related to the structure of the patient reports in the two registers (Table 2). The four main parts of the patient record consist of the patients' basic data, data from the district register, data on relatives with leprosy and data from the hospital register.

The data were transferred by punch cards containing one patient report per card. Direct punching was used for all data except for data on relatives affected by leprosy. 
Table 2. Layout of the patient record in the computer file. (The National Leprosy Registry of Norway.)

\begin{tabular}{|c|c|c|c|c|}
\hline $\begin{array}{l}\text { Field } \\
\text { No. } \\
\end{array}$ & $\begin{array}{l}\text { Position } \\
\text { From }\end{array}$ & $\begin{array}{l}\text { No. of } \\
\text { Positions }\end{array}$ & Contents & Card \\
\hline 01 & 01 & 1 & $\operatorname{Sex}$ & 1 \\
\hline 02 & 02 & 5 & Identification no. & 1 \\
\hline 03 & 07 & 31 & Name & $1,(3)$ \\
\hline 04 & 38 & 4 & Occupation & \\
\hline 05 & 42 & 1 & Diagnosis correct/incorrect & \\
\hline 06 & 43 & 5 & Birthplace & 1 \\
\hline 07 & 48 & 8 & Birthyear & 1,3 \\
\hline 08 & 56 & 4 & Year of onset & 1,3 \\
\hline 09 & 60 & 4 & Review of family & 1 \\
\hline 10 & 64 & 4 & Year of death & 1,3 \\
\hline 11 & 68 & 19 & First registration & 1 \\
\hline 1) & 68 & 4 & Registration year & 1 \\
\hline 2) & 72 & 5 & Registration district & 1 \\
\hline 3) & 77 & $1^{\bullet}$ & Type of leprosy & 1 \\
\hline 4) & 78 & 1 & Later information (migrated, cured, etc) & 1 \\
\hline 5) & 79 & 4 & Year & 1 \\
\hline 6) & 83 & 4 & Place & 1 \\
\hline 12 & 87 & 19 & Second registration & 1 \\
\hline 13 & 106 & 19 & Third registration & 1 \\
\hline 14 & 125 & 19 & Fourth registration & 1 \\
\hline 15 & 144 & 18 & Family information ( 9 relatives) & 2 \\
\hline 1) & 144 & 9 & First relative & 2 \\
\hline (1) & 144 & 2. & Characterization (brother, father, etc) & 2 \\
\hline$(2)$ & 146 & $7^{\circ}$ & Identification no. & 2 \\
\hline 16 & 225 & 33 & First admission to hospital & 3 \\
\hline 1) & 225 & 1 & Hospital & 3 \\
\hline 2) & 226 & 9 & Hospital serial no. & 3 \\
\hline 3) & 235 & 5 & District admitted from & 3 \\
\hline 4) & 240 & 1 & Hospital admitted from & 3 \\
\hline 5) & 241 & 7 & Date of admission & 3 \\
\hline 6) & 248 & 7 & Date of discharge & 3 \\
\hline 7) & 255 & 1 & State when discharged (cured, dead, etc) & 3 \\
\hline 8) & 256 & 1 & Discharged to another hospital & 3 \\
\hline 9) & 257 & 1 & Type of leprosy & 3 \\
\hline 17 & 258 & 33 & Second admission to hospital & 3 \\
\hline 18 & 291 & 33 & Third admission to hospital & 3 \\
\hline 19 & 324 & 33 & Fourth admission to hospital & 3 \\
\hline
\end{tabular}

Sets of codes were prepared for the direct punching of qualitative observations. The sets were applied by the punch operator for coding during the punching process.

Data on relatives with leprosy were transferred by a set of codes difficult to 
apply during punching. The data had to be coded into a special form which served as a basis for punching.

\section{Identification of patient reports and patient records}

The utilization of the material in a longitudinal epidemiological study called for the introduction of an unambiguous system of identification, important to the technical transfer of data. Accordingly, a superior identification number was introduced. Each patient record was identified by its identification number, and a computer catalogue was established, linking all district serial numbers of a patient to his identification number.

The new identification number was introduced during punching of data from the patient reports in the district register. All patient reports which lacked a cross reference to a previous report in the district register, were given a new identification number. The remaining patient reports were identified by the identification number already allotted when previous reports were punched. The identification number was used for the linkage of data from different patient reports in the district register into the appropriate patient records.

The patient reports in the hospital register were identified during punching by one of the district serial numbers present in most of the reports. Together with the computer catalogue, these district serial numbers made a correct identification and linkage possible. The correct identification number for the reports in the hospital register which lacked a cross reference to a district serial number, had to be found manually in an alphabetical listing of all patient records established in the computer file. Some patients were reported only to the hospital register and never to the district register. In such cases a patient record was established on the basis of the patient report in the hospital register and a new identification number was allotted.

Information contained in a patient report on a relative with leprosy, was identified during coding by the district serial number of the patient and was entered into his patient record by the catalogue. Also the district serial number of the relative was entered into his patient record (Table 2, pos. 144-).

\section{Checking and completion of data}

To find and correct possible errors, all patient reports were listed, and invalid codes were indicated. The lists were proof-read against the original sources up to three times.

The content of the patient records was tested by a programme introducing fixed limits for all quantitative variables. Also relative limits for these variables were used to check the consistency of the information kept in one patient record.

Furthermore, the three relatively independent sources of data were used to compile a computer file as accurate, reliable and complete as possible. To a 
considerable extent the patient reports in both registers contain basic personal data about the patients (Table 1). When data were transferred from a patient report to a patient record in the computer file, the consistency between the basic data possibly already present in the record and those in the patient report was checked by the computer. In a case of inconsistency, and provided linkage was correct, the third source of data, the hospital patient records, were considered to give the correct information.

In spite of establishing the patient record on the basis of several patient reports from the two registers, complete records for all cases were not obtained. To complete as far as possible the patient records with respect to basic items of personal data, all incomplete records were listed, and the hospital patient records were used for completion.

The computer was used for the completion of the patient records with respect to information on relatives with leprosy (Table 2). It appeared that patient $\mathrm{B}$ was often referred to as a relative in the record of patient $\mathrm{A}$, while information in B's record on A as a relative was lacking. A computer programme was used to establish mutual cross references.

\section{Search for doublet records}

Due to lack of complete references within and between the two registers, more than one record per patient might be established in some cases. The deletion of such doublet records was postponed until punching was finished and the computer file was established. Accordingly, the computer could be used in search for doublet records.

A search was first performed using the items: sex, residential district, registration year and name as criteria. The patient records were listed according to the items. This search ensured that patient records resulting from more than one report on a patient from one particular district were listed not far from each other. By looking through the lists, doublet records of this kind were easily detected.

To detect doublet records for a patient based on reports from different districts, another search was carried out on the basis of sex and Christian name ${ }^{1}$ only.

All doublet records detected were deleted, and the data were transferred to the appropriate patient records where space for data from additional reports was provided (Table 2 ).

\footnotetext{
${ }^{1}$ In Norway in the past, the Christian name was more firmly attached to a person than the surname, which usually was the name of the farm.
} 
Table 3. Total number of cases and reports registered in the district register and the hospital register, by number of reports per case. (The National Leprosy Registry of Norway.)

\begin{tabular}{lrrrrr}
\hline $\begin{array}{l}\text { Number of } \\
\text { reports }\end{array}$ & \multicolumn{2}{c}{ District register } & & \multicolumn{2}{c}{ Hospital register } \\
\cline { 2 - 3 } \cline { 5 - 6 } per case & Cases & Reports & & Cases & Reports \\
\hline 1 & 7,140 & 7,140 & & 4,091 & 4,091 \\
2 & 751 & 1,502 & & 628 & 1,256 \\
3 & 65 & 195 & & 114 & 342 \\
4 & 11 & 44 & & 33 & 132 \\
\hline Subtotal & 7,967 & 8,881 & & 4,866 & 5,821 \\
0 & 530 & 0 & & 3,631 & 0 \\
\hline Total & 8,497 & 8,881 & 8,497 & 5,821 \\
\hline
\end{tabular}

\subsubsection{RESULTS}

Data from 14,702 patient reports were transferred; 8,881 from the district register and 5,821 from the hospital register (Table 3).

Of 8,881 patient reports in the district register, 7,967 represented the first report on a patient and formed the basis of 7,967 patient records. The additional 914 reports represented new information on already registered patients, forwarded to the central office by the main form. The reports represented 827 second notifications, 76 third notifications and 11 fourth notifications. Data from the additional reports were transferred to the appropriate records where space was reserved.

Of 5,821 patient reports in the hospital register, 4,866 represented the first admission of a patient. The additional 955 reports represented 775 second admissions, 147 third admissions and 33 fourth admissions. Linkage of these data to the appropriate patient records was performed by the computer for 3,524 reports which contained a district serial number. Correct identification numbers for 2,297 reports which lacked a cross reference to a district serial number, had to be found manually. For 530 hospital patients no patient report could be found in the district register. Apparently, these patients had been sent directly to the hospital without being notified in a main form, and remained in hospital until they died. These reports in the hospital register formed the basis for another 530 patient records.

Thus, a total of 8,497 patient records was established. Of these, 266 records contained information that invalidated the diagnosis. Accordingly, the computer file contains a total of 8,231 patient records (Table 6).

To establish the computer file $1,372.5 \mathrm{~h}$ were used for punching and control punching while $287 \mathrm{~h}$ were used for programming. Time used for planning and for manual procedures including proof-reading, was not registered. 


\subsubsection{COMMENTS}

During the transfer of data from the original sources to the computer file, it became evident that the practical management of the registry has been well organized and accomplished. This is remarkable, taking into consideration that the registry was established in the middle of the last century in a country where communications were seriously impeded by a rugged landscape. Apparently, this is also the reason why it was possible to establish a complete computer version; the sources available turned out to cover the entire country and the whole period of observation, containing almost complete information on all cases registered.

In the choice of material, the intention, to establish a file on all leprosy cases as reliable, accurate and complete as possible, had to be considered against the practical problems. Almost all data from the two coordinate registers could easily be transferred. However, a complete transfer of the material of the hospital patient records would involve an amount of work far more extensive than for the two registers, in part due to the magnitude of the material, but particularly because of its structure and form. Consequently, the data in the hospital patient records were used only for limited purposes.

Most of the data found in the register books had a form compatible with direct punching. Accordingly, a most time-consuming work was avoided; viz. coding data onto a special form, and thus introducing a new source of error. On the other hand, the punching itself became more time consuming and gave a higher frequency of errors than punching based on special forms. Furthermore, the data had to be proof-read most carefully.

Obtaining an unambiguous system of identification, necessary to bring together data in appropriate patient records, represented the most important, but also the most difficult part of the computerization, and called for the introduction of a new superior identification number. The alternative, to choose one of the district serial numbers as a superior number, was considered inconvenient; in part because no superior number was stated in the original sources, in part because the cross references were far from complete.

Appropriate identification numbers were not allotted to the patient reports before punching. Accordingly, lacking cross references to previous reports would inevitably produce doublet records. The solution of this important problem was postponed, however, with the assumption that the computer might assist in the search for doublet records, which proved correct. The alternative, manual search for and control of all identification numbers before punching would, if accomplishable, require a vast amount of work.

To evaluate the computerization and particularly the method of identification, the total number of patient records was compared with The official statistics of Norway (Melsom, 1948). The official statistics are based on the patient reports in the district register and hospital register. It is stated that 8,218 cases have been registered from 1856 until 1945, which, in addition to 4 
cases later registered, total 8,222 cases. Compared with the 8,231 patient records in the computer file, the difference amounts to 9 cases or $0 \cdot 1 \%$.

In this comparison of statistics based on the computerized material with those based on conventional processing of the original sources, possible lack of correspondence might either be due to errors in the manual procedure or in the computerization. Obviously, the manual procedure was associated with risks of simple miscalculations. Furthermore, the lack of complete cross references introduced a risk that one patient might be counted more than once. Still the official statistics are considered reliable. It is of particular importance that the clerks at the central office were closer to the practical problems and perhaps knew the patients individually. They most probably had information exceeding that written in the books. Accordingly, for practical purposes the total number of cases conventionally compiled is considered the correct number:

Errors related to the computerization would be of two kinds. On one hand, some part of the material may not have been found, or possibly some patient reports may have been overlooked during punching. However, the reports were entered into books, and books were found covering the entire country throughout the whole period of observation. Transfer of every report was secured through proof-reading. Consequently, this source of error is considered insignificant.

On the other hand, some patients might still be represented in the file by two or more patient records, possibly due to a failure in the system of identification established. Since the importance of the other possible sources of error is considered insignificant, the comparison of the two totals may serve as an evaluation of the system of identification. On this basis the result, a difference of 9 cases or $0 \cdot 1 \%$, is considered acceptable.

\subsection{Evaluation of the material}

The files of the registry, established 120 years prior to the present study and mostly for other purposes (Irgens and Bjerkedal, 1973) had to be examined carefully with respect to their usefulness as a basis for epidemiological studies. Qualitative and quantitative aspects had to be taken into account; the evaluation was focused on what has been registered on whom.

On one hand the intention was to state whether the pathological condition described as leprosy in Norway, truly represented leprosy, as the disease is known today, and if so, whether there was a correspondence between systems of classification applied at that time and today. Furthermore, the content of each patient record was to be evaluated.

On the other hand the intention was to assess to what extent all persons in Norway affected by leprosy and living after 1856, were represented by a patient record in the computer file, and to what extent all patient records in this file truly represented leprosy patients. 


\subsubsection{MATERIAL USED IN THE EVALUATION}

In the abundant literature on leprosy in Norway some attention has been paid to the registration of cases, but only to its basis, the Royal Decree of 1856, and the outcome of it, The Official Statistics. Thus, the files of the central office have never previously been considered a central patient registry for the entire country.

Accordingly, the evaluation was first of all based on the files of the central office where, in addition to the register books, all patient forms were found together with circulars and instructions for the District Health Officers. Furthermore, an extensive correspondence on the patients was filed. The official regulations concerning leprosy control in general and the registration work in particular, were also considered.

The evaluation was also based on relevant scientific literature. Of particular importance was a monograph published by DC Danielssen \& CW Boeck (1847); the result of a research programme initiated by the health authorities in the 1830s. The initiative was related to a census of leprosy patients in 1836 which demonstrated a great uncertainty in distinguishing leprosy from other diseases. The monograph soon obtained a high reputation internationally and dominated the small medical profession in Norway.

The tradition established by Danielssen \& Boeck was continued by $\mathrm{G} \mathrm{H}$ Armauer Hansen \& C Looft (1895) who published a textbook: 'Leprosy in its Clinical and Pathological Aspects'.

A comparison with the view on leprosy of today was based on the textbook by R G Cochrane \& T F Davey (1964) and the system of classification introduced by D S Ridley \& W H Jopling (1966).

Information from the nominative population censuses in 1865 and 1875 was used as an independent source of data to assess the reliability of the information reported from the districts on patients living in their homes by 1865 and 1875 respectively. Furthermore, genealogies of high frequency districts, sometimes stating that a member of a family was affected by leprosy, were used to assess certain aspects of the validity.

\subsubsection{PROCEDURE OF EVALUATION}

The evaluation was divided into two steps. First, the files of the central office were studied in the original form together with the additional material mentioned, focusing on organizational and administrative aspects of the registry. These aspects, it was assumed, were closely related to the possible usefulness of the material in epidemiological studies. From the same point of view, it was necessary to clarify the criteria for the diagnosis of leprosy applied in registration work. A basis of information had to be obtained, making it possible to decide whether the criteria defined a nosological entity equal to leprosy as it is known today and, if possible, whether there is correspondence between systems 
of classification used at that time and today. In addition to the evaluation of the material itself, the first step was performed to decide whether a computerization seemed justified.

Secondly, the computer file made an evaluation possible based on the data registered. This step concentrated on the validity of the registration work, assessing on one hand the extent to which all patients registered truly represented leprosy, and on the other, the extent to which all patients affected by leprosy were registered. Furthermore, the computer file was used to assess completeness and reliability of the data registered.

\subsubsection{RESULTS}

The foundation and general management of the Leprosy Registry have been related previously (Irgens and Bjerkedal, 1973). Here, special attention will be given to aspects pertaining to epidemiological use of the material.

\section{Organization}

By the Royal Decree of 1856 the registration work became the responsibility of the public health authorities. At the same time definite instructions were given on how registration should be carried out in the districts and how the information should be forwarded to the central office. However, the Royal Decree gave no instructions on how the work should be organized at the central office. Neither has the literature dealing with official leprosy statistics given any information on central registration work. Accordingly, the existence of a central national patient registry for leprosy was first evident after the examination of the instructions together with forms and register books found in the files of the central office.

For the hospital register, neither an administrative basis of registration nor a system for forwarding information to the central office has been mentioned in the literature. The hospital register appeared to be complete with respect to admissions and discharges from 1861. It is assumed that the register was established the same year, together with the opening of the last hospital built during the anti-leprosy programme of the Government (Irgens, 1973). Still, much information on earlier admissions is kept in the hospital register, apparently based on information from hospital patient records.

Administration of the registration work was entrusted to the Chief Medical Officer for Leprosy (Irgens, 1973) who was a leader of the central registration work and a supervisor of the work in the districts.

Forms, instructions and circulars filed at the central office add to the documentation that the management of the registry was well organized, and so do numerous annual reports from the central office, accounting for the registration work in the districts and its aims (Irgens and Bjerkedal, 1973). 


\section{Case finding}

Compulsory notification of all cases of leprosy was the responsibility of the District Health Officers, each in charge of a population of up to 10,000 inhabitants. Case finding involved more than notifying patients who consulted the doctor. The doctor was to give information as accurate as possible on all leprosy patients living in his district.

Therefore, the District Health Officers were assisted by local Boards of Health, established in all districts where leprosy was found, and instrumental in the notification of all cases. The annual reports from the central office show that the cooperation with the local Boards of Health was effective.

According to the Royal Decree the doctors were also assisted by the ministers of the church who served parishes which were smaller than the districts of the health officers. The ministers had, for a long time, been entrusted to register all births and deaths in their parishes and were, accordingly, suitable assistants in the registration of leprosy cases.

On his travels through the districts, The Chief Medical Officer examined a number of patients himself to verify the diagnosis with respect to disease and classification and to supervise the health officers in the registration work.

\section{Follow up}

One of the aims of the registration work, viz. putient care, rendered follow-up information necessary. Instructions were given that all major changes in the patients should be reported by the local doctors. Important follow-up information was also forwarded from the leprosy hospitals, and this type of data amounts to a considerable part of all data registered.

The follow-up information formed the basis for a special classification of the cases.

Definite cases were cases in which the diagnosis was certain. These patients were all followed until they died.

Evanescent cases were patients who were cured after some time without relapse. Also the course of these patients has been followed carefully until the final conclusion of cure could be made.

Erroneous cases were patients who, after careful follow-up examinations, proved not to be affected by leprosy. Like evanescent cases these cases were followed until the final statement could be given.

Routines of notification, including methods of case finding and follow up, underwent remarkably few changes from 1856 until 1957 when the post of the Chief Medical Officer was discontinued. During the whole period, the field work was the responsibility of the District Health Officers directed and aided by the Chief Medical Officer. 


\section{Diagnostic criteria}

Based on comprehensive clinical and pathological studies, Danielssen and Boeck (1847) introduced definite criteria to distinguish leprosy from other diseases. Differential diagnoses were broadly discussed.

The disease was divided into two forms, the tuberculous and the anaesthetic. It was also stated that type of leprosy might change in a patient over time (p. 214). Furthermore, many cases could not be classified as one of the polar forms. They were considered to represent a continuum between the two polar forms (p. 247). Thus the dynamics found in the classification of today were introduced. The authors had also observed acute relapses, apparently related to cursive nodosum leprosum, which were described in detail (p. 152).

Without great changes, the diagnostic principles of Danielssen \& Boeck were applied by Hansen \& Looft (1895), who introduced the terms tuberous and maculo-anaesthetic for the two polar forms. Also intermediate cases were described. However, the dichotomy in the classification was stressed. The intermediate manifestations were interpreted as a result of a transformation of a case from one type to another (p. 3). This transformation, argued Hansen and Looft, justified retaining only two classes (p. 3). However, a third mixed form was still used to some extent for classification of cases in the Leprosy Registry as well as in clinical work (vide 2.5.3.)

The morphological descriptions of the maculo-anaesthetic form, given by Hansen \& Looft (1895, p. 55) and other Norwegian leprologists (Looft, 1891; Lie, 1912; Lie, 1923; Lie, 1927) leave no doubt that pure tuberculoid cases occurred in Norway, classified as maculo-anaesthetic.

The criteria of diagnosis and classification were applied by a small and homogeneous profession, considering leprosy an important public health problem. Almost all doctors graduated from the medical school at the only university in the country. The students were, until the 1940's, sent to the main leprosy hospital to obtain the best teaching and training arranged by the Chief Medical Officer and based on the national scientific tradition.

On the basis of clinical and pathological criteria, the classification used in Norway was compared with a system of classification of widespread and increasing use today introduced by Ridley \& Jopling (1966) (Table 4). It seems to be generally recognized that the essence of the tuberculoid-lepromatous classification is the 'resistance' of the patient to his infection. Accordingly, to classify a case, the resistance of the patient should be assessed in some way. This was difficult in the present material. However, the clinical and pathological description of the diagnostic groups corresponds well with the criteria used for classification in Norway. To the extent that an association exists between resistance on one hand and sign and symptoms on the other, E. tuberculosa or L. tuberosa would have apparently been classified today as LL or BL, E. tuberculoanaesthetica or L. mixta as $\mathrm{BL}, \mathrm{BB}$ or $\mathrm{BT}$ while E. anaesthetica or L. maculoanaesthetica would have been classified as BT or TT (Table 4). 
Table 4. Equivalent terms used in diagnosis of leprosy by The National Leprosy Registry of Norway and today.

\begin{tabular}{|c|c|c|}
\hline \multicolumn{3}{|c|}{ Equivalent terms used } \\
\hline \multicolumn{2}{|c|}{ by The National Leprosy Registry of Norway } & today \\
\hline $\begin{array}{l}\text { Danielsson \& Boeck } \\
(1847)\end{array}$ & $\begin{array}{c}\text { Hansen \& Looft } \\
(1895)\end{array}$ & $\begin{array}{c}\text { Ridley \& Jopling } \\
\text { (1966) }\end{array}$ \\
\hline Elephantiasis (E.) & Lepra (L) & Leprosy \\
\hline E. tuberculosa & L. tuberosa & LL BL \\
\hline E. tuberculo-anaesthetica & L. mixta & $\mathrm{BL}$ BB BT \\
\hline B. anaesthetica & L. maculo-anaesthetica & BT TT \\
\hline
\end{tabular}

\section{Validity}

Obviously, no complete independent source of data was available to evaluate the sensitivity of the Leprosy Registry as a diagnostic procedure applied to the population. Such data were necessary to assess under-registration, due to overlooked or false negative cases. However, all patients detected by chance in general nominative censuses or in local genealogies and all persons with leprosy inquired after by descendants today, are represented by patient records in the computer file.

On the basis of the computer file the extent of under-registration was assessed indirectly. Possible delays in registration work with long periods between onset of the disease and registration, might cause insufficient case finding and under-registration, e.g. due to death before registration. However, the duration of the period between onset and registration was short; the median was 1.4 years for all patients with year of onset between 1856 and 1970 (Table 5).

Spontaneous cure before registration might represent a similar cause of under-registration. In the computer file 183 patients were reported cured without relapse, but the material gave no indication that all cured cases were notified.

However, the data made an appraisal possible of whether the administration of the registry itself considered the registration work satisfactory. The demonstration by Hansen of the leprosy bacillus in 1873, gave strong support to the view that leprosy was a contagious disease. Accordingly, immediate isolation of the cases was considered an effective control measure and was introduced in the legislation against the disease (Irgens, 1973). The demands on accurate and efficient registration work were strengthened. However, greater efforts were apparently not required; the duration of the period between onset and registration did not decrease after 1873 (Table 5).

The extent of over-registration, i.e. diagnoses of leprosy in persons not affected by the disease, could be assessed more thoroughly. A total of 8,497 persons were notified as leprosy patients during the period 1856-1970. 
Table 5. New cases of leprosy in Norway with median and semi-interquartile range of the delay period between onset and registration, by year of onset. (The National Leprosy Registry of Norway)

\begin{tabular}{cccc}
\hline \multirow{2}{*}{$\begin{array}{c}\text { Year } \\
\text { of } \\
\text { onset }\end{array}$} & $\begin{array}{c}\text { Number } \\
\text { of } \\
\text { patients }\end{array}$ & $\begin{array}{c}\text { Median } \\
\text { (years) }\end{array}$ & $\begin{array}{c}\text { Semi-interquartile range } \\
\text { (years) }\end{array}$ \\
\hline $1856-1860$ & 1,154 & $1 \cdot 3$ & $1 \cdot 1$ \\
$1861-1870$ & 2,005 & $1 \cdot 2$ & $1 \cdot 1$ \\
$1871-1880$ & 1,241 & $1 \cdot 6$ & $1 \cdot 5$ \\
$1881-1890$ & 615 & $1 \cdot 6$ & $1 \cdot 5$ \\
$1891-1900$ & 276 & $2 \cdot 0$ & $1 \cdot 9$ \\
$1901-1910$ & 117 & $1 \cdot 7$ & $1 \cdot 7$ \\
$1911-1920$ & 43 & $1 \cdot 6$ & $1 \cdot 7$ \\
$1921-1970$ & 14 & $2 \cdot 0$ & $1 \cdot 7$ \\
\hline $1856-1970$ & 5,465 & $1 \cdot 4$ & \\
\hline-1855 & 2,289 & & \\
Unknown & 477 & & \\
\hline Total & 8,231 & & \\
\hline
\end{tabular}

Supplementary information revealed that 266 persons had never been affected. Provided these persons can be interpreted as representing the false positive cases, produced by the diagnostic procedure applied on the population by the Leprosy Registry, the predictive value of a primary diagnosis can be calculated. Predictive value, expressed as the percentage of correct diagnoses, was for the whole period $96.9 \%$, increasing from $95.9 \%$ in 1856 up to $100 \%$ between 1911 and 1970 (Table 6).

The demonstration of false diagnoses in 266 persons did not preclude the existence of further false diagnoses among the remaining 8,231 patients. The magnitude of this number was assessed from information in the hospital register. A diagnosis made in hospital was considered more reliable than a diagnosis made by a local doctor. Of all 8,497 persons notified, 4,866 (57.3\%) were admitted to hospital once or more, and the diagnosis was confirmed in 4,807 cases, corresponding to a predictive value of $98 \cdot 8 \%$ (Table 7). Among the 4,807 patients with a confirmed diagnosis, the number of false positive cases is considered insignificant. For the patients not admitted to hospital the diagnosis was confirmed in 3,424 of 3,631 cases; i.e. a predictive value of $94.3 \%$. This lower value reflects effort in follow up and detection of false diagnoses. For this reason the remaining number of false diagnoses among patients not admitted to hospital may be considered low.

\section{Completeness}

Of the 8,231 records representing patients with leprosy, 7,515 (91.3\%) were complete with respect to name, sex, residential district, years of birth, onset 
Table 6. New cases by year of registration and correctness of diagnosis with respect to disease. (The National Leprosy Registry of Norway)

\begin{tabular}{ccccc}
\hline \multirow{2}{*}{$\begin{array}{c}\text { Year } \\
\text { of } \\
\text { registration }\end{array}$} & Total & $\begin{array}{c}\text { Correct } \\
\text { diagnosis } \\
\text { Number }(2)\end{array}$ & $\begin{array}{c}\text { Incorrect } \\
\text { diagnosis } \\
\text { Number }(3)\end{array}$ & $\begin{array}{c}\text { Predictive } \\
\text { value of diagnosis } \\
((2) /(1) \times 100)\end{array}$ \\
\hline 1856 & 2,095 & 2,009 & 86 & $95 \cdot 9$ \\
$1857-1860$ & 1,080 & 1,037 & 43 & $96 \cdot 0$ \\
$1861-1870$ & 2,246 & 2,180 & 66 & $97 \cdot 0$ \\
$1871-1880$ & 1,531 & 1,489 & 42 & $97 \cdot 2$ \\
$1881-1890$ & 801 & 786 & 15 & $98 \cdot 1$ \\
$1891-1900$ & 422 & 411 & 11 & $97 \cdot 4$ \\
$1901-1910$ & 223 & 220 & 3 & $100 \cdot 7$ \\
$1911-1920$ & 72 & 72 & 0 & $100 \cdot 0$ \\
$1921-1970$ & 27 & 27 & 0 & $96 \cdot 9$ \\
\hline Total & 8,497 & 8,231 & 266 & \\
\hline
\end{tabular}

Table 7. Cases registered by correctness of diagnosis with respect to disease, according to whether admitted to hospital or not. (The National Leprosy Registry of Norway)

\begin{tabular}{ccccc}
\hline & \multicolumn{4}{c}{ Cases primarily diagnosed as leprosy } \\
\cline { 2 - 5 } $\begin{array}{c}\text { Admission } \\
\text { to hospital }\end{array}$ & Total & $\begin{array}{c}\text { Correct } \\
\text { diagnosis } \\
\text { Number }(2)\end{array}$ & $\begin{array}{c}\text { Incorrect } \\
\text { diagnosis } \\
\text { Number }(3)\end{array}$ & $\begin{array}{c}\text { Predictive } \\
\text { value of diagnosis } \\
((2) /(1) \times 100)\end{array}$ \\
\hline $\begin{array}{c}\text { Admitted } \\
\text { Not } \\
\text { admitted }\end{array}$ & 4,866 & 4,807 & 59 & $98 \cdot 8$ \\
\hline Total & 3,631 & 3,424 & 207 & $94 \cdot 3$ \\
\hline
\end{tabular}

Table 8. Completeness of data with respect to year of birth, year of onset, register conclusion and type, of all leprosy patients registered. (The National Leprosy Registry of Norway)

\begin{tabular}{|c|c|c|c|c|c|c|}
\hline \multirow[b]{3}{*}{ Completeness $^{\dagger}$} & & & \multicolumn{4}{|c|}{ Type of the disease } \\
\hline & \multicolumn{2}{|c|}{ Total } & \multicolumn{2}{|c|}{ Stated } & \multicolumn{2}{|c|}{ Omitted } \\
\hline & No. & $\%$ & No. & $\%$ & No. & $\%$ \\
\hline $\mathrm{B}+\mathrm{O}+\mathrm{C}+$ & 7,560 & $91 \cdot 9$ & 7,515 & $91 \cdot 3$ & 45 & $0 \cdot 6$ \\
\hline $\mathrm{B}+\mathrm{O}+\mathrm{C}-$ & 152 & $1 \cdot 8$ & 151 & $1 \cdot 8$ & 1 & 0 \\
\hline $\mathrm{B}+\mathrm{O}-\mathrm{C}+$ & 381 & $4 \cdot 6$ & 287 & $3 \cdot 5$ & 94 & $1 \cdot 1$ \\
\hline $\mathrm{B}-\mathrm{O}+\mathrm{C}+$ & 40 & $0 \cdot 5$ & 39 & $0 \cdot 5$ & 1 & 0 \\
\hline $\begin{array}{c}\mathrm{B}-\mathrm{O}-\mathrm{C}+ \\
\text { Other }\end{array}$ & 86 & $1 \cdot 0$ & 28 & $0 \cdot 3$ & 58 & $0 \cdot 7$ \\
\hline combinations & 12 & $0 \cdot 2$ & 7 & $0 \cdot 1$ & 5 & $0 \cdot 1$ \\
\hline Total & 8,231 & $100 \cdot 0$ & 8,027 & $97 \cdot 5$ & 204 & $2 \cdot 5$ \\
\hline
\end{tabular}

${ }^{\dagger} \mathrm{B}$ : Year of birth, O: Year of onset, C: Conclusion, + : Stated, -: Omitted 
and primary registration, type of leprosy and registry conclusion specified as dead with leprosy, permanent cure, permanent emigration or still alive in 1970 (Table 8). Year of birth is calculated on the basis of information on year of primary registration and age when registered. In $990(12.0 \%)$ of the 7,515 records no exact information on year of birth is held. The exact age of these patients was not reported to the central office; however, an age interval of 10 years covering the exact age was stated. In compiling the data, the middle year of the interval was used as the basis for the tabulations of patients by age.

In the records of the remaining $716(8.7 \%)$ patients, some information is lacking. The item of greatest significance is perhaps registry conclusion, lacking in $164(2 \cdot 0 \%)$ records. Apparently, many of these patients emigrated to the USA and this follow-up information was not entered into the register books. The official statistics on leprosy report 288 emigrated patients up to 1890 without stating whether the emigration was permanent (Hansen and Looft, 1895 , p. 145), while in the computer file only 84 patients are registered as permanently emigrated.

Out of the 164 patients without information on conclusion, 56 were reported to have deserted from hospital, and remarks were made in the books for some patients that they could not be localized in spite of all efforts.

Information on year of onset is lacking in $477(5.8 \%)$ records. Out of these, $243(50.9 \%)$ patients were registered in 1856, the first year of registration. Type of leprosy is lacking in $204(2 \cdot 5 \%)$ records, $136(66 \cdot 6 \%)$ of these being registered in 1856 . In $134(1.6 \%)$ records year of birth is lacking.

Data gathered on members of the patients' family affected by leprosy were not complete. In many cases more detailed information was found in hospital records, and this information was transferred to the computer file.

Completeness of data varied from time to time (Table 9) being particularly low in 1856 and improving greatly to a high level until 1980 when a temporary tendency towards incomplete data occurred. At this time, year of onset was permanently dropped as an item in the primary registration. For all patients registered after 1905, information on year of onset is derived from hospital patient records.

\section{Reliability}

Evaluation of reliability called for comparison between independent sources. The district register and the hospital register were not strictly independent. Nevertheless, the systems of reporting were so separate that a comparison seemed justified. This comparison was performed during the establishment of the patient record, linking together data from several patient reports in the two registers. All discrepancies concerning the patients' basic data, e.g. years of birth, onset and death, found in both registers, were detected by the computer. In only a few cases were real discrepancies documented.

In a sample, a comparison, with information from general population 
Table 9. Completeness of data, expressed as number of patients for whom information on an item was lacking, in percent of all patients registered, by year of registration. (The National Leprosy Registry of Norway)

\begin{tabular}{|c|c|c|c|c|c|c|}
\hline \multirow{3}{*}{$\begin{array}{l}\text { Year of } \\
\text { registration }\end{array}$} & \multicolumn{6}{|c|}{ Lack in registration of } \\
\hline & \multicolumn{2}{|c|}{ Year of birth } & \multicolumn{2}{|c|}{ Year of onset } & \multicolumn{2}{|c|}{ Type of leprosy } \\
\hline & No. & $\%$ & No. & $\%$ & No. & $\%$ \\
\hline 1856 & 47 & $2 \cdot 3$ & 243 & $12 \cdot 1$ & 136 & $6 \cdot 8$ \\
\hline $1857-1860$ & 11 & $1 \cdot 1$ & 34 & $3 \cdot 3$ & 33 & $3 \cdot 2$ \\
\hline $1861-1870$ & 11 & $0 \cdot 5$ & 44 & $2 \cdot 0$ & 24 & $1 \cdot 1$ \\
\hline $1871-1880$ & 7 & $0 \cdot 5$ & 34 & $2 \cdot 3$ & 2 & $0 \cdot 1$ \\
\hline $1881-1890$ & 29 & $3 \cdot 7$ & 34 & $4 \cdot 3$ & 4 & $0 \cdot 5$ \\
\hline $1891-1900$ & 25 & $6 \cdot 1$ & 39 & $9 \cdot 5$ & 4 & $1 \cdot 0$ \\
\hline $1901-1910$ & 4 & $1 \cdot 8$ & 31 & $14 \cdot 1$ & 1 & 0.4 \\
\hline $1911-1920$ & 0 & $0 \cdot 0$ & 13 & $18 \cdot 1$ & 0 & $0 \cdot 0$ \\
\hline $1921-1970$ & 0 & $0 \cdot 0$ & 5 & $18 \cdot 5$ & 0 & 0.0 \\
\hline Total & 134 & $1 \cdot 6$ & 477 & 5.8 & 204 & $2 \cdot 5$ \\
\hline
\end{tabular}

Table 10. Patients admitted to hospital the year of registration or the subsequent year, by year of registration and correctness of diagnosis with respect to the type of disease. (The National Leprosy Registry of Norway)

\begin{tabular}{|c|c|c|c|c|}
\hline \multirow[b]{2}{*}{$\begin{array}{l}\text { Year of } \\
\text { registration }\end{array}$} & \multicolumn{4}{|c|}{$\begin{array}{c}\text { Leprosy patients admitted to hospital the year of registration } \\
\text { or the subsequent year }\end{array}$} \\
\hline & $\begin{array}{c}\text { Total } \\
\text { Number (1) }\end{array}$ & $\begin{array}{c}\text { Correct } \\
\text { diagnosis } \\
\text { Number }(2)\end{array}$ & $\begin{array}{l}\text { Incorrect } \\
\text { diagnosis } \\
\text { Number (3) }\end{array}$ & $\begin{array}{c}\text { Predictive } \\
\text { value of diagnosis } \\
((2) /(1) \times 100)\end{array}$ \\
\hline 1856 & 17 & 13 & 4 & $76 \cdot 5$ \\
\hline $1857-1860$ & 26 & 20 & 6 & $76 \cdot 9$ \\
\hline $1861-1870$ & 341 & 308 & 33 & $90 \cdot 3$ \\
\hline $1871-1880$ & 555 & 503 & 52 & $90 \cdot 6$ \\
\hline $1881-1890$ & 274 & 243 & 31 & $88 \cdot 6$ \\
\hline $1891-1900$ & 104 & 96 & 8 & $92 \cdot 2$ \\
\hline $1901-1910$ & 82 & 68 & 14 & $82 \cdot 9$ \\
\hline $1911-1920$ & 32 & 32 & 0 & $100 \cdot 0$ \\
\hline $1921-1970$ & 16 & 15 & 1 & $93 \cdot 7$ \\
\hline Total & 1,447 & 1,298 & 149 & $89 \cdot 7$ \\
\hline
\end{tabular}

censuses referring to 374 patients, revealed no discrepancies with respect to basic personal data.

Considering the classification in hospital with respect to type of leprosy as correct, the reliability of the classification in the district was assessed. Evidently, type of leprosy in a patient may change with time. However, many patients were admitted to hospital a short time after primary diagnosis and classification were made. It appeared that in this group of patients, apart from those registered in the first five years after 1856, there was a high and stable agreement 
between classification in districts and classification in hospitals (Table 10), indicating a high reliability in field work.

\subsubsection{COMMENTS}

The material made it possible to state that the disease, described and notified as leprosy in Norway, in fact was leprosy as the disease is known today. Well defined criteria were established to distinguish leprosy from other diseases. Furthermore, the classification into types appeared to be closely related to the classification used today. The monographs, even assessed by today's knowledge, represent dissertations of remarkable value (Crawford, 1973), stressing signs and symptoms of great significance in the diagnostics and classification of today. The Chief Medical Officers were closely related to this scientific tradition, even before Hansen, and a scientific basis for the registration work was secured.

Standardization was obtained through the compulsory notification entrusted upon the District Health Officers and regulated by detailed instructions. The doctors had a common professional background and graduated in a period when leprosy was considered an interesting field of research and a challenging public health problem, offering important national implications. The efforts of the Chief Medical Officer, as a central coordinator as well as a practical supervisor in the field, have no doubt contributed to standardization of the registration work. Obviously, the lack of changes in the routines of registration for more than 100 years, had the same effect.

Documentation of a standardized registration was also obtained through the establishment of the computer file. The classification of a case with respect to type of leprosy, performed in districts and hospitals appeared to be most accordant, and so were the other data reported from both districts and hospitals.

The leprosy hospitals were, by the standards of that time, of a high medical quality. The hospitals had their own research centre (Irgens, 1973) and were, through personal contacts, connected with other scientific centres. Accordingly, it was assumed that the data of the hospital registers were most reliable. Since discrepancies between the two registers were detected only in an insignificant number of cases, the reliability of the data in the district register, for patients not admitted to hospital, was also considered satisfactory.

The validity of the registration scheme was apparently greatly influenced by one of the purposes of establishing the registry; to obtain an epidemiological description of the disease. For this reason registration was made compulsory. The subsequent demonstration of leprosy as an infectious disease gave support to the decree. This task was attempted with assistance from the ministers of the church and the local Boards of Health. Presumably, the local Boards of Health played an important part, searching for patients who hid away from the stigmatizing attitudes of the local society. Unfortunate social effects of these activities will not be discussed here. 
Moreover, individual follow up of the patients contributed to the validity of the registration scheme. On one hand, false positive cases were detected and deleted in the books. On the other hand, follow up work in the district led to a closer contact between the doctor and the population. The contact was also valuable in the search for new cases, and of great importance to avoid underregistration. In particular, the routines of current follow up made the calculation of incidence rates far more reliable than rates based on mere patient censuses repeated at intervals.

However, data directly related to validity were only available to a minor extent. In particular, the magnitude of under-registration was difficult to assess. Still, the length of time between onset of the disease and registration gave some indication, and a median no longer than 1.4 years was considered the result of effective efforts in case finding.

Apparently, over-registration, giving a low predictive value of the primary diagnosis, only occurred infrequently. However, information on all erroneous cases might not have been forwarded to the central office. If a doctor felt uncertain, he might have observed the patient for some time, and if he proved not to exhibit leprosy, the patient was not notified. In the opposite case the patient might have been notified as an ordinary case after a period of observation. Today, prevailing practice with respect to such observation cannot be ascertained. However, if there was a tendency to observe a case for a considerable time before notification, a median of the period longer than 1.4 years would have been expected (Table 5). Accordingly, the high predictive values are considered true.

The relatively lower predictive value of diagnoses made in the district for patients subsequently not admitted to hospital, also indicated a desire to avoid under-registration. During the period in which under-registration might have represented a particular problem, i.e. the first years after the establishment of the registry, efforts in case-finding, expressed by a low predictive value, appeared to have been considerable (Table 6). This finding supported the assumption that under-registration represented no serious problem.

Besides, the relatively higher predictive value of the primary diagnosis in patients later admitted to hospital, should be related to the fact that particularly malignant cases with conspicuous manifestations were hospitalized. The patients not admitted to hospital had a milder clinical course, of ten without characteristic signs and symptoms, implying a lower predictive value of the diagnosis. However, this lower value should also be considered the result of accurate control and a desire to remove all false positive cases from the register. Accordingly, the number of undetected false positive cases among the remaining 3,424 patients in this group is considered low. 


\subsection{Additional sources of data}

\subsubsection{LEPROSY CASES}

The material from the leprosy census of 1836 (Irgens, 1973) is at hand in the National Archives, and the forms were accessible for the compilation of statistics. The results of the leprosy census of 1845 have been published together with the results of the general population census the same year (NOS, 1845).

Apparently, accuracy in case finding varied from census to census, and the results obtained are not directly comparable with statistics based on the registry material. However, assuming approximately the same accuracy in different regions within one census, the results were used for comparisons of time trends in different regions.

\subsubsection{TOTAL POPULATION}

Data on the total population were derived from general population censuses conducted in $1835,1845,1855,1865,1875,1890,1900,1910$ and 1920. The data were published by The Official Statistics of Norway (NOS, 1835; NOS, 1845; NOS, 1855, NOS, 1865; NOS, 1875; NOS, 1890; NOS, 1900; NOS, 1910; NOS, 1920). From 1865 and onwards the censuses were nominative.

Detailed information on emigration from Norway to the USA was obtained from official statistics (NOS, 1921), and was used in an attempt to associate the rapid fall in incidence with a demographic phenomenon particularly found in the high frequency regions.

\subsubsection{ENVIRONMENTAL FACTORS}

In the health district with the highest morbidity rates, Naustdal, data from the census of 1865 , pertaining to the farm section (vide 2.5.2) were processed to obtain detailed information on production and housing (vide 2.5.5). Information on assets was derived from the tax rolls (Matrikkel, 1890). Moreover, ecological data were collected during an excursion to Naustdal, August 1977 (vide 2.5.5). Meteorological observations, organized from 1874, provided climatic data for the entire country (Mohn, 1921).

\subsection{Methods}

\subsubsection{DEFINITION OF OBSERVATION PERIOD}

For 2,289 $(27.8 \%)$ of the total of 8,231 patients, year of onset was reported as before 1856 (Table 12). Accordingly, a considerable amount of the total material could not be used as a basis for calculation of rates. In an attempt to extend the observation period, the case fatality rate of the patients with year of 
onset in the period 1856-60 was studied. Only 5.8\% of these patients were dead by the end of 1860 . For 1,201 patients, year of onset was reported in the period 1851-55. Provided the case fatality rate in this period was the same, only 74 patients $(5 \cdot 8 \%)$ were not registered because they died before 1856 . These patients might represent a biased sample of all patients with year of onset between 1851 and 1855 . However, the small number of patients omitted justified the incorporation of the interval 1851-55 in the observation period.

The 1,088 patients with year of onset before 1851 , obviously constituted a most biased sample of all patients taken ill during the decades prior to the establishment of the registry, representing the patients with the longest survival.

Year of onset between 1921 and 1970 was reported only for 14 patients. Accordingly, an observation period of 70 years from 1851 until 1920 was considered useful for studies of time trends. Information on year of onset was lacking in 477 records. Hence, a total of 6,652 patients were reported as taken ill during the observation period (Table 12).

\subsubsection{DEFINITION OF GEOGRAPHICAL AREAS}

Mean population of the whole country through the observation period was $1,984,791$.

According to the morbidity rates, the country was divided into high and low frequency areas (Fig. 1). The high frequency areas consisted of the counties of West and North Norway, and were divided into the southern region. (Rogaland, Hordaland, Sogn \& Fjordane) with a mean population through the observation period of 380,864 , the middle region (M $\phi \mathrm{re} \&$ Romsdal, S $\phi \mathrm{r}$ Trøndelag, Nord Trøndelag) with a mean population of 328,619 , and the northern region (Nordland, Troms, Finnmark) with a mean population of 212,036 . The low frequency areas consisted of the remaining 10 counties with a mean population of $1,058,175$.

From 1851 to 1920 the proportions of the total population living in the southern region decreased from $20.3 \%$ to $19.0 \%$, in the middle region the proportion decreased from $17.5 \%$ to $15.7 \%$ while in the northern region the proportion increased from $8.9 \%$ to $11.7 \%$. The proportions of the population living in the low frequency areas by 1851 and 1920 were $53.4 \%$ and $53.6 \%$ respectively. Thus, the proportions of the total population living in the different areas were remarkably stable through the observation period.

Sogn \& Fjordane, with a mean population of 87,074 , was the county in which the highest morbidity rates were registered. The health districts of this county were studied in more detail and Naustdal, with a mean population of 2,609, was the health district with the highest rates (Fig. 31).

In a special study of the epidemiological situation in Naustdal, the farm (Norwegian: gaard) was considered the smallest geographical unit for calculation or rates. In some analyses, the farms were divided into the basic units for housing and production, the farm sections (Norwegian: bruk) (vide 2.5.5). 


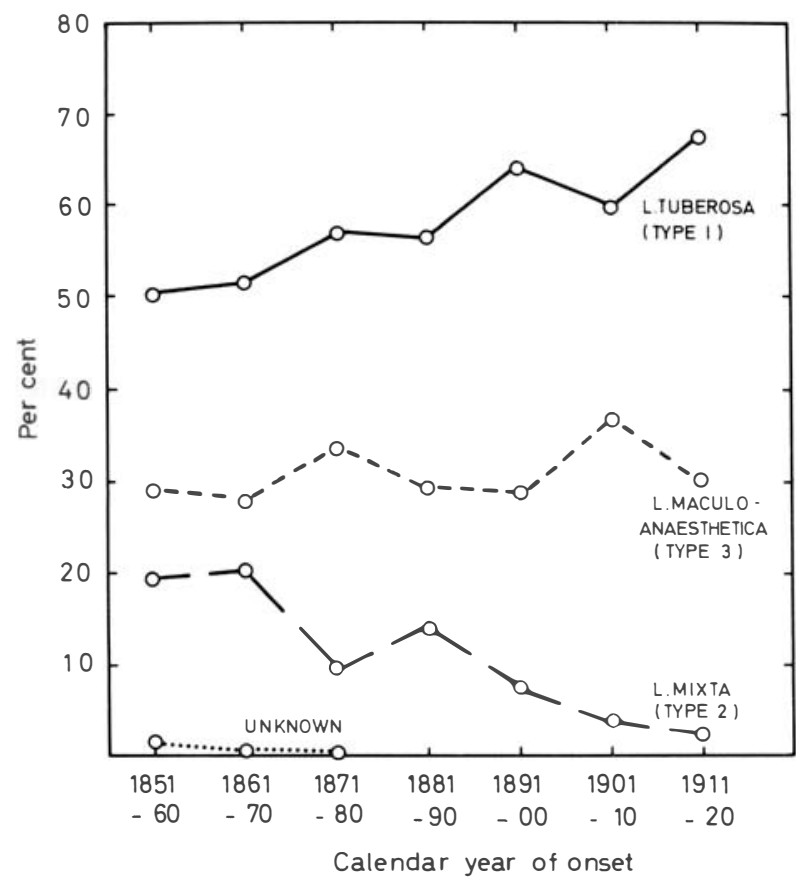

Figure 6. Relative frequencies of types of leprosy in Norway 1851-1920 by year of onset. (The National Leprosy Registry of Norway.)

\subsubsection{EPIDEMIOLOGICAL MEASURES}

In this study, prevalence rate was defined as number of patients at a specified time per 10,000 population. The measure referred to the situation at the end of a year. In some analyses patients in hospital were included in the total number of patients for each district, in others the rate referred only to patients present in the district at the specified time. All patients were included from year of onset, or year of registration, until year of death.

Incidence rate was defined as annual number of new patients, according to year of onset, per 100,000 population and was calculated for intervals of 5 or 10 years. Analyses of time trends in different geographical areas throughout the observation period were based on crude rates. In analyses of time trends in the distribution of cases according to age and sex, age- and sex-adjusted incidence rates were applied.

Average incidence rate was an attack rate referring to the complete observation period. The measure was defined as total number of patients whose year of onset was reported in the observation period, multiplied by 100,000 and divided by the average number of inhabitants in the observation period and by the length of the observation period, i.e. 70 years. Average number of inhabitants was calculated as the sum of the mean number of inhabitants for each of the 7 decades in the observation period, divided by 7 . 
Due to several minor alterations of the borders between the districts, average incidence rates on a district level had to be calculated on the basis of inhabitants present in 1865. At this time approximately one half of the patients had been registered. Since the total number of inhabitants and the composition of the population according to age and sex, varied within narrow limits through the observation period, average incidence rates in these districts were comparable to rates of other areas.

Average incidence rate was used to compare total case load in different geographical areas and to obtain age- and sex-specific incidence rates for the observation period as a total.

In the analysis of the epidemiological situation in the health district of Naustdal, Sogn \& Fjordane, an attack rate called total farm rate was used. The rate was defined as total number of patients registered at a farm divided by number of inhabitants living at the farm in 1865, according to the general population census, and multiplied by 1,000 .

Due to a low number of patients at each farm, it was considered necessary to utilize information on all patients and not only those with year of onset in the observation period, and the measure could not be defined as an annual rate. Accordingly, total farm rates are not comparable to average incidence rates, the latter measure being defined as an annual rate including only patients with year of onset between 1851 and 1920 .

Mortality rate was defined as annual number of deaths among the leprosy patients per 100,000 population, calculated for periods of 5 years. Only crude rates were used.

Sex ratio was calculated as the ratio between male and female age-adjusted incidence rates multiplied by 100 .

Mean age at onset of patients taken ill in a period was calculated on the basis of the number of cases derived by the application of the age- and sexspecific incidence rates of the period on a standard population of 1885. Mean age of the groups $0-14$ years and $50+$ years was calculated as 10.7 years and $60 \cdot 3$ years respectively. The number of cases so derived were also used for the calculation of the proportions of patients in different age groups taken ill in a decade.

At farm level, calculation of sex ratio and mean age at onset could not be based on age- and sex-specific incidence rates, because the numbers of inhabitants in the different age and sex groups present at a farm in 1865 were not considered sufficient as a basis for calculation of age- and sex-specific rates. Accordingly, measures had to be based on crude number of patients.

The most malignant type of leprosy, lepra tuberosa, is called type 1 in the present study; the intermediate type, lepra mixta, is called type 2 ; and the most benign type, lepra maculoanaesthetica, is called type 3. Type of leprosy was registered up to 8 times in a patient record. When nothing else is indicated, type of leprosy in the present study refers to the chronologically last report in which type was stated. 
Type index was calculated as number of type 1 patients divided by the sum of type 1 and type 3 patients multiplied by 100 . Thus the type 2 patients were proportionally distributed into type 1 and 3 . This was necessary to enable comparisons between observations made at different times. Due to instructions from the Chief Medical Officer, classification of a case as type 2 was avoided more and more (Fig. 6) and an index defined as the type-1-proportion of all cases would gradually increase with time, due to a purely administrative decision. Obviously, the type index used in the present study is not suitable as a basis for direct comparisons with a lepromatous index conventionally calculated in other studies, type index tending to be too high. However, in this study, comparisons to other materials of absolute levels on indices rather than trends, were considered precarious and of restricted interest.

\subsubsection{STATISTICAL TESTS}

Statistical tests were based on computer 'packages' (BMDP, 1975, SPSS, 1975).

In general, $\chi^{2}$ tests were used in comparisons of frequencies and $t$-tests in comparisons of arithmetic means. Yate's corrected $\chi^{2}$ was used for fourfold tables (Hamilton, 1979), except for tables in which one or more expected cell values were 20 or smaller. For these tables Fisher's exact test was used.

Simple and multiple regression techniques were used in analyses of possible associations between incidence rates and mean age at onset, sex ratio, and type index, and in analyses of the effects of isolating infectious patients (vide 2.5.5.) In simple and multiple analyses, $p$-values referred to, indicate the probability based on analyses of variance (F-test), that the total variance of the dependent variable is not reduced by the regression function. In simple analyses the p-values may also be interpreted as the probability of non-zero regression coefficients.

Discriminant analysis was used to characterize, by a set of environmental variables, small geographical areas, i.e. farms, respectively with and without leprosy cases.

As a rule, p-values are not given in text or tables; it was considered more important to focus on and discuss trends and gradients in a total view. However, if nothing else is stated, the differences mentioned and discussed are significant, $\mathrm{p}$ being less than $0 \cdot 05$.

\subsubsection{SPECIAL PROCEDURES}

\section{Distribution according to sex, age and type}

A modified Lexis' table (Lexis, 1875) was used as a basis for cohort analyses, describing the occurrence of the disease in consecutive birth cohorts (Fig. 35). Calculation of age- and sex-specific incidence rates in birth cohorts was based on members of each cohort, i.e. all persons born during the period defined by 
the cohort. As numerator, numbers of male and female cohort members for whom onset of leprosy was registered in the specified age group were used. As denominator, estimated numbers of cohort members alive when the cohort reached the specified age groups were used. The rates were calculated per 100,000 population per year. Calculation of mean age at onset in consecutive cohorts was based on age-specific incidence rates and a standard cohort of inhabitants born 1851-60.

\section{Prediction of incidence rates}

Construction of indices, which might be used today as a substitute for incidence rates in areas where such rates are lacking or inaccurate, was based on analyses of associations within an area between characteristics of patients registered in a period and incidence rates in the same period.

The county was chosen as the geographical unit. Material for the analyses was derived from the 7 central counties in the high frequency areas, from Hordaland along the coast to Troms (Fig. 1).

Variables for each county were calculated per decade. The first decade in a county after which a decrease in the incidence rate was observed, and all subsequent decades in the county until 1920, were utilized in the analyses. Decades in which number of patients was less than 4 , were omitted.

The characteristics of patients to be used in the analyses were age at onset, sex and type of leprosy. To avoid errors due to the long observation period, measures based on age and sex-specific incidence rates were preferred to measures based on crude number of patients (vide: 2.5.3). Accordingly, mean age at onset and sex ratio were used, in addition to type index, as independent variables.

Incidence rates, used as dependent variables, were age- and sex-adjusted rates.

The measures, mean age at onset, sex ratio and type index, referring to a specified decade and county, were used as independent variables in simple and stepwise linear regression analyses (BMDP, 1975). The observations were weighted according to number of patients per observation. To predict level of incidence, the logarithm of the observed incidence rate, referring to the same period, was used as the dependent variable. To predict time trend of incidence, the logarithm of the difference between observed incidence rates in the same period and the subsequent period was used as the dependent variable. This difference represents the slope of the straight line drawn through two subsequent observations of incidence rates.

According to the aim of the study, the practical implications of the findings were illustrated by evaluating the validity of the predictions. Thus, the ability of the predictions was assessed to classify correctly the observations to above or below an optimal cut-off point, which referred to level of incidence and time trend of incidence respectively. 


\section{Isolation of patients}

The intentions were to analyse associations, in part between prevalence rates in one period and incidence rates in a subsequent period, in part between isolation in hospitals of infectious patients in one period and relative fall in incidence in a subsequent period.

The county was chosen as the geographical unit, and the material for the analyses was derived from the 7 central counties in the high frequency areas (Fig. 1).

Variables for each county were organized in consecutive double sets of periods from 1856 to 1920 . The quinquenniad 1851-55 had to be excluded because information on isolation in hospital was lacking. In the first period of each set, period 1, the magnitude of the factor whose effect was to be studied, was measured. In the second period, period 2, the presumed effect of the actual factor was quantified. The lengths of these periods had to be chosen so that as much of the effects as possible in period 2 were due only to factors acting in period 1 . In view of the long and varying incubation period of leprosy, this seemed difficult to attain.

However, in the present material the majority of cases were lepromatous, in which mean incubation period appears to cover approximately 10 years (Feldman, 1973). Accordingly, to choose each period to be of 10 years duration, and to let period 2 follow immediately after period 1, involving a mean incubation period of 10 years, seemed justified. Thus 5 double sets for each county were obtained from 1856 to 1915 .

The associations between the variables were assessed by simple linear regression analysis (BMDP, 1975). The p-values indicate the probability that the regression coefficient is equal to zero.

In the first analysis the association between prevalence as a factor in period 1 and incidence as an effect in period 2 was examined. In part, prevalence rates of a county in a period were calculated on the basis of total patient years in the period, of patients registered in the county, spent either in the households or in leprosy hospitals. In part, prevalence rates were calculated on the basis of patient years spent in households only. Mean population of the county in the same period, multiplied by the length of the period in years, was used as the denominator. Age- and sex-adjusted incidence rates were used.

In the next analysis, the association between degree of isolation in period 1 as a factor and relative fall in incidence rates between period 1 and period 2 as an effect was examined. Degree of isolation in a county was expressed by the number of patient years spent in hospital in percent of total number of patient years spent by patients registered in the county. Relative fall in incidence was calculated by incidence rate in period 1 minus incidence rate in period 2 divided by incidence rate in period 1 .

Sets of periods in which prevalence or incidence rates in period 1 were 0 , were omitted in the analyses. 


\section{Leprosy in families}

A family was defined as a group of patients known to be mutually related in some way. Families of different categories were considered: all patients mutually related, siblings, one or two parents with their children and spouses. In the different categories, the families were divided into groups according to number of patients, and each group of families was divided into subgroups according to numbers of patients in the family with the three different types of leprosy.

A special test was performed to study whether the distribution of cases in the families with respect to type was random or whether special subgroups of families were particularly common. Based on observed frequencies in each group of the three different types, and on the assumption of independence with respect to the type of disease between members of any one family, expected frequencies in each group of all possible subgroups were calculated. Expected number of subgroups were compared with observed number by a $\chi^{2}$ statistic, and $\chi^{2}$ values for all groups were added to characterize a category of families.

To study direction of trend in possible differences between observed and expected number of different subgroups, a special measure was constructed: mean distance with respect to type of the disease between patients in a family. Distances within all possible pairs of patients in a family were calculated as the difference between the figures indicating the type of the disease: e.g. the distance between a patient with type 1 and a patient with type 3 was 2 . In a family with $n$ patients, $\frac{1}{2} n(n-1)$ pairs of distances were obtained. Mean distance between patients in a family was calculated as the sum of all distances divided by number of pairs or distances. In a group of families, mean distance between patients was calculated as the sum of mean distances within the families divided by number of families. To calculate mean distance between patients in a category of families, mean distance for each group was weighted according to total number of patients.

This observed distance between patients was compared with an expected mean distance calculated on the basis of expected number of the different subgroups.

A modified procedure was applied when pairs of parents and their children were analysed, calculating a simple mean on the basis of all pairs.

\section{Leprosy in a high frequency district}

This part of the study was based on allocation, within a health district, of all patients registered to their appropriate farms. Registration of the patients' surname, which was the name of the residential farm, made such an allocation possible. The farm was the smallest geographical area for which disease rates could be calculated. However, in Norway the farm, to which the name is attached, is not the basic unit of housing and production. Each farm is divided 
into sections with identical names, owned by one peasant and his family. Theoretically of equal rank, these sections may differ considerably with respect to production, housing and assets.

The leprosy status of the farm, viz. leprosy positive or leprosy negative, was related to whether leprosy cases were registered at the farm or not. Leprosy status of the farm and total farm rate were used as dependent variables in a series of analyses, and were related to independent farm variables on production, housing and assets derived from the general population census of 1865 .

The variables on production were based on amounts of oats and potatoes sown each year, stated in bushels (= toenner, 1 toenne $=139$ litres), and were calculated per person living at the farm in 1865. A production unit was defined as one bushel of oats or potatoes. In addition a relative estimate of production of milk was based on number of cows. In the whole district a total of $6 \cdot 3$ production units of oats and potatoes were produced per cow. Accordingly, to introduce a production unit comparable with the units for production of oats and potatoes, 1 cow was defined as representing $6 \cdot 3$ production units for production of milk.

Housing conditions were quantified by the variable: number of persons per house.

Information on assets was derived from the tax rolls referring to the basis for taxation prepared in the 1870's stating the tax values in oere (taxation of total land properties in Norway was 50 million oere) for each farm (Matrikkel, 1890). The variable: tax value per farm section was used to characterize a farm.

Still, a variable at farm level, e.g. total production of oats per person, might cover a considerable range with some wealthy and some poor farm sections. However, information in the census on production and housing was available at farm section level. Accordingly, to characterize a farm, a farm index was used in addition to the other variables. The farm index was defined as the proportion at each farm of farm sections where the value of the actual variable exceeded a fixed limit. Farm index for production was related to farm sections where production per person was lower than the 25-percentile, while farm index for housing was related to farm sections where number of persons per house was higher than the 75-percentile. The percentiles were based on information on all farm sections in the health district, and were used to obtain a practical relative scale of production and housing.

Tax value for each farm section was not known, and the proportion of farm sections at each farm with a tax value less than the 25 -percentile, could not be calculated.

To test the hypothesis that sphagnum vegetation under special conditions may represent a source of mycobacteria in nature, relevant to the occurrence of leprosy in man (Kazda et al., 1979), leprosy status of the farm and total farm rate were compared with a sphagnum index calculated for each farm. This index was based on information derived from the map and observations made during an excursion to Naustdal, August 1977. The 7 discriminating variables, 
Table 11. Recoded values of the discriminating variables used in the construction of the sphagnum index

\begin{tabular}{|c|c|c|c|}
\hline & Variables & Possible observations & Recoded values \\
\hline Var. 1 & $\begin{array}{l}\text { Sphagnum vegetation } \\
\text { in the neighbourhood }\end{array}$ & $\begin{array}{l}\text { Present } \\
\text { Not present }\end{array}$ & $\begin{array}{l}2 \\
1\end{array}$ \\
\hline Var. 2 & $\begin{array}{l}\text { Height of vegetation } \\
\text { above sea level } \\
\text { (metres) }\end{array}$ & $\begin{array}{l}\text { No vegetation } \\
0-174 \\
175-349 \\
350-524 \\
525+\end{array}$ & $\begin{array}{l}1 \\
5 \\
4 \\
3 \\
2\end{array}$ \\
\hline Var. 3 & $\begin{array}{l}\text { Orientation of } \\
\text { vegetation }\end{array}$ & $\begin{array}{l}\text { No vegetation } \\
\text { North } \\
\text { North East, North West } \\
\text { East, West } \\
\text { South East, South West } \\
\text { South }\end{array}$ & $\begin{array}{l}1 \\
2 \\
3 \\
4 \\
5 \\
6\end{array}$ \\
\hline Var. 4 & $\begin{array}{l}\text { Distance between } \\
\text { vegetation and farm } \\
\text { (metres) }\end{array}$ & $\begin{array}{l}\text { No vegetation } \\
0-499 \\
500-999 \\
1000-1499 \\
1500+\end{array}$ & $\begin{array}{l}1 \\
2 \\
3 \\
4 \\
5\end{array}$ \\
\hline Var. 5 & $\begin{array}{l}\text { Height of farm } \\
\text { above sea level } \\
\text { (metres) }\end{array}$ & $\begin{array}{l}0-124 \\
125-249 \\
250-374 \\
375+\end{array}$ & $\begin{array}{l}4 \\
3 \\
2 \\
1\end{array}$ \\
\hline Var. 6 & Orientation of farm & $\begin{array}{l}\text { North } \\
\text { North East, North West } \\
\text { East, West } \\
\text { South East, South West } \\
\text { South }\end{array}$ & $\begin{array}{l}1 \\
2 \\
3 \\
4 \\
5\end{array}$ \\
\hline Var. 7 & $\begin{array}{l}\text { Water supply of } \\
\text { the farm }\end{array}$ & $\begin{array}{l}\text { Diffusion through sphagnum vegetation } \\
\text { River through sphagnum vegetation } \\
\text { Well without sphagnum vegetation } \\
\text { Others without sphagnum vegetation } \\
\text { Unknown }\end{array}$ & $\begin{array}{l}3 \\
2 \\
1 \\
1 \\
2\end{array}$ \\
\hline
\end{tabular}

the sphagnum variables (Table 11), used in the construction of the index were: (var. 1) whether sphagnum vegetation was present in the surroundings or not (observed in the field), (var. 2) altitude and (var. 3) orientation of possible vegetation (observed in the field and derived from the map), (var. 4) distance from the vegetation to the farm (observed in the field and derived from the map), (var. 5) altitude and (var. 6) orientation of the farm (derived from the map) and (var. 7) water supply of the farm in the last century (observed in the field).

All possible values of each variable were recoded by the use of consecutive whole numbers. High numbers were assigned to values, which, according to the 
hypothesis, were most likely associated with good conditions of mycobacterial growth (Kazda, 1979) (e.g. southern orientation and low altitudes), and with a high risk for the inhabitants of contact with the vegetation (e.g. drinking water supplied to the farm by diffusion through vegetation and short distance to the vegetation).

For each discriminating variable, weighting coefficients were determined by two-group linear discriminant analysis (SPSS, 1975) with all leprosy positive farms in one group, and all leprosy negative farms in the other group.

The discriminant function was defined as the sphagnum index of a farm and was calculated as the sum of the products of the weighting coefficients and the recoded values of the discriminating variables.

The relative importance of the individual farm- and sphagnum-variables was assessed in stepwise two-group linear discriminant analyses with leprosy positive and negative farms in the two groups, selecting the variable which would maximize Rao's V. (SPSS, 1975).

The discriminating power of all sphagnum variables, of all farm variables and of all environmental variables pooled together, was compared by an assessment of to what extent discriminant functions, based on the variables, would give a correct classification of the farms as leprosy positive or negative. As cutoff points for each of the functions, the values which would provide the most correct classification, were chosen.

The risk that a farm was a leprosy farm, when its values of the different functions exceeded the optimal cut-off point, was compared with the risk that a farm below the cut-off point was a leprosy farm by a ratio of risks:

$$
R=\frac{\frac{a}{a+c}}{\frac{b}{b+d}}
$$

Here, $a$ and $c$ denote the frequencies of farms with values above the cut-off point, respectively leprosy positive and negative farms, while $b$ and $d$ denote the frequencies of farms with values below the cut-off point, respectively leprosy positive and negative farms. 



\section{Results}

\subsection{Geographical distribution}

Geographical distribution of the disease is in part described for the observation period as a whole, in part time trends in different regions are related. Furthermore, the geographical distribution of the disease, according to some variables of possible aetiological relevance, is analyzed.

\subsubsection{THE OBSERVATION PERIOD AS A WHOLE}

Average incidence rate for the whole country was $4 \cdot 8$ (Table 12), however, the occurrence of the disease varied considerably from region to region (Fig. 1). Of 6,652 patients with year of onset within the observation period, $143(2 \cdot 2 \%)$ patients were living in the low frequency areas, where the average incidence rate was $0 \cdot 19$. The remaining $6,509(97 \cdot 8 \%)$ patients were living in the high frequency areas, where the average incidence rate was $10 \cdot 0$ (Table 13).

\section{High frequency areas}

Also within the high frequency areas the occurrence of the disease varied considerably. In the southern, middle and northern regions the average incidence rates amounted to $11 \cdot 8,9 \cdot 8$ and $7 \cdot 6$ respectively (Table 12 ).

Sogn \& Fjordane (Fig. 1) with an average incidence rate of $28 \cdot 1$, was the county with the highest rate. Along the coast in both directions, average incidence rates declined, however, with a minor peak of 10.5 in Nordland. At health district level, the highest average incidence rate was found in Naustdal, Sogn \& Fjordane, with a rate of 92·6. (Fig. 31 ).

\section{Low frequency areas}

The cases in the low frequency areas were particularly located in two counties. Of 143 patients registered during the observation period, 55 (38.4\%) lived in the county of Oppland (Fig. 1); the neighbouring county of Sogn \& Fjordane on the other side of the high mountain plateau and to some extent connected by transmountain communications. Another 51 (35.7\%) of the patients lived in the south-eastern parts of the county of Hedmark, a county lacking any 
Table 12. New cases of leprosy in Norway with annual incidence rates per 100,000 by year of onset and residential district. (The National Leprosy Registry of Norway)

\begin{tabular}{|c|c|c|c|c|c|c|c|c|c|c|}
\hline \multirow{3}{*}{$\begin{array}{c}\text { Year of } \\
\text { onset }\end{array}$} & & & \multicolumn{6}{|c|}{ High frequency areas } & \multirow{2}{*}{\multicolumn{2}{|c|}{$\begin{array}{c}\text { Low frequency } \\
\text { areas }\end{array}$}} \\
\hline & \multicolumn{2}{|c|}{ Total } & \multicolumn{2}{|c|}{ Southern region } & \multicolumn{2}{|c|}{ Middle region } & \multicolumn{2}{|c|}{ Northern region } & & \\
\hline & No. & Incidence & No. & Incidence & No. & Incidence & No. & Incidence & No. & Incidence \\
\hline-1850 & 1,088 & & 685 & & 226 & & 153 & & 24 & \\
\hline $1851-1855$ & 1,201 & $16 \cdot 6$ & 697 & $47 \cdot 3$ & 342 & $26 \cdot 9$ & 135 & $21 \cdot 5$ & 27 & $0 \cdot 81$ \\
\hline $1856-1860$ & 1,154 & $14 \cdot 9$ & 604 & $39 \cdot 0$ & 366 & $27 \cdot 2$ & 174 & $25 \cdot 2$ & 10 & $0 \cdot 28$ \\
\hline $1861-1865$ & 1,009 & $12 \cdot 2$ & 490 & $30 \cdot 1$ & 343 & $23 \cdot 9$ & 160 & $21 \cdot 4$ & 16 & $0 \cdot 42$ \\
\hline $1866-1870$ & 996 & $11 \cdot 4$ & 425 & $25 \cdot 2$ & 393 & $26 \cdot 1$ & 162 & $20 \cdot 0$ & 16 & $0 \cdot 40$ \\
\hline $1871-1875$ & 716 & $8 \cdot 0$ & 327 & $18 \cdot 7$ & 248 & $16 \cdot 0$ & 129 & $14 \cdot 7$ & 12 & $0 \cdot 29$ \\
\hline $1876-1880$ & 525 & $5 \cdot 4$ & 209 & $11 \cdot 7$ & 204 & $12 \cdot 9$ & 99 & $10 \cdot 9$ & 13 & $0 \cdot 30$ \\
\hline $1881-1885$ & 340 & $3 \cdot 6$ & 116 & $6 \cdot 2$ & 124 & $7 \cdot 6$ & 90 & $8 \cdot 8$ & 10 & $0 \cdot 22$ \\
\hline $1886-1890$ & 275 & $2 \cdot 6$ & 89 & $4 \cdot 6$ & 104 & $6 \cdot 2$ & 75 & $6 \cdot 6$ & 7 & $0 \cdot 15$ \\
\hline $1891-1895$ & 165 & $1 \cdot 6$ & 70 & $3 \cdot 5$ & 49 & $2 \cdot 9$ & 39 & $3 \cdot 3$ & 7 & $0 \cdot 14$ \\
\hline $1896-1900$ & 111 & $1 \cdot 0$ & 44 & $2 \cdot 1$ & 38 & $2 \cdot 2$ & 23 & $1 \cdot 8$ & 6 & $0 \cdot 12$ \\
\hline 1901-1905 & 87 & 0.6 & 33 & $1 \cdot 5$ & 28 & $1 \cdot 5$ & 17 & $1 \cdot 3$ & 9 & $0 \cdot 16$ \\
\hline 1906-1910 & 30 & $0 \cdot 2$ & 15 & 0.7 & 5 & $0 \cdot 3$ & 6 & $0 \cdot 4$ & 4 & 0.07 \\
\hline $1911-1915$ & 31 & $0 \cdot 2$ & 10 & 0.4 & 8 & 0.4 & 8 & 0.5 & 5 & 0.08 \\
\hline $1916-1920$ & 12 & $0 \cdot 1$ & 3 & $0 \cdot 1$ & 3 & $0 \cdot 2$ & 5 & $0 \cdot 3$ & 1 & $0 \cdot 02$ \\
\hline $1921-1970$ & 14 & & 6 & & 1 & & 3 & & 4 & \\
\hline Unknown & 477 & & 273 & & 140 & & 50 & & 14 & \\
\hline $1851-1920$ & 6,652 & $4 \cdot 8^{\dagger}$ & 3,132 & $11 \cdot 8^{\dagger}$ & 2,255 & $9 \cdot 8^{\dagger}$ & 1,122 & $7 \cdot 6^{\dagger}$ & 143 & $0.19^{\dagger}$ \\
\hline Total & 8,231 & & 4,096 & & 2,622 & & 1,328 & & 185 & \\
\hline
\end{tabular}

† Average incidence rates 
Table 13. New cases of leprosy with annual incidence rates per 100,000 in Norway, high frequency areas, 1851-1920, by year of onset in towns, rural coastal and rural inland health districts. (The National Leprosy Registry of Norway)

\begin{tabular}{|c|c|c|c|c|c|c|c|c|c|c|}
\hline \multirow{4}{*}{$\begin{array}{c}\text { Year of } \\
\text { onset }\end{array}$} & \multicolumn{10}{|c|}{ High frequency areas } \\
\hline & \multirow{2}{*}{\multicolumn{2}{|c|}{ Total }} & \multirow{2}{*}{\multicolumn{2}{|c|}{ Towns }} & \multicolumn{6}{|c|}{ Rural districts } \\
\hline & & & & & \multicolumn{2}{|c|}{ Total } & \multicolumn{2}{|c|}{ Coastal districts } & \multicolumn{2}{|c|}{ Inland districts } \\
\hline & No. & Incidence & No. & Incidence & No. & Incidence & No. & Incidence & No. & Incidence \\
\hline $1851-1860$ & 2,318 & $33 \cdot 4$ & 59 & $9 \cdot 3$ & 2,259 & $35 \cdot 8$ & 1,440 & $46 \cdot 2$ & 819 & $25 \cdot 6$ \\
\hline $1861-1870$ & 1,973 & $25 \cdot 2$ & 70 & $7 \cdot 0$ & 1,903 & $27 \cdot 8$ & 1,309 & $37 \cdot 8$ & 594 & $17 \cdot 6$ \\
\hline $1871-1880$ & 1,216 & $14 \cdot 2$ & 62 & $4 \cdot 9$ & 1,154 & $15 \cdot 8$ & 776 & $20 \cdot 7$ & 378 & $10 \cdot 7$ \\
\hline $1881-1890$ & 598 & $6 \cdot 5$ & 27 & $1 \cdot 8$ & 571 & $7 \cdot 5$ & 418 & $10 \cdot 4$ & 153 & $4 \cdot 2$ \\
\hline 1891-1900 & 263 & $2 \cdot 7$ & 19 & $1 \cdot 1$ & 244 & $3 \cdot 0$ & 183 & $4 \cdot 2$ & 61 & $1 \cdot 6$ \\
\hline 1901-1910 & 104 & $1 \cdot 0$ & 4 & $0 \cdot 18$ & 100 & $1 \cdot 2$ & 74 & $1 \cdot 6$ & 26 & 0.67 \\
\hline 1911-1920 & 37 & $0 \cdot 3$ & 3 & $0 \cdot 11$ & 34 & $0 \cdot 38$ & 31 & 0.62 & 3 & 0.07 \\
\hline Total & 6,509 & $10 \cdot 0^{\dagger}$ & 244 & $2 \cdot 19^{\dagger}$ & 6,265 & $11 \cdot 7^{\dagger}$ & 4,231 & $15 \cdot 0^{\dagger}$ & 2,034 & $7 \cdot 98^{\dagger}$ \\
\hline
\end{tabular}

† Average incidence rates 


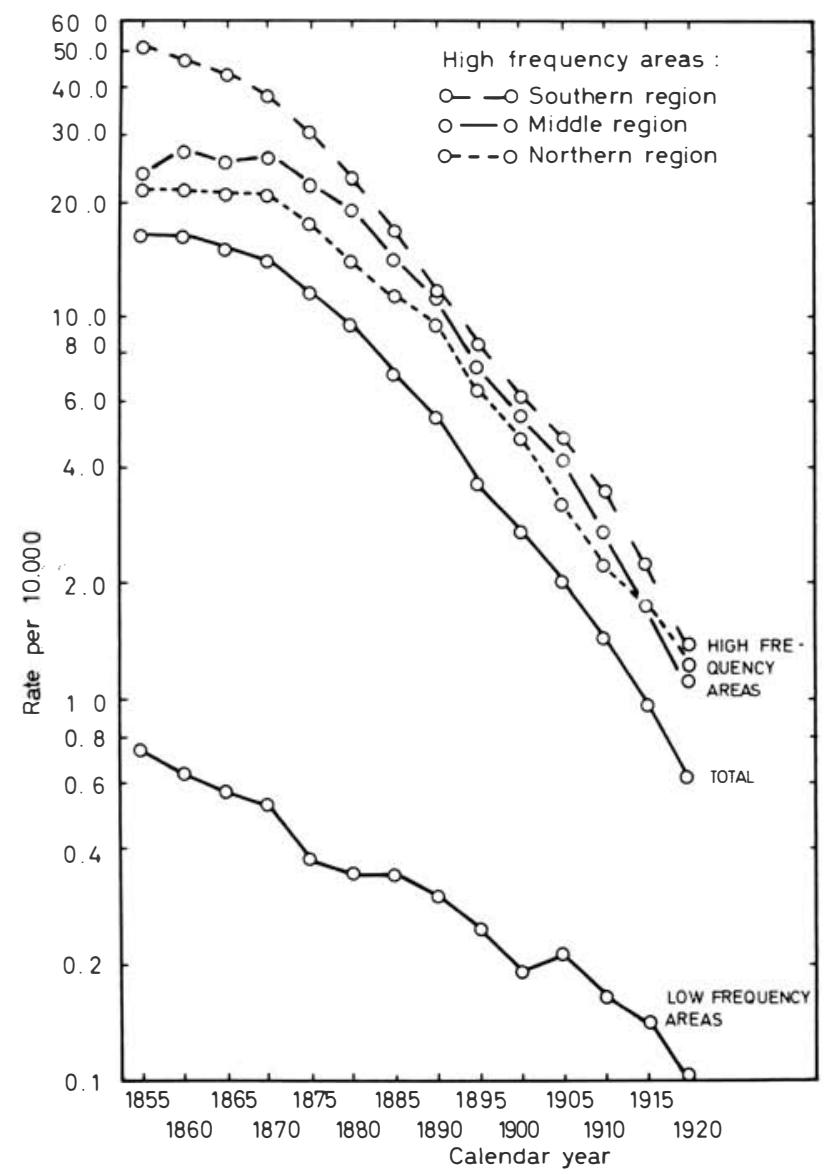

Figure 7. Prevalence rates of leprosy in Norway $1855-1920$ by region. (The National Leprosy Registry of Norway.)

communications with the high frequency areas. The rest, 37 (25.9\%) patients, were scattered, without any concentrations, in the other counties.

\section{Towns and rural districts}

Leprosy was most infrequent in towns. Of the patients taken ill in the high frequency areas during the observation period, 244 (3.7\%) lived in towns and $6,265(96 \cdot 3 \%)$ in rural districts, and the average incidence rates were $2 \cdot 2$ and 11.7 respectively (Table 13 ).

\section{Coast and inland}

Leprosy was also more frequent in districts constituting the coast line than in districts distant from the sea. In the observation period 6,265 patients were taken ill in the rural districts of the high frequency areas; $4,231(67.5 \%)$ patients 
Table 14. Leprosy patients in Norway, 1836-1920, with prevalence rates per 10,000 by residential district when registered. (The National Leprosy Registry of Norway ${ }^{\dagger}$ )

\begin{tabular}{|c|c|c|c|c|c|c|c|c|c|c|}
\hline \multirow[b]{3}{*}{ Year } & & & \multicolumn{6}{|c|}{ High frequency areas } & \multirow{2}{*}{\multicolumn{2}{|c|}{$\begin{array}{c}\text { Low frequency } \\
\text { areas }\end{array}$}} \\
\hline & \multicolumn{2}{|c|}{ Total } & \multicolumn{2}{|c|}{ Southern region } & \multicolumn{2}{|c|}{ Middle region } & \multicolumn{2}{|c|}{ Northern region } & & \\
\hline & No. & Prev. & No. & Prev. & No. & Prev. & No. & Prev. & No. & Prev. \\
\hline 1835 & & & 389 & $14 \cdot 2$ & 121 & $5 \cdot 1$ & 106 & $9 \cdot 6$ & 10 & \\
\hline 1845 & & & 539 & $19 \cdot 7$ & 230 & $9 \cdot 7$ & 141 & $12 \cdot 8$ & 28 & \\
\hline 1855 & 2,492 & $16 \cdot 7$ & 1,531 & $50 \cdot 7$ & 622 & $23 \cdot 9$ & 287 & $21 \cdot 7$ & 52 & 0.75 \\
\hline 1860 & 2,626 & $16 \cdot 5$ & 1,510 & $47 \cdot 5$ & 756 & $27 \cdot 2$ & 312 & $21 \cdot 8$ & 48 & 0.65 \\
\hline 1865 & 2,583 & $15 \cdot 2$ & 1,444 & $43 \cdot 4$ & 763 & $25 \cdot 8$ & 330 & $21 \cdot 2$ & 46 & 0.58 \\
\hline 1870 & 2,489 & $14 \cdot 1$ & 1,292 & $38 \cdot 0$ & 801 & $26 \cdot 3$ & 352 & $21 \cdot 1$ & 44 & 0.54 \\
\hline 1875 & 2,144 & $11 \cdot 8$ & 1,078 & $30 \cdot 3$ & 708 & $22 \cdot 5$ & 326 & $18 \cdot 0$ & 32 & $0 \cdot 38$ \\
\hline 1880 & 1,785 & $9 \cdot 5$ & 854 & $23 \cdot 1$ & 617 & $19 \cdot 1$ & 283 & $14 \cdot 0$ & 31 & 0.36 \\
\hline 1885 & 1,392 & $7 \cdot 2$ & 639 & $17 \cdot 0$ & 469 & $14 \cdot 3$ & 252 & $11 \cdot 8$ & 32 & 0.35 \\
\hline 1890 & 1,091 & $5 \cdot 5$ & 459 & $11 \cdot 9$ & 385 & $11 \cdot 6$ & 218 & $9 \cdot 6$ & 29 & $0 \cdot 31$ \\
\hline 1895 & 781 & $3 \cdot 7$ & 340 & $8 \cdot 6$ & 257 & $7 \cdot 5$ & 159 & $6 \cdot 5$ & 25 & 0.25 \\
\hline 1900 & 614 & $2 \cdot 7$ & 264 & $6 \cdot 2$ & 201 & $5 \cdot 7$ & 128 & $4 \cdot 9$ & 21 & $0 \cdot 20$ \\
\hline 1905 & 479 & $2 \cdot 1$ & 213 & $4 \cdot 9$ & 153 & $4 \cdot 2$ & 89 & $3 \cdot 3$ & 24 & $0 \cdot 22$ \\
\hline 1910 & 347 & $1 \cdot 5$ & 159 & $3 \cdot 5$ & 105 & $2 \cdot 8$ & 64 & $2 \cdot 3$ & 19 & $0 \cdot 17$ \\
\hline 1915 & 245 & $1 \cdot 0$ & 109 & $2 \cdot 3$ & 67 & $1 \cdot 8$ & 52 & $1 \cdot 8$ & 17 & $0 \cdot 14$ \\
\hline 1920 & 167 & 0.6 & 70 & $1 \cdot 4$ & 47 & $1 \cdot 1$ & 38 & $1 \cdot 2$ & 12 & 0.09 \\
\hline
\end{tabular}

†Numbers of cases for 1836 and 1845 are derived from special 'leper censuses'. 


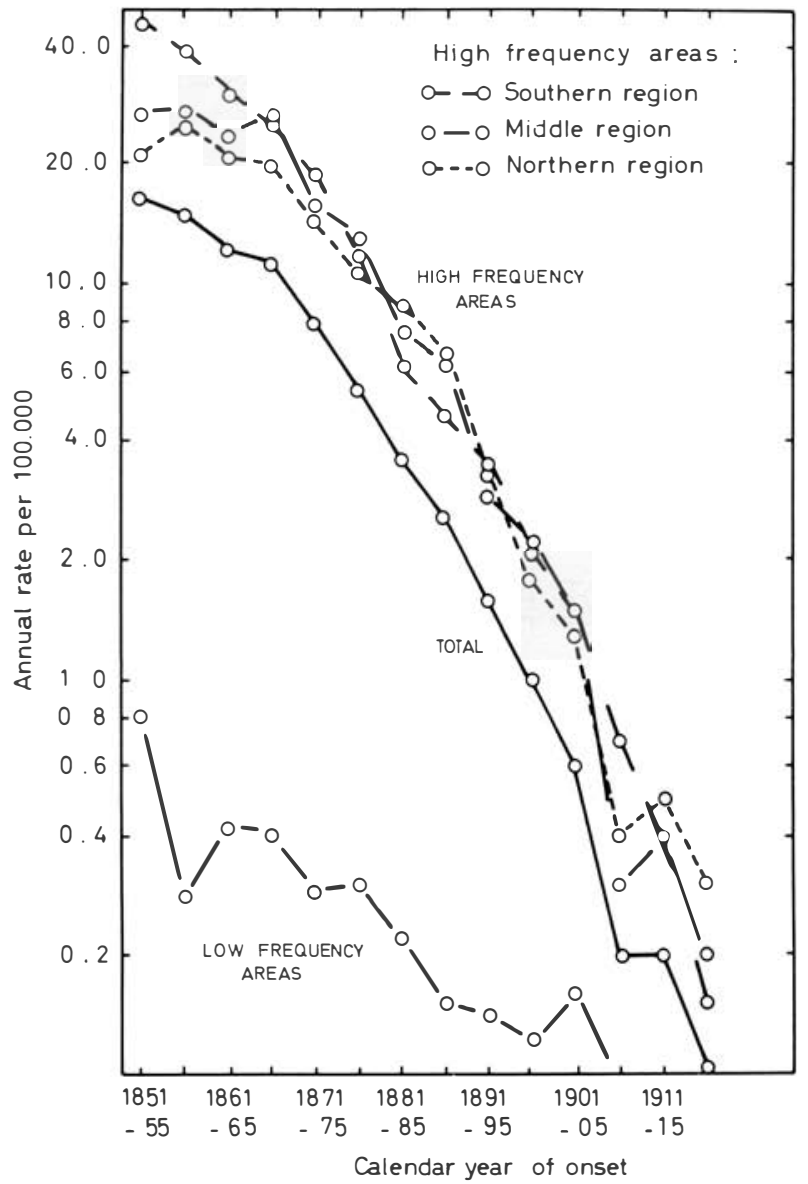

Figure 8. Incidence rates of leprosy in Norway 1851-1920 by region. Crude rates by year of onset. (The National Leprosy Registry of Norway.)

in the coastal districts and 2,034 (32.5\%) in the remaining inland districts. The average incidence rates were $15 \cdot 0$ and $8 \cdot 0$ respectively (Table 13 ).

\subsubsection{TIME TRENDS DURING THE OBSERVATION PERIOD}

For the whole country, the highest morbidity rates were registered in the first part of the observation period with a subsequent rapid fall. The highest prevalence rate, $16 \cdot 7$ per 10,000, was registered in 1855 (Fig. 7, Table 14). In 1860 the rate was almost the same, $16 \cdot 5$. Then the rate declined, with an increasing relative fall throughout the observation period.

The highest incidence rate for the whole country, 16.6 per 100,000 per year, was registered in the period 1851-55 (Fig. 8, Table 12). Also relative fall in incidence rate increased with time. Accordingly, the observation period covered a continuous fall in incidence rates. 


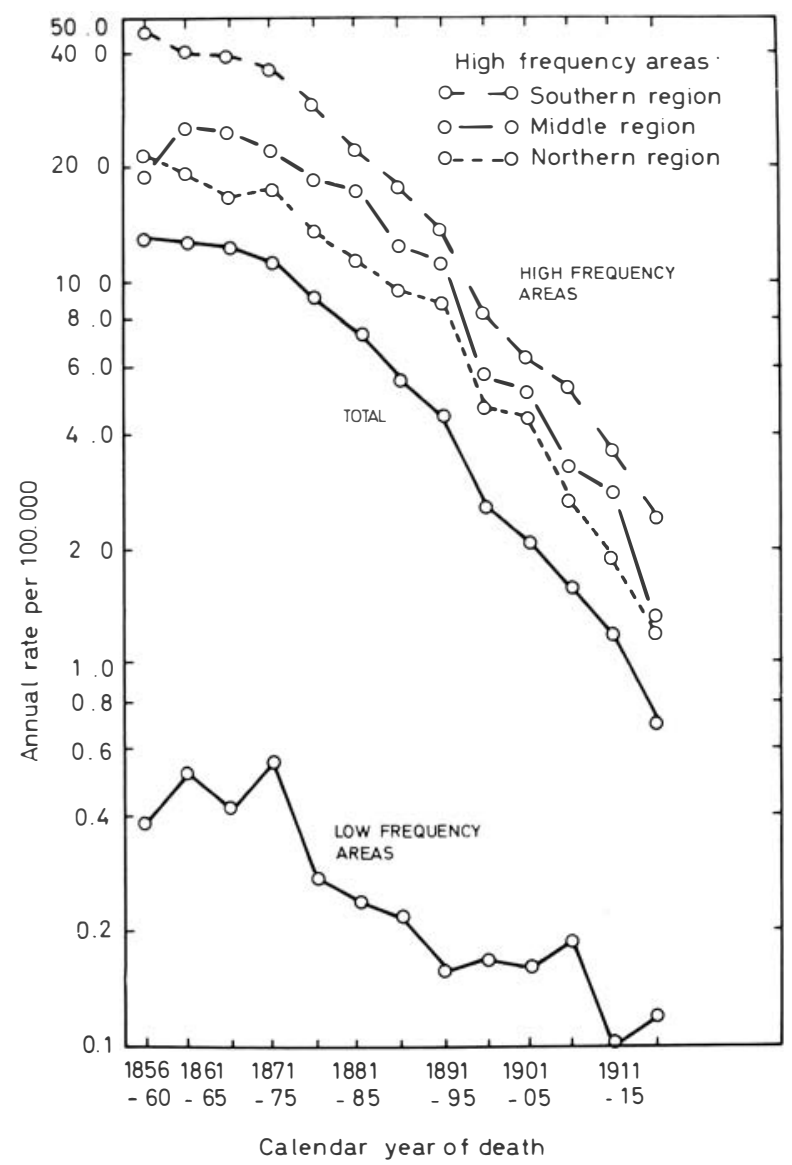

Figure 9. Mortality rates of leprosy in Norway, 1856-1920 by region. Crude rates. (The National Leprosy Registry of Norway)

However, trends in prevalence rates seemed to ascertain that the maximum of the epidemic occurred at the beginning of the period. Prevalence rates, also influenced by the duration of the disease and thus reflecting conditions prior to the time of registration, did not decline until after 1860 .

Trends in mortality rates, still more retrospective than prevalence rates, confirmed the finding; mortality rates did not decline until after 1870 (Fig. 9, Table 15).

For 1,083 patients, taken ill between 1856 and 1860, mean duration of the disease, from year of onset to year of death, was calculated as 12.7 years. Accordingly, fall in incidence appeared to have commenced during the last half of the 1850s.

Although inaccurate and incomplete, the leprosy censuses of 1836 and 1845 also contributed to the documentation that the registry covers a period 
Table 15. Deaths from leprosy in Norway 1856-1920, with annual mortality rates per 100,000, by year of death and residential district. (The National Leprosy Registry of Norway)

\begin{tabular}{|c|c|c|c|c|c|c|c|c|c|c|}
\hline \multirow{3}{*}{$\begin{array}{c}\text { Year of } \\
\text { death }\end{array}$} & & & \multicolumn{6}{|c|}{ High frequency areas } & \multirow{2}{*}{\multicolumn{2}{|c|}{$\begin{array}{c}\text { Low frequency } \\
\text { areas }\end{array}$}} \\
\hline & \multicolumn{2}{|c|}{ Total } & \multicolumn{2}{|c|}{ Southern region } & \multicolumn{2}{|c|}{ Middle region } & \multicolumn{2}{|c|}{ Northern region } & & \\
\hline & No. & Mort. & No. & Mort. & No. & Mort. & No. & Mort. & No. & Mort. \\
\hline $1856-1860$ & 1,005 & $13 \cdot 0$ & 729 & $46 \cdot 7$ & 256 & $19 \cdot 0$ & 147 & $21 \cdot 3$ & 14 & 0.39 \\
\hline $1861-1865$ & 1,046 & $12 \cdot 7$ & 653 & $40 \cdot 2$ & 365 & $25 \cdot 4$ & 144 & $19 \cdot 3$ & 20 & 0.52 \\
\hline $1866-1870$ & 1,056 & $12 \cdot 2$ & 662 & $39 \cdot 3$ & 372 & $24 \cdot 7$ & 135 & $16 \cdot 7$ & 17 & 0.42 \\
\hline $1871-1875$ & 1,005 & $11 \cdot 2$ & 631 & $36 \cdot 1$ & 342 & $22 \cdot 1$ & 153 & $17 \cdot 5$ & 23 & 0.55 \\
\hline $1876-1880$ & 826 & $9 \cdot 0$ & 519 & $28 \cdot 8$ & 291 & $18 \cdot 4$ & 130 & $13 \cdot 7$ & 12 & $0 \cdot 28$ \\
\hline $1881-1885$ & 701 & $7 \cdot 4$ & 408 & $22 \cdot 0$ & 279 & $17 \cdot 2$ & 116 & $11 \cdot 4$ & 11 & $0 \cdot 24$ \\
\hline $1886-1890$ & 551 & $5 \cdot 6$ & 337 & $17 \cdot 6$ & 203 & $12 \cdot 3$ & 104 & $9 \cdot 5$ & 10 & $0 \cdot 22$ \\
\hline $1891-1895$ & 466 & $4 \cdot 5$ & 266 & $13 \cdot 4$ & 187 & $11 \cdot 1$ & 103 & $8 \cdot 8$ & 8 & $0 \cdot 16$ \\
\hline $1896-1900$ & 284 & $2 \cdot 6$ & 171 & $8 \cdot 2$ & 100 & $5 \cdot 7$ & 59 & $4 \cdot 7$ & 9 & $0 \cdot 17$ \\
\hline $1901-1905$ & 240 & $2 \cdot 1$ & 136 & $6 \cdot 3$ & 93 & $5 \cdot 2$ & 58 & $4 \cdot 4$ & 9 & $0 \cdot 16$ \\
\hline $1906-1910$ & 192 & $1 \cdot 6$ & 118 & $5 \cdot 3$ & 61 & $3 \cdot 3$ & 37 & $2 \cdot 7$ & 11 & $0 \cdot 19$ \\
\hline $1911-1915$ & 146 & $1 \cdot 2$ & 85 & $3 \cdot 6$ & 54 & $2 \cdot 8$ & 27 & $1 \cdot 9$ & 6 & $0 \cdot 10$ \\
\hline $1916-1920$ & 95 & $0 \cdot 7$ & 60 & $2 \cdot 4$ & 27 & $1 \cdot 3$ & 18 & $1 \cdot 2$ & 8 & $0 \cdot 12$ \\
\hline
\end{tabular}


from the peak of the epidemic and not only the end of a wave with a far higher maximum at an earlier stage (Table 14).

\section{High frequency areas}

Highest prevalence and incidence rates were registered in the southern region. In 1855 , the prevalence rate was 50.7 per 10,000 , and in the quinquenniad $1851-55$, the incidence rate was $47 \cdot 3$ per 100,000 per year. At the same time prevalence and incidence rates of 101.9 and 97.5 respectively were registered in the county of Sogn \& Fjordance. In the health district of Naustdal, prevalence and incidence rates of 253.0 and 318.3 respectively were registered.

In the southern region a fall in the rates was registered from the beginning of the observation period, with respect to prevalence, incidence and mortality rates (Figs. 7, 8,9). The relative fall in the rates increased with time.

Apparently, the fall in the rates commenced at a later stage in the other high frequency regions. In the middle region a maximum of the prevalence rates was registered between 1860 and 1870. A fall in incidence and mortality rates was registered after 1870 . In the northern region prevalence rates declined from 1870, while incidence and mortality rates declined from 1860 .

Incidence rates declined most rapidly in the southern region, less rapidly in the middle region, and even more slowly in the northern region. Expressed as incidence rate at a specified time in percent of incidence rate 1851-55, this tendency was obvious (Fig. 10).

Further information on time trends in the three regions was at hand in the leprosy censuses of 1836 and 1845 (Table 14). Provided the validity of a census was the same in different districts, the greatest increase in prevalence rates was found in the middle region. Here, prevalence rate increased from $5 \cdot 1$ in 1836 to 23.9 in 1856 ; i.e. by $90.2 \%$ between 1836 and 1845 , and by $146.4 \%$ between 1845 and 1856 . Also in the southern region, a considerable increase was found from 14.2 via 19.7 to 50.7 ; i.e. increases of $38.7 \%$ and $157.4 \%$. In the northern region prevalence rate increased from 9.6 via 12.8 to 21.7 and the relative increases were as low as $33.3 \%$ and $69.5 \%$.

Accordingly, the morbidity rates in the southern region declined rapidly from a high level which may have persisted, more or less, during several decades. The maximum in the middle region was lower, and apparently restricted to a shorter period around the middle of the century. The highest rates registered in the northern region were even lower, and the maximum rates were apparently not restricted to a well-defined, short period. In this region the rates fell relatively slowly.

\section{Low frequency areas}

Prevalence and incidence rates declined from the beginning of the observation period (Figs. 7,8 ) with approximately constant relative fall in rates throughout 


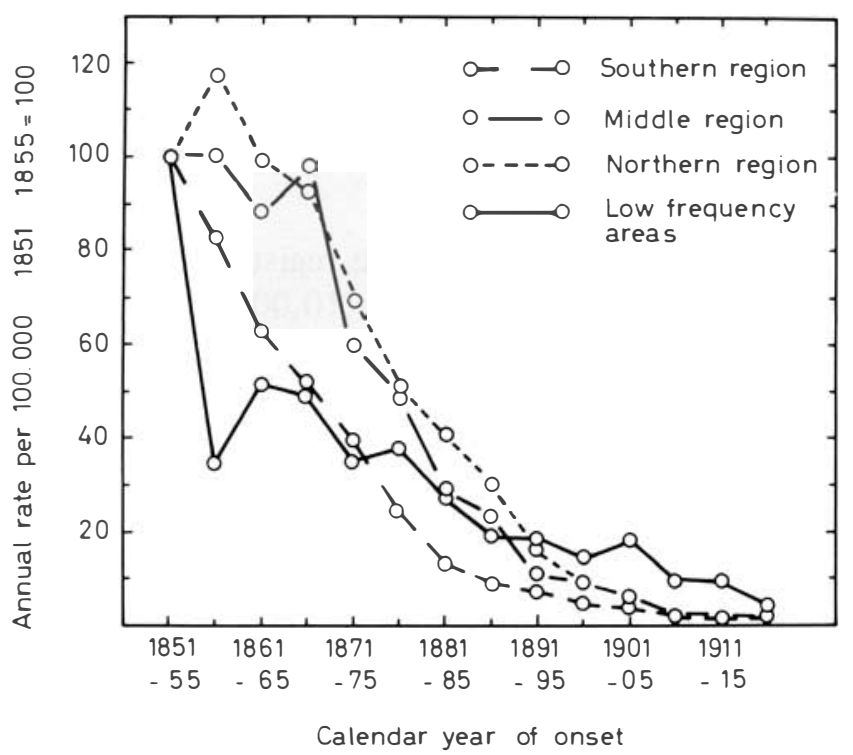

Figure 10. Incidence rates of leprosy in Norway $1851-1920$ by region. Crude rates by year of onset, incidence rate $1851-55=100$. (The National Leprosy Registry of Norway.)

the observation period. For mortality rate, a maximum was registered as late as 1871-75 (Fig. 9). The rates declined more slowly than in the high frequency areas (Fig. 10).

Time trends in mortality rates seemed to ascertain that also in the low frequency areas, the maximum of the epidemic occurred after the beginning of the observation period.

\section{Towns and rural districts}

Time trends in incidence rates for towns and rural districts within the high frequency areas were similar (Fig. 11); incidence rates in towns were approximately one quarter of incidence rates in rural districts throughout the observation period.

\section{Coast and inland}

Also time trends in incidence rates for coastal and inland rural districts were similar (Fig. 11); incidence rates in inland districts were approximately one half of incidence rates in coastal districts throughout the observation period.

\subsubsection{DISTRIBUTION ACCORDING TO SOME CLIMATIC VARIABLES}

Increasing evidence is currently published that a reservoir of mycobacteria, associated with leprosy in man, may be found outside the human body (Shield 


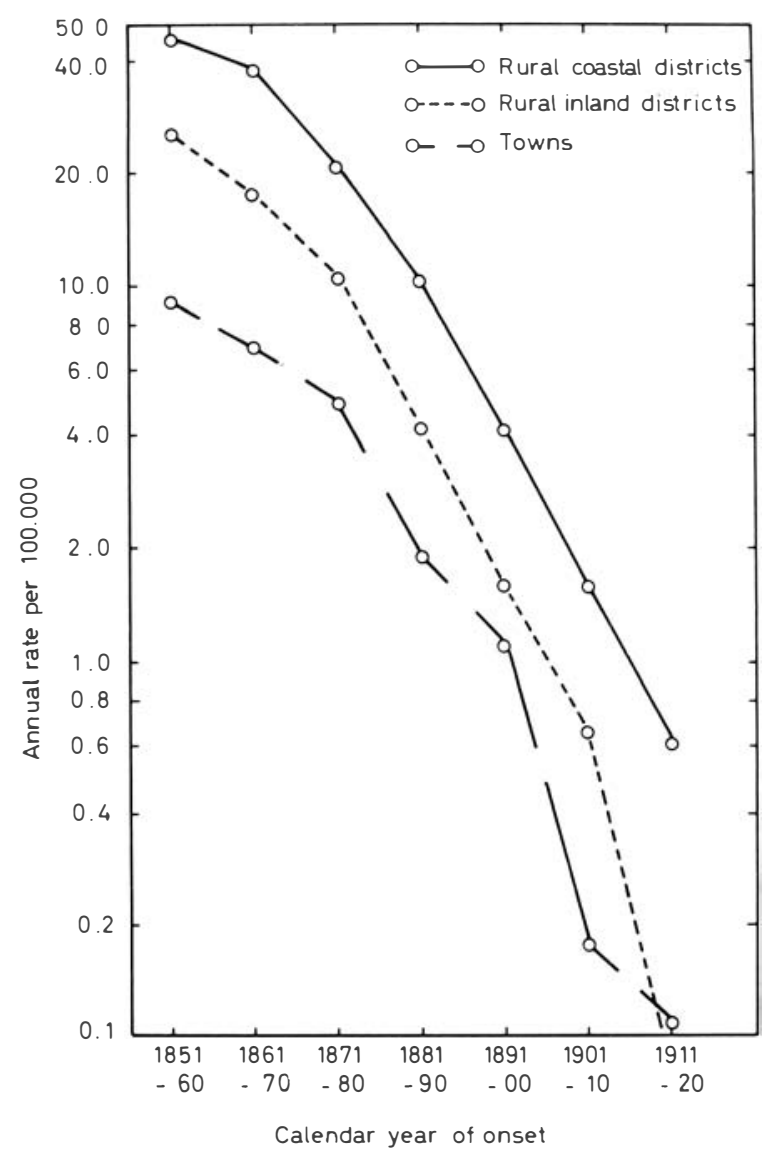

Figure 11. Incidence rates of leprosy in Norway, high frequency areas 1851-1920, in towns, rural coastal and rural inland districts. Crude rates by year of onset. (The National Leprosy Registry of Norway.)

and Stanford, 1977; Walsh et al., 1975; Desikan and Sreevatsa, 1978; Kazda et $a l ., 1979)$. If it is true that $M$. leprae or other mycobacteria which may influence susceptibility of man to leprosy, may survive and multiply outside the human body, the distribution of such mycobacteria may be related to the occurrence of leprosy in man. Apparently, the distribution is dependent on local conditions of multiplication of which humidity and temperature are essential (Kazda, 1979). In an attempt to clarify the question, the occurrence of leprosy was compared with meteorological observations on humidity and temperature in Norway.

\section{Humidity}

Accurate relevant meteorological observations have been made in Norway since 1874 (Mohn, 1921). Mean relative humidity in July from 1874 through 


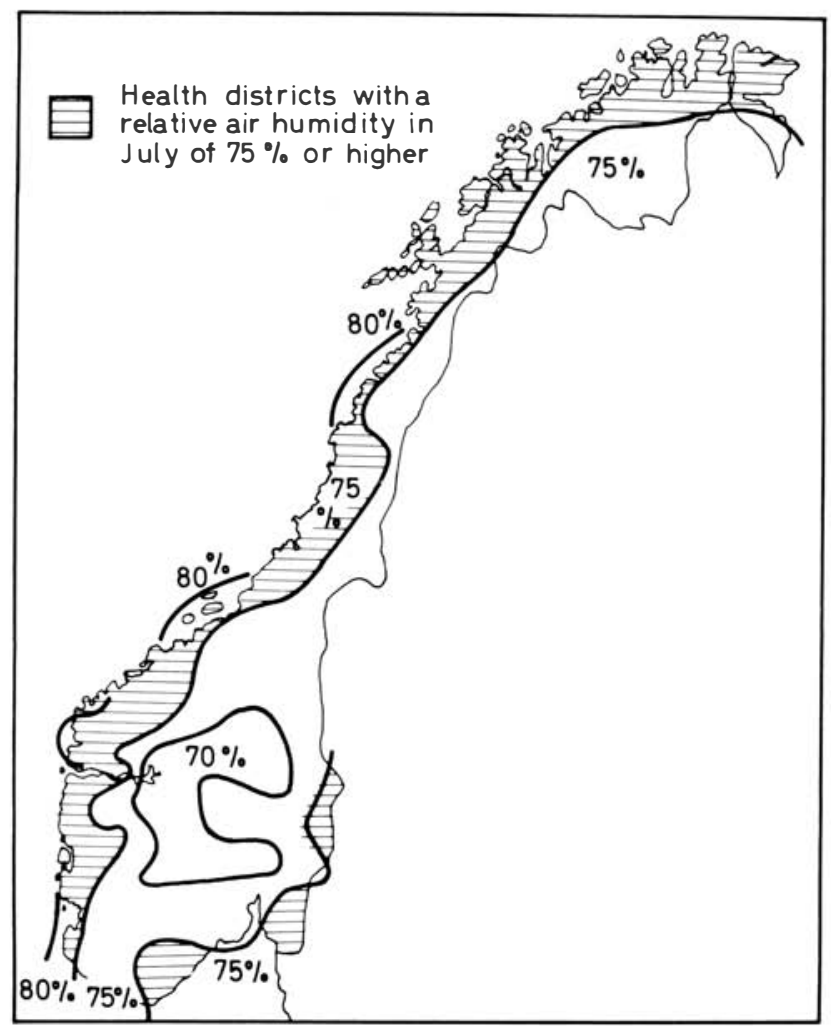

Figure 12. Average relative air humidity in July, 1874-1913, in Norway. (Mohn, 1921.)

1913 at 85 stations ranged from $65 \%$ to $85 \%$ (Fig. 12). In the health districts where relative humidity was $75 \%$ or higher, average incidence rate was 12.4 , while in the other health districts, average incidence rate was 0.7 (Table 16).

\section{Temperature}

Mean air temperature in July ranged from $8.5^{\circ} \mathrm{C}$ to $17^{\circ} \mathrm{C}$ (Fig. 13). In health districts where the temperature was $15^{\circ} \mathrm{C}$ or higher, average incidence rate was $0 \cdot 8$, while in the other districts average incidence rate was $11 \cdot 7$. (Table 17).

\subsubsection{COMMENTS}

A considerable range of morbidity rates was demonstrated in Norway from region to region. This seems also to represent a common pattern of the epidemiology of leprosy in other countries (Hilpert, 1972). Accordingly, WHO has introduced the term 'rate in highest endemic area' (Bechelli and Martinez Dominguez, 1972) as a measure to describe the epidemiological situation in a country.

The highest endemic area in Norway at county level was Sogn \& Fjordane 


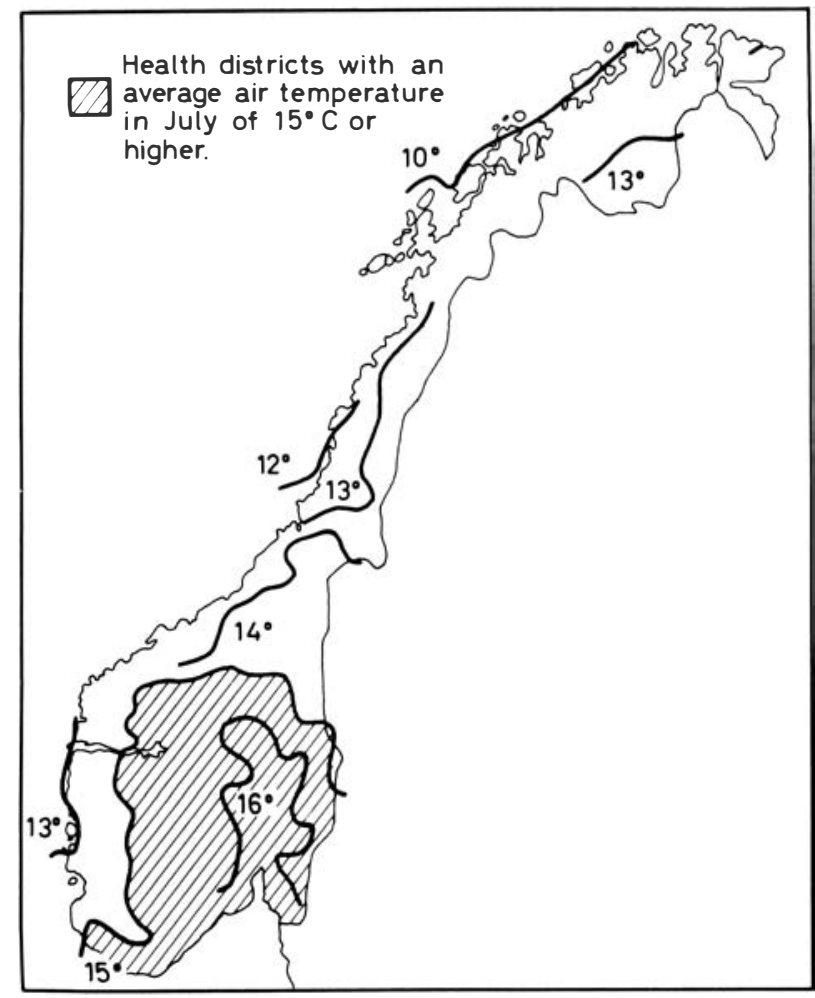

Figure 13. Average air temperature $\left({ }^{\circ} \mathrm{C}\right)$ in July, 1874-1913, in Norway. (Mohn, 1921.)

Table 16. New cases of leprosy 1851-1920 and population in 1865, with average incidence rates, in health districts where relative humidity in July was above or below 75\%. (The National Leprosy Registry of Norway)

\begin{tabular}{cccc}
\hline $\begin{array}{c}\text { Relative } \\
\text { humidity }\end{array}$ & $\begin{array}{c}\text { Patients } \\
1851-1920\end{array}$ & $\begin{array}{c}\text { Population } \\
1865\end{array}$ & $\begin{array}{c}\text { Average } \\
\text { incidence rate }\end{array}$ \\
\hline$\leqslant 74 \%$ & 512 & 993,517 & $12 \cdot 4$ \\
$\geqslant 75 \%$ & 6,140 & 708,239 & $0 \cdot 7$ \\
\hline Total & 6,652 & $1,701,756$ & $5 \cdot 6^{\dagger}$ \\
\hline
\end{tabular}

${ }^{\dagger}$ Based on mean population 1851-1920 instead of population 1865, average incidence rate was $4 \cdot 8$ and not $5 \cdot 6$.

with prevalence and annual incidence rates of 101.9 per 10,000 and 97.5 per 100,000 population respectively. Due to a series of practical problems, comparable statistics from countries where leprosy is prevalent today, are difficult to obtain (Meade, 1971; Lechat, 1973). However, the situation at present may, to some extent, be clarified by WHO-statistics from 1972. Highest prevalence rates were found in Zaire with 1,163 per 10,000. In other African countries, prevalence rates ranged from 20 to 350 . Besides some small areas on islands in the Pacific Ocean, prevalence rates did not exceed 100 in the countries covered by 
Table 17. New cases of leprosy 1851-1920 and population in 1865, with average incidence rates, in health districts where mean temperature in July was above or below $15^{\circ} \mathrm{C}$. (The National Leprosy Registry of Norway)

\begin{tabular}{cccc}
\hline Temperature & Patients & Population & $\begin{array}{c}\text { Average } \\
\text { incidence rate }\end{array}$ \\
\hline$\leqslant 14^{\circ} \mathrm{C}$ & $1851-1920$ & 1865 & $11 \cdot 7$ \\
$\geqslant 15^{\circ} \mathrm{C}$ & 6,128 & 750,554 & $0 \cdot 8$ \\
\hline Total & 524 & 951,202 & $5 \cdot 6^{\dagger}$ \\
\hline
\end{tabular}

† Based on mean population 1851-1920 instead of population 1865, average incidence rate was $4 \cdot 8$ and not $5 \cdot 6$.

this report. Information from India was lacking, however; in areas selected for special surveys, prevalence rates seem to range between 100 and 1,000 per 10,000 (Meade, 1971; Vellut, 1969; Rao et al., 1972a).

Comparable information on incidence rates is even more difficult to obtain. In general, the calculation of reliable incidence rates for a chronic disease, with remissions and relapses like leprosy, has to be based on a patient register. If the exact year of onset is impossible to ascertain, number of new cases in the beginning of an observation period tends to be too high. In special surveys, annual incidence rates range from 1,490 per 100,000 in Zaire (Browne, 1965) to $2 \cdot 6$ in Costa Rica (Monge and Castro, 1968). In New Guinea a level of approximately 600 has been registered (Russell, 1968) and in India the rates have ranged between 86 (Rao et al., 1972b) and 700 (Suresh et al., 1969) per 100,000.

Accordingly, the morbidity rates registered in Norway at the beginning of the observation period, were of the same magnitude as morbidity rates registered in countries where leprosy represents a public health problem today.

\subsection{Distribution according to sex, age and type}

\subsubsection{DISTRIBUTION BY SEX}

\section{According to place}

In the high frequency areas, 3,790 (58.2\%) males and 2,719 (41.8\%) females were taken ill during the observation period, i.e. 139.4 males per 100 females. In the low frequency areas, $83(58.0 \%)$ males and 60 (42.0\%) females were taken ill during the observation period, i.e. $138 \cdot 3$ males per 100 females (Table 18) (vide also Table 38).

\section{According to year of onset}

Of 1,088 patients with year of onset before $1851,546(50 \cdot 2 \%)$ were males and $542(49 \cdot 8 \%)$ were females; i.e. $100 \cdot 7$ males per 100 females (Table 18). Of 
Table 18. Leprosy cases in Norway by sex with mean age at onset according to residential district and year of onset. (The National Leprosy Registry of Norway)

\begin{tabular}{|c|c|c|c|c|c|}
\hline \multirow{3}{*}{$\begin{array}{c}\text { Year of } \\
\text { onset }\end{array}$} & \multirow{3}{*}{$\begin{array}{l}\text { Total } \\
\text { (No.) }\end{array}$} & \multicolumn{2}{|c|}{ Sex } & \multirow{2}{*}{\multicolumn{2}{|c|}{$\begin{array}{l}\text { Of these: Known } \\
\text { age at onset }\end{array}$}} \\
\hline & & \multirow{2}{*}{$\begin{array}{l}\text { Male } \\
\text { (No.) }\end{array}$} & \multirow{2}{*}{$\begin{array}{c}\text { Female } \\
\text { (No.) }\end{array}$} & & \\
\hline & & & & (No.) & $\left(\right.$ mean $\left.^{\dagger}\right)$ \\
\hline \multicolumn{6}{|c|}{ High frequency areas: } \\
\hline-1850 & 1,064 & 534 & 530 & 1,063 & $32 \cdot 9$ \\
\hline $1851-1920$ & 6,509 & 3,790 & 2,719 & 6,471 & $38 \cdot 1$ \\
\hline $1921-1970$ & 10 & 7 & 3 & 10 & - \\
\hline Unknown & 463 & 229 & 234 & 0 & - \\
\hline Total & 8,046 & 4,560 & 3,486 & 7,544 & $37 \cdot 4$ \\
\hline \multicolumn{6}{|c|}{ Low frequency areas: } \\
\hline-1850 & 24 & 12 & 12 & 23 & $38 \cdot 3$ \\
\hline $1851-1920$ & 143 & 83 & 60 & 141 & $44 \cdot 2$ \\
\hline $1921-1970$ & 4 & 4 & 0 & 4 & - \\
\hline Unknown & 14 & 9 & 5 & 0 & - \\
\hline Total & 185 & 108 & 77 & 168 & $43 \cdot 3$ \\
\hline \multicolumn{6}{|l|}{ Total: } \\
\hline-1850 & 1,088 & 546 & 542 & 1,086 & $33 \cdot 0$ \\
\hline $1851-1920$ & 6,652 & 3,873 & 2,779 & 6,612 & $38 \cdot 3$ \\
\hline $1921-1970$ & 14 & 11 & 3 & 14 & - \\
\hline Unknown & 477 & 238 & 239 & 0 & - \\
\hline Total & 8,231 & 4,668 & 3,563 & 7,712 & $37 \cdot 5$ \\
\hline
\end{tabular}

${ }^{\dagger}$ Mean based on crude number of patients.

6,666 patients with year of onset after $1850,3,884(58 \cdot 3 \%)$ were males and $2,782(41 \cdot 7 \%)$ were females; i.e. $139 \cdot 6$ males per 100 females.

In the high frequency areas, average annual age-adjusted incidence rates during the observation period were 13.5 for males and 9.5 for females, with a sex ratio of $142 \cdot 6$. During the observation period age-adjusted sex-specific incidence rates declined continuously; from 37.5 to 0.4 for males, and from 27.5 to $0 \cdot 2$ for females, in the decades $1851-60$ and 1911-20 respectively (Table 19, Fig. 14).

Sex ratio increased during the observation period from 136.4 in the decade 1851-60 to $160 \cdot 3$ in the decade 1911-20. A temporary fall was observed 1891-1900 when sex ratio was as low as $118 \cdot 5$ (Table 19, Fig. 15).

\section{According to age}

Highest average incidence rate for males, 19.9, was observed in the age group 30-49 years and for females, 13.5, in the age group 15-29 years (Table 20, Fig. 16).

Highest sex ratio was observed in the age group 30-40 years with $187 \cdot 2$. In 


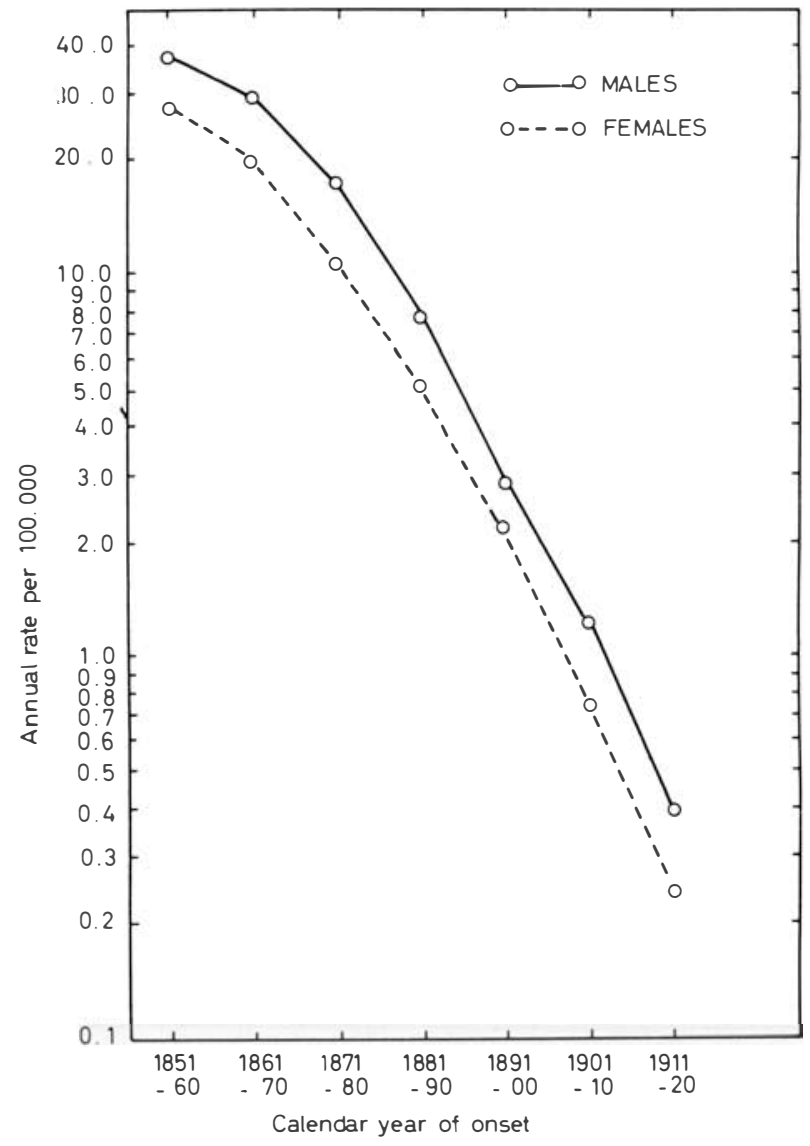

Figure 14. Incidence rates of leprosy in Norway, high frequency areas, 1851-1920. Sexspecific age-adjusted rates by year of onset. (The National Leprosy Registry of Norway.)

the age groups $0-14$ and $15-29$ years, sex ratio was approximately 132 , while in the age group $50+$ sex ratio was $168 \cdot 2$ (Table 20, Fig. 17).

According to age by year of onset

When sex ratio according to age was calculated in subsequent decades, it appeared that the maximum found in the age group 30-49 years, was present only between 1851 and 1880 (Table 20, Fig. 18). After 1880 a maximum in the age group 50+ became more and more evident. Accordingly, the increasing sex ratio towards the end of the observation period, appeared to be due to an increasing sex ratio in elderly patients. 
Table 19. New cases of leprosy in Norway, high frequency areas 18511920 by year of onset, with sex ratio based on incidence rates in consecutive decades, and average incidence rates in the observation period per 100,000. (The National Leprosy Registry of Norway)

\begin{tabular}{cccc}
\hline $\begin{array}{c}\text { Year of } \\
\text { onset }\end{array}$ & $\begin{array}{c}\text { Male } \\
(\text { No. }) \\
\text { (Incidence) }\end{array}$ & $\begin{array}{c}\text { Female } \\
\text { (No.) } \\
\text { (Incidence) }\end{array}$ & Sex ratio \\
\hline $1851-1860$ & 1,323 & 993 & \\
$1861-1870$ & $37 \cdot 5$ & $27 \cdot 5$ & $136 \cdot 4$ \\
$1871-1880$ & 1,150 & 816 & $143 \cdot 4$ \\
$1881-1890$ & $29 \cdot 1$ & $20 \cdot 3$ & $160 \cdot 6$ \\
$1891-1900$ & 727 & 479 & $152 \cdot 3$ \\
$1901-1910$ & 342 & $10 \cdot 8$ & $118 \cdot 5$ \\
$1911-1920$ & $7 \cdot 8$ & 242 & $160 \cdot 2$ \\
& 135 & 124 & \\
& $2 \cdot 9$ & $2 \cdot 4$ & 42 \\
\hline Total & 61 & $0 \cdot 8$ & $160 \cdot 3$ \\
\hline
\end{tabular}

† Average incidence rates.

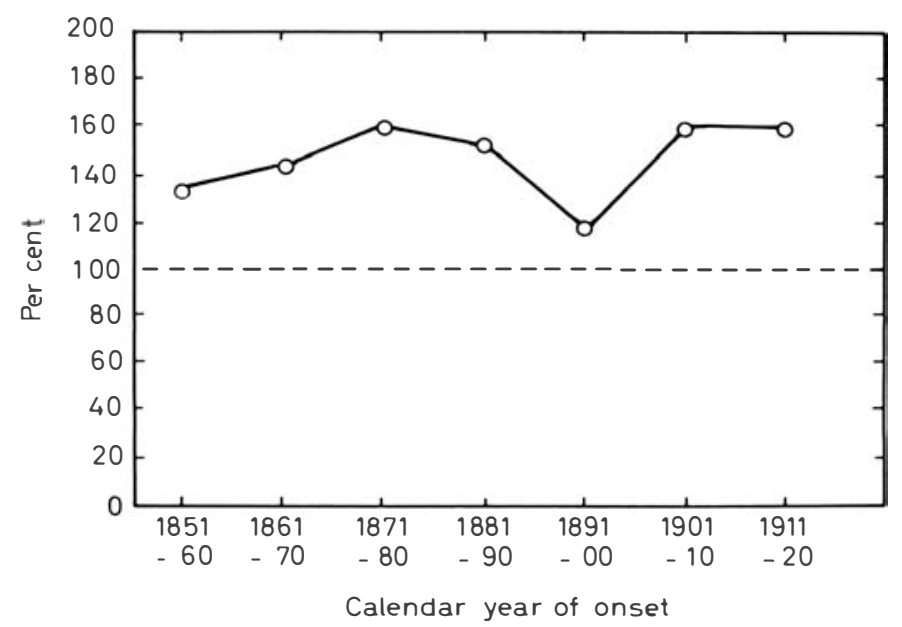

Figure 15. Sex ratio of leprosy in Norway, high frequency areas; 1851-1920 by year of onset. Ratio based on sex-specific age-adjusted incidence rates. (The National Leprosy Registry of Norway.) 
Table 20. New cases of leprosy in Norway, high frequency areas, 1851-1920 by year of onset, with sex ratio based on annual incidence rates in consecutive decades and average incidence rates in the observation period, per 100,000 according to age and sex. (The National Leprosy Registry of Norway)

\begin{tabular}{|c|c|c|c|c|c|c|c|c|}
\hline \multirow[b]{2}{*}{$\begin{array}{l}\text { Year of } \\
\text { onset }\end{array}$} & \multicolumn{2}{|c|}{$0-14$ years } & \multicolumn{2}{|c|}{$15-29$ years } & \multicolumn{2}{|c|}{$30-49$ years } & \multicolumn{2}{|c|}{$50+$ years } \\
\hline & $\begin{array}{c}\text { (No.) } \\
\text { (Incidence) }\end{array}$ & Ratio & $\begin{array}{c}\text { (No.) } \\
\text { (Incidence) }\end{array}$ & Ratio & $\begin{array}{c}\text { (No.) } \\
\text { (Incidence) }\end{array}$ & Ratio & $\begin{array}{c}\text { (No.) } \\
\text { (Incidence) }\end{array}$ & Ratio \\
\hline \multicolumn{9}{|l|}{ Male } \\
\hline $1851-1860$ & $\begin{array}{l}175 \\
14 \cdot 4\end{array}$ & $126 \cdot 3$ & $\begin{array}{l}512 \\
58 \cdot 6\end{array}$ & $132 \cdot 6$ & $\begin{array}{l}447 \\
58 \cdot 0\end{array}$ & $165 \cdot 2$ & $\begin{array}{l}189 \\
35 \cdot 1\end{array}$ & $137 \cdot 1$ \\
\hline $1861-1880$ & $\begin{array}{l}222 \\
7 \cdot 7\end{array}$ & $142 \cdot 6$ & $\begin{array}{l}644 \\
33 \cdot 1\end{array}$ & $121 \cdot 7$ & $\begin{array}{l}682 \\
37 \cdot 8\end{array}$ & $200 \cdot 0$ & $\begin{array}{l}329 \\
25 \cdot 1\end{array}$ & $185 \cdot 9$ \\
\hline $1881-1900$ & $\begin{array}{l}58 \\
1 \cdot 7\end{array}$ & $120 \cdot 7$ & $\begin{array}{r}162 \\
7 \cdot 9\end{array}$ & $147 \cdot 4$ & $\begin{array}{l}144 \\
8 \cdot 0\end{array}$ & $142 \cdot 1$ & $\begin{array}{c}113 \\
6 \cdot 5\end{array}$ & $174 \cdot 1$ \\
\hline $1901-1920$ & $\begin{array}{l}5 \\
0 \cdot 1 \\
\end{array}$ & $95 \cdot 3$ & $\begin{array}{c}17 \\
0 \cdot 7 \\
\end{array}$ & $143 \cdot 0$ & $\begin{array}{c}24 \\
1 \cdot 2 \\
\end{array}$ & $133 \cdot 8$ & $\begin{array}{c}37 \\
1.9 \\
\end{array}$ & $274 \cdot 4$ \\
\hline Total & $\begin{array}{l}460 \\
4 \cdot 0\end{array}$ & $132 \cdot 3$ & $\begin{array}{r}1,335 \\
17 \cdot 8 \\
\end{array}$ & $131 \cdot 7$ & $\begin{array}{r}1,297 \\
19 \cdot 9 \\
\end{array}$ & $187 \cdot 1$ & $\begin{array}{c}668 \\
11.9\end{array}$ & $168 \cdot 2$ \\
\hline \multicolumn{9}{|l|}{ Female } \\
\hline $1851-1860$ & $\begin{array}{l}133 \\
11 \cdot 4\end{array}$ & & $\begin{array}{l}411 \\
44 \cdot 2\end{array}$ & & $\begin{array}{l}280 \\
35 \cdot 1\end{array}$ & & $\begin{array}{l}169 \\
25 \cdot 6\end{array}$ & \\
\hline $1861-1880$ & $\begin{array}{l}150 \\
5 \cdot 4\end{array}$ & & $\begin{array}{l}569 \\
27 \cdot 2\end{array}$ & & $\begin{array}{l}367 \\
18 \cdot 9\end{array}$ & & $\begin{array}{l}209 \\
13 \cdot 5\end{array}$ & \\
\hline $1880-1900$ & $\begin{array}{l}46 \\
1 \cdot 4\end{array}$ & & $\begin{array}{r}127 \\
5 \cdot 4\end{array}$ & & $\begin{array}{r}118 \\
5 \cdot 6\end{array}$ & & $\begin{array}{l}75 \\
3 \cdot 7\end{array}$ & \\
\hline $1901-1920$ & $\begin{array}{l}5 \\
0 \cdot 1 \\
\end{array}$ & & $\begin{array}{c}14 \\
0 \cdot 5 \\
\end{array}$ & & $\begin{array}{c}22 \\
0.9 \\
\end{array}$ & & $\begin{array}{c}16 \\
0 \cdot 7 \\
\end{array}$ & \\
\hline Total & $\begin{array}{r}334 \\
3 \cdot 0\end{array}$ & & $\begin{array}{r}1,121 \\
13 \cdot 5\end{array}$ & & $\begin{array}{l}787 \\
10 \cdot 6\end{array}$ & & $\begin{array}{l}469 \\
7 \cdot 1\end{array}$ & \\
\hline
\end{tabular}




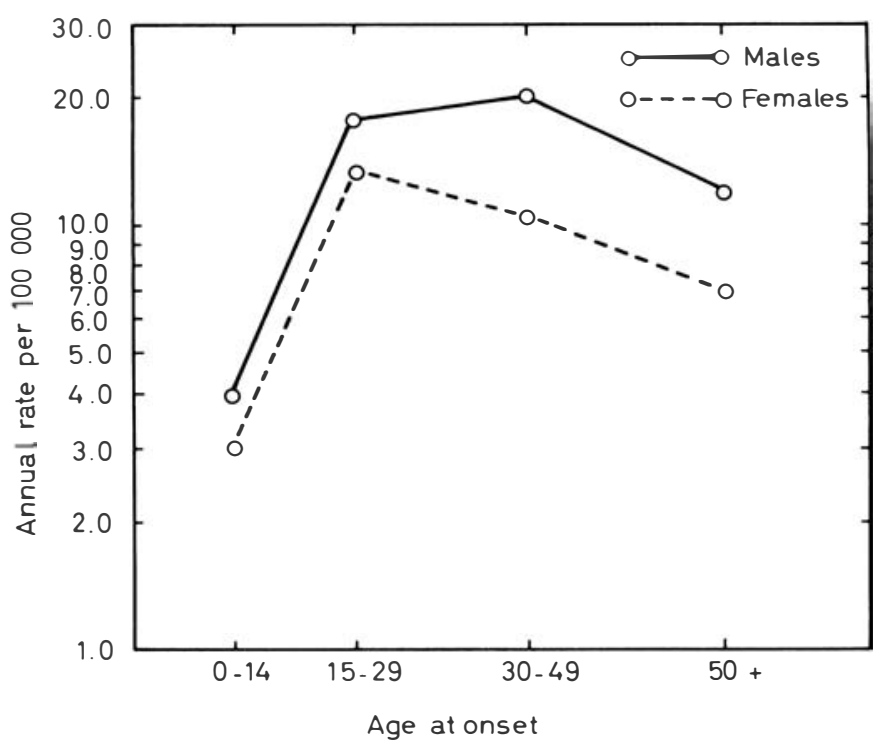

Figure 16. Incidence rates of leprosy in Norway, high frequency areas, 1851-1920. Average age- and sex-specific rates. (The National Leprosy Registry of Norway.)

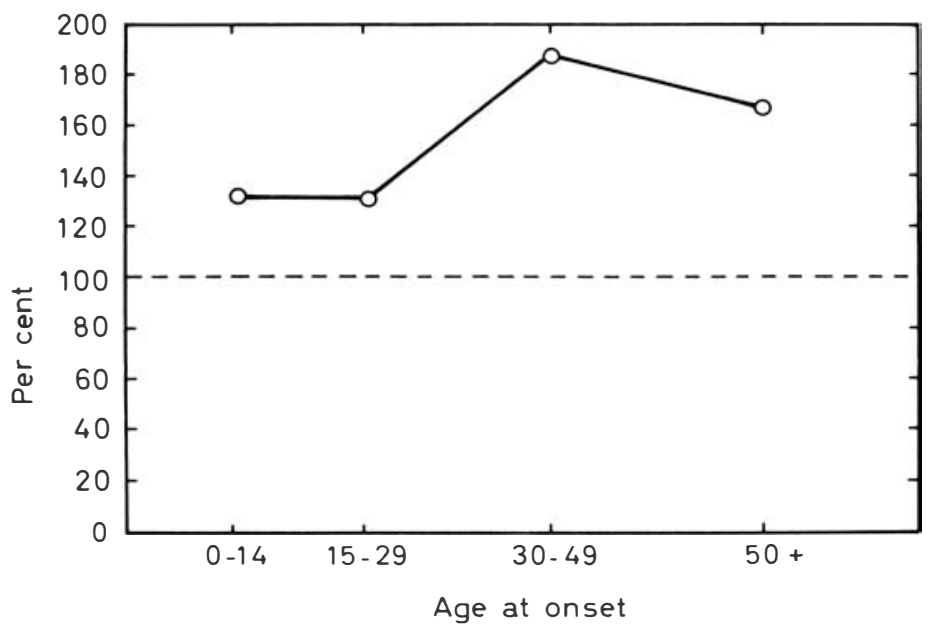

Figure 17. Sex ratio of leprosy in Norway, high frequency areas, 1851-1920, by age. Ratio based on average age- and sex-specific incidence rates. (The National Leprosy Registry of Norway.)

\subsubsection{DISTRIBUTION BY AGE}

\section{According to place}

In the high frequency areas mean age at onset of 6,471 patients taken ill during the observation period was $38 \cdot 1$ years. In the low frequency areas during the 


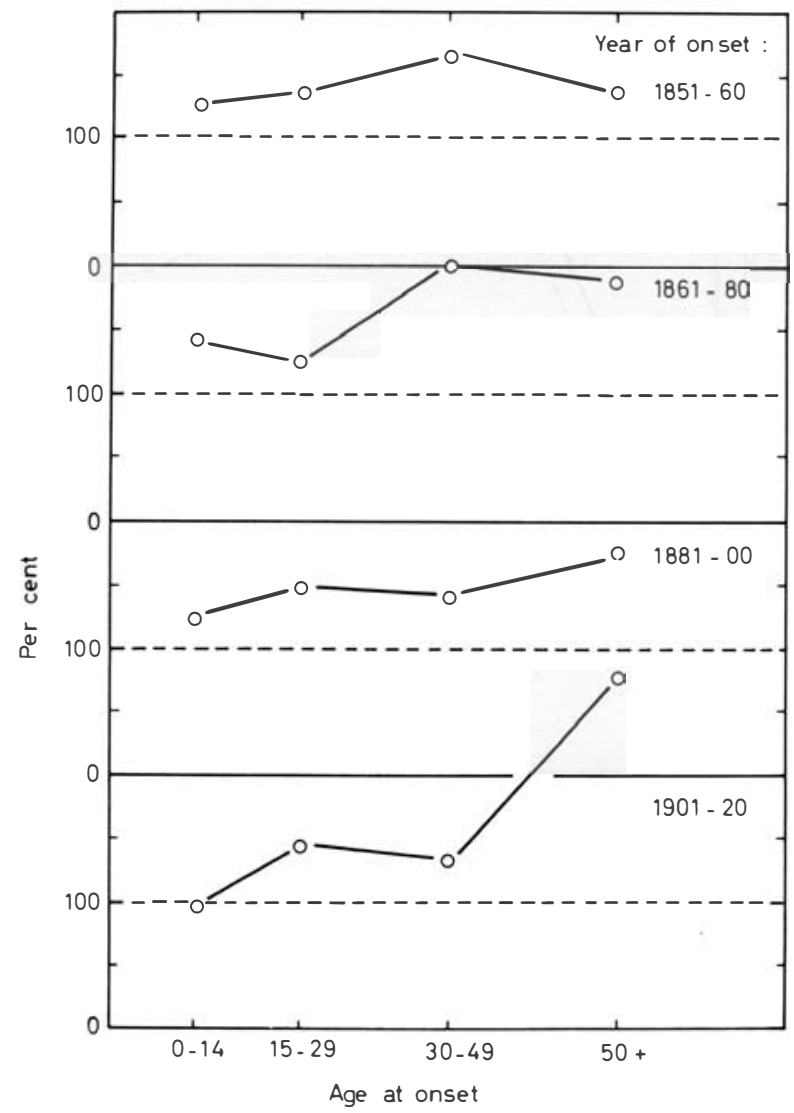

Figure 18. Sex ratio of leprosy in Norway, high frequency areas, 1851-1920, by age and year of onset. Ratio based on age- and sex-specific incidence rates. (The National Leprosy Registry of Norway.)

same period, mean age at onset of 141 patients was $44 \cdot 2$ (Table 18) (vide also Table 38).

\section{According to year of onset}

Mean age at onset of 1,086 patients with known age at onset and with year of onset before 1851 was 33.0 years (Table 18). Mean age at onset of 6,626 patients with known age at onset and with year of onset after 1850 was $38 \cdot 3$.

During the observation period mean age at onset by year of onset, based on age- and sex-specific incidence rates and the standard population of 1885 (vide 2.5.3.), increased almost continuously; for males from 33.0 to 45.9 years, and for females from 32.9 to 43.9 years in the periods $1851-60$ and 1911-20 respectively (Table 21, Fig. 19). In all decades, mean age at onset of males was higher than mean age at onset of females. 


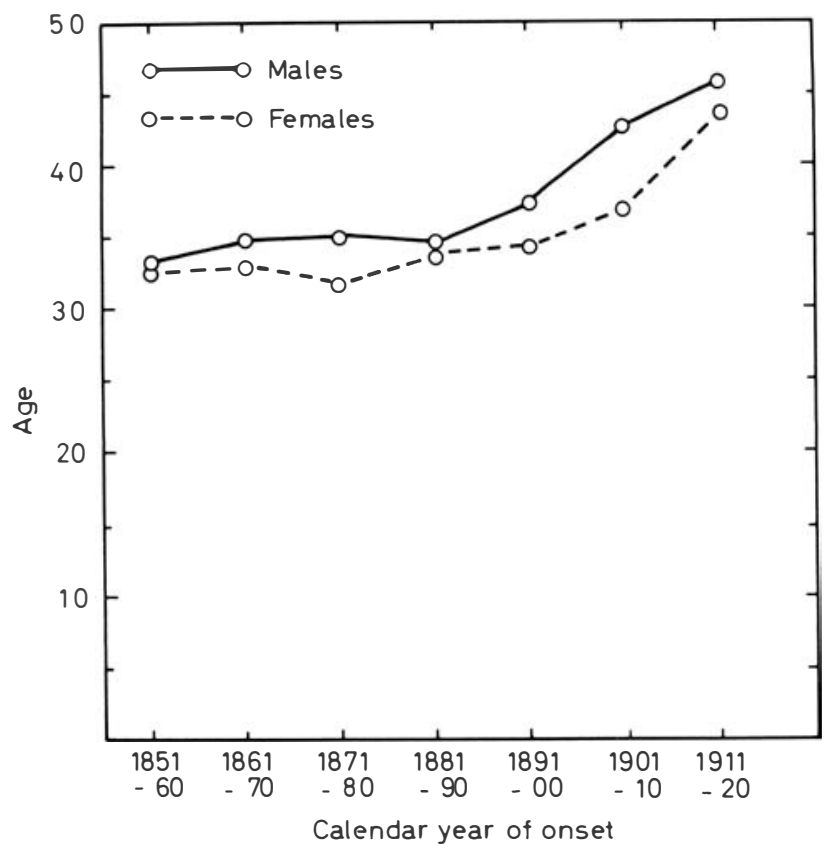

Figure 19. Mean age at onset of leprosy in Norway, high frequency areas, 1851-1920, by sex and year of onset. (The National Leprosy Register of Norway.)

Also age- and sex-specific incidence rates, calculated in consecutive decades, demonstrated that the disease, to an ever increasing extent, attacked older individuals (Table 20, Fig. 20). Thus, in the decade 1851-60, number of patients in the age group $50+$ years, calculated as age- and sex-adjusted patient number (vide 2.5.3.), amounted to $18.2 \%$ of all patients taken ill during the decade (Table 21, Fig. 21). This percentage increased to 46.5 in the decade 1911-20.

\section{According to year of birth}

When age at onset was studied in consecutive birth cohorts, an inverse trend appeared. Mean age at onset, based on age- and sex-specific incidence rates and the standard cohort born 1851-60 (vide 2.5.3.), decreased almost continuously during the observation period; for males from $23 \cdot 1$ to $15 \cdot 1$ years and for females from 22.9 to 10.7 years, for patients born in the decades $1841-50$ and 1891-1900 respectively (Table 23, Fig. 22). In most cohorts mean age at onset of males was higher than mean age at onset of females.

Also age- and sex-specific incidence rates demonstrated that when studied in consecutive cohorts, the disease gradually attacked younger individuals (Table 22, Fig. 23). In the cohort of patients born 1841-50, patients with age at onset between 0 and 14 years, calculated as age- and sex-adjusted patient number (vide 2.5.3.), amounted to $26.4 \%$ of the total cohort, while in the 
Table 21. New cases of leprosy in Norway high frequency areas 1851-1920, by year of onset; actual registered number $\left(n_{1}\right)$ and number calculated on the basis of a standard population and age- and sex-specific incidence rates $\left(n_{2}\right)$, with mean age at onset. (The National Leprosy Registry of Norway)

\begin{tabular}{|c|c|c|c|c|c|c|c|}
\hline \multirow[b]{2}{*}{$\begin{array}{c}\text { Year of } \\
\text { onset }\end{array}$} & \multicolumn{5}{|c|}{ Total } & \multirow[b]{2}{*}{$\begin{array}{l}\text { Male } \\
\text { (mean } \\
\text { age at } \\
\text { onset) }\end{array}$} & \multirow[b]{2}{*}{$\begin{array}{c}\text { Female } \\
\text { (mean } \\
\text { age at } \\
\text { onset) }\end{array}$} \\
\hline & $\begin{array}{l}\text { Total } \\
\left(n_{1}\right) \\
\left(n_{2}\right) \\
(\%)\end{array}$ & $\begin{array}{c}0-14 \text { yrs } \\
\left(n_{1}\right) \\
\left(n_{2}\right) \\
(\%)\end{array}$ & $\begin{array}{c}15-29 \text { yrs } \\
\left(n_{1}\right) \\
\left(n_{2}\right) \\
(\%)\end{array}$ & $\begin{array}{c}30-49 \text { yrs } \\
\left(n_{1}\right) \\
\left(n_{2}\right) \\
(\%)\end{array}$ & $\begin{array}{c}50+y r s \\
\left(n_{1}\right) \\
\left(n_{2}\right) \\
(\%)\end{array}$ & & \\
\hline \multirow[t]{3}{*}{$1851-1860$} & 2,316 & 308 & 923 & 727 & 358 & & \\
\hline & $2,942 \cdot 4$ & $416 \cdot 8$ & $1,108 \cdot 2$ & $882 \cdot 1$ & $535 \cdot 3$ & $33 \cdot 0$ & $32 \cdot 9$ \\
\hline & $100 \cdot 0$ & $14 \cdot 2$ & $37 \cdot 6$ & $30 \cdot 0$ & $18 \cdot 2$ & & \\
\hline \multirow[t]{3}{*}{$1861-1870$} & 1,966 & 234 & 742 & 669 & 321 & & \\
\hline & $2,229 \cdot 5$ & $274 \cdot 7$ & $830 \cdot 1$ & $675 \cdot 8$ & $448 \cdot 9$ & $34 \cdot 6$ & $33 \cdot 1$ \\
\hline & $100 \cdot 0$ & $12 \cdot 3$ & $37 \cdot 2$ & $30 \cdot 3$ & $20 \cdot 2$ & & \\
\hline \multirow{3}{*}{$1871-1880$} & 1,206 & 138 & 471 & 380 & 217 & & \\
\hline & $1,273 \cdot 4$ & $115 \cdot 5$ & $486 \cdot 0$ & $390 \cdot 2$ & $245 \cdot 7$ & $35 \cdot 0$ & $32 \cdot 0$ \\
\hline & $100 \cdot 0$ & $11 \cdot 9$ & $38 \cdot 2$ & $30 \cdot 6$ & $19 \cdot 3$ & & \\
\hline \multirow[t]{3}{*}{$1881-1890$} & 584 & 72 & 205 & 183 & 124 & & \\
\hline & $584 \cdot 0$ & $72 \cdot 0$ & $205 \cdot 0$ & $183 \cdot 0$ & $124 \cdot 0$ & $34 \cdot 7$ & $34 \cdot 3$ \\
\hline & $100 \cdot 0$ & $12 \cdot 3$ & $35 \cdot 1$ & $31 \cdot 3$ & $21 \cdot 3$ & & \\
\hline \multirow[t]{3}{*}{$1891-1900$} & 259 & 32 & 84 & 79 & 64 & & \\
\hline & $240 \cdot 3$ & $29 \cdot 3$ & $77 \cdot 9$ & $75 \cdot 4$ & $57 \cdot 7$ & $36 \cdot 6$ & $34 \cdot 6$ \\
\hline & $100 \cdot 0$ & $12 \cdot 2$ & $32 \cdot 4$ & $31 \cdot 4$ & $24 \cdot 0$ & & \\
\hline \multirow[t]{3}{*}{$1901-1910$} & 103 & 8 & 25 & 34 & 36 & & \\
\hline & $88 \cdot 8$ & $6 \cdot 8$ & $21 \cdot 5$ & $30 \cdot 1$ & $30 \cdot 5$ & $42 \cdot 9$ & $37 \cdot 0$ \\
\hline & $100 \cdot 0$ & $7 \cdot 6$ & $24 \cdot 1$ & $33 \cdot 9$ & $34 \cdot 4$ & & \\
\hline \multirow[t]{3}{*}{$1911-1920$} & 37 & 2 & 6 & 12 & 17 & & \\
\hline & $29 \cdot 1$ & $1 \cdot 7$ & $4 \cdot 5$ & $9 \cdot 4$ & $13 \cdot 5$ & $45 \cdot 9$ & $43 \cdot 9$ \\
\hline & $100 \cdot 0$ & $5 \cdot 8$ & $15 \cdot 3$ & $32 \cdot 4$ & $46 \cdot 5$ & & \\
\hline \multirow[t]{3}{*}{ Total } & 6,471 & 794 & 2,456 & 2,084 & 1,137 & & \\
\hline & $7,387 \cdot 5$ & $952 \cdot 8$ & $2,733 \cdot 2$ & $2,246 \cdot 0$ & $1,455 \cdot 6$ & $34 \cdot 3$ & $33 \cdot 0$ \\
\hline & $100 \cdot 0$ & $12 \cdot 9$ & $37 \cdot 0$ & $30 \cdot 4$ & $19 \cdot 7$ & & \\
\hline
\end{tabular}

cohort born 1891-1900 the same group represented $79.7 \%$ of the cohort (Table 23, Fig. 24).

\subsubsection{DISTRIBUTION BY TYPE}

\section{According to sex and place}

In the high frequency areas during the observation period, type index was $64 \cdot 8$ (Table 24); 65.4 in males and 64.1 in females. Variations between regions and counties were insignificant; in the northern region, type index was $66 \cdot 9$, in the middle region $66 \cdot 0$, and in the two northern counties of the southern region, the counties of Sogn \& Fjordane and Hordaland, type index was 64.2. However, in the most southern county of the high frequency areas, the county of Rogaland, type index was 56.9 . 


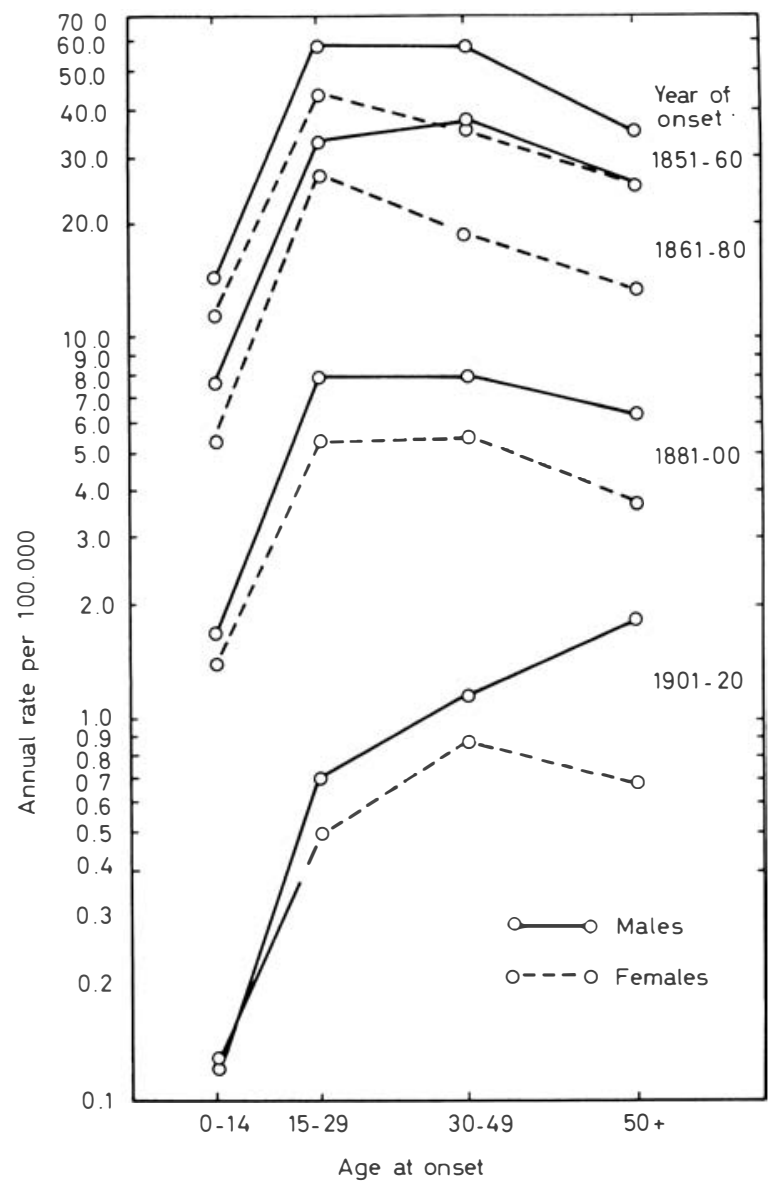

Figure 20. Incidence rates of leprosy in Norway, high frequency areas, 1851-1920. Age- and sex-specific rates by year of onset. (The National Leprosy Registry of Norway.)

In the low frequency areas during the same period, type index was 45.5 (Table 24); $49 \cdot 3$ in males and 40.0 in females. Highest type index in these areas, $47 \cdot 5$, was found in the county with the highest total incidence, Hedmark. Type index in the other counties of the low frequency areas was 44.7 (vide also Table 38).

\section{According to sex and year of onset}

Type index of 543 males and 537 females with known type of leprosy and with year of onset before 1851 , was 55.3 and 47.0 respectively (Table 24 ). Type index of 3,861 males and 2,766 females with known type of leprosy and with year of onset after 1850, was 65.1 and 63.6 respectively (Table $24)$. For the same 6,627 patients with type 1,2 and 3 respectively, number of males per 100 females was $138 \cdot 8,160 \cdot 0$ and $130 \cdot 4$. 
64

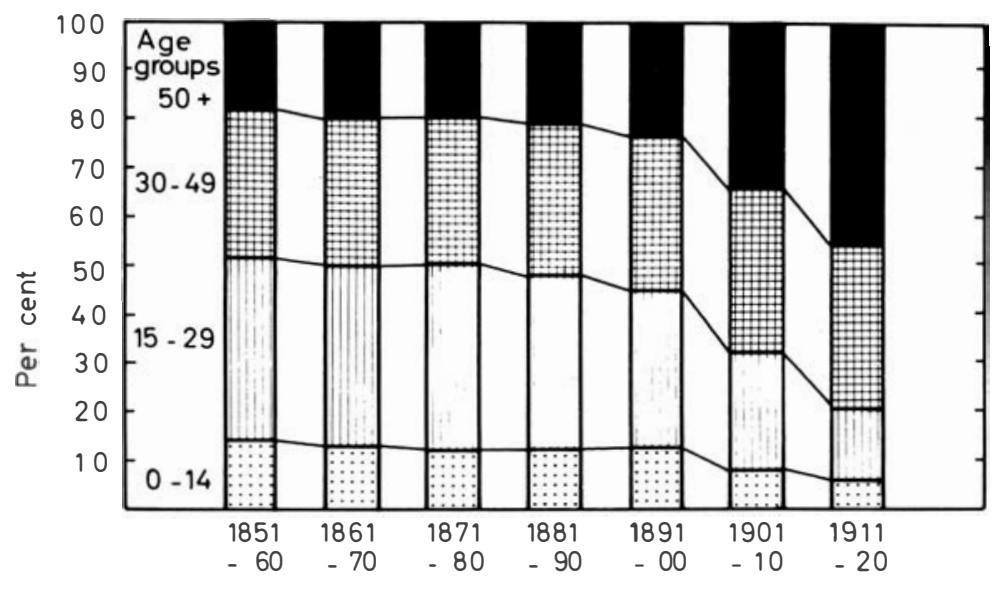

Calendar year of onset

Figure 21. Relative frequencies in Norway, high frequency areas, 1851-1920, of leprosy cases in different age groups by year of onset. Relative frequencies based on age- and sexspecific incidence rates and a standard population. (The National Leprosy Registry of Norway.)

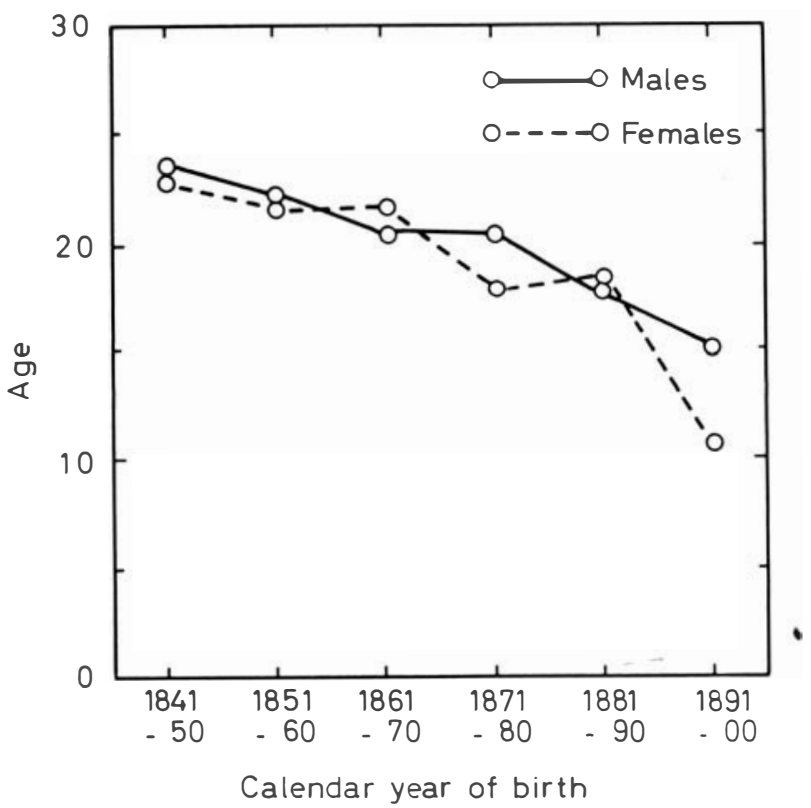

Figure 22. Mean age at onset of leprosy in Norway, high frequency areas, 1851-1920, by sex and year of birth. (The National Leprosy Registry of Norway.) 


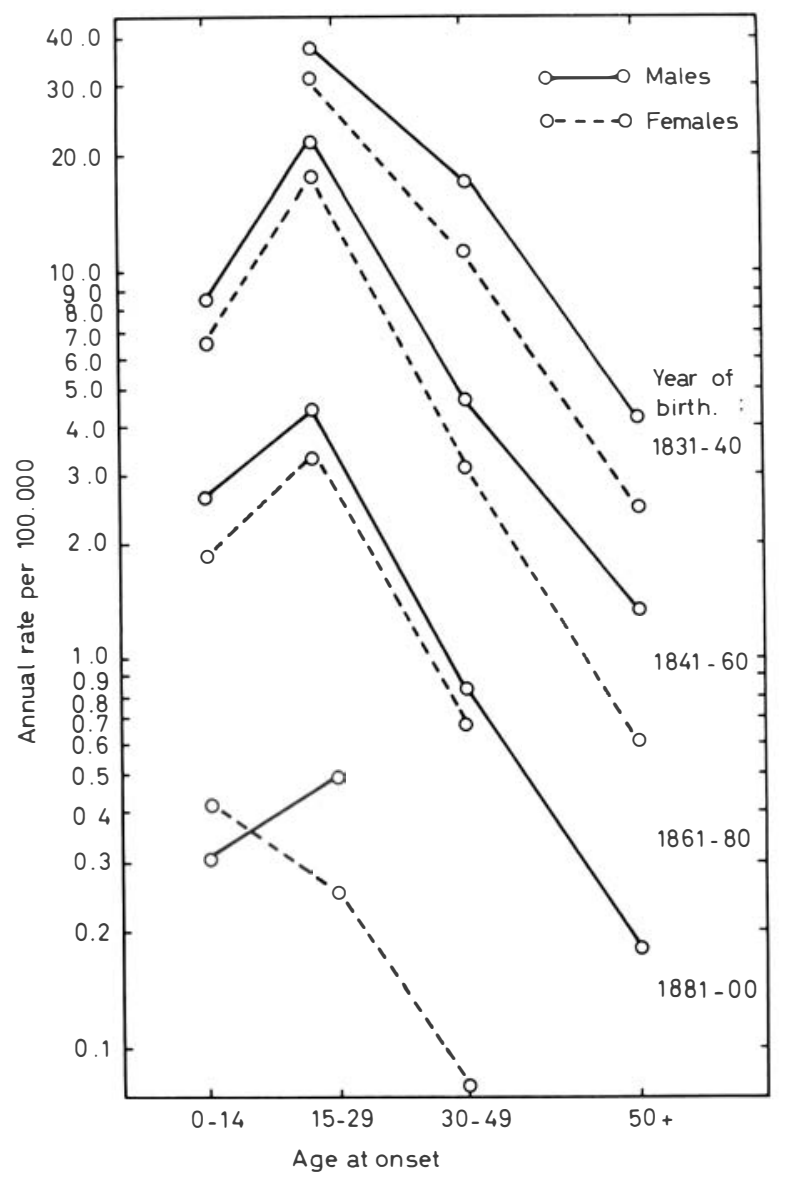

Figure 23. Incidence rates of leprosy in Norway, high frequency areas, 1851-1920. Age- and sex-specific rates by year of birth. (The National Leprosy Registry of Norway.)

During the observation period from 1851 to 1890 type index in both sexes ranged between 62.0 and 66.5 (Table 25, Fig. 25); however, males at a somewhat higher level than females. After 1890 type index of males increased, while the index of females decreased after a peak in the decade 1891-1900. Similar trends occurred in all parts of the country.

\section{According to sex and year of birth}

Studied in consecutive birth cohorts, sex-specific type index of patients born between 1841 and 1900 ranged from $64 \cdot 8$ to $70 \cdot 7$, except the decade $1871-80$ (Table 26, Fig. 26). Type index of male patients born in this decade was $76 \cdot 3$. 
Table 22. New cases of leprosy in Norway, high frequency areas, 1851-1920 by year of birth, with sex ratio based on annual incidence rates per 100,000, according to age and sex. (The National Leprosy Registry of Norway)

\begin{tabular}{|c|c|c|c|c|c|c|c|c|}
\hline \multirow[b]{2}{*}{$\begin{array}{l}\text { Year of } \\
\text { birth }\end{array}$} & \multicolumn{2}{|c|}{$0-14$ years } & \multicolumn{2}{|c|}{$15-29$ years } & \multicolumn{2}{|c|}{$30-49$ years } & \multicolumn{2}{|c|}{$50+$ years } \\
\hline & $\begin{array}{c}\text { (No.) } \\
\text { (Incidence) }\end{array}$ & Ratio & $\begin{array}{c}\text { (No.) } \\
\text { (Incidence) }\end{array}$ & Ratio & $\begin{array}{c}\text { (No.) } \\
\text { (Incidence) }\end{array}$ & Ratio & $\begin{array}{c}\text { (No.) } \\
\text { (Incidence) }\end{array}$ & Ratio \\
\hline \multicolumn{9}{|l|}{ Male } \\
\hline $1831-1840$ & - & - & $\begin{array}{l}474 \\
37 \cdot 4\end{array}$ & $117 \cdot 9$ & $\begin{array}{l}265 \\
17 \cdot 2\end{array}$ & $152 \cdot 0$ & $\begin{array}{l}39 \\
4 \cdot 3\end{array}$ & $171 \cdot 8$ \\
\hline $1841-1860$ & $\begin{array}{l}317 \\
8 \cdot 7\end{array}$ & $131 \cdot 5$ & $\begin{array}{l}597 \\
21 \cdot 9\end{array}$ & $123 \cdot 0$ & $\begin{array}{l}175 \\
4 \cdot 7\end{array}$ & $149 \cdot 2$ & $\begin{array}{l}31 \\
1 \cdot 4\end{array}$ & $223 \cdot 0$ \\
\hline $1861-1880$ & $\begin{array}{l}120 \\
2 \cdot 6\end{array}$ & $140 \cdot 9$ & $\begin{array}{r}134 \\
4 \cdot 4\end{array}$ & $132 \cdot 2$ & $\begin{array}{l}32 \\
0 \cdot 8\end{array}$ & $120 \cdot 3$ & $\begin{array}{c}5 \\
0 \cdot 18\end{array}$ & - \\
\hline $1881-1900$ & $\begin{array}{c}17 \\
0 \cdot 3 \\
\end{array}$ & $73 \cdot 8$ & $\begin{array}{c}18 \\
0 \cdot 5\end{array}$ & $166 \cdot 7$ & 0 & - & 0 & - \\
\hline \multicolumn{9}{|l|}{ Female } \\
\hline $1831-1840$ & - & & $\begin{array}{l}414 \\
31 \cdot 7\end{array}$ & & $\begin{array}{l}181 \\
11 \cdot 3\end{array}$ & & $\begin{array}{l}26 \\
2 \cdot 5\end{array}$ & \\
\hline $1841-1860$ & $\begin{array}{l}233 \\
6 \cdot 6\end{array}$ & & $\begin{array}{l}512 \\
17 \cdot 8\end{array}$ & & $\begin{array}{c}125 \\
3 \cdot 2\end{array}$ & & $\begin{array}{l}16 \\
0 \cdot 6\end{array}$ & \\
\hline $1861-1880$ & $\begin{array}{l}82 \\
1 \cdot 9\end{array}$ & & $\begin{array}{r}115 \\
3 \cdot 4\end{array}$ & & $\begin{array}{l}28 \\
0 \cdot 7\end{array}$ & & $\begin{array}{l}0 \\
-\end{array}$ & \\
\hline 1881-1900 & $\begin{array}{l}22 \\
0 \cdot 4\end{array}$ & & $\begin{array}{l}10 \\
0 \cdot 3\end{array}$ & & $\begin{array}{l}4 \\
0 \cdot 1\end{array}$ & & $\begin{array}{l}0 \\
-\end{array}$ & \\
\hline
\end{tabular}




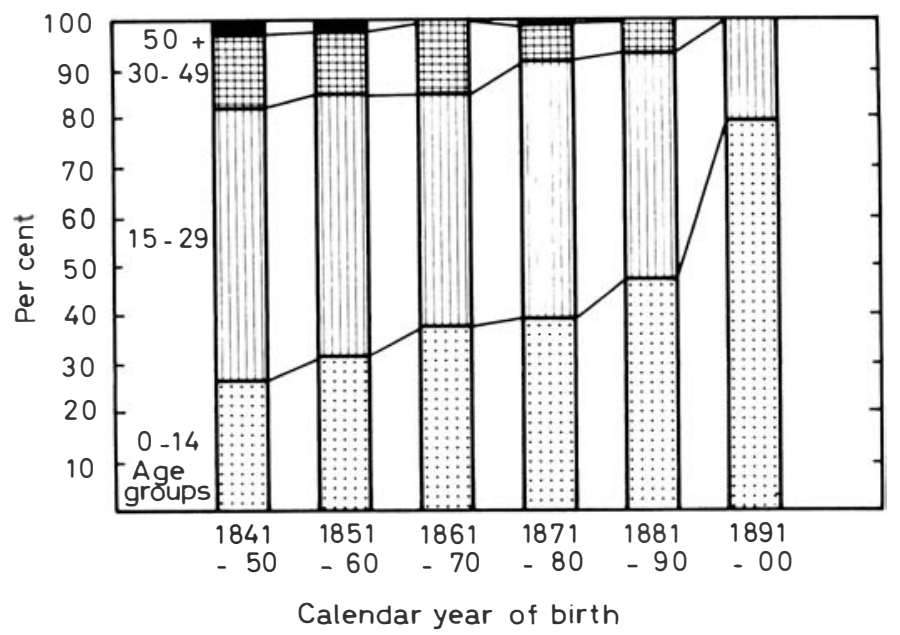

Figure 24. Relative frequencies in Norway, high frequency areas, 1851-1920, of leprosy cases in different age groups, by year of birth. Relative frequencies based on age- and sexspecific incidence rates and a standard population. (The National Leprosy Registry of Norway.)

Table 23. New cases of leprosy in Norway, high frequency areas 1851-1920 by year of birth, actual registered number $\left(n_{1}\right)$ and number calculated on the basis of a standard population and age- and sex-specific incidence rates $\left(n_{2}\right)$, with mean age at onset. (The National Leprosy Registry of Norway)

\begin{tabular}{|c|c|c|c|c|c|c|c|}
\hline \multirow[b]{2}{*}{$\begin{array}{c}\text { Year of } \\
\text { birth }\end{array}$} & \multicolumn{5}{|c|}{ Total } & \multirow[b]{2}{*}{$\begin{array}{l}\text { Male } \\
\text { (mean } \\
\text { age at } \\
\text { onset) }\end{array}$} & \multirow[b]{2}{*}{$\begin{array}{c}\text { Female } \\
\text { (mean } \\
\text { age at } \\
\text { onset) }\end{array}$} \\
\hline & $\begin{array}{l}\text { Total } \\
\left(n_{1}\right) \\
\left(n_{2}\right) \\
(\%)\end{array}$ & $\begin{array}{c}0-14 \text { yrs } \\
\left(n_{1}\right) \\
\left(n_{2}\right) \\
(\%)\end{array}$ & $\begin{array}{c}15-29 \text { yrs } \\
\left(n_{1}\right) \\
\left(n_{2}\right) \\
(\%)\end{array}$ & $\begin{array}{c}30-49 \text { yrs } \\
\left(n_{1}\right) \\
\left(n_{2}\right) \\
(\%)\end{array}$ & $\begin{array}{c}50+y r s \\
\left(n_{1}\right) \\
\left(n_{2}\right) \\
(\%)\end{array}$ & & \\
\hline \multirow[t]{3}{*}{$1841-1850$} & 1,210 & 302 & 681 & 198 & 29 & & \\
\hline & $1,313 \cdot 3$ & $346 \cdot 7$ & $732 \cdot 4$ & $202 \cdot 5$ & $31 \cdot 7$ & $23 \cdot 1$ & $22 \cdot 9$ \\
\hline & $100 \cdot 0$ & $26 \cdot 4$ & $55 \cdot 8$ & $15 \cdot 4$ & $2 \cdot 4$ & & \\
\hline \multirow[t]{3}{*}{$1851-1860$} & 796 & 248 & 428 & 102 & 18 & & \\
\hline & $796 \cdot 0$ & $248 \cdot 0$ & $428 \cdot 0$ & $102 \cdot 0$ & $18 \cdot 0$ & $22 \cdot 1$ & $21 \cdot 7$ \\
\hline & $100 \cdot 0$ & $31 \cdot 2$ & $53 \cdot 7$ & $12 \cdot 8$ & $2 \cdot 3$ & & \\
\hline \multirow{3}{*}{$1861-1870$} & 350 & 134 & 164 & 49 & 3 & & \\
\hline & $318 \cdot 8$ & $118 \cdot 4$ & $151 \cdot 2$ & $46 \cdot 9$ & $2 \cdot 3$ & $20 \cdot 5$ & $21 \cdot 6$ \\
\hline & $100 \cdot 0$ & $37 \cdot 2$ & $47 \cdot 4$ & $14 \cdot 7$ & $0 \cdot 7$ & & \\
\hline \multirow[t]{3}{*}{$1871-1880$} & 166 & 68 & 85 & 11 & 2 & & \\
\hline & $144 \cdot 5$ & $56 \cdot 3$ & $76 \cdot 6$ & $10 \cdot 0$ & $1 \cdot 6$ & $20 \cdot 5$ & $18 \cdot 0$ \\
\hline & $100 \cdot 0$ & $39 \cdot 0$ & $53 \cdot 0$ & $6 \cdot 9$ & $1 \cdot 1$ & & \\
\hline \multirow[t]{3}{*}{$1881-1890$} & 60 & 30 & 26 & 4 & 0 & & \\
\hline & $47 \cdot 5$ & $22 \cdot 6$ & $21 \cdot 7$ & $3 \cdot 2$ & & $17 \cdot 6$ & $18 \cdot 5$ \\
\hline & $100 \cdot 0$ & $47 \cdot 6$ & $45 \cdot 7$ & $6 \cdot 8$ & & & \\
\hline \multirow{3}{*}{$1891-1900$} & 11 & 9 & 2 & 0 & 0 & & \\
\hline & $7 \cdot 7$ & $6 \cdot 1$ & $1 \cdot 6$ & & & $15 \cdot 1$ & $10 \cdot 7$ \\
\hline & $100 \cdot 0$ & $79 \cdot 7$ & $20 \cdot 3$ & & & & \\
\hline
\end{tabular}


Table 24. Leprosy cases in Norway with type index, by sex, residential district and year of onset. (The National Leprosy Registry of Norway)

\begin{tabular}{|c|c|c|c|c|c|c|c|c|c|c|}
\hline \multirow[b]{3}{*}{$\begin{array}{c}\text { Year of } \\
\text { onset }\end{array}$} & \multicolumn{2}{|c|}{ Total } & \multicolumn{4}{|c|}{ Sex } & \multicolumn{4}{|c|}{ Residential district } \\
\hline & \multirow[b]{2}{*}{ No. } & \multirow[b]{2}{*}{$\begin{array}{l}\text { Type } \\
\text { index }\end{array}$} & \multicolumn{2}{|c|}{ Male } & \multicolumn{2}{|c|}{ Female } & \multicolumn{2}{|c|}{$\begin{array}{l}\text { High frequency } \\
\text { areas }\end{array}$} & \multicolumn{2}{|c|}{$\begin{array}{c}\text { Low frequency } \\
\text { areas }\end{array}$} \\
\hline & & & No. & $\begin{array}{l}\text { Type } \\
\text { index }\end{array}$ & No. & $\begin{array}{l}\text { Type } \\
\text { index }\end{array}$ & No. & $\begin{array}{l}\text { Type } \\
\text { index }\end{array}$ & No. & $\begin{array}{l}\text { Type } \\
\text { index }\end{array}$ \\
\hline-1850 & 1,080 & $51 \cdot 1$ & 543 & $55 \cdot 3$ & 537 & $47 \cdot 0$ & 1,057 & $51 \cdot 7$ & 23 & $22 \cdot 2$ \\
\hline $1851-1920$ & 6,613 & $64 \cdot 4$ & 3,850 & $65 \cdot 1$ & 2,763 & $63 \cdot 6$ & 6,473 & $64 \cdot 8$ & 140 & $45 \cdot 5$ \\
\hline $\begin{array}{c}\text { Subtotal } \\
\text { Type }\end{array}$ & 8,027 & $62 \cdot 7$ & 4,561 & 63.9 & 3,466 & $60 \cdot 1$ & 7,848 & $62 \cdot 6$ & 179 & $44 \cdot 1$ \\
\hline unknown & 204 & & 107 & & 97 & & 198 & & 6 & \\
\hline Total & 8,231 & & 4,668 & & 3,563 & & 8,046 & & 185 & \\
\hline
\end{tabular}


Table 25. New cases of leprosy in Norway 1851-1920 with type index, by age, sex and year of onset. (The National Leprosy Registry of Norway)

\begin{tabular}{|c|c|c|c|c|c|c|c|c|c|c|}
\hline \multirow[b]{2}{*}{$\begin{array}{c}\text { Year of } \\
\text { onset }\end{array}$} & \multicolumn{2}{|c|}{ Total } & \multicolumn{2}{|c|}{$0-14$ years } & \multicolumn{2}{|c|}{$15-29$ years } & \multicolumn{2}{|c|}{$30-49$ years } & \multicolumn{2}{|c|}{$50+$ years } \\
\hline & No. & $\begin{array}{l}\text { Type } \\
\text { index }\end{array}$ & No. & $\begin{array}{l}\text { Type } \\
\text { index }\end{array}$ & No. & $\begin{array}{l}\text { Type } \\
\text { index }\end{array}$ & No. & $\begin{array}{l}\text { Type } \\
\text { index }\end{array}$ & No. & $\begin{array}{l}\text { Type } \\
\text { index }\end{array}$ \\
\hline \multicolumn{11}{|l|}{ Male } \\
\hline $1851-1860$ & 1,324 & $63 \cdot 4$ & 174 & $62 \cdot 0$ & 511 & $67 \cdot 1$ & 447 & $64 \cdot 2$ & 192 & $53 \cdot 2$ \\
\hline $1861-1880$ & 1,907 & $65 \cdot 4$ & 225 & $69 \cdot 7$ & 648 & $68 \cdot 0$ & 696 & $67 \cdot 4$ & 338 & $53 \cdot 2$ \\
\hline $1881-1900$ & 495 & $66 \cdot 5$ & 58 & $66 \cdot 0$ & 170 & $71 \cdot 2$ & 149 & $70 \cdot 2$ & 118 & $55 \cdot 1$ \\
\hline $1901-1920$ & 92 & $72 \cdot 2$ & 6 & $83 \cdot 3$ & 23 & $68 \cdot 2$ & 24 & $87 \cdot 5$ & 39 & $63 \cdot 2$ \\
\hline Total & 3,818 & $64 \cdot 5$ & 463 & $66 \cdot 7$ & 1,352 & $68 \cdot 1$ & 1,316 & $67 \cdot 1$ & 687 & $54 \cdot 2$ \\
\hline \multicolumn{11}{|l|}{ Female } \\
\hline $1851-1860$ & 997 & $63 \cdot 9$ & 135 & $64 \cdot 5$ & 412 & $67 \cdot 7$ & 281 & $63 \cdot 0$ & 169 & $55 \cdot 7$ \\
\hline $1861-1880$ & 1,314 & $62 \cdot 7$ & 152 & $69 \cdot 7$ & 571 & $68 \cdot 0$ & 377 & $67 \cdot 4$ & 214 & $53 \cdot 2$ \\
\hline $1881-1900$ & 377 & $67 \cdot 9$ & 46 & $78 \cdot 6$ & 129 & $71 \cdot 2$ & 122 & $70 \cdot 2$ & 80 & $55 \cdot 1$ \\
\hline $1901-1920$ & 67 & $51 \cdot 6$ & 6 & $66 \cdot 6$ & 18 & $68 \cdot 8$ & 24 & $47 \cdot 8$ & 19 & $36 \cdot 8$ \\
\hline Total & 2,755 & $65 \cdot 1$ & 339 & $68 \cdot 8$ & 1,130 & $68 \cdot 2$ & 804 & $61 \cdot 2$ & 482 & $52 \cdot 9$ \\
\hline \multicolumn{11}{|l|}{ Total } \\
\hline $1851-1860$ & 2,321 & $63 \cdot 6$ & 309 & $63 \cdot 1$ & 923 & $67 \cdot 3$ & 728 & $63 \cdot 8$ & 361 & $54 \cdot 4$ \\
\hline $1861-1880$ & 3,221 & $64 \cdot 3$ & 377 & $69 \cdot 6$ & 1,219 & $68 \cdot 0$ & 1,073 & $64 \cdot 8$ & 552 & $50 \cdot 8$ \\
\hline $1881-1900$ & 872 & $67 \cdot 1$ & 104 & $71 \cdot 7$ & 299 & $70 \cdot 8$ & 271 & $67 \cdot 0$ & 198 & $59 \cdot 4$ \\
\hline $1901-1920$ & 159 & $63 \cdot 6$ & 12 & $75 \cdot 0$ & 41 & $68 \cdot 4$ & 48 & $68 \cdot 1$ & 58 & $54 \cdot 4$ \\
\hline Total & 6,573 & $63 \cdot 6$ & 802 & $67 \cdot 6$ & 2,482 & $68 \cdot 1$ & 2,120 & $64 \cdot 8$ & 1,169 & $53 \cdot 7$ \\
\hline
\end{tabular}




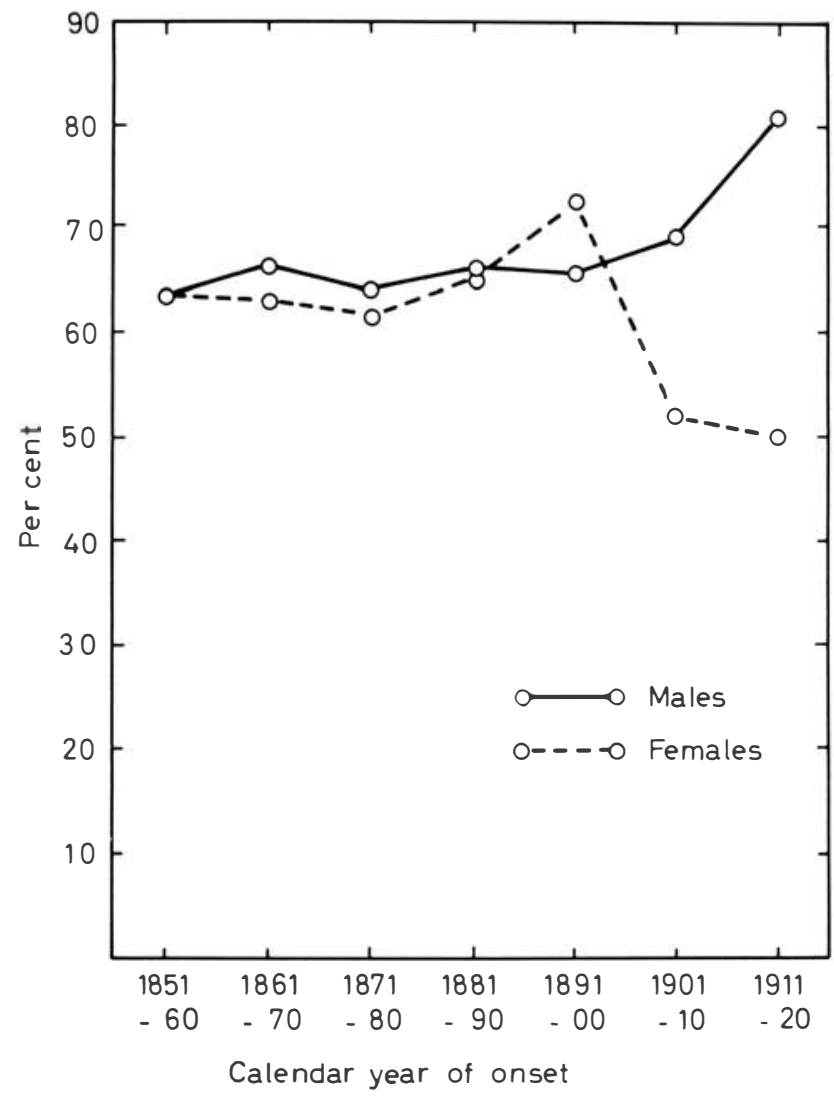

Figure 25. Type index of leprosy in Norway, 1851-1920, by sex and year of onset. (The National Leprosy Registry of Norway.)

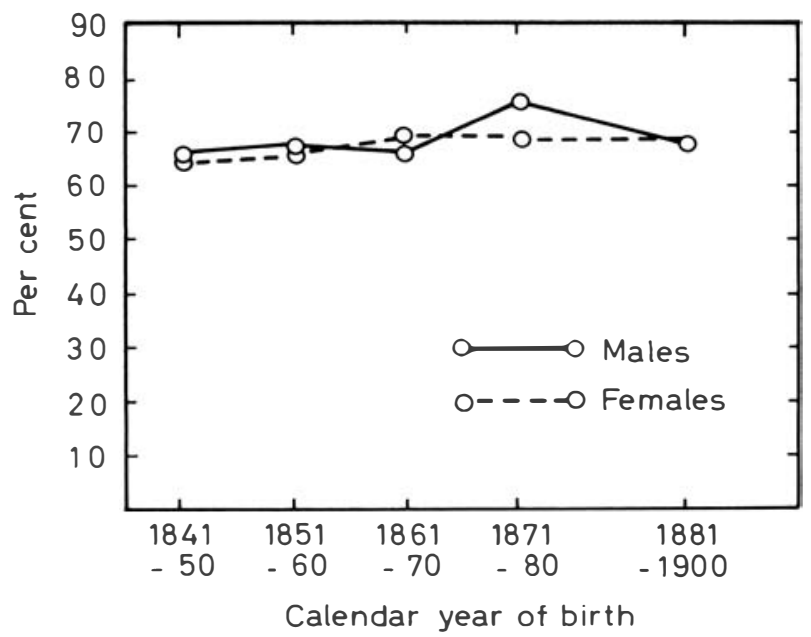

Figure 26. Type index of leprosy in Norway, 1851-1920, by sex and year of birth. (The National Leprosy Registry of Norway.) 
Table 26. New cases of leprosy in Norway 1851-1920 with type index, by age, sex and year of birth. (The National Leprosy Registry of Norway)

\begin{tabular}{|c|c|c|c|c|c|c|c|c|c|c|}
\hline \multirow[b]{2}{*}{$\begin{array}{c}\text { Year of } \\
\text { birth }\end{array}$} & \multicolumn{2}{|c|}{ Total } & \multicolumn{2}{|c|}{$0-14$ years } & \multicolumn{2}{|c|}{$15-29$ years } & \multicolumn{2}{|c|}{$30-49$ years } & \multicolumn{2}{|c|}{$50+$ years } \\
\hline & No. & $\begin{array}{l}\text { Type } \\
\text { index }\end{array}$ & No. & $\begin{array}{l}\text { Type } \\
\text { index }\end{array}$ & No. & $\begin{array}{l}\text { Type } \\
\text { index }\end{array}$ & No. & $\begin{array}{l}\text { Type } \\
\text { index }\end{array}$ & No. & $\begin{array}{l}\text { Type } \\
\text { index }\end{array}$ \\
\hline \multicolumn{11}{|l|}{ Male } \\
\hline $1831-1840$ & & & - & & 475 & $68 \cdot 1$ & 273 & $65 \cdot 8$ & 39 & $35 \cdot 3$ \\
\hline $1841-1860$ & 1,147 & $67 \cdot 1$ & 316 & $65 \cdot 8$ & 616 & $66 \cdot 3$ & 181 & $71 \cdot 7$ & 34 & $70 \cdot 6$ \\
\hline $1861-1880$ & 300 & $71 \cdot 2$ & 122 & $67 \cdot 9$ & 139 & $70 \cdot 9$ & 34 & $81 \cdot 8$ & 5 & $80 \cdot 0$ \\
\hline $1881-1900$ & 44 & $68 \cdot 3$ & 18 & $70 \cdot 6$ & 24 & $65 \cdot 2$ & 2 & - & 0 & - \\
\hline \multicolumn{11}{|l|}{ Female } \\
\hline $1831-1840$ & & & - & & 418 & $67 \cdot 6$ & 183 & $63 \cdot 9$ & 29 & $64 \cdot 3$ \\
\hline $1841-1860$ & 901 & $66 \cdot 0$ & 238 & $67 \cdot 0$ & 514 & $67 \cdot 5$ & 131 & $62 \cdot 0$ & 18 & $44 \cdot 4$ \\
\hline $1861-1880$ & 228 & $71 \cdot 0$ & 82 & $75 \cdot 3$ & 118 & $71 \cdot 2$ & 28 & $57 \cdot 7$ & 0 & $=$ \\
\hline $1881-1900$ & 43 & $67 \cdot 6$ & 26 & $68 \cdot 2$ & 13 & $72 \cdot 7$ & 4 & - & 0 & - \\
\hline
\end{tabular}




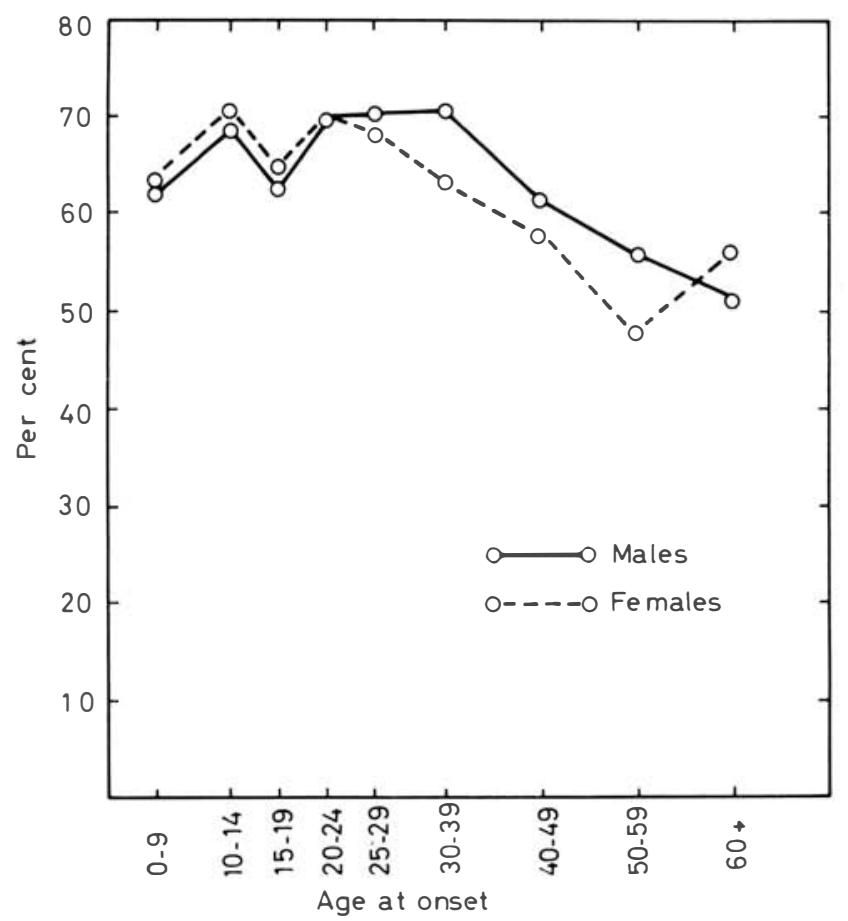

Figure 27. Type index of leprosy in Norway, 1851-1920, by sex and age at onset. (The National Leprosy Registry of Norway.)

\section{According to sex and age}

For patients with type 1,2 and 3 mean age at onset (based on crude number of patients) was $31.9,34.3$ and 35.7 years, respectively. However, type index varied considerably in different age groups (Table 25, Fig. 27). In males, the highest type index was found in the age group 20-39 years; in females a maximum was found in the age group 20-24 years. In both sexes, type index declined towards a lower and also towards a higher age. However, in the higher age groups, type index was considerably lower in females than in males.

\section{According to sex and age by year of onset}

When sex-specific type index according to age was calculated in subsequent decades, it appeared that an evident maximum in adolescents was present only between 1851 and 1860 (Table 25, Fig. 28). In this decade, small differences between male and female type index were found.

During the next decades, type index in the age group 15-29 years appeared to remain at a constant level; in both sexes between $67 \cdot 1$ and $70 \cdot 2$ (Table 25, Fig. 29). However, particularly in the age groups over 30 years, increasing differences between male and female type index were observed towards the end of 


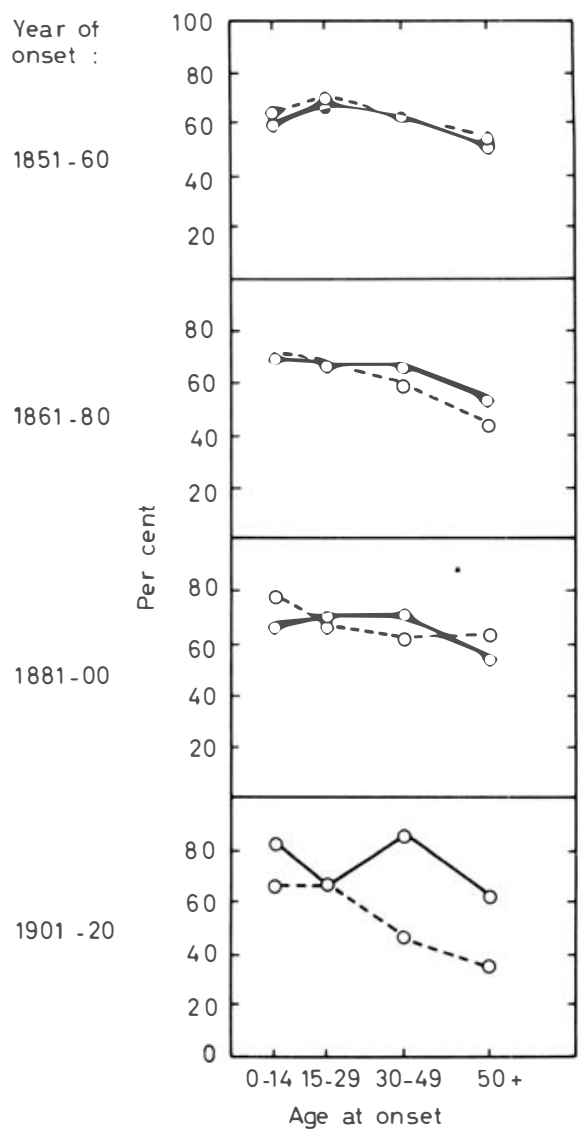

Figure 28. Type index of leprosy in Norway, 1851-1920, by age, sex and year of onset. (The National Leprosy Registry of Norway.)

the observation period, highest type index being observed in males (Fig. 28). Accordingly, type index in all age groups in males, except 15-29 years, increased during the observation period (Fig. 29), and particularly towards the end of the observation period. This trend was not found in females. On the contrary, towards the end of the observation period, female type index declined in all age groups except 15-29 years.

\subsubsection{MOVEMENTS IN THE DIAGNOSTIC SPECTRUM}

When nothing else is indicated, type, in the present study, refers to the chronologically last classification of a case (vide 2.5.3.). However, in 483 (5.9\%) cases, the last diagnosis was not identical to the first (Table 27).

In $3,855(91.6 \%)$ of 4,209 cases primarily diagnosed as type 1 , no movements were registered, while in $354(8.4 \%)(208+146)$ cases, movements towards type 2 and 3 were registered. However, the relative frequency of 


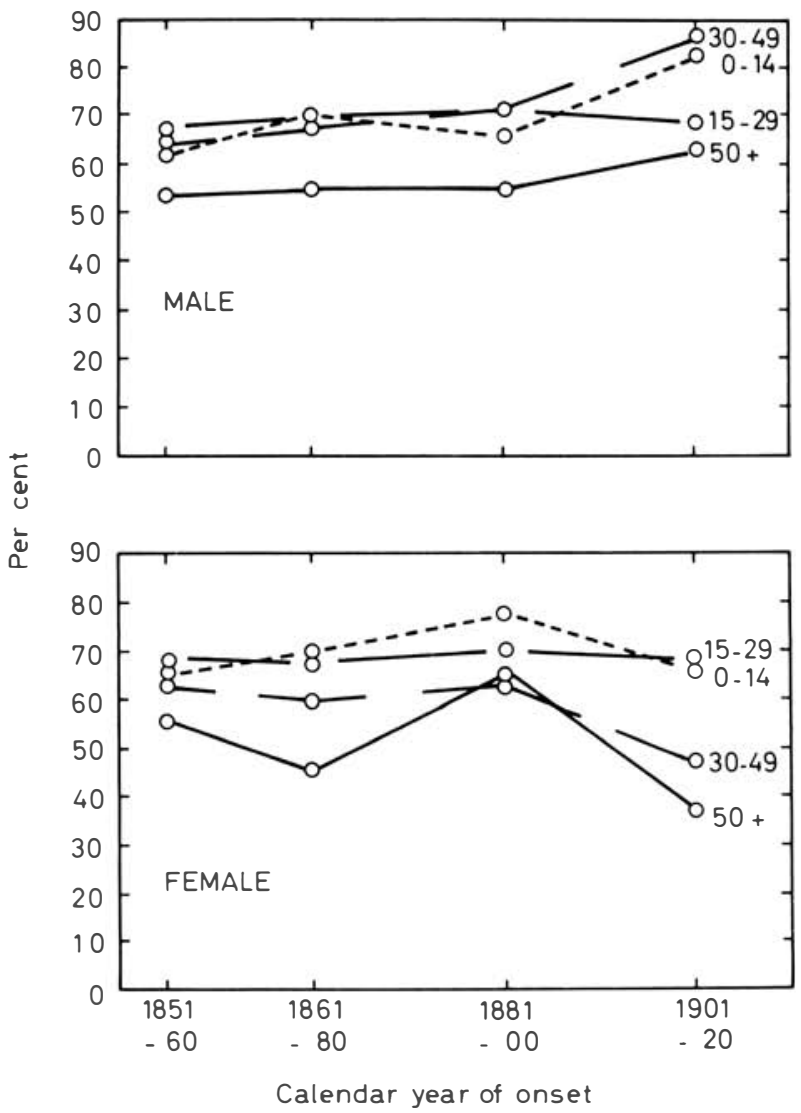

Figure 29. Type index of leprosy in Norway, 1851-1920, by age and year of onset in males and females. (The National Leprosy Registry of Norway.)

movements towards 2 and 3 did not correspond to the relative frequencies of all type 2 and type 3 cases registered (expected values); relatively more cases moved towards 2 , the intermediate type. Of 354 cases, 208 moved towards type 2 and 146 towards type 3, against expected values of 126.4 and $227 \cdot 6$, respectively.

In 1,357 cases primarily diagnosed as type 2, $290(21.4 \%)$ movements were registered, and in accordance with expected values; 180 cases moved towards type 1 and 110 towards type 3 , while expected values were 183.3 and 106.7 respectively.

In 2,447 cases primarily diagnosed as type 3, 219 (8.9\%) movements were registered, and with the same trend as found for the type 1 cases; 148 cases moved towards type 1 and 71 towards type 2, against expected values of 165.6 and $53 \cdot 4$ respectively. 
Table 27. Leprosy cases according to first and last diagnosis with respect to the type of disease. (The National Leprosy Registry of Norway)

\begin{tabular}{|c|c|c|c|c|c|c|c|c|c|c|}
\hline \multirow[b]{3}{*}{$\begin{array}{c}\text { Last } \\
\text { diagnosis }\end{array}$} & \multicolumn{10}{|c|}{ First diagnosis } \\
\hline & \multicolumn{2}{|c|}{ Type 1} & \multicolumn{2}{|c|}{ Type 2} & \multicolumn{2}{|c|}{ Type 3} & \multicolumn{2}{|c|}{ Unknown } & \multicolumn{2}{|c|}{ Total } \\
\hline & $\begin{array}{c}\text { (No.) } \\
(\%)\end{array}$ & $(\%)$ & $\begin{array}{c}\text { (No.) } \\
(\%)\end{array}$ & $(\%)$ & $\begin{array}{c}\text { (No.) } \\
(\%)\end{array}$ & $(\%)$ & $\begin{array}{c}\text { (No.) } \\
(\%)\end{array}$ & $(\%)$ & $\begin{array}{c}\text { (No.) } \\
(\%)\end{array}$ & $(\%)$ \\
\hline Type 1 & $\begin{array}{l}3,855 \\
92 \cdot 1\end{array}$ & $91 \cdot 6$ & $\begin{array}{r}180 \\
4 \cdot 3\end{array}$ & $13 \cdot 3$ & $\begin{array}{r}148 \\
3 \cdot 5\end{array}$ & $6 \cdot 0$ & $\begin{array}{l}4 \\
0 \cdot 1\end{array}$ & $1 \cdot 8$ & $\begin{array}{r}4,187 \\
100 \cdot 0\end{array}$ & $50 \cdot 8$ \\
\hline Type 2 & $\begin{array}{l}208 \\
15 \cdot 4\end{array}$ & $4 \cdot 9$ & $\begin{array}{r}1,067 \\
79 \cdot 0\end{array}$ & $78 \cdot 6$ & $\begin{array}{l}71 \\
5 \cdot 3\end{array}$ & $2 \cdot 9$ & $\begin{array}{l}4 \\
0 \cdot 3\end{array}$ & $1 \cdot 8$ & $\begin{array}{l}1,350 \\
100 \cdot 0\end{array}$ & $16 \cdot 4$ \\
\hline Type 3 & $\begin{array}{r}146 \\
5 \cdot 9\end{array}$ & $3 \cdot 5$ & $\begin{array}{r}110 \\
4 \cdot 4\end{array}$ & $8 \cdot 1$ & $\begin{array}{r}2,228 \\
89 \cdot 5\end{array}$ & $91 \cdot 1$ & $\begin{array}{l}6 \\
0 \cdot 2\end{array}$ & $2 \cdot 8$ & $\begin{array}{l}2,490 \\
100 \cdot 0\end{array}$ & $30 \cdot 3$ \\
\hline Unknown & 0 & - & 0 & - & 0 & - & $\begin{array}{l}204 \\
100 \cdot 0\end{array}$ & $93 \cdot 6$ & $\begin{array}{l}204 \\
100 \cdot 0\end{array}$ & $2 \cdot 5$ \\
\hline Total & $\begin{array}{r}4,209 \\
51 \cdot 2\end{array}$ & $100 \cdot 0$ & $\begin{array}{r}1,357 \\
16 \cdot 5\end{array}$ & $100 \cdot 0$ & $\begin{array}{r}2,447 \\
29 \cdot 7\end{array}$ & $100 \cdot 0$ & $\begin{array}{r}218 \\
2 \cdot 6\end{array}$ & $100 \cdot 0$ & $\begin{array}{r}8,231 \\
100 \cdot 0\end{array}$ & $100 \cdot 0$ \\
\hline
\end{tabular}




\subsubsection{COMMENTS}

The patient group with year of onset before 1851, had a lower proportion of males to females, a lower mean age at onset, and a lower type index than the other patients. Compared with time trends observed after 1851, the low values might reflect a continuation of these trends backwards. However, data collected in the prevalence survey, which represented the initial phase in the registration work, are obviously not completely comparable with data collected by continuous registration. The findings, for a greater part, are most likely due to higher mortality rates in males, elderly patients and patients with type 1 of leprosy.

The conspicuous dip in the curve of sex ratio by time (Fig. 15) registered in the decade 1891-1900, was most likely due to a lower incidence rate in males than anticipated and not the opposite, a higher rate in females. This seems to emerge from the curves of sex-specific incidence rates (Fig. 14). The dip was so marked that it was hardly attributable to temporary variations in exposure or susceptibility in males.

However, the finding might be related to the emigration to the USA provided that there was an excess of males among the emigrants, that a maximum in emigration rates occurred in the previous decade (1881-90), and that the emigrants represented a high risk group with a high incidence rate, i.e. high 'potential incidence rate', if not removed from their local society.

Calculated on the basis of the official statistics (NOS, 1921) as number of males per 100 females, male excess among emigrants in the age group 5-30 years, the group probably most threatened by exposure to infection, increased from 118.7 in the decade $1856-65$ to 184.7 in the decade $1895-1905$. In the counties with the highest incidence rates, the emigration rates reached a maximum of 845 emigrants per 100,000 per year in the decade 1881-90.

On the basis of two assumptions, estimation of the number of 'potential patients', removed by emigration, was possible. First, that sex ratio, in the case of no emigration, should be on the level found in the previous and subsequent decades; viz. 150. Second, that the sex ratio, based on sex-specific 'potential incidence rates' among emigrants, should be on the same level as the sex ratio in the age group 15-49 years during the period 1861-80; viz. 162. Based on these assumptions, 'potential incidence rates' of males and females among emigrants were found to be 26.9 and 16.6 respectively. Most of the emigrants during the period 1856-85 had their homes in the southern region; number of emigrants from the southern and middle regions were respectively 2.56 and 1.43 times higher than number of emigrants from the northern region. In the southern region, emigration rates were highest in the county of Sogn \& Fjordane. In this county, sex-specific incidence rates of the age groups 15-49 years in 1881-90, varied between 17 and 22. Accordingly, 'potential incidence rates' among emigrants was of the same level as comparable incidence rates of high risk groups. 
Obviously, emigration prior to the decade 1881-90, though of minor extent, must have influenced incidence rates. However, possible adjustments made on this basis were considered questionable.

However, emigration most likely influenced incidence rates more directly too. There are indications (vide 2.3.3.) that some patients emigrated without being registered; accordingly some of the 'potential patients' appeared to be manifest cases. Apparently, most of these patients must have been affected by a benign type of leprosy (type 3). According to the official statistics, females emigrated mainly as wives together with their husbands and families, while solitary emigrants were particularly found among males. Presumably, emigrants with leprosy particularly would be female patients, looked after by their male heads of the family. This is consistent with the peak of the female type-indexcurve in the decade 1891-1900, close to the culmination of the emigration wave in the southern region (Fig. 25).

\subsection{Prediction of incidence rates based on information on sex, age and type ${ }^{1}$}

Time trends in the distribution of leprosy according to sex, age and type of the disease, demonstrated to exist in the present material, formed the basis for analyses of possible associations between these characteristics of patients and incidence rates. The intention was in part to attempt to clarify general aspects of the epidemiology of the disease, in part to outline principles relevant to the construction of indices, useful in leprosy control. Such indices are still needed today because in most areas where leprosy is prevalent, accurate incidence rates may be impossible to obtain due to lack of vital statistics and incomplete registration of cases.

\subsubsection{LEVEL OF INCIDENCE RATES}

The associations between each of the independent variables, mean age at onset, sex ratio and type index (vide 2.5.3. and 2.5.5.) and incidence rate were studied by simple regression analyses. The correlation coefficients were -0.73 , -0.38 and 0.04 respectively (Table 28 ).

By the inclusion in a stepwise regression analysis of type index, in addition to mean age at onset, a multiple correlation coefficient of 0.74 was obtained (Table 28). By the inclusion of sex ratio, the multiple correlation coefficient did not increase. This regression function reduced significantly the total variance of the dependent variable $(p<0.001)$.

The regression line was:

$$
\hat{Y}=8.85-0.23 X_{1}+0.05 X_{2}+1.92 X_{3}
$$

( $X_{1}$ : mean age at onset, $X_{2}$ : sex ratio, $X_{3}$ : type index)

\footnotetext{
${ }^{1}$ Preliminary results reported by Bjerkedal and Irgens (1973) and Irgens et al. (1978).
} 
Table 28. Simple and multiple regression in 7 counties of incidence rate in a period on mean age at onset, sex ratio and type index of patients taken ill during the same period. (The National Leprosy Registry of Norway)

\begin{tabular}{llcc}
\hline \multicolumn{1}{c}{$\begin{array}{c}\text { Independent } \\
\text { variables }\end{array}$} & \multicolumn{1}{c}{$\begin{array}{c}\text { Regression } \\
\text { line }\end{array}$} & $\begin{array}{c}\text { Level of } \\
\text { significance }\end{array}$ & $\begin{array}{c}\text { Correlation } \\
\text { coefficient }\end{array}$ \\
\hline$X_{1}$ (Mean age at onset) & $Y=9.86-0.22 X_{1}$ & $\mathrm{p}<0.01$ & -0.73 \\
$X_{2}$ (Sex ratio) & $\hat{Y}=2.68-0.5 X_{2}$ & $\mathrm{p}=0.02$ & -0.38 \\
$X_{3}$ (Type index) & $\hat{Y}=8.53-0.22 X_{1}+2.16 X_{3}$ & $\mathrm{p}>0.05$ & 0.04 \\
$X_{1}, X_{3}$ & $\hat{Y}=8.85-0.23 X_{1}+0.05 X_{2}+1.92 X_{3}$ & $\mathrm{p}<0.01$ & 0.74 \\
$X_{1}, X_{2}, X_{3}$ & & & \\
\hline
\end{tabular}

Table 29. Simple and multiple regression in 7 counties of difference between incidence rates in two subsequent periods, on mean age at onset, sex ratio and type index of patients taken ill during the first of the two periods. (The National Leprosy Registry of Norway)

\begin{tabular}{lccc}
\hline \multicolumn{1}{c}{$\begin{array}{c}\text { Independent } \\
\text { variables }\end{array}$} & \multicolumn{1}{c}{$\begin{array}{c}\text { Regression } \\
\text { line }\end{array}$} & $\begin{array}{c}\text { Level of } \\
\text { significance }\end{array}$ & $\begin{array}{c}\text { Correlation } \\
\text { coefficient }\end{array}$ \\
\hline$X_{1}$ (Mean age at onset) & $\hat{Y}=3.84-0.09 X_{1}$ & $\mathrm{p}<0.01$ & -0.68 \\
$X_{2}$ (Sex ratio) & & $\mathrm{p}>0.05$ & -0.24 \\
$X_{3}$ (Type index) & $\hat{Y}=3.07-0.09 X_{1}+1.4 X_{3}$ & $\mathrm{p}>0.05$ & 0.01 \\
$X_{1}, X_{3}$ & $\hat{Y}=3.33-0.1 X_{1}+0.01 X_{2}+0.01 X_{3}$ & $\mathrm{p}<0.01$ & 0.70 \\
$X_{1}, X_{2}, X_{3}$ & & & 0.01 \\
\hline
\end{tabular}

Table 30. Evaluation of the prediction of level and time trend of incidence rates calculated on the basis of observations of mean age at onset, sex ratio and type index. (The National Leprosy Registry of Norway)

\begin{tabular}{|c|c|c|c|}
\hline \multirow[b]{3}{*}{ Predictions } & \multicolumn{3}{|c|}{ Observations } \\
\hline & \multirow{2}{*}{$\begin{array}{c}\text { Total } \\
\text { No. }\end{array}$} & \multicolumn{2}{|c|}{ Of these correctly classified } \\
\hline & & No. & $\%$ \\
\hline Prediction of level & 36 & 27 & $75 \cdot 0^{\dagger}$ \\
\hline Prediction of time trend & 30 & 23 & $76 \cdot 6^{+}$ \\
\hline
\end{tabular}

\subsubsection{TIME TREND IN INCIDENCE RATES}

The associations between each of the independent variables and time trend in incidence rate (vide 2.5.5.) were studied by simple regression analysis, and the correlation coefficients of mean age at onset, sex ratio and type index were $-0 \cdot 68,-0.24$ and 0.01 respectively (Table 29 ).

By the inclusion in a stepwise regression analysis of type index in addition to mean age at onset, a multiple correlation coefficient of 0.70 was obtained (Table 29). By the inclusion of sex ratio, the multiple correlation coefficient did not increase. Also this regression function reduced significantly the total variance of the dependent variable $(\mathrm{p}<0 \cdot 001)$. 
The regression line was:

$$
\hat{Y}=3.33-0 \cdot 1 X_{1}+0.01 X_{2}+0.01 X_{3}
$$

\subsubsection{EVALUATION}

The results of the evaluation of prediction of incidence level varied according to the cut-off point set to divide the observed incidence rates into high or low. At a cut-off point of $Y=4.5$, which represented the median of the observations, $75 \%$ of the observations were correctly classified on the basis of their predictions (Table 30).

Also in the prediction of time trends the results of the evaluation varied according to the cut-off point. At a cut-off point of $Y=4 \cdot 0$, also the median of the observations, $76.7 \%$ of the observations were correctly classified on the basis of their predictions.

According to a sign test, the results of the classifications differed significantly from a random distribution of the observations into two groups $(\mathrm{p}<0.005)$.

\subsubsection{COMMENTS}

The general epidemiological situation in Norway during the observation period was that of a rapid decline in incidence rates. Accordingly, this part of the study was focusing on how the characteristics of patients registered changed during such an observation period. The attempts to make valid predictions of level and trend in incidence rates were also restricted to this situation. However, not all observations were derived from a situation of rapid decline. Accordingly, to avoid a mixture of observations, in part from a situation of steady state, in part from a situation of rapid decline, only observations pertaining to the first decade in a county after which decrease in the incidence rate was observed and all subsequent decades, were used (vide 2.5.5.).

Since the data were registered during a long observation period, sex- and age-adjusted measures were used. Obviously, this is not possible when incidence rates are unknown. However, in a practical situation of leprosy control today, the need for adjustment will be smaller since data usually will relate to a short period of observation.

The distributions of the dependent variables were skewed, and since log transformation of these variables gave approximate normal curves, log transformed dependent variables were used in the analyses (vide 2.5.5.). The observations of the independent variables were evenly distributed along the $x$-axis, and results of analyses based on log transformation of one or more of the variables did not differ from results obtained using untransformed variables.

Evaluation of the predictions had to be based on data used in the calculation of the predictions. Preferably, evaluation should be based on a set of 
data pertaining to a situation to which one wants to generalize. However, application without adjustments in other areas, of the equations obtained in the present analyses, does not seem feasible. Areas in which leprosy is prevalent today, may differ considerably with respect to epidemiological conditions, such as sociological features, which may influence the equations.

Negative associations appeared to exist between mean age at onset and sex ratio on one hand and the dependent variables on the other. This was consistent with other findings in the present study and with findings by other authors (vide 4.2.3.). However, the low values of the correlation coefficient found in the analyses of the dependent variables on type index (regression coefficients not significant different from zero), were attributable to the selection of unit of observation; viz. counties in the high frequency areas. The range in type index was low (vide 3.2.3.), and the trend of a positive association between type index and incidence rates, found in other parts of this study (vide 3.6.1., 3.6.3.) did not appear at county level.

It should be stated that mean age at onset, sex ratio and type index represent rather rough epidemiological measures relinquishing valuable information, e.g., distribution of patients according to age at onset is much more informative than mean age at onset. Accordingly, even more useful predictions may be obtained on the basis of distributions of patients according to age, sex and type rather than the simple measures.

The results presented were based on knowledge of all patients taken ill. If, in field work, predictions are to be based only on a fraction of an unknown total patient group, as will be the case, this fraction should not differ significantly from the total patient group with respect to the independent variables. However, ascertainment of cases, or degree of completeness of reporting, usually is related to all these three independent variables, and, accordingly, adjustments will be needed.

\subsection{Isolation of patients and trends in subsequent incidence rates ${ }^{1}$}

Isolation of patients in special leprosy hospitals was in force in Norway from the middle of the last century; initially not to limit infection, but to attain sexual isolation and thereby limit further propagation of a disease presumed to be hereditary (Irgens, 1973). After the discovery of the leprosy bacillus in 1873, isolation was enforced even more consistently, however, now because leprosy was considered an infectious disease. Thus, degree of isolation in the 7 central leprosy counties (vide 2.5.5.) increased from $22.2 \%$ in the decade $1856-65$, to $55 \cdot 1 \%$ in the decade $1906-15$ (Fig. 30). As time went on, the Norwegian control programme, with its acts on segregation, became a prototype in an international perspective.

${ }^{1}$ Preliminary results reported by Irgens (1973a). 
Table 31. Simple linear regression in 7 counties $1856-1920$ of incidence rate in a period on previous prevalence rate. (The National Leprosy Registry of Norway)

\begin{tabular}{cccc}
\hline $\begin{array}{c}\text { Independent } \\
\text { variable }\end{array}$ & $\begin{array}{c}\text { Regression } \\
\text { line }\end{array}$ & $\begin{array}{c}\text { Level of } \\
\text { significance }\end{array}$ & $\begin{array}{c}\text { Correlation } \\
\text { coefficient }\end{array}$ \\
\hline Prevalence rates, total & $\hat{Y}=-0.15+0.19 X$ & $<0.01$ & 0.81 \\
Prevalence rates, district & $\hat{Y}=-0.54+0.33 X$ & $<0.01$ & 0.90 \\
\hline
\end{tabular}

However, the effectiveness of this segregation policy has been questioned ever since it was introduced, not only in Norway, but in most parts of the world. Today, when the infectiousness of most patients seems to be significantly reduced by regular chemotherapy (Meade, 1978; Skinsnes, 1975 among others) segregation represents no adequate control policy, mostly for humanitarian reasons. However, it may also be argued that isolation of an infectious person is without any effect, because isolation is first attained after the person has infected his environment. In an attempt to clarify these questions, which are closely related to important aspects of the epidemiology of leprosy, the possible effects of isolation of patients were studied.

\subsubsection{PREVALENCE RATES AND SUBSEQUENT INCIDENCE RATES}

If isolation, in an area, of infectious patients is to have an impact on subsequent incidence rates, incidence rates are to be considered the effect of previous prevalence rates. Accordingly, an association should exist between prevalence rates and subsequent incidence rates. In a simple regression analysis between these variables the regression line was:

$$
\hat{Y}^{\prime}=-0 \cdot 15+0 \cdot 19 X(\mathrm{p}<0 \cdot 01)
$$

with a correlation coefficient of $0 \cdot 81$ (Table 31 ).

Obviously, such an association will exist for a series of diseases, and, under given epidemiological conditions, even irrespective of the aetiology of the disease. However, an even higher coefficient was obtained using, as the independent variable, prevalence rates based on patient years spent in homes only, rather than total patient years. This finding was consistent with transmission of the disease from person to person and, accordingly, formed a rationale for isolation as a control measure. The regression line was:

$$
\hat{Y}=-0.54+0.33 X(\mathrm{p}<0.01)
$$

with a correlation coefficient of 0.90 (Table 31 ).

\subsubsection{ISOLATION AND SUBSEQUENT RELATIVE FALL IN INCIDENCE RATES}

In a simple regression analysis, based on all 7 counties, between degree of isolation registered in the 5 decades between 1856 and 1905, and subsequent relative fall in incidence rates, the regression line was 
Table 32. Simple linear regression in 7 counties 1856-1920 of relative fall in incidence rate in a period on previous degree of isolation. (The National Leprosy Registry of Norway)

\begin{tabular}{|c|c|c|c|}
\hline $\begin{array}{l}\text { Independent variable. } \\
\text { Groups of observations } \\
\text { by time and prevalence }\end{array}$ & $\begin{array}{l}\text { Regression } \\
\text { line }\end{array}$ & $\begin{array}{c}\text { Level of } \\
\text { significance }\end{array}$ & $\begin{array}{l}\text { Correlation } \\
\text { coefficient }\end{array}$ \\
\hline $\begin{array}{l}\text { Time: } 1856-1910 \\
\text { Prevalence: all levels }\end{array}$ & $\hat{Y}=7 \cdot 30+1 \cdot 28 X$ & $<0.01$ & $0 \cdot 80$ \\
\hline $\begin{array}{l}\text { Time: } 1856-1875 \\
\text { Prevalence: all levels }\end{array}$ & $\hat{Y}=1.02+1.45 X$ & $<0.01$ & $0 \cdot 77$ \\
\hline $\begin{array}{l}\text { Time: } 1881-1910 \\
\text { Prevalence: all levels }\end{array}$ & & $>0.05$ & $0 \cdot 16$ \\
\hline $\begin{array}{l}\text { Time: } 1856-1875 \\
\text { Prevalence: }>15 \cdot 0\end{array}$ & $\hat{Y}=-3.93+1.63 X$ & $<0.01$ & $0 \cdot 81$ \\
\hline $\begin{array}{l}\text { Time: } 1881-1910 \\
\text { Prevalence: } \leqq 15 \cdot 0\end{array}$ & & $>0.05$ & $0 \cdot 32$ \\
\hline $\begin{array}{l}\text { Time: } 1856-1875 \\
\text { Prevalence: }>29 \cdot 0\end{array}$ & $\hat{Y}=3 \cdot 41+1 \cdot 32 X$ & $0 \cdot 04$ & $0 \cdot 79$ \\
\hline $\begin{array}{l}\text { Time: } 1856-1875 \\
\text { Prevalence: } \leqq 29 \cdot 0\end{array}$ & $\hat{Y}=-4 \cdot 76+1 \cdot 76 X$ & 0.05 & $0 \cdot 75$ \\
\hline
\end{tabular}

$$
\hat{Y}=7 \cdot 30+1 \cdot 28 X(\mathrm{p}<0.01)
$$

with a correlation coefficient of $0 \cdot 80$ (Table 32).

Apparently, isolation led to an evident fall in incidence rates. However, in the evaluation of this association it should be taken into account that both the degree of isolation and the relative fall in incidence rates increased with time (Fig. 30). Accordingly, the association found to exist between these variables might be non-causal or secondary.

In an attempt to eliminate this effect of time on the association, the material was split into two groups; the first covering all counties during 2 decades of isolation, 1856-75, and the second covering all counties during 3 decades of isolation, 1881-1910.

In the first group of observations, covering the 2 decades $1856-75$, a strong positive association was found to persist between degree of isolation and subsequent relative fall in incidence rates; the regression line was:

$$
\hat{Y}=1.02+1.45 X(\mathrm{p}<0.01)
$$

with a correlation coefficient of 0.77 (Table 32 ).

However, in the last group of observations, covering the 3 decades 18811910 , no association between the variables was demonstrated; the correlation coefficient was $0 \cdot 16(p=0.49)$.

The decrease in the correlation coefficient with time might be associated with a decreasing prevalence experienced through the observation period from 1851 to 1920 . To find out whether the association between degree of isolation 


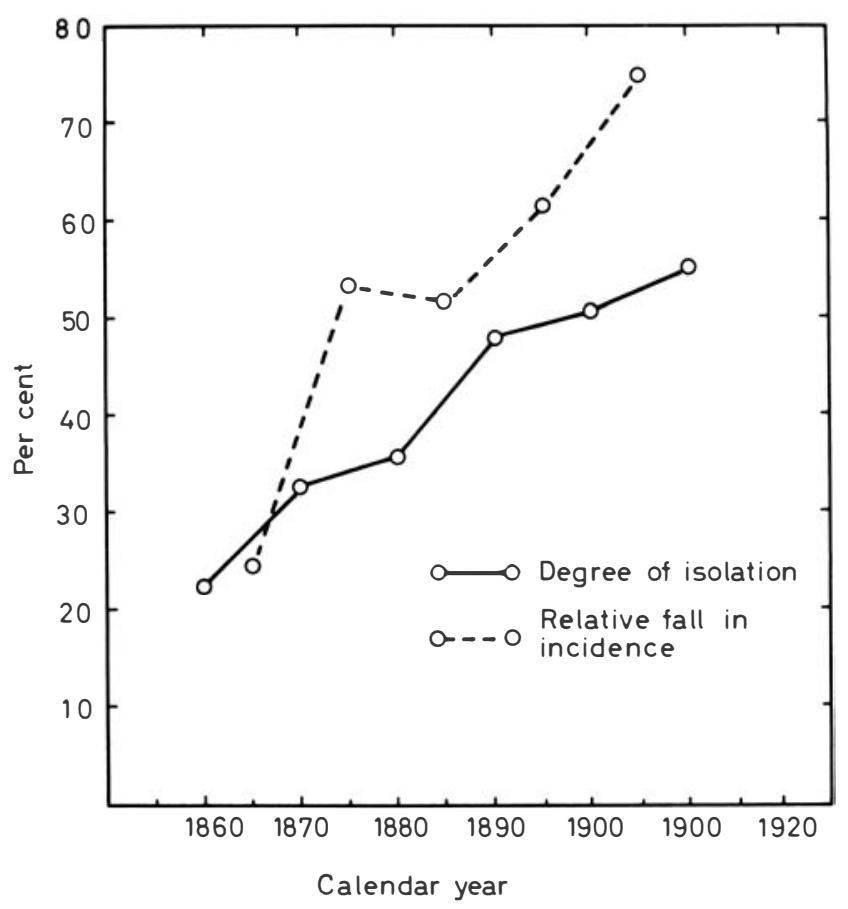

Figure 30. Degree of isolation of leprosy patients and relative fall in incidence of leprosy during the observation period. (The National Leprosy Registry of Norway.)

and relative fall in incidence rates was dependent on level of prevalence, and, at the same time, to eliminate the effect of time, the two groups of the material were split according to whether prevalence in period 1 was above or below 15 per 10,000 .

It appeared that in the first group of observations with low prevalence rates and in the last group with high prevalence rates, numbers of observations were too small for calculation of statistics. Still, in the remaining first group with high prevalence rates, the regression line was:

$$
\hat{Y}=-3.93+1.63 X(\mathrm{p}<0.01)
$$

with a correlation coefficient of 0.81 (Table 32).

Furthermore, the regression coefficient indicated a stronger association between the variables in the high prevalence initial group than in the total initial group.

On the other hand, in the remaining last group, with low prevalence rates, the correlation coefficient was $0.32(p=0.22)$.

However, the association between the variables did not appear to increase when the prevalence rates increased above 15 per 10,000. The first group of observations was divided according to whether prevalence rates were above or 
below the median of the group, 29 per 10,000. For the high prevalence observations the line was:

$$
\hat{Y}=3.41+1.32 X(\mathrm{p}=0.04)
$$

with a correlation coefficient of 0.79 (Table 32).

For the low prevalence observations the regression line was:

$$
\hat{Y}=-4.76+1.76 X(\mathrm{p}=0.05)
$$

with a correlation coefficient of 0.75 (Table 32).

\subsubsection{COMMENTS}

After observations were divided into two groups according to time, a strong association persisted in the first group between degree of isolation and relative fall in incidence. It should be noted that this group of observations covered only 2 decades of isolation compared with 3 decades in the last group. Yet, no association was found in the last group in which a factor associated with time, due to a longer span, might have been more efficient.

Furthermore, it appeared that the association between degree of isolation and relative fall in incidence was stronger when the level of prevalence was relatively high.

The organization of observations in consecutive double periods, each of 10 years' duration (vide 2.5.5.), represented a choice, justified in part by considerations with respect to length of incubation periods. Obviously, however, other combinations of periods for registration of possible causes and effects were possible. In fact, a series of such combinations were tried, changing systematically lengths and relative positions of the periods. It appeared that the combination of periods applied in the present study, justified by considering incubation periods, provided correlation and regression coefficients which indicated the strongest association between the variables. Besides, a far weaker association between degree of isolation and relative fall in incidence was found when fall in incidence was registered in a period prior to the period of registering degree of isolation. This finding also, seemed to indicate that the association found to exist between the variables was not secondary, viz. dependent on another factor associated with time.

Degree of isolation, calculated on the basis of type 1 (most infectious) patients only, might have been even stronger associated with relative fall in incidence rates. However, since there were indications that also type 3 patients were infectious (vide 4.2.4.) such an analysis was not attempted.

Nevertheless, it might be argued that the lack of association, observed in the low prevalence observations, towards the end of the observation period, was the result of a bias based on trends in the isolation policy; when degree of isolation was low, mostly type 1 patients were hospitalized, while when degree of isolation was high, a higher percentage of the isolated patients was not type 
Table 33. Families consisting of leprosy patients with type index, by number of patients per family. (The National Leprosy Registry of Norway)

\begin{tabular}{cccc}
\hline $\begin{array}{c}\text { Patients } \\
\text { per family }\end{array}$ & $\begin{array}{c}\text { Families } \\
\text { (No.) }\end{array}$ & $\begin{array}{c}\text { Patients } \\
\text { (No.) }\end{array}$ & $\begin{array}{c}\text { Type } \\
\text { index }\end{array}$ \\
\hline 1 & 5,710 & 5,710 & $60 \cdot 4$ \\
2 & 618 & 1,236 & $66 \cdot 3$ \\
3 & 203 & 609 & $71 \cdot 0$ \\
4 & 79 & 316 & $67 \cdot 8$ \\
$5+$ & 28 & 156 & $75 \cdot 8$ \\
\hline Total & 6,638 & 8,027 & $62 \cdot 7$ \\
\hline
\end{tabular}

1 patients. Accordingly, degree of isolation towards the end of the period, in terms of percentage of isolated infectious patients, would have been lower than indicated in the results presented. Thus, relative fall in incidence rates would have been expected to be lower towards the end of the observation period. However, the opposite trend was found (Fig. 30).

\subsection{Leprosy in families}

In Norway, as in most countries where leprosy is prevalent today, the disease was known to affect certain families more than others (Danielssen and Boeck, 1847; Sand, 1910; Lie, 1911). This fact has led several authors to the conclusion that genetic factors play a part in the aetiology of leprosy (Spickett, 1962a and 1962b; Chakravartti and Vogel, 1973; Mohammed Ali, 1965). Obviously, for relatives, often living closely together, separation of genetic factors from environmental factors represents a serious methodological problem. However, due to sociological patterns, groups of people presumably with a common genetic background may differ with respect to environmental factors. In an attempt to isolate environmental factors from a joint genetic background, and vice versa, the information of the Leprosy Registry on kinship between patients was used to study factors responsible for the development of the disease into different types.

\subsubsection{ALL PATIENTS MUTUALLY RELATED}

Of 8,027 patients with known type of leprosy, as many as 2,317 (28.9\%) were registered as mutually related in some way (Table 33). In addition, unspecified information on non-identified 'leprous relatives' was registered for a considerable number of patients.

Type index increased with increasing number of patients in the family, from 60.4 in 5,710 patients without any affected relatives to 75.8 in 156 patients representing families with 5 or more patients (Table 33). 
Table 34. Sibship groups consisting of leprosy patients with type index, by age at onset and number of patients per group. (The National Leprosy Registry of Norway)

\begin{tabular}{|c|c|c|c|c|c|c|c|c|c|}
\hline \multirow{3}{*}{$\begin{array}{l}\text { Patients } \\
\text { per } \\
\text { sibship } \\
\text { group }\end{array}$} & \multirow[b]{3}{*}{ Groups } & \multicolumn{2}{|l|}{ Total } & \multicolumn{6}{|c|}{ Age at onset } \\
\hline & & \multirow[b]{2}{*}{ Patients } & \multirow[b]{2}{*}{$\begin{array}{l}\text { Type } \\
\text { index }\end{array}$} & \multicolumn{3}{|c|}{$\begin{array}{l}\text { All patients in the } \\
\text { sibship }<30 \text { years }\end{array}$} & \multicolumn{3}{|c|}{$\begin{array}{l}\text { One or more patients in } \\
\text { the sibship } \geqq 30 \text { years }\end{array}$} \\
\hline & & & & Groups & Patients & $\begin{array}{l}\text { Type } \\
\text { index }\end{array}$ & Groups & Patients & $\begin{array}{l}\text { Type } \\
\text { index }\end{array}$ \\
\hline 2 & 399 & 798 & $67 \cdot 6$ & 227 & 454 & 64.9 & 172 & 344 & $71 \cdot 2$ \\
\hline 3 & 89 & 267 & $70 \cdot 6$ & 51 & 153 & $78 \cdot 2$ & 38 & 114 & $60 \cdot 2$ \\
\hline $4+$ & 28 & 121 & $77 \cdot 6$ & 17 & 77 & $80 \cdot 3$ & 11 & 44 & $72 \cdot 2$ \\
\hline Mean & \multicolumn{3}{|c|}{$2 \cdot 30$} & \multicolumn{3}{|c|}{$2 \cdot 32$} & \multicolumn{3}{|c|}{$2 \cdot 27$} \\
\hline Total & 516 & 1,186 & $69 \cdot 4$ & 295 & 684 & 69.9 & 221 & 502 & $68 \cdot 7$ \\
\hline
\end{tabular}

The distribution of cases by type within each of these families differed significantly from the expected distribution calculated on the basis of relative frequencies of the three types in each group, demonstrating that special subgroups of families were more frequent than expected (vide 2.5.5.). The patients in these families tended to be more concordant with respect to type of the disease than expected. Mean distance between patients in a family was $0 \cdot 76$, while expected distance was $0 \cdot 87$; i.e. families with concordant cases were more frequent and families with disconcordant cases less frequent than expected. For instance, in the group with 2 patients per family, 213 families with two type 1 cases were observed against 183.8 expected families, and 68 families with two type 3 cases were observed against 47.6 expected families. On the other hand, only 149 families with one type 1 case and one type 3 case were observed against $187 \cdot 0$ expected families.

\subsubsection{SIBSHIPS}

Of the 2,317 patients mutually related, $1,186(51 \cdot 2 \%)$ belonged to a sibship of two or more patients (Table 34).

The trend of an increasing type index with an increasing number of patients per family was evident also in sibship groups. Type index increased from $67 \cdot 6$ in 798 patients representing families consisting of 2 affected siblings to 77.6 in 121 patients representing families consisting of 4 or more affected siblings (Table 34).

This trend was particularly expressed in the 295 sibships in which all patients were taken ill before the age of 30 (Table 34). No such trend was found in the other 221 sibships. Apparently, the association demonstrated between type index and number of patients per family was dependent on age at onset. Type index for the totals in both groups was almost the same, 69.9 and 68.7 , and so was mean number of patients per sibship: 2.32 and 2.27 respectively (Table 34 ). 
Table 35. Patient groups consisting of parents and their children, with type index. (The National Leprosy Registry of Norway)

\begin{tabular}{|c|c|c|c|c|c|c|c|c|c|c|}
\hline \multirow[b]{3}{*}{$\begin{array}{l}\text { Parent } \\
\text { affected }\end{array}$} & \multicolumn{5}{|c|}{ Total } & \multicolumn{5}{|c|}{$\begin{array}{l}\text { Of these: } \\
\text { One or both parents with type } 1\end{array}$} \\
\hline & \multicolumn{2}{|c|}{ Parents } & \multicolumn{2}{|c|}{ Children } & \multirow{2}{*}{$\begin{array}{l}\text { Children } \\
\text { per } \\
\text { marriage }\end{array}$} & \multicolumn{2}{|c|}{ Parents } & \multicolumn{2}{|c|}{ Children } & \multirow{2}{*}{$\begin{array}{l}\text { Children } \\
\text { per } \\
\text { marriage }\end{array}$} \\
\hline & No. & $\begin{array}{l}\text { Type } \\
\text { index }\end{array}$ & No. & $\begin{array}{l}\text { Type } \\
\text { index }\end{array}$ & & No. & $\begin{array}{l}\text { Type } \\
\text { index }\end{array}$ & No. & $\begin{array}{l}\text { Type } \\
\text { index }\end{array}$ & \\
\hline $\begin{array}{l}\text { Fathers } \\
\text { affected } \\
\text { Mothers }\end{array}$ & 199 & $66 \cdot 4$ & 270 & $65 \cdot 9$ & $1 \cdot 36$ & 99 & $100 \cdot 0$ & 137 & $76 \cdot 3$ & $1 \cdot 38$ \\
\hline $\begin{array}{l}\text { affected } \\
\text { Both } \\
\text { parents } \\
\text { affected }\end{array}$ & 161 & $67 \cdot 4$ & 264 & $77 \cdot 2$ & $1 \cdot 64$ & 87 & $100 \cdot 0$ & 151 & $78 \cdot 6$ & $1 \cdot 74$ \\
\hline Total & 400 & $65 \cdot 4$ & 560 & $71 \cdot 5$ & 1.47 & 216 & $95 \cdot 3$ & 309 & $76 \cdot 8$ & $1 \cdot 54$ \\
\hline
\end{tabular}

Also in this category, the distribution of cases by type within each of the families differed significantly from the expected distribution, and the patients were also more concordant with respect to type than expected. However, within families in which age at onset was 30 years or more, the distribution did not differ significantly from the expected distribution.

\subsubsection{PARENTS AND CHILDREN}

A total of 400 affected parents in 380 marriages had 560 affected children; 1.47 children per marriage (Table 35). Type index in these children was 71.5. In 216 marriages in which one or both parents were affected with type 1 , type index of the 309 children was 76.8 and children per marriage was $1 \cdot 54$.

A total of 199 affected fathers had 270 affected children, on average 1.36 children per parent; while 161 affected mothers had 264 affected children, on average 1.64 children per parent (Table 35). Type index in children of fathers (65.9) was lower than type index in children of mothers (77.2) despite the fact that the type index of the fathers (66.4) was not far from the type index of the mothers (67.4).

Considering parents affected with type 1, type index in children of fathers (76.3) was almost equal to type index in children of mothers (78.6). However, the difference mentioned with respect to number of children per parent was even greater for parents affected with type 1; on average a father had 1.38 affected children while a mother had 1.74 children.

A total of 26 children had parents both of whom were affected with leprosy. Type index in these children was 73.9.

Type index in children of affected mothers increased with an increasing 
Table 36. Spouses who both were affected by leprosy, with type index, mean age at onset and number of males per 100 females. (The National Leprosy Registry of Norway)

\begin{tabular}{ccccc}
\hline Class of spouses & Spouses & $\begin{array}{c}\text { Type } \\
\text { index }\end{array}$ & $\begin{array}{c}\text { Mean age } \\
\text { at onset }\end{array}$ & $\begin{array}{c}\text { Males per } \\
\text { 100 females }\end{array}$ \\
\hline First cases & 34 & $46 \cdot 2$ & $43 \cdot 9$ & $88 \cdot 8$ \\
Second cases & 34 & $63 \cdot 3$ & $50 \cdot 8$ & $112 \cdot 5$ \\
Second cases $^{\dagger}$ & 24 & $60 \cdot 0$ & $45 \cdot 2$ & $60 \cdot 0$ \\
Contemporary cases $^{\text {Total }}$ & 26 & $80 \cdot 8$ & $48 \cdot 8$ & $100 \cdot 0$ \\
\hline
\end{tabular}

† First case not registered

number of children per mother from 73.2 for 1 child to 81.7 for 3 or more children. Such a trend was not found in children of affected fathers.

The distribution of children by type of disease and by type of their parent's disease differed significantly from the expected distribution both for children of affected fathers $(p=0.004)$ and for children of affected mothers $(p=0.02)$. It was evident that concordance between parents and children with respect to type of the disease was more frequent than expected; e.g. fathers with type 1 had 97 children with type 1 against 85.0 expected and 30 children with type 3 against $42 \cdot 5$ expected.

Consistent with the finding of a more significant dependence between fathers and children than between mothers and children, significant dependence was found within sibships of patients with sick fathers. Within sibships of patients with a sick mother, however, the distribution of cases by type in each of the families did not differ significantly from what was expected; i.e. the observed frequencies of the different subgroups did not differ significantly from the expected frequencies.

\subsubsection{MARRIAGES}

Total number of marriages in which only one spouse was affected, is unknown. However, 380 marriages were registered in which one spouse and one or more children were affected. In 20 of these marriages the other spouse also became affected. Accordingly, secondary attack rate among spouses in marriages in which the other spouse and one or more children were affected was 5.3\%.

Information was registered on a total of 71 marriages in which both spouses were affected. Of the total of 142 spouses, 24 were not registered as patients; apparently because they died before compulsory notification was effected (Table 36). Type index of the remaining 118 spouses registered was 62.7 (Table 36).

According to onset of disease in the marriages, the spouses were considered as belonging to one of four different classes (Table 36). Onset was regarded contemporary (i.e. difference between years of onset in two spouses less than 3 years) for 26 spouses, whose type index was $80 \cdot 8$. In the marriages without 
contemporary onset, type index of the first cases was $46 \cdot 2$, while type index of the second cases was $63 \cdot 3$. Type index of the spouses whose affected spouse was not registered, mostly second cases, was $60 \cdot 0$.

Number of males per 100 females was 88.8 among the first cases and 112.5 among the second cases. Mean age at onset was 43.9 years in the first cases, 50.8 years in the second cases and 48.8 years in the spouses with contemporary onset of the disease.

In the whole category of spouses as well as in the different classes, the distribution of cases by type did not differ from what was expected.

\subsubsection{COMMENTS}

Most likely, information on an unknown number of mutual relationships between patients registered in the Leprosy Registry is lacking. Furthermore, information on relationships between patients registered and patients who died before registration was initiated, is most incomplete. Still, the information used in the present study, focusing on trends in intrafamilial distributions of the type of disease rather than intrafamilial rates, is considered satisfactory.

The trends demonstrated are probably not influenced by a biased registration. The possibility exists, for instance, that many sibships, consisting of only two patients were overlooked; however, this should have occurred most often in cases never admitted to hospital, i.e. particularly in type 3 cases. In the hospital register as well as in the hospital patient records, detailed information on affected relatives is at hand. Accordingly, such a bias would mask rather than produce a trend that indicated an increase in type index by number of patients per family.

A bias in registration, influencing concordance with respect to type index in one or the other way, seems unlikely.

In the calculation of secondary attack rate among spouses it was not possible to state whether the second case taken ill was infected by the first case. This problem is always encountered in the calculation of secondary attack rates. However, if it is true that duration of exposure plays a part in the aetiology of leprosy, it may be difficult to identify a single source of infection, and the practical importance of the problem might be low.

\subsection{Leprosy in a high frequency district}

A considerable variation in the geographical distribution of the disease, demonstrated in the whole country as well as in the high frequency areas, was also found to exist between the health districts in the county with the highest average incidence rate, Sogn \& Fjordane. However, even in the health district with the highest average incidence rate in the country, Naustdal, the frequency of the disease varied considerably from village to village and from farm to farm. 


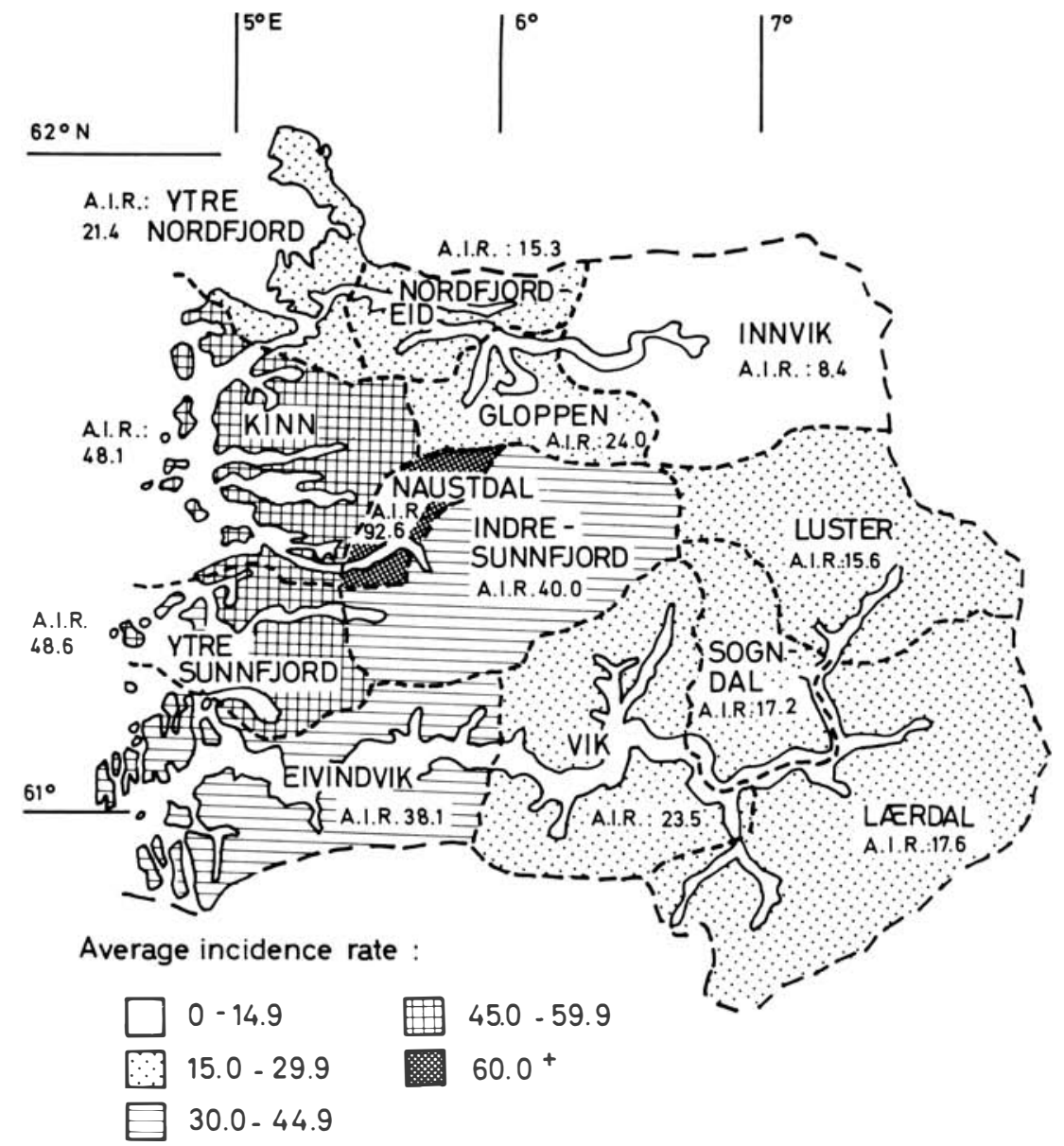

Figure 31. Average incidence rates (A.I.R.) of leprosy in Norway, 1851-1920, in the health districts of Sogn \& Fjordane. (The National Leprosy Registry of Norway.)

In an attempt to characterize conditions in localities where the disease was particularly frequent compared with localities without leprosy, the occurrence of the disease in Naustdal was studied in detail.

Viewed by contemporary physicians, living conditions in the western regions of South Norway, and particularly in Naustdal, were bad in the middle of the last century (Bidenkap, 1858; 1860; Hjort, 1871). The intention of this part of the study was to study possible associations between leprosy and environmental factors like overcrowding, malnutrition and poverty. Furthermore, the geographical distribution of cases was envisaged in an attempt to test a hypothesis suggesting sphagnum bog vegetation as a possible reservoir of non cultivable mycobacteria (Kazda et al., 1979, Kazda 1979) which may be associated with disease in man. 


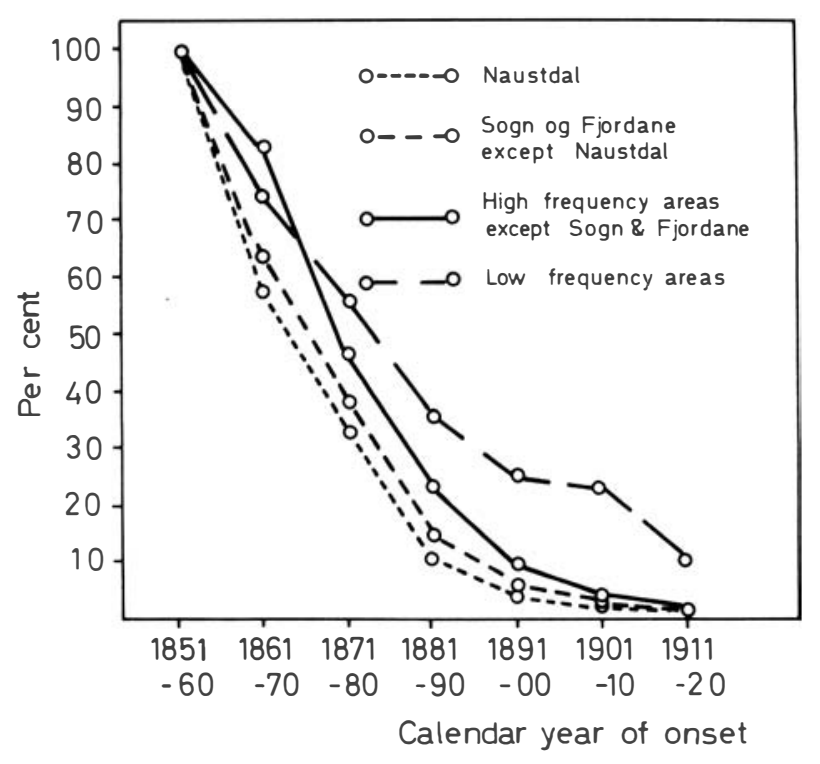

Figure 32. Incidence rates of leprosy in Norway, 1851-1920, by residential district. Crude rates by year of onset, 1851-60 =100. (The National Leprosy Registry of Norway.)

\subsubsection{DISTRICT LEVEL}

From an evident maximum of 92.6 in Naustdal, average incidence rates in the health districts of Sogn \& Fjordane decreased in all directions, the highest rates being confined to the coastal health districts near Naustdal (Fig. 31).

Annual incidence rates declined more rapidly in Naustdal through the observation period than in many other districts. Of the 171 patients with year of onset after 1850, the last patient was taken ill in 1903. Relative fall in incidence was slower in the rest of the high frequency areas. The slowest decrease of the disease was found in the low frequency areas (Table 37, Fig. 32).

Average age-specific incidence rates in the different areas demonstrated that the younger age groups of patients were relatively more frequent in areas with high incidence rates (Table 38, Fig. 33). Relative frequency of patients taken ill at an age of 50 years or more was particularly high in the low frequency areas. Thus, mean age at onset for patients taken ill during the observation period was particularly low, 31.0 , in Naustdal and increased through the areas mentioned above to $39 \cdot 3$ in the low frequency areas (Table 38). 
Table 37. New cases of leprosy by residential district in Norway, 1851-1920, according to year of onset with annual incidence rates in consecutive decades and average incidence rates in the observation period, per 100,000. (The National Leprosy Registry of Norway)

\begin{tabular}{|c|c|c|c|c|c|c|c|c|c|c|}
\hline \multirow[b]{2}{*}{$\begin{array}{c}\text { Year of } \\
\text { onset }\end{array}$} & \multicolumn{2}{|c|}{$\begin{array}{l}\text { Total } \\
\text { country }\end{array}$} & \multicolumn{2}{|c|}{ Naustdal } & \multicolumn{2}{|c|}{$\begin{array}{l}\text { Sogn \& Fjordane } \\
\text { except Naustdal }\end{array}$} & \multicolumn{2}{|c|}{$\begin{array}{l}\text { High frequency areas } \\
\text { except Sogn \& Fjord. }\end{array}$} & \multicolumn{2}{|c|}{$\begin{array}{l}\text { Low frequency } \\
\text { areas }\end{array}$} \\
\hline & $\begin{array}{l}\text { Patients } \\
\text { No. }\end{array}$ & Incidence & $\begin{array}{l}\text { Patients } \\
\text { No. }\end{array}$ & Incidence & $\begin{array}{l}\text { Patients } \\
\text { No. }\end{array}$ & Incidence & $\begin{array}{l}\text { Patients } \\
\text { No. }\end{array}$ & Incidence & $\begin{array}{l}\text { Patients } \\
\text { No. }\end{array}$ & Incidence \\
\hline $1851-1860$ & 2,355 & $15 \cdot 8$ & 84 & $318 \cdot 3$ & 667 & $84 \cdot 6$ & 1,567 & $25 \cdot 6$ & 37 & 0.47 \\
\hline $1861-1870$ & 2,005 & $11 \cdot 8$ & 48 & $181 \cdot 9$ & 447 & $53 \cdot 1$ & 1,478 & $21 \cdot 2$ & 32 & $0 \cdot 35$ \\
\hline $1871-1880$ & 1,241 & $6 \cdot 8$ & 27 & $102 \cdot 3$ & 265 & $31 \cdot 7$ & 924 & $12 \cdot 0$ & 25 & $0 \cdot 26$ \\
\hline $1881-1890$ & 615 & $3 \cdot 2$ & 9 & $34 \cdot 1$ & 100 & $11 \cdot 9$ & 489 & 5.9 & 17 & $0 \cdot 17$ \\
\hline $1891-1900$ & 276 & $1 \cdot 3$ & 2 & $7 \cdot 5$ & 41 & $4 \cdot 8$ & 220 & $2 \cdot 5$ & 13 & $0 \cdot 12$ \\
\hline $1901-1910$ & 117 & 0.51 & 1 & $3 \cdot 8$ & 19 & $2 \cdot 2$ & 84 & $0 \cdot 85$ & 13 & $0 \cdot 11$ \\
\hline $1911-1920$ & 43 & $0 \cdot 17$ & 0 & - & 4 & 0.46 & 33 & $0 \cdot 30$ & 6 & 0.05 \\
\hline $1851-1920$ & 6,652 & $4 \cdot 8^{\dagger}$ & 171 & $92 \cdot 6$ & 1,543 & $26 \cdot 1^{\dagger}$ & 4,795 & $8 \cdot 1^{\dagger}$ & 143 & $0 \cdot 19$ \\
\hline
\end{tabular}

† Average incidence rates 
Table 38. Average age-specific incidence rates with mean age at onset, sex ratio and type index of leprosy by residential district in Norway, 1851-1920. (The National Leprosy Registry of Norway)

\begin{tabular}{|c|c|c|c|c|c|c|c|}
\hline \multirow{2}{*}{$\begin{array}{c}\text { Residential } \\
\text { district }\end{array}$} & \multicolumn{4}{|c|}{ Age-specific incidence rates } & \multirow{2}{*}{$\begin{array}{l}\text { Mean age } \\
\text { at onset }\end{array}$} & \multirow{2}{*}{$\begin{array}{l}\text { Sex } \\
\text { ratio }\end{array}$} & \multirow{2}{*}{$\begin{array}{l}\text { Type } \\
\text { index }\end{array}$} \\
\hline & $0-14$ yrs & $15-29$ yrs & $30-49$ yrs & $50+y r s$ & & & \\
\hline $\begin{array}{l}\text { Naustdal } \\
\text { Sogn \& } \\
\text { Fjordane } \\
\text { except }\end{array}$ & $39 \cdot 3$ & $156 \cdot 6$ & $119 \cdot 2$ & $63 \cdot 2$ & $31 \cdot 0$ & $108 \cdot 7$ & $73 \cdot 6$ \\
\hline $\begin{array}{l}\text { Naustdal } \\
\text { High frequency } \\
\text { areas except } \\
\text { Sogn \& }\end{array}$ & $11 \cdot 1$ & $45 \cdot 2$ & $36 \cdot 4$ & $19 \cdot 2$ & $31 \cdot 5$ & $126 \cdot 4$ & $63 \cdot 8$ \\
\hline $\begin{array}{c}\text { Fjordane } \\
\text { Low frequency }\end{array}$ & $2 \cdot 65$ & $12 \cdot 2$ & $12 \cdot 6$ & $8 \cdot 04$ & $34 \cdot 5$ & $160 \cdot 3$ & $64 \cdot 9$ \\
\hline areas & $0 \cdot 05$ & $0 \cdot 22$ & $0 \cdot 29$ & $0 \cdot 31$ & $39 \cdot 3$ & $145 \cdot 1$ & $45 \cdot 5$ \\
\hline
\end{tabular}

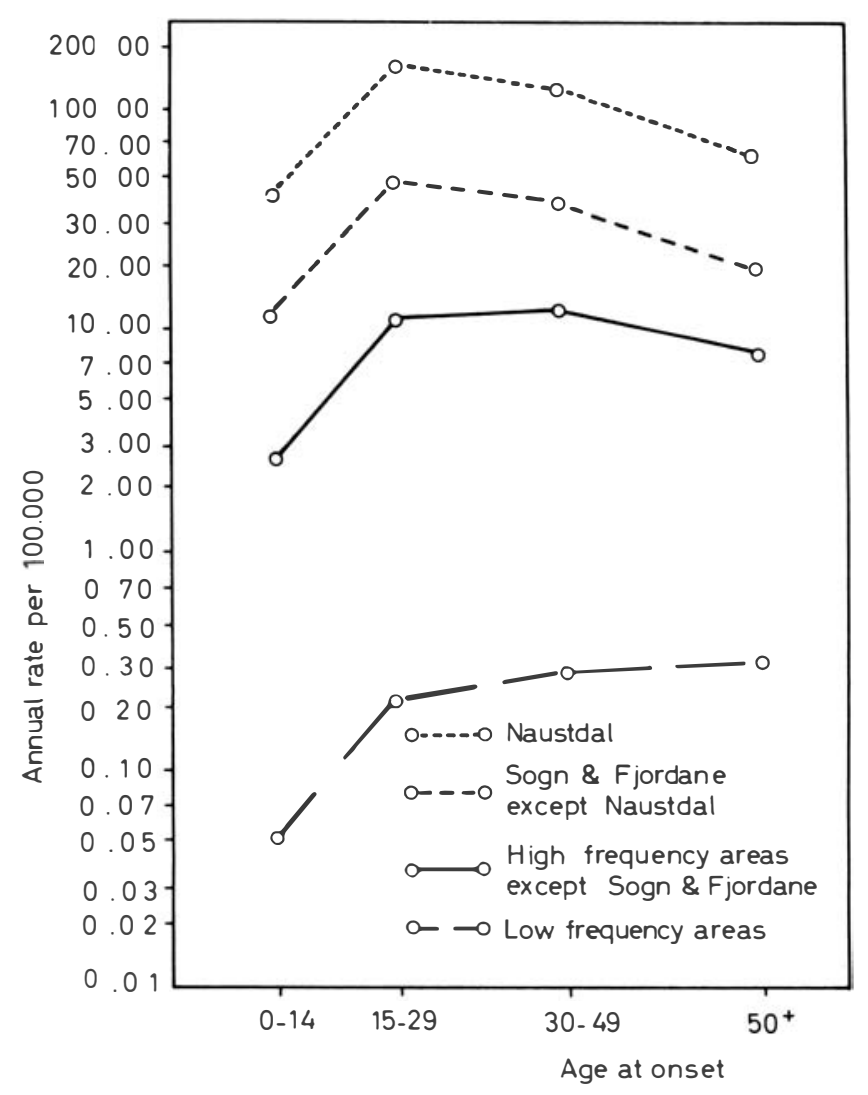

Figure 33. Incidence rates of leprosy in Norway, 1851-1920, by residential district. Agespecific average incidence rates. (The National Leprosy Registry of Norway.) 


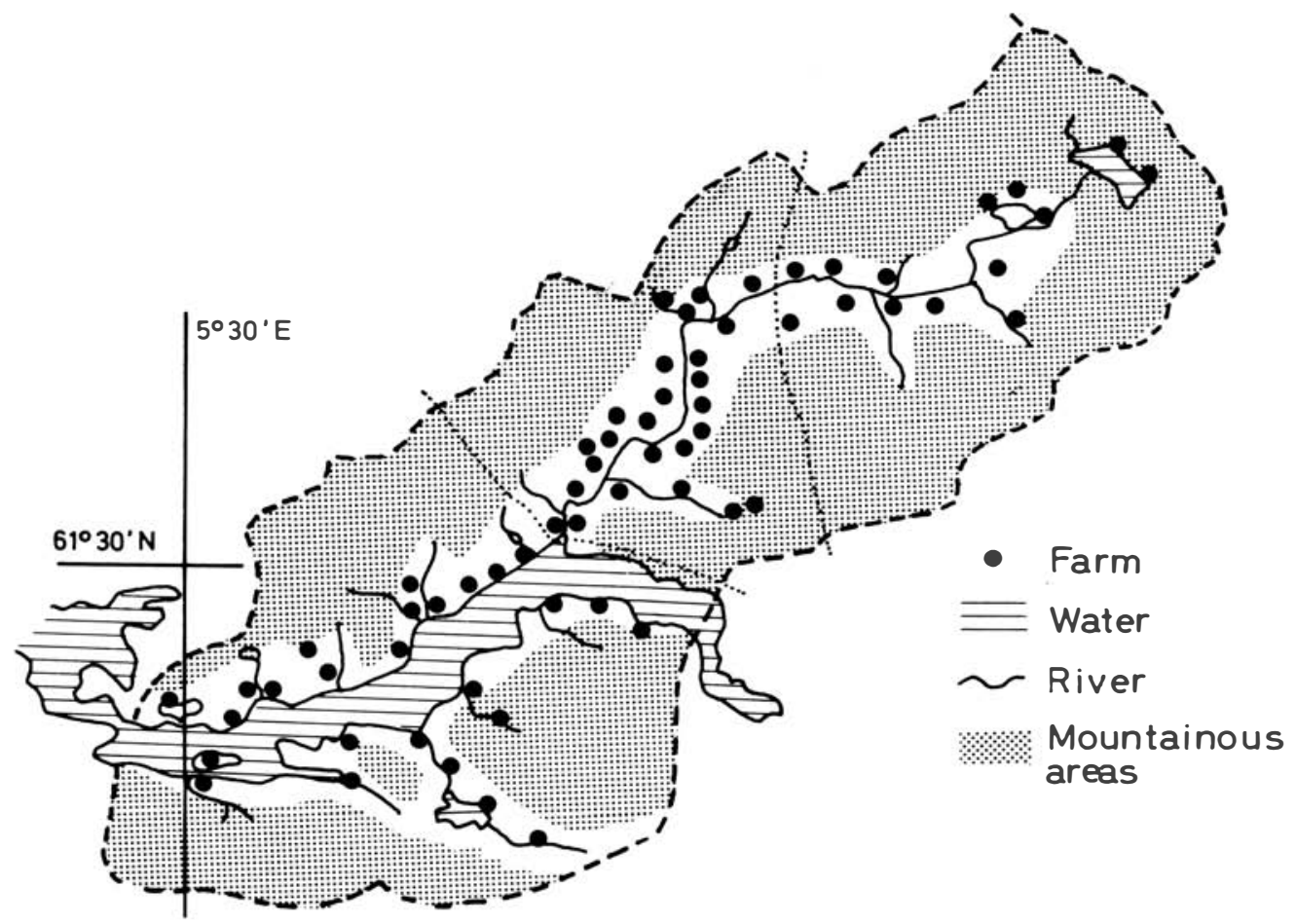

Figure 34. Health district of Naustdal.

Sex ratio, based on average sex-specific incidence rates, was close to 100 in Naustdal. Sex ratio appeared to increase with decreasing incidence rates, to 126.4 in Sogn \& Fjordane except Naustdal and to $160 \cdot 3$ in the high frequency areas except Sogn \& Fjordane. In the low frequency areas sex ratio was $145 \cdot 1$ (Table 38).

For type index, calculated on the basis of all patients taken ill during the observation period, the highest value was found in Naustdal, with 73.6. Type index decreased through the same areas and the lowest value, $45 \cdot 5$, was found in the low frequency areas (Table 38).

For the measures mean age at onset, sex ratio and type index no evident time trend was demonstrated in Naustdal.

\subsubsection{COUNTRYSIDE LEVEL}

On the basis of communications and topography, Naustdal was divided into 4 parts: the southern and northern banks of the fjord, and the lower and upper parts of the valley (Fig. 34). Total number of patients registered in these areas per 1,000 inhabitants present in 1865 were $49 \cdot 6,87 \cdot 0,72 \cdot 5$ and $76 \cdot 4$ respectively, indicating a difference between the two banks of the fjord with a higher rate on the northern bank. 
Table 39. Number of farms and patients living at the farms with mean age at onset, ${ }^{\dagger}$ sex ratio $^{\dagger}$ and type index of leprosy in Naustdal, Norway, 1851-1920, by total farm rate. (The National Leprosy Registry of Norway)

\begin{tabular}{cccccc}
\hline Total farm rate & Farms & Patients & $\begin{array}{c}\text { Mean age } \\
\text { at onset }\end{array}$ & $\begin{array}{c}\text { Males per } \\
100 \text { females }\end{array}$ & $\begin{array}{c}\text { Type } \\
\text { index }\end{array}$ \\
\hline 0 & 29 & 0 & - & - & - \\
$0 \cdot 1-59 \cdot 9$ & 15 & 29 & $31 \cdot 2$ & $70 \cdot 6$ & $60 \cdot 8$ \\
$60 \cdot 0-119 \cdot 9$ & 25 & 86 & $32 \cdot 1$ & $95 \cdot 5$ & $70 \cdot 4$ \\
$\geqslant 120 \cdot 0$ & 15 & 77 & $26 \cdot 7$ & $108 \cdot 1$ & $79 \cdot 4$ \\
\hline
\end{tabular}

tThe measures are based on crude number of patients

\subsubsection{FARM LEVEL}

Even at farm level the occurrence of the disease varied considerably. At 29 out of a total of 84 farms in Naustdal, no case was registered, while 192 cases were registered at the remaining 55 farms. Total farm rate (vide 2.5.3.) of these farms ranged between 10.7 and 428.6 . In 3 cases information necessary for allocating the patient to a farm was lacking.

The farms were grouped according to total farm rate (Table 39). At farms where total farm rate exceeded $120 \cdot 0$, mean age at onset was particularly low, 26.7 years, compared with the farms where total farm rate was lower. For number of males per 100 females no significant trend was demonstrated. Type index at the high rate farms was particularly high, $79 \cdot 4$, and a gradual decrease was found at farms with lower total farm rates. This was consistent with the finding of a median total farm rate of 81.9 at farms where type index was below 70 , while at the remaining farms, median total farm rate amounted to $110 \cdot 1$.

\section{Distance from the sea}

The difference in incidence rates already demonstrated, between inland and coastal districts (vide 3.1.1.), called to a similar analysis on farm level. All farms except one were grouped according to whether distance from the farm to the sea was below or above $0.5 \mathrm{~km}$. (Due to the large area of the farm, one farm could not be grouped according to this criterion.) First of all fishing, but also shipping were considered far more common trades at farms closer to the sea than $0.5 \mathrm{~km}$.

Of 63 farms, with a distance from the sea of more than $0.5 \mathrm{~km}, 40(63.5 \%)$ were leprosy positive farms. Median total farm rate was 62.7 (Table 40). Of 20 farms, with a distance from the sea of $0.5 \mathrm{~km}$ or less, $14(70.0 \%)$ were leprosy positive farms, and median total farm rate was $51 \cdot 3$. No association was demonstrated between distance from the farm to the sea and leprosy status of the farm, $\mathrm{p}=0.59$. 
Table 40. Farms in Naustdal, Norway, by leprosy status with median total farm rate, according to whether distance to the sea was below or above $0.5 \mathrm{~km}$. (The National Leprosy Registry of Norway)

\begin{tabular}{|c|c|c|c|c|}
\hline \multirow{2}{*}{$\begin{array}{l}\text { Distance } \\
\text { from the } \\
\text { sea } \\
(\mathrm{km})\end{array}$} & \multirow[b]{2}{*}{$\begin{array}{c}\text { Total } \\
\text { (No.) } \\
(\%)\end{array}$} & \multicolumn{2}{|c|}{ Leprosy status } & \multirow{2}{*}{$\begin{array}{c}\text { Total } \\
\text { farm } \\
\text { rate } \\
\text { (median) }\end{array}$} \\
\hline & & $\begin{array}{l}\text { L. positive } \\
\text { (No.) } \\
(\%)\end{array}$ & $\begin{array}{l}\text { L. negative } \\
\text { (No.) } \\
(\%)\end{array}$ & \\
\hline $0-0 \cdot 50$ & 20 & 14 & 6 & $51 \cdot 3$ \\
\hline$\geqslant 0.51$ & $\begin{array}{c}100 \cdot 0 \\
63 \\
100 \cdot 0\end{array}$ & $\begin{array}{l}70 \cdot 0 \\
40 \\
63 \cdot 5\end{array}$ & $\begin{array}{l}30 \cdot 0 \\
23 \\
36 \cdot 5\end{array}$ & $62 \cdot 7$ \\
\hline Total & $\begin{array}{c}83 \\
100 \cdot 0\end{array}$ & $\begin{array}{l}54 \\
65 \cdot 1\end{array}$ & $\begin{array}{l}29 \\
34 \cdot 9\end{array}$ & $55 \cdot 0$ \\
\hline
\end{tabular}

$\mathrm{p}=0.59$

Table 41. Farms in Naustdal, Norway, by leprosy status with median total farm rate, according to whether production of oats per person was below or above the median. (The National Leprosy Registry of Norway)

\begin{tabular}{|c|c|c|c|c|}
\hline \multirow[b]{2}{*}{$\begin{array}{c}\text { Production } \\
\text { of oats } \\
\text { per person }\end{array}$} & \multirow[b]{2}{*}{$\begin{array}{l}\text { Total } \\
\text { (No.) } \\
(\%)\end{array}$} & \multicolumn{2}{|c|}{ Leprosy status } & \multirow{2}{*}{$\begin{array}{c}\text { Total } \\
\text { farm } \\
\text { rate } \\
\text { (median) }\end{array}$} \\
\hline & & $\begin{array}{l}\text { L. positive } \\
\text { (No.) } \\
\text { (\%) }\end{array}$ & $\begin{array}{l}\text { L. negative } \\
\text { (No.) } \\
(\%)\end{array}$ & \\
\hline Below median & $\begin{array}{c}42 \\
100 \cdot 0\end{array}$ & $\begin{array}{l}31 \\
73 \cdot 8\end{array}$ & $\begin{array}{l}11 \\
26 \cdot 2\end{array}$ & $53 \cdot 0$ \\
\hline Above median & $\begin{array}{c}42 \\
100 \cdot 0\end{array}$ & $\begin{array}{l}24 \\
57 \cdot 1\end{array}$ & $\begin{array}{l}18 \\
42 \cdot 9\end{array}$ & $58 \cdot 0$ \\
\hline Total & $\begin{array}{c}84 \\
100 \cdot 0\end{array}$ & $\begin{array}{l}55 \\
65 \cdot 5\end{array}$ & $\begin{array}{l}29 \\
34 \cdot 5\end{array}$ & $55 \cdot 0$ \\
\hline
\end{tabular}

$\mathrm{p}=0.08$

Table 42. Farms in Naustdal, Norway, by leprosy status with median total farm rate, according to whether production of potatoes per person was below or above the median. (The National Leprosy Registry of Norway)

\begin{tabular}{|c|c|c|c|c|}
\hline \multirow[b]{2}{*}{$\begin{array}{l}\text { Production } \\
\text { of potatoes } \\
\text { per person }\end{array}$} & \multirow[b]{2}{*}{$\begin{array}{l}\text { Total } \\
\text { (No.) } \\
(\%)\end{array}$} & \multicolumn{2}{|c|}{ Leprosy status } & \multirow{2}{*}{$\begin{array}{l}\text { Total } \\
\text { farm } \\
\text { rate } \\
\text { (median) }\end{array}$} \\
\hline & & $\begin{array}{l}\text { L. positive } \\
\text { (No.) } \\
\text { (\%) }\end{array}$ & $\begin{array}{l}\text { L. negative } \\
\text { (No.) } \\
(\%)\end{array}$ & \\
\hline Below median & $\begin{array}{c}42 \\
100 \cdot 0\end{array}$ & $\begin{array}{l}30 \\
71 \cdot 4\end{array}$ & $\begin{array}{l}12 \\
28 \cdot 6\end{array}$ & $58 \cdot 0$ \\
\hline Above median & $\begin{array}{c}42 \\
100 \cdot 0\end{array}$ & $\begin{array}{l}25 \\
59 \cdot 5\end{array}$ & $\begin{array}{l}17 \\
40 \cdot 5\end{array}$ & $50 \cdot 0$ \\
\hline Total & $\begin{array}{c}84 \\
100 \cdot 0\end{array}$ & $\begin{array}{l}55 \\
65 \cdot 5\end{array}$ & $\begin{array}{l}29 \\
34 \cdot 5\end{array}$ & $55 \cdot 0$ \\
\hline
\end{tabular}

$\mathrm{p}=0 \cdot 18$ 
Table 43. Farms in Naustdal, Norway, by leprosy status with median total farm rate, according to whether production of milk per person was below or above the median. (The National Leprosy Registry of Norway)

\begin{tabular}{|c|c|c|c|c|}
\hline \multirow[b]{2}{*}{$\begin{array}{l}\text { Production } \\
\text { of milk } \\
\text { per person }\end{array}$} & \multirow[b]{2}{*}{$\begin{array}{c}\text { Total } \\
\text { (No.) } \\
(\%)\end{array}$} & \multicolumn{2}{|c|}{ Leprosy status } & \multirow{2}{*}{$\begin{array}{l}\text { Total } \\
\text { farm } \\
\text { rate } \\
\text { (median) }\end{array}$} \\
\hline & & $\begin{array}{l}\text { L. positive } \\
\text { (No.) } \\
(\%)\end{array}$ & $\begin{array}{l}\text { L. negative } \\
\text { (No.) } \\
(\%)\end{array}$ & \\
\hline Below median & $\begin{array}{c}43 \\
100 \cdot 0\end{array}$ & $\begin{array}{l}33 \\
76 \cdot 7\end{array}$ & $\begin{array}{l}10 \\
23 \cdot 3\end{array}$ & $80 \cdot 0$ \\
\hline Above median & $\begin{array}{c}41 \\
100 \cdot 0\end{array}$ & $\begin{array}{l}22 \\
53 \cdot 7\end{array}$ & $\begin{array}{l}19 \\
46 \cdot 3\end{array}$ & $28 \cdot 0$ \\
\hline Total & $\begin{array}{c}84 \\
100 \cdot 0\end{array}$ & $\begin{array}{l}55 \\
65 \cdot 5\end{array}$ & $\begin{array}{l}29 \\
34 \cdot 5\end{array}$ & $55 \cdot 0$ \\
\hline
\end{tabular}

$\mathrm{p}=0.02$

\section{Malnutrition}

In the last half of the 19th century barter economy was predominant in Naustdal as in rural Norway in general. Furthermore, the nutritional status of the population in Naustdal at the time was poor (Bidenkap, 1858; 1860). Under such conditions an association may be assumed to exist between production of a farm, i.e. oats, potatoes and milk, on one hand, and nutrition of its inhabitants on the other. Accordingly, data on production of each farm, derived from the general population censuses (vide 2.4.3), were used to ascertain whether leprosy was related to malnutrition.

Production of oats ranged from 0 to 11.4 production units (vide 2.5.5.) per person and the median was $5 \cdot 3$. Grouped according to the median, no association was demonstrated between production of oats per person and leprosy status of the farm, $p=0.08$ (Table 41). At farms where production of oats per person was low, median total farm rate was $53 \cdot 0$, while at farms where production was high, median total farm rate was $58 \cdot 0$.

Production of potatoes ranged from 0.9 to 10.0 production units per person, and the median was 3·0. Grouped according to the median, no association was demonstrated between production of potatoes per person and leprosy status of the farm, $p=0.18$ (Table 42). At farms where production of potatoes was low, median total farm rate was $58 \cdot 0$, while at the other farms, median total farm rate was $50 \cdot 0$.

Production of milk, based on number of cows (vide 2.5.5.), ranged from 3.8 to $18 \cdot 1$ production units per person, and the median was $8 \cdot 3$. Grouped according to the median, a significant association was demonstrated between production of milk per person and leprosy status of the farm, $p=0.02$ (Table 43). The frequency of leprosy positive farms was far higher among farms with a low production than among farms with a high production of milk, and median total farm rates were 80 and 28 respectively. 
Table 44. Farms in Naustdal, Norway, by leprosy status, with median total farm rate, according to whether total production per person was below or above the median. (The National Leprosy Registry of Norway)

\begin{tabular}{|c|c|c|c|c|}
\hline \multirow[b]{2}{*}{$\begin{array}{l}\text { Total } \\
\text { production } \\
\text { per person }\end{array}$} & \multirow[b]{2}{*}{$\begin{array}{l}\text { Total } \\
\text { (No.) } \\
(\%)\end{array}$} & \multicolumn{2}{|c|}{ Leprosy status } & \multirow[b]{2}{*}{$\begin{array}{l}\text { Total } \\
\text { farm } \\
\text { rate } \\
\text { (median) }\end{array}$} \\
\hline & & $\begin{array}{l}\text { L. positive } \\
\text { (No.) } \\
(\%)\end{array}$ & $\begin{array}{l}\text { L. negative } \\
\text { (No.) } \\
(\%)\end{array}$ & \\
\hline \multirow[t]{2}{*}{ Below median } & 42 & 32 & 10 & \multirow[t]{2}{*}{$67 \cdot 0$} \\
\hline & $100 \cdot 0$ & $76 \cdot 2$ & $23 \cdot 8$ & \\
\hline \multirow[t]{2}{*}{ Above median } & 42 & 23 & 19 & \multirow[t]{2}{*}{$37 \cdot 0$} \\
\hline & $100 \cdot 0$ & $54 \cdot 8$ & $45 \cdot 2$ & \\
\hline \multirow[t]{2}{*}{ Total } & 84 & 55 & 29 & \multirow[t]{2}{*}{$55 \cdot 0$} \\
\hline & $100 \cdot 0$ & $65 \cdot 5$ & $34 \cdot 5$ & \\
\hline
\end{tabular}

$\mathrm{p}=0.03$

Table 45. Farms in Naustdal, Norway, by total production per farm according to number of persons per farm

\begin{tabular}{cccc}
\hline & & \multicolumn{2}{c}{ Total production per person } \\
\cline { 3 - 4 } $\begin{array}{c}\text { Number } \\
\text { of persons }\end{array}$ & Total & $\begin{array}{c}\text { Above median } \\
(\text { No. })\end{array}$ & $\begin{array}{c}\text { Below median } \\
(\text { No. })\end{array}$ \\
per farm & $(\%)$ & $(\%)$ & $(\%)$ \\
\hline $1-20$ & 42 & 23 & 19 \\
& $100 \cdot 0$ & 54.8 & $45 \cdot 2$ \\
21 & 42 & 19 & 23 \\
& $100 \cdot 0$ & $45 \cdot 2$ & 54.8 \\
\hline Total & 84 & 42 & 42 \\
& $100 \cdot 0$ & $50 \cdot 0$ & $50 \cdot 0$ \\
\hline $\mathrm{p}=0.51$ & & &
\end{tabular}

Total production of the farm ranged from $7 \cdot 3$ to $35 \cdot 8$ production units per person, and the median was $16 \cdot 3$. Grouped according to the median, a significant association was demonstrated between total production of a farm and its leprosy status, $p=0.03$ (Table 44). Leprosy positive farms were far more frequent among farms with a low production than among the other farms, and median total farm rates were 67 and 37 respectively.

However, number of persons per farm ranged from 5 to 187 , and the median was 20. Obviously, the risk of having a leprosy patient on a farm, converting its leprosy status from negative to positive, was related to number of persons living at the farm. To find out whether the association between production and leprosy might be non-causal or secondary, and due to a possible negative correlation between production per person and number of persons per farm, the farms were tabled according to total production per person and number of persons per farm (Table 45). No association was demonstrated between the variables, $\mathrm{p}=0.51$. 
Table 46. Farms in Naustdal, Norway, by leprosy status with median total farm rate, according to whether farm index for production of oats and milk was below or above the median. (The National Leprosy Registry of Norway)

\begin{tabular}{|c|c|c|c|c|}
\hline \multirow[b]{2}{*}{$\begin{array}{l}\text { Farm index, } \\
\text { production of } \\
\text { oats and milk }\end{array}$} & \multirow[b]{2}{*}{$\begin{array}{c}\text { Total } \\
\text { (No.) } \\
(\%)\end{array}$} & \multicolumn{2}{|c|}{ Leprosy status } & \multirow{2}{*}{$\begin{array}{c}\text { Total } \\
\text { farm } \\
\text { rate } \\
\text { (median) }\end{array}$} \\
\hline & & $\begin{array}{l}\text { L. positive } \\
\text { (No.) } \\
(\%)\end{array}$ & $\begin{array}{l}\text { L. negative } \\
\text { (No.) } \\
(\%)\end{array}$ & \\
\hline Below median & $\begin{array}{c}42 \\
100 \cdot 0\end{array}$ & $\begin{array}{l}20 \\
47 \cdot 6\end{array}$ & $\begin{array}{l}22 \\
52 \cdot 4\end{array}$ & $1 \cdot 0$ \\
\hline Above median & $\begin{array}{c}42 \\
100 \cdot 0\end{array}$ & $\begin{array}{l}35 \\
83 \cdot 3\end{array}$ & $\begin{array}{c}7 \\
16 \cdot 7\end{array}$ & $74 \cdot 0$ \\
\hline Total & $\begin{array}{c}84 \\
100 \cdot 0\end{array}$ & $\begin{array}{l}55 \\
65 \cdot 5\end{array}$ & $\begin{array}{l}29 \\
34 \cdot 5\end{array}$ & $55 \cdot 0$ \\
\hline
\end{tabular}

$\mathrm{p}=0.0006$

+ A high index for a farm implies a high proportion of farm sections with a low production per person. (Vide 2.5.5.)

Table 47. Farms in Naustdal, Norway, by leprosy status with median total farm rate, according to whether tax value per farm section was below or above the median. (The National Leprosy Registry of Norway)

\begin{tabular}{|c|c|c|c|c|}
\hline \multirow[b]{2}{*}{$\begin{array}{l}\text { Tax value } \\
\text { per farm } \\
\text { section }\end{array}$} & \multirow[b]{2}{*}{$\begin{array}{c}\text { Total } \\
\text { (No.) } \\
(\%)\end{array}$} & \multicolumn{2}{|c|}{ Leprosy status } & \multirow{2}{*}{$\begin{array}{l}\text { Total } \\
\text { farm } \\
\text { rate } \\
\text { (median) }\end{array}$} \\
\hline & & $\begin{array}{l}\text { L. positive } \\
\text { (No.) } \\
(\%)\end{array}$ & $\begin{array}{l}\text { L. negative } \\
\text { (No.) } \\
(\%)\end{array}$ & \\
\hline \multirow[t]{2}{*}{ Below median } & 41 & 31 & 10 & \multirow[t]{2}{*}{$72 \cdot 0$} \\
\hline & $100 \cdot 0$ & $75 \cdot 6$ & $24 \cdot 4$ & \\
\hline \multirow[t]{2}{*}{ Above median } & 41 & 24 & 17 & \multirow[t]{2}{*}{$50 \cdot 0$} \\
\hline & $100 \cdot 0$ & $58 \cdot 5$ & $41 \cdot 5$ & \\
\hline \multirow[t]{2}{*}{ Total } & $82^{\dagger}$ & 55 & 27 & \multirow[t]{2}{*}{$55 \cdot 0$} \\
\hline & $100 \cdot 0$ & $67 \cdot 1$ & $32 \cdot 9$ & \\
\hline
\end{tabular}

Subsequently, the farms were grouped according to median farm index for total production, which was $0 \cdot 13$. A more significant association was demonstrated to exist between this independent variable and leprosy status of the farms, $p=0 \cdot 003$. Leprosy positive farms were far more frequent among the farms with a high farm index for total production than among the other farms, and median total farm rates were 74 and 0 respectively.

An even more significant association with the same trend was found to exist between farm index for production of oats and milk and leprosy status of the farms, $\mathrm{p}=0.0006$ (Table 46). 
Table 48. Farms in Naustdal, Norway, by leprosy status with median total farm rate, according to whether number of persons per house was below or above the median. (The National Leprosy Registry of Norway)

\begin{tabular}{|c|c|c|c|c|}
\hline \multirow[b]{2}{*}{$\begin{array}{c}\text { Persons } \\
\text { per } \\
\text { house }\end{array}$} & \multirow[b]{2}{*}{$\begin{array}{c}\text { Total } \\
\text { (No.) } \\
(\%)\end{array}$} & \multicolumn{2}{|c|}{ Leprosy status } & \multirow{2}{*}{$\begin{array}{c}\text { Total } \\
\text { farm } \\
\text { rate } \\
\text { (median) }\end{array}$} \\
\hline & & $\begin{array}{l}\text { L. positive } \\
\text { (No.) } \\
\text { (\%) }\end{array}$ & $\begin{array}{l}\text { L. negative } \\
\text { (No.) } \\
(\%)\end{array}$ & \\
\hline Below median & $\begin{array}{c}42 \\
100 \cdot 0\end{array}$ & $\begin{array}{l}27 \\
64 \cdot 3\end{array}$ & $\begin{array}{l}15 \\
35 \cdot 7\end{array}$ & $53 \cdot 0$ \\
\hline Above median & $\begin{array}{c}42 \\
100 \cdot 0\end{array}$ & $\begin{array}{l}28 \\
66 \cdot 7\end{array}$ & $\begin{array}{l}14 \\
33 \cdot 3\end{array}$ & $55 \cdot 0$ \\
\hline Total & $\begin{array}{c}84 \\
100 \cdot 0\end{array}$ & $\begin{array}{l}55 \\
65 \cdot 5\end{array}$ & $\begin{array}{l}29 \\
34 \cdot 5\end{array}$ & $55 \cdot 0$ \\
\hline
\end{tabular}

$$
\mathrm{p}=0 \cdot 50
$$

\section{Poverty}

Obviously, poverty, in an area with barter economy, is related to low production. However, further information on poverty was available. The tax value system was based on potential assets of the farm; i.e. potential optimal production in barn and fields (vide 2.4.3., 2.5.5.).

Tax value per farm section ranged from 84.9 to 619.0 oere, and the median was $252 \cdot 0$. Grouped according to the median, no significant association was demonstrated between tax value per farm section and leprosy status of the farm, $p=0.08$ (Table 47). At farms where tax value was low, median total farm rate was $72 \cdot 0$, while at the other farms, median total farm rate was $50 \cdot 0$.

\section{Overcrowding}

From studies on prevailing customs in this part of Norway, and particularly in Naustdal, it appears that the farm-houses differed little with respect to construction, number of rooms and size (Kloster, 1940). Accordingly, the variable 'number of persons per house' (vide 2.5.5.) might be used in comparisons between farms, being indicative of overcrowding.

Number of persons per house ranged from 3.5 to $10 \cdot 5$, and the median was 6.8. Grouped according to the median, no association was demonstrated between number of persons per house and leprosy status of the farm, $p=0.50$ (Table 48). At farms where number of persons per house was high, median total farm rate was 55.0 against 53.0 at the other farms.

Grouped according to median farm index for housing, (vide 2.5.5.), 0.25, still no association was demonstrated, $\mathrm{p}=0 \cdot 33$, and median total farm rate was almost the same in the two groups, $56 \cdot 0$ and 50.0 (Table 49). 
Table 49. Farms in Naustdal, Norway, by leprosy status with median total farm rate, according to whether farm index for housing was below or above the median. (The National Leprosy Registry of Norway)

\begin{tabular}{|c|c|c|c|c|}
\hline \multirow[b]{2}{*}{$\begin{array}{c}\text { Farm } \\
\text { index, } \\
\text { housing }{ }^{\dagger}\end{array}$} & \multirow[b]{2}{*}{$\begin{array}{l}\text { Total } \\
\text { (No.) } \\
(\%)\end{array}$} & \multicolumn{2}{|c|}{ Leprosy status } & \multirow{2}{*}{$\begin{array}{c}\text { Total } \\
\text { farm } \\
\text { rate } \\
\text { (median) }\end{array}$} \\
\hline & & $\begin{array}{l}\text { L. positive } \\
\text { (No.) } \\
(\%)\end{array}$ & $\begin{array}{l}\text { L. negative } \\
\text { (No.) } \\
(\%)\end{array}$ & \\
\hline Below median & $\begin{array}{c}45 \\
100 \cdot 0\end{array}$ & $\begin{array}{l}28 \\
62 \cdot 2\end{array}$ & $\begin{array}{l}17 \\
37 \cdot 8\end{array}$ & $50 \cdot 0$ \\
\hline Above median & $\begin{array}{c}39 \\
100 \cdot 0\end{array}$ & $\begin{array}{l}27 \\
69 \cdot 2\end{array}$ & $\begin{array}{l}12 \\
30 \cdot 8\end{array}$ & $56 \cdot 0$ \\
\hline Total & $\begin{array}{c}84 \\
100 \cdot 0\end{array}$ & $\begin{array}{l}55 \\
65 \cdot 5\end{array}$ & $\begin{array}{l}29 \\
34 \cdot 5\end{array}$ & $55 \cdot 0$ \\
\hline
\end{tabular}

$\mathrm{p}=0 \cdot 33$

† A high index for a farm implies a high proportion of farm sections with a high number of persons per house. (Vide 2.5.5.).

Table 50. Farms in Naustdal, Norway, by leprosy status with median total farm rate, according to whether sphagnum index was below or above the median. (The National Leprosy Registry of Norway)

\begin{tabular}{|c|c|c|c|c|}
\hline \multirow[b]{2}{*}{$\begin{array}{l}\text { Sphagnum } \\
\text { index }\end{array}$} & \multirow[b]{2}{*}{$\begin{array}{c}\text { Total } \\
\text { (No.) } \\
(\%)\end{array}$} & \multicolumn{2}{|c|}{ Leprosy status } & \multirow{2}{*}{$\begin{array}{c}\text { Total } \\
\text { farm } \\
\text { rate } \\
\text { (median) }\end{array}$} \\
\hline & & $\begin{array}{l}\text { L. positive } \\
\text { (No.) } \\
(\%)\end{array}$ & $\begin{array}{l}\text { L. negative } \\
\text { (No.) } \\
(\%)\end{array}$ & \\
\hline Below median & $\begin{array}{c}39 \\
100 \cdot 0\end{array}$ & $\begin{array}{l}18 \\
46 \cdot 2\end{array}$ & $\begin{array}{l}21 \\
53 \cdot 8\end{array}$ & 0 \\
\hline Above median & $\begin{array}{c}40 \\
100 \cdot 0\end{array}$ & $\begin{array}{l}32 \\
80 \cdot 0\end{array}$ & $\begin{array}{c}8 \\
20 \cdot 0\end{array}$ & $71 \cdot 6$ \\
\hline Total & $\begin{array}{c}79 \\
100 \cdot 0\end{array}$ & $\begin{array}{l}50 \\
63 \cdot 3\end{array}$ & $\begin{array}{l}29 \\
36 \cdot 7\end{array}$ & $55 \cdot 0$ \\
\hline
\end{tabular}

$p=0.002$

\section{Sphagnum vegetation}

Sphagnum index ranged from $-1 \cdot 88$ to $+1 \cdot 66$, and the median was $+0 \cdot 15$. For 5 farms data necessary for the calculation of a sphagnum index were lacking.

When the farms were grouped according to median sphagnum index, a significant association was demonstrated between sphagnum index and leprosy status of the farm, $p=0.002$ (Table 50). The frequency of leprosy positive farms was far higher among the farms with a high sphagnum index than among the other farms, and median total farm rates were 72 and 0 respectively. 
Table 51. Extent of correct classification and ratio of risks in different groups of farms in Naustdal, Norway. Groups defined by discriminant functions for sphagnum variables, farm variables and all variables pooled together and an optimal cut-off point. (The National Leprosy Registry of Norway)

\begin{tabular}{|c|c|c|c|}
\hline \multirow[b]{2}{*}{ Discriminant function } & \multicolumn{3}{|c|}{ Leprosy status of farm } \\
\hline & $\mathrm{L}+$ & $\mathrm{L}-$ & Total \\
\hline \multicolumn{4}{|l|}{ Sphagnum variables } \\
\hline Above cut-off point & 44 & 11 & 55 \\
\hline Below cut-off point & 6 & 16 & 22 \\
\hline Total & 50 & 27 & 77 \\
\hline \multicolumn{4}{|l|}{$\begin{array}{l}\text { Correctly classified: } 77 \cdot 9 \% \\
\text { Ratio of risks: } 2 \cdot 9\end{array}$} \\
\hline \multicolumn{4}{|l|}{ Farm variables } \\
\hline Above cut-off point & 39 & 9 & 48 \\
\hline Below cut-off point & 11 & 18 & 29 \\
\hline Total & 50 & 27 & 77 \\
\hline \multicolumn{4}{|l|}{$\begin{array}{l}\text { Correctly classified: } 74 \cdot 0 \% \\
\text { Ratio of risks: } 2 \cdot 1\end{array}$} \\
\hline \multicolumn{4}{|l|}{$\begin{array}{l}\text { Sphagnum variables } \\
+ \text { Farm variables }\end{array}$} \\
\hline Above cut-off point & 46 & 11 & 57 \\
\hline Below cut-off point & 4 & 16 & 20 \\
\hline Total & 50 & 27 & 77 \\
\hline $\begin{array}{l}\text { Correctly classified: } 80 \cdot 5 \% \\
\text { Ratio of risks: } 4 \cdot 0\end{array}$ & & & \\
\hline
\end{tabular}

\section{A comparison of environmental variables}

For a total of 77 farms data on all farm- and sphagnum-variables were used as a basis for discriminant analyses. Data from 7 farms were not used in the analyses, in part due to incomplete information, in part because the farm was considered too big (vide 3.6.4.).

The relative importance of the 7 variables used in the construction of the sphagnum index was assessed by a stepwise analysis. According to the analysis, water supply (var. 7) was the variable which alone had the best discriminating power, $p=0.002$. The variable which, in addition to the first, gave the best discriminating power was sphagnum vegetation (var. 1). The significance of change was $p=0.007$ and the significance of the total function was $p=0.001$. Addition of the next variable did not produce a significant change, and the analysis was ended.

The total function, based on all 7 sphagnum variables, was assessed by its ability to classify correctly the farms as leprosy positive or negative (Table 51). 
At the optimal cut-off point, $60(77.9 \%)$ of the 77 farms were correctly classified. The risk that farms, with a value of the function exceeding the cut-off point, were leprosy farms (vide 2.5.5.), was 2.9 times higher than the risk of being a leprosy farm for those below the cut-off point.

In a stepwise analysis based on the 3 farm variables, farm index for production of oats and milk, tax value, and farm index for housing, farm index for production of oats and milk was the variable which alone had the best discriminating power, $p=0.02$. Addition of further variables did not produce a significant change.

By the total function based on all 3 farm variables and an optimal cut-off point, $57(74.0 \%)$ of the 77 farms were correctly classified. The ratio of risks was $2 \cdot 1$.

According to a stepwise analysis, based on all 10 variables, water supply was the variable which alone had the best discriminating power, $p=0 \cdot 002$. By adding the next variable, farm index for production of oats and milk, the significance of change was $\mathrm{p}=0.005$ and the significance of the total function was $\mathrm{p}<0.001$. The next variable to be added was orientation of the vegetation which also produced a significant change, $p=0 \cdot 01$. Addition of the next variable did not produce a significant change, and the analysis was ended.

By a total function based on all 10 variables and an optimal cut-off point, $62(80.5 \%)$ of the 77 farms were correctly classified. The ratio of risks was $4 \cdot 0$.

\subsubsection{COMMENTS}

In this part of the study, the farm rather than the person was chosen the unit of observation, first of all because the intention was to pinpoint characteristics of minor localities with leprosy compared with localities without leprosy. The environmental variables to be studied were attached to the farm and not to the person.

Furthermore, elaborate calculations based on persons, e.g. calculation of risk ratios, would have been hampered by the lack of an exact denominator, viz. total number of persons at risk throughout the observation period. However, for the mere calculation of rates, e.g. total farm rate, an average total population was considered a satisfactory denominator. On the other hand, using the farm as the unit of observation, the exact denominator was known.

The possibility that the occurrence of leprosy could be secondarily associated with production/nutrition might hypothetically be the effect, on one hand, of a primary positive association between number of persons per farm and leprosy status of the farm and, on the other hand, of a primary negative association between number of persons per farm and production. Accordingly, one would expect a significantly lower production per person at farms with many inhabitants. Furthermore, one would expect only minor differences between total farm rates of farms with high and low production, because leprosy would occur particularly at farms with many inhabitants. However, no 
significant association was found to exist between production per person and number of inhabitants, and also the rates were far higher at farms where production per person was low. In an additional attempt to avoid the bias, that a larger farm inevitably would have a higher risk of being a leprosy farm, solely due to a higher number of inhabitants, farms with more than 100 inhabitants were not included in the analyses. Besides, a general description with respect to environmental variables, of such a large farm as one entity, would hardly seem satisfactory. Accordingly, it may be concluded that the association demonstrated to exist between leprosy status of the farm and low production/malnutrition was not such a secondary association.

Obviously, the possibility should not be neglected, that a low production might represent the effect of leprosy and not a causal factor. This is, however, not very likely, because total number of patients present at any one farm at any time was rather small compared with total number of inhabitants, even at high frequency farms. E.g., even at the 2 farms with the highest total farm rates, 428.6 and 385.0 respectively, only 2 patients lived at the farms at the time of the census in 1865 , and the total population was 27 . Furthermore, the patients living at the farms were probably not much disabled; disabled patients were sent to hospital. Thus, the loss of labour, due to disabled patients living at the leprosy positive farms, lowering the production per person, was considered small.

The associations between leprosy status and farm indices for production were stronger and more significant than the associations between leprosy status and mere production per person. This implies that the variable 'production per person' at farm level in fact covered a wide range from the most wealthy to the most poor farm sections within one farm.

Even in an area with barter economy, leprosy did not appear to be associated with mere assets. This finding seems to affirm that the association between leprosy and production at the farms was less related to the economical value of the production than to its nutritional aspects.

The construction of the sphagnum index was based on two different components. The first was related to conditions for growth of mycobacteria in sphagnum vegetation observed at the farms today. The alternative, to relate this component to the occurrence today at different localities of specified mycobacteria in the sphagnum vegetation (Kazda et al., 1979), might also be useful. However, the mycobacterial composition of the vegetation today is not necessarily the same as in the last century, while the conditions for growth apparently have not changed much during the last 100 years.

The second component, referred to in the construction of the sphagnum index, was the inhabitants' access to the vegetation.

From an ecological point of view, it was interesting to note that the most important variables in the stepwise analyses were related to different components, i.e. both components used in the sphagnum index appeared to be relevant in the analyses. Furthermore, in analyses based on a pool of all 
sphagnum- and farm-variables, variables related to the two components were chosen as the most important, together with the variable for production.

The possibility is not very likely, that the positive association between sphagnum index and the occurrence of leprosy might be secondary, caused by primary negative associations, on one hand between sphagnum index and production, and on the other hand between production and occurrence of leprosy. On the contrary, the construction of the sphagnum index was based on conditions which would favour growth of vegetation in general (i.e. also production) as well as growth of mycobacteria in sphagnum vegetation. 



\section{Discussion}

\subsection{General background}

Exposure to $M$. leprae seems to represent a generally accepted factor or agent, necessary to contract leprosy. However, it appears that only a minor proportion of exposed persons develop the disease (Leiker, 1977; Davey, 1978). Furthermore, immunological techniques have demonstrated that a large number of persons exposed, may even become infected, but without developing any signs or symptoms (Godal and Negassi, 1973).

In general, immunological studies during the last decade have brought a considerable amount of knowledge of the pathogenesis of leprosy, and in particular many details on the nature of the immunological deficiency in lepromatous leprosy are revealed (Godal et al., 1974, Godal, 1978a). Protective immunity in leprosy, a disease with intracellular multiplication of bacteria, is considered to be due to cell mediated immune reactions, though the role played by humoral antibodies does not yet seem to be clear. In lepromatous leprosy there is a T-lymphocyte associated defect in responses to M. leprae; however, the precise mechanism behind the defect is still unknown.

Far less is known of the cause of this lack of protective immunity. Apparently, M. leprae is not a sufficient aetiological factor; additional factors are decisive as to whether an exposed person is to contract leprosy or not. The differentiation of the disease into separate types is also caused by such additional factors. On this basis a comprehensive discussion has evolved over several decades.

Put simply, additional factors of possible relevance may relate to the host or the agent (Doull, 1962). Factors relating to the host refer to terms like 'susceptibility' and 'resistance'; terms until now used mainly for theoretical discussions. From an epidemiological point of view, knowledge of the substance of these terms and their practical implications is still scarce. Nevertheless, the use of the term 'susceptibility' in the epidemiological discussion of additional factors may prove fruitful. Factors attached to the host may be of environmental origin like poverty, malnutrition and poor hygiene. Furthermore, factors attached to the host may be of genetic origin.

Factors attached to the agent may relate to qualitative aspects, like different strains of $M$. leprae with variations in pathogenicity; e.g. recently, primary dapsone-resistant strains appear to have been demonstrated (Meade, 1977). Or the factors may relate to quantitative aspects, i.e. dose and duration 
of the exposure. Furthermore, quantitative aspects may even represent an environmental factor attached to the host; increasing evidence seems to suggest that dose and duration of exposure may influence the susceptibility of the host (Godal, 1978b).

In the strict sense of the word, risk of exposure represents no aetiological factor. Still, risk of exposure should be taken into account in epidemiological analyses of leprosy. However, to separate quantitative aspects related to the agent from risk of exposure is often difficult. Furthermore, factors which are often considered as environmental, may also be related to risk of exposure; e.g. sociological patterns of males and females.

Probably, most of the different types of factor mentioned may be relevant to the aetiology of leprosy. Accordingly, the task of the epidemiologist is not to pinpoint the one of all the possible factors that is effective and exclude all the others. Although perhaps impossible at the present stage, his task should be to assess the relative importance of the different factors in an attempt to form a basis for prevention of the disease.

\subsection{Interpretations and inferences}

\subsubsection{GEOGRAPHICAL DISTRIBUTION}

Striking geographical differences in morbidity rates were observed in Norway. In areas with approximately one half of the population, the disease was almost unknown, while in the rest of the country, leprosy represented a serious public health problem.

\section{Communications}

This finding might be related to different risks of exposure due to geographical differences in patterns of communication. During the observation period the majority of the traffic was by ship; water represented traffic arteries while inland and mountains represented barriers. Probably, passenger traffic was far more extensive in districts with high rates, i.e. in districts near the sea (Table 13). This was particularly important for the population occupied in the fisheries of West and North Norway. The finding of relatively numerous cases in health districts of the low frequency areas near the county with the highest rates, is consistent with a higher risk of exposure. The overland traffic occurring between high and low frequency areas, passed through these districts.

Yet, patterns of traffic cannot explain the difference in rates between rural districts and towns, nor the fact that leprosy was almost unknown in East Norway, even in districts close to the sea. 


\section{Mycobacteria in the environment and tuberculosis}

However, a hypothesis based on the finding of cultivable and non-cultivable mycobacteria in sphagnum bog vegetation in West Norway today (Kazda et al., 1979) seems to be consistent with the geographical distribution of leprosy in Norway. The non-cultivable mycobacteria have still not been identified, but the hypothesis suggests an influence of these micro-organisms on the occurrence of leprosy, either as a pathogen or, more likely, as an additional factor perhaps influencing susceptibility. Growth of these mycobacteria is, among other factors, dependent on humidity and temperature (Kazda, 1979).

A high relative humidity, important both to growth of sphagnum vegetation and mycobacteria, is related to regional conditions, such as rainfall. It appears that the area in Norway with a mean relative humidity in the air in July higher than $75 \%$, coincides, to a striking extent, with the area of the high frequency regions (Figs. 1 and 12, Table 16). The lack of association in Naustdal, the health district with the highest morbidity rates, between a farm's distance from the sea and the occurrence of leprosy at the farm was also in favour of the concept that the sea, per se, was of minor importance.

A high temperature, most important for the growth of mycobacteria, is mostly influenced by local conditions and may, independent to some extent of air temperature, rise to optimal levels in localities where accumulation of solar energy is possible; e.g. in localities where orientation and slope of the ground are favourable. Accordingly, an association, at country level, between air temperature and morbidity rates might not be expected; neither was this found. On the other hand, at the local level, an association was demonstrated between the occurrence of leprosy and conditions favouring a sufficiently high temperature in the vegetation, documented by the sphagnum index and also by the finding of a higher rate on the northern bank of the fjord, which in general is more exposed to the sun than the southern bank.

If the geographical distribution of leprosy in Norway were related to the finding of mycobacteria in the environment, most probably the mechanism would be that these micro-organisms interfere with the induction of protective immunity induced by $M$. leprae itself. This would be consistent with a hypothesis introduced by Stanford and his colleagues (Shield and Stanford, 1977; Godal, 1978b) who suggest that slow-growing mycobacteria may possess such a property of interference.

Besides, the importance in the epidemiology of leprosy of viable $M$. leprae outside the human body has recently been stressed, in part since M. leprae appears to be able to survive more than 1 week after excretion through nose blows (Desikan and Sreevatsa, 1978) in part since leprosy may represent an indigenous disease in wild armadillos (Walsh et al., 1975; Skinsnes, 1976b).

In the discussion of the geographical distribution, the occurrence of tuberculosis in Norway should be briefly mentioned. The first reliable mortality rates of tuberculosis in Norway refer to the period 1881-85 (Backer, 1961). Of 
Table 52. Annual mortality rates of tuberculosis 1881-85 and incidence rates of leprosy $1881-90$ per 100,000 in the counties of the high frequency areas. (Central Bureau of Statistics and The National Leprosy Registry of Norway)

\begin{tabular}{|c|c|c|}
\hline County & $\begin{array}{c}\text { Annual } \\
\text { mortality rate } \\
\text { of tuberculosis } \\
\text { per } 100,000 \\
1881-85\end{array}$ & $\begin{array}{c}\text { Annual } \\
\text { incidence rate } \\
\text { of leprosy } \\
\text { per } 100,000 \\
1881-90\end{array}$ \\
\hline Rogaland & 510 & 0.9 \\
\hline Hordaland & 300 & $4 \cdot 9$ \\
\hline Sogn \& Fjordane & 160 & $12 \cdot 4$ \\
\hline Mфre \& Romsdal & 220 & $6 \cdot 4$ \\
\hline S. Tr $\phi$ ndelag & 330 & $6 \cdot 7$ \\
\hline N. Tr $\phi$ ndelag & 270 & $7 \cdot 6$ \\
\hline Nordland & 220 & $10 \cdot 8$ \\
\hline Troms & 210 & $3 \cdot 3$ \\
\hline Finnmark & 270 & $3 \cdot 3$ \\
\hline
\end{tabular}

all counties in Norway, Sogn \& Fjordane, the county with the highest incidence rates of leprosy, had the lowest mortality rates of tuberculosis (Table 52). (It should be noted, however, that even in this county, mortality rates of tuberculosis were far higher than the highest incidence rates of leprosy registered in the county.) Furthermore, in the other counties where incidence rates of leprosy were high, mortality rates of tuberculosis were relatively low. If this association were involved in the aetiology of leprosy, the explanation might be that M. tuberculosis (as a fast-growing mycobacterium) induces protective immunity against leprosy, as BCG appears to do under special conditions (Godal, 1978b; Shield and Stanford, 1977). The hypothesis that leprosy and tuberculosis are inversely related, is not new and has been advocated by several authors (Chaussinand, 1948; Davey, 1975), though doubted by others due to lack of a clear negative correlation between rates of leprosy and tuberculosis in a number of countries studied (Newell, 1966). A discussion of the validity of these statistics is beyond the scope of this study. Yet, the hypothesis seems to be consistent with the epidemiological development of leprosy and tuberculosis in Norway, and also with the suggestion that mycobacteria, other than M. leprae, are relevant in the aetiology of leprosy.

The geographical distribution of leprosy in Norway differed considerably, not only from region to region, but also at county, health district-, village- and farm-level. Apparently, this represents a general feature of the epidemiology of the disease (Leiker, 1960; Doull, 1962; Newell, 1966; Bechelli and Martinez Dominguez, 1972; Lechat, 1973; Ratard and Bravo, 1978; among others). While the geographical distribution of leprosy in other parts of the world apparently exhibits the same gross features as in the present study, it is obviously impossible to say whether the distribution in these countries is influenced by the same 
environmental variables. At this stage it should be stated that further research in the fields of immunology, bacteriology and epidemiology is necessary to enlarge upon the hypotheses on tuberculosis and other mycobacteria as additional factors, and to assess the relevance of these hypotheses to primary prevention.

\section{Malnutrition}

Apart from occurring particularly in localities at which conditions for growth in spagnum vegetation of mycobacteria were good, leprosy at the local level, was also associated with production of food at the farms. Lack of association with tax value seemed to indicate that nutritional aspects of the production were essential. On the other hand, a weaker association with production of potatoes than with production of milk and oats should not, without further consideration, be interpreted in favour of a specific protein-deficiency as a factor. The lack of association with production of potatoes may be due to a pattern of production in which potatoes apparently represented the basic product of much the same quantity per person at each farm, and oats represented the excess, particularly found at farms with a high production of food. On the other hand, the finding does not exclude the influence of a protein-deficiency, which has been advocated by several authors (Chandra, 1974; Skinsnes, 1976a).

Today, malnutrition in Norway may seem strange, and it may be doubted that this factor played any significant part in the aetiology of leprosy. However, nutritional conditions as well as living conditions in general were far from fair in Norway in the middle of the last century, particularly in parts of the country where leprosy was prevalent. This is stated not only by doctors travelling around the districts in search for aetiological clues (Hjort, 1871; Bidenkap, 1858; 1860; Hansen, 1874), but also by Eilert Sundt (e.g. 1869) in his pioneer sociological studies on living conditions in Norway.

\section{Overcrowding}

No association was demonstrated to exist between overcrowding and leprosy, even if the range of number of persons per house was considerable. This finding appears to be contrary to the associations found in Cordova (Doull et al., 1936) and Talisay (Guinto and Rodriguez, 1941) in the Philippines, however, the associations reported were apprently not strong. (The results are not comparable).

Obviously, all persons living in a household together with an infectious patient, are exposed to $M$. leprae. However, it seems reasonable to assume that if close physical skin to skin contact, e.g. sharing a bed, is necessary for the transmission of the disease, overcrowding might represent an additional factor. On the other hand, if direct contact is not necessary, the disease may propagate to susceptible members in a family irrespective of overcrowding. Accordingly, 
the findings agree with the hypothesis that nasal discharge with droplets represents a potent source of infection. Route of entry, however, cannot be clarified by the present material.

\section{Genetic factors}

In iteself the geographical distribution is compatible with a genetic background; high levels of inbreeding for instance, were frequent in Norway in the last century. However, genetic factors can certainly not be related to the extremely rapid decline of leprosy in Norway, occurring over 70 years.

\subsubsection{DECLINE}

The separate leprosy censuses of 1836 and 1845, together with time trends of morbidity and morality rates, appear to document that peak rates occurred at the middle of the century, though the disease had previously been endemic in the high frequency regions. Subsequently, a continuous and increasing decline was registered. This conspicuous decline has aroused justified attention in Norway and abroad (Lie, 1929; Doull, 1962; Davey, 1975; Skinsnes, 1975, among others); justified because this experience proves that leprosy, under certain conditions, may disappear from a population during a few generations, but also challenging because of evident implications for primary prevention.

Obviously, some of the possible additional factors already discussed, might have been relevant also to the rapid decline in morbidity rates.

\section{Malnutrition}

No doubt, the nutritional conditions in the high frequency regions greatly improved during the latter half of the 19th century, presumably rendering the population less susceptible to leprosy.

\section{Mycobacteria in the environment and tuberculosis}

The influence of possible environmental mycobacteria was probably reduced during the period because extensive new ground was cleared, increasing the distance from the farm houses to localities with favourable conditions for growth of mycobacteria. The risk of contact with such sources also diminished since the use of boots, even in summer, became more and more common, and since wells were used for provision of drinking water instead of brooks and bogs.

Morbidity rates of tuberculosis increased until beyond the turn of the century, and the increase was relatively high in the high frequency regions. Accordingly $M$. tuberculosis was more widespread in the population than previously, diminishing, according to the hypothesis, its susceptibility to leprosy. 


\section{Emigration}

Emigration to the USA seemed to represent a special factor responsible for the rapid decline in morbidity rates. Emigration was particularly frequent in those counties, and in those age- and sex-groups, with particularly high incidence rates. In spite of this fact, and even though several patients with leprosy also emigrated, the disease never propagated in the USA (Aycock, 1940; Lie, 1938; Boeck, 1871; Holmboe, 1865; Washburn, 1950) presumably since new environmental conditions reduced the susceptibility of the emigrants.

\section{Isolation}

In the discussion of the effects of isolation, a concept relating to differences between infection in the household and infection in the community at large should be introduced. The concept, which has previously been applied in a most interesting and fruitful way by Doull and colleagues (1947), implies that the disease, both from an epidemiological and a preventive point of view, acts differently when it occurs in the household and in the community at large. The difference does not relate only to risk of exposure, but to the hypothesis that dose and duration of exposure represent an additional factor, influencing the susceptibility of the individual at risk. The hypothesis is supported by studies with the lymphocyte transformation test (Godal and Negassi, 1973) and with skin tests (Shield et al., 1977).

Accordingly, it seems reasonable to infer that the removal from a household of all infectious patients, would greatly diminish the risk of the remaining persons, though infected, of contracting clinical disease. On the other hand, the removal of a patient from the community at large would, to a negligible extent, reduce the risk of the population, i.e. persons belonging to other households, of contracting clinical disease. As long as infectious patients remain in the community, susceptible individuals may be infected and contract the disease, even if the dose is low and the duration of exposure is short.

There is strong evidence which supports the assumption that leprosy may be transmitted in these two different ways; and relative attack rates have been calculated for groups consisting of persons in infected households and for groups without known exposure. (Guinto et al., 1954; Rao et al., 1975).

Thus, in an epidemiological situation characterized by a high relative importance of infection in the household, i.e. when a high number of households is affected and prevalence rates are high, isolation may cause a fall in subsequent incidence rates. However, when prevalence rates are low, and the relative importance of infection in the community is higher, due to a lower occurrence of infection in the household, the effects of isolation may be low. This is consistent with the results of the present study. Accordingly, physical isolation in Norway of infectious patients in special leprosy hospitals is considered an important cause of the initial decline in incidence rates during the observation period. 
To state a level of prevalence, indicating in general under which conditions isolation may be effective, is not possible since prevalence should relate to infectious cases. Until now, doubt has been thrown on the assumption that all tuberculoid cases should be considered non-infectious (Godal et al., 1974; Rao et al., 1975) and for the Leprosy Registry it seems reasonable to believe that risk of infection applied also to other than type 1 cases (vide 4.2.4.). Furthermore, today only theoretical interest is attached to the question of such a prevalence level. As stated previously, there is no longer need for this measure in leprosy control.

However, the material may clarify a question of considerable practical importance for today. The present findings, as well as results of evaluation studies of 'chemical isolation' (Rasi et al., 1975), are consistent with the concept that dose and duration of exposure play important parts in the aetiology of leprosy, by which a rationale for medical treatment as primary prevention is established. If a project of chemical isolation seems inefficient, the reason is probably not that the index cases have infected contacts before chemical isolation of the index cases is obtained; most likely they have. The reasons should be sought in problems relating to compliance or drug resistance, which today represent serious obstacles in leprosy control (Meade, 1977).

It is interesting to note that objections against the Norwegian control policy were already raised at an early stage, and not only based on humanitarian considerations. Hutchinson (1906), in defence of his fish-eating hypothesis, argued that the degree of isolation was too low (in fact underestimated by him) to influence incidence rates. If isolation was to affect transmission in the community at large, the argument might have been valid. However, it appeared that isolation was effective even when less than $50 \%$ of the cases were admitted to hospital.

Thus Skinsnes (1975) suggested, on the basis of experience from Hawaii, Taiwan and Hong Kong, that a similar effect may be expected when chemotherapeutic segregation is available, even to less than $50 \%$ of indigenous cases, in a community similar to the Norwegian, i.e. a community of rapidly rising standards of living.

On the basis of most elegant epidemiometric models, Lechat and colleagues (1977) doubted the efficiency of isolation. However, differences with respect to assumptions made on practice of isolation, and differences with respect to epidemiological conditions in Norway and India, where data for calculation of the parameters in the models were obtained, (Lechat, 1971, Lechat et al., 1974) seem to impede further comparisons. Networks of contacts, for instance, are supposed to be more comprehensive and involving more persons in India than at remote farms in Norway, and this may influence the efficiency of isolation.

\subsubsection{SEX, AGE AND TYPE}

In the discussion of sex, age and type, further consequences of the concept of infection in the household and infection in the community will be outlined. 
From a theoretical point of view infection in the household is associated with a low mean age at onset; the children are infected at an early age. The sex ratio is close to 100 ; risk of exposure is equal in males and females. Type index is high; dose and duration of exposure, probably important to host responses provoked and to the differentiation into types (Godal and Negassi, 1973; Shield and Stanford, 1977), are high. Infection in the household is relatively predominant when morbidity rates are high, as in the first part of the observation period in Norway and particularly in Naustdal.

Infection in the community is associated with a high age at onset due to a postponement of the time of infection. Sex ratio is dependent on sociological patterns. However, if males, due to work, have more extensive contacts outside the home than females, as in Norway in the last century, sex ratio will be high. Type index is low; dose and duration of exposure is low. Infection in the community is relatively predominant when morbidity rates are low, as in the last part of the observation period and particularly in the low frequency areas.

The present results indicated that mean age at onset, sex ratio and type index of new cases of leprosy in Norway, varied in accordance with the theoretical concept, as shown in the following.

\section{Age-specific incidence rates}

Apparently, the trend in age-specific incidence rates with a peak in young adults (Fig. 16), is in part due to varying lengths of the incubation period, e.g. age at onset is postponed in type 1 patients because the incubation period appears to be longer (Feldman, 1973; Godal et al., 1974). Thus, only patients with a short incubation period will be registered in the youngest age group. Later, patients with both short and long incubation periods will be registered.

In part the trend is influenced by different risks of exposure in different age groups.

Accordingly, the low incidence rates in the age group 0-14 years represent (mostly benign) cases infected in their households, while the higher rates between 15 and 50.years of age represent in part (malignant) cases infected in their households, in part cases infected in the community. The lower rates in the age group over 50 years are most probably due to a lower risk of exposure, and particularly since the rate in the females is lower than the rate in males. However, in part the result may be caused by the relatively low frequency of patients with extraordinarily long incubation periods.

An interesting interpretation by Bechelli and colleagues (1973), who suggest that the lower prevalence rates in high age groups are due to the possibility that persons who may have had incubating infections, do not live long enough to present signs of the disease, is hardly tenable. Obviously, number of cases may be reduced due to this reason, but if the mortality rates during incubation are no higher than in the general population, the incidence rates are not influenced. However, provided mortality rates of leprosy patients increase more by 
age than those of the total population, prevalence rates will be further diminished, as observed by Bechelli and colleagues.

\section{Age-specific incidence rates and level of incidence}

The trend in age-specific incidence rates and mean age at onset by average incidence rate (Table 38, Table 39, Fig. 33) with a low mean age at onset in high rate areas and vice versa, may, according to the concept, be related to increased exposure in young age groups when the incidence rates are high, i.e. in the household. The trend might have been even more marked if infection in the household was not associated with a high relative frequency of malignant cases with long incubation periods.

\section{Age-specific incidence rates according to year of onset and year of birth}

Different trends are found in age-specific incidence rates and mean age at onset by calendar year, dependent on whether tabulations are based on year of onset or year of birth (Figs. 19-24).

According to Sartwell (1950) the frequency curve of incubation time in general takes the form of a logarithmic normal curve. This appears to be equally true of diseases with very short and very long incubation periods. Thus, leprosy cases with extremely long incubation periods, e.g. 20-30 years, exist, but they are infrequent compared with total number of cases infected at the same time. However, towards the end of the observation period in Norway, when incidence rates were low, patients with a long incubation period, infected when the rates were far higher, were more frequent compared with the other patients taken ill at the same time, i.e. at the end of the observation period. Accordingly, mean age at onset increased by calendar year of onset. However, registered during a period with an increasing relative importance of infection in the community, the trend was most probably also due, to some extent, to the postponement of time of infection to a higher age group.

The opposite trend, registered in consecutive birth cohorts has also been demonstrated in other leprosy materials (Feldman and Sturdivant, 1975). The trend is attributable to the fact that the first period of life in each cohort, due to the rapid fall in morbidity rates, to an ever increasing extent, is the period with the highest risk of exposure. This finding implies that also adults may be infected and subsequently taken ill. Accordingly, trends in age-specific incidence rates are not only influenced by the lengths of incubation periods. However, postponement of infection to a higher age group towards the end of the observation period did not represent a characteristic feature. A decreasing age at onset in consecutive birth cohorts will always occur when aetiological factors are removed from a population, due to a younger age of infection. Analyses of mortality rates of tuberculosis in Norway have given similar results (Backer, 1961). 


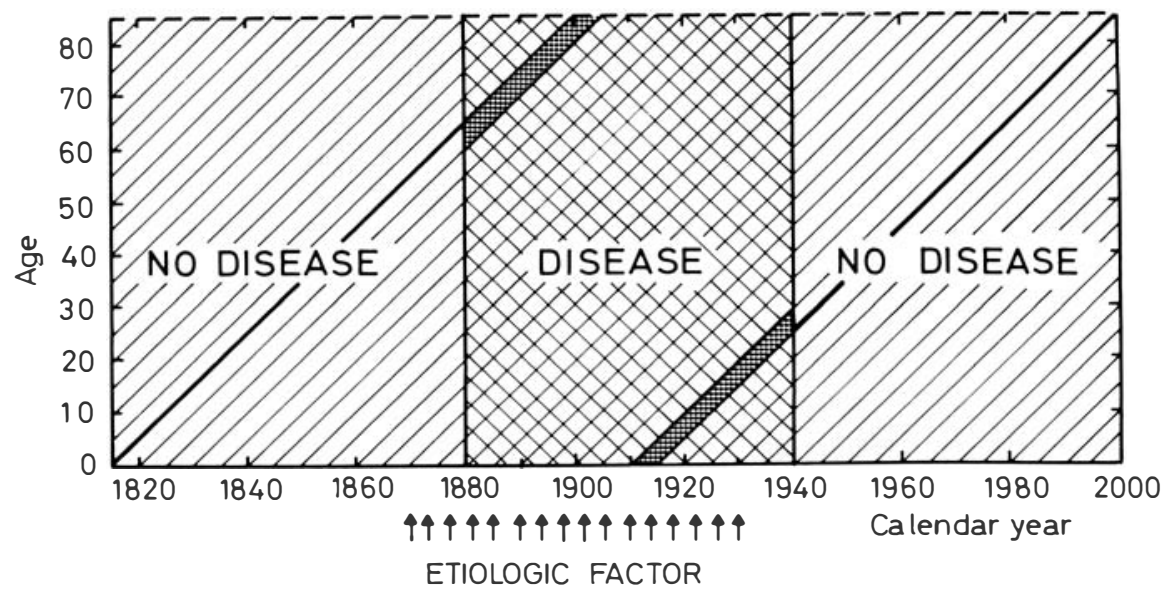

Figure 35. Lexis' table modified for illustration, in a simplified way, of the occurrence in consecutive birth cohorts of a disease by age, according to the time at which the cohorts were influenced by an aetiological factor.

On the other hand, when aetiological factors are introduced into a population, the first birth cohorts will inevitably consist of elderly patients (Fig. 35). ${ }^{1}$

\section{Sex-specific incidence rates}

The trend in sex ratio by age (Fig. 17), with a peak in the age group 30-49 years, may be related to increased risk of exposure in adult males. In addition to risk of exposure in the household, adult males bear a higher risk than females of being infected in the community due to work outside the household. The trend in sex ratio by time (Fig. 15), with an increase during the observation period, is consistent with a higher relative importance of infection in the community towards the end of the observation period. The trend in sex ratio by average incidence rate (Table 38 , Table 39), with a low ratio in highrate areas and vice versa, is also consistent with the concept.

\section{Type index}

The trend in type index by age and sex (Fig. 27), with a relatively low-type index in the age group 0-9 years and a higher index in the group 10-14 years, and with no difference between males and females, is apparently related to children infected during the first years af ter birth, indicating a longer incubation

${ }^{1}$ The figure shows courses of life, i.e. diagonals, between 0 and 85 years for cohorts born between 1815 and 1915. In this simplified example, aetiological factors influenced the population from 1870 to 1930 . With a mean incubation period of 10 years, persons might be taken ill from before 1880 to after 1940. The oldest cohort, born 1816-20, would be affected only over the age of 60 years, while the cohort born 1911-15 would be affected only under the age of 30 . 
period in type 1 cases. A high-type index in males 20-39 years (and in females 20-24 years), and a lower-type index in females than in males in the age group 25-59 years, may be related to the fact that vocational contacts, primarily of males, outside the household were more close and prolonged than nonvocational contacts, in particular because of the fisheries during which many men, and especially men from the high frequency regions, lived together in small shanties for longer periods. These contacts might involve a dose of exposure even as high as in a common household. The lower index in the age group $50+$ in both males and females, refers to the patients who, though relatively few, were after all taken ill at a late age, probably infected with a low dose and a short duration in the community, but not due to vocational contacts.

The increase in type index in all age groups towards the end of the observation period in males (Fig. 29) might be caused by the fact that when incidence rates are rapidly declining, patients with long incubation periods (and accordingly more malignant types of the disease), will be more and more frequent in all age groups. The increasing sex ratio in the age group $50+$ towards the end of the observation period (Fig. 18) might be related to the increasing relative importance of vocational contacts. At the end of the observation period, males infected through such contacts would have a higher age at onset due to the longer incubation period.

However, the opposite trend, involving a decrease in type index towards the end of the observation period, caused by an increasing relative importance of infection in the community, might counteract the effect of prolonged incubation periods. This might relate to the trend in type index observed in females, with a decrease in type index towards the end of the observation period particularly in the age groups over 30 years (Fig. 29). However, why males and females were affected in different ways is not obvious. Apparently, there is no indication that female contacts with the community at large increased considerably towards the end of the observation period. The influence of other factors related to a decreasing susceptibility, cannot be excluded.

\section{Bias in the registration}

Possibilities of bias in the registration have been discussed previously (vide 2.3.4.). However, on the basis of the results, the problem may be further enlarged upon. It seems reasonable to suppose that in areas and periods in which the disease occurred infrequently, the risk of under-registration could not be neglected. Thus a high mean age at onset and a high sex ratio registered in areas where average incidence rates were low, and registered towards the end of the observation period, might be caused by under-registration, since women in general and men below the age of 20 were generally less known to the public and might hide away in the home. (A high age at onset might also be caused by delay in the registration work under the same conditions, though this possibility 
has already been disproved). However, this was not consistent with the finding of a low-type index in areas with low average incidence rates; i.e. in these areas the less conspicuous type of leprosy was more frequent. Thus, there appears to be no reason to believe that the other trends are due to biased registration. Furthermore, the peculiar finding of a lower-type index in females towards the end of the observation period cannot be explained as due to such a bias in registration.

\section{Predictions of incidence rates}

The associations demonstrated to exist in the present material between the measures: sex ratio, mean age at onset and type index of patients registered in a period on the one hand, and incidence rates in the same period on the other, proved to be sufficiently strong to form a basis for prediction, with reasonable validity, of incidence rates and even time trend in incidence rates. The associations of mean age at onset with the dependent variables, were far higher than the associations of sex ratio and type index. A high association between an increasing mean age at onset and a decreasing incidence rate will most likely occur irrespective of time and place. A similar trend has been recognized in other countries (Kim, 1979; Saikawa, 1975; Kyaw Lwin and Zuiderhock, 1975), and also in other chronic infectious diseases such as tuberculosis (Backer, 1961). The trend is mainly due to the increasing relative predominance of long incubation periods; irrespective of other conditions.

However, for the other independent variables, different values of the coefficients will probably be found in other materials, possibly due to different epidemiological conditions; (Kinnear Brown, 1959) e.g. socio-economic or environmental patterns.

\section{Features in other countries}

To find, through the interpretation of epidemiological data, general patterns in the distribution of leprosy patients according to sex, age and type in other countries, represents a difficult task. In part, different methodological approaches make comparisons even of trends impossible (Meade, 1971), in part different epidemiological conditions overshadow common features.

In the Philippines, a country with most reliable epidemiological data on leprosy, Doull (1962) has reported trends which appear to be similar to those discussed in the present study. Attack rates were low in young and old age groups, however, highest rates being found at somewhat earlier age than in Norway, viz. 10-14 years against 15-29 years in Norway. Male and female prevalence rates (Doull et al., 1936) by age depicted a trend similar to that found in Norway, with no male excess in the young age group, and a male excess particularly in the age group 30-49 years. In the Philippines, incidence rates of tuberculoid leprosy exceeded rates of lepromatous leprosy in all age 
groups; accordingly, type index was far lower than in Norway. The lower-type index with shorter incubation periods, was probably one reason why mean age at onset was lower in the Philippines. Type index had a peak in the age group 15-29 years, as in Norway. Furthermore, it was demonstrated that patients of exposed households had a lower mean age at onset than patients of households which were not known to have been exposed.

Similar trends were found in studies in Burma (Bechelli et al., 1973), and in the New Hebrides (Ratard and Bravo, 1978). In addition, prevalence data in Burma and incidence data in the New Hebrides, together with prevalence data (Rao et al., 1972a) and clinical data (Sehgal et al., 1977) in India, demonstrated that type index in adult males, to a varying extent, exceeded type index in adult females.

In Nigeria, Davey (1957) made an observation of particular interest. In a community where females did not lead secluded lives, a sex ratio near 100 was found, indicating a relationship between sociological features and risk of exposure. A similar finding was reported by Browne (1965).

Apparently, a statement by Newell (1966) has made a great impact on subsequent research. Prevalence rates of lepromatous leprosy, Newell asserted, are never observed to exceed 5-10 per 1,000. On this basis, the causation of lepromatous leprosy was related to a host determined characteristic possessed by a fixed proportion of all people everywhere. The basis of this inference is hardly compatible with the present findings. In several health districts in Norway with high morbidity rates, type-1 prevalence rates exceeded 10 per 1,000. Similar observations were made by Bechelli and Martinez Dominguez (1972).

As demonstrated by Godal (1978a), Newell's statement was based on a heterogeneous epidemiological situation in which differences in incubation period between lepromatous and non-lepromatous cases apparently were not taken into consideration. Obviously, susceptibility of the host, in addition to dose and duration of exposure, may influence the clinical course of the disease and the differentiation into type. However, that this host determined characteristic should be possessed by a fixed proportion of the population everywhere, seems unlikely. On the contrary, the distribution of possible additional factors influencing susceptibility, e.g. malnutrition, most probably involves considerable geographical differences, consistent with the great differences observed in the occurrence of leprosy between different regions.

Thus, most of the findings in Norway as elsewhere, seem to be consistent with the concept of differences relating to infection in the household and infection in the community, implying a higher total incidence and type index when dose and duration of exposure is high and a longer incubation period in lepromatous cases. Thus, most of the differences observed in the distribution of cases according to sex, age and type seem to be caused by different risks of exposure and not necessarily by inherent differences in susceptibility (see also Kinnear Brown, 1959; Doull, 1962; Davey, 1957; Newell, 1966; among others). 
Compared with other countries, sex ratio was relatively low and type index was high in Norway. The proportion of type 1 cases (the lepromatous index conventionally calculated) registered in Norway during the observation period amounted to $53.8 \%$, and number of male cases per 100 female cases was 139.4 . This is supposed to be due to the assumption that the relative importance of infection in the household was greater in Norway than in most other countries, in part since traffic in Norway has always been hindered by a rugged landscape, in part since density of the population was low, and in part since the scattered population, even at the local level, did not live clustered in villages as in other parts of the world; the farm houses were separated by relatively long distances.

\section{Movements in the diagnostic spectrum}

Movements in the diagnostic spectrum were consistent with trends which are considered general principles of such movements (Godal, 1978a). Type 2 patients moved far more frequently than patients belonging to the two polar types. Furthermore, these type 2 patients tended to move towards the lepromatous end of the spectrum more than towards the tuberculoid end; $62 \cdot 1 \%$ and $37.9 \%$ respectively. However, the trend in movements towards type 1 did not exceed the relative proportion of all type-1 cases compared with all type- 3 cases. Movements from the polar types occurred almost as frequently in type 1 as in type 3; however, movements towards the intermediate type 2 were far more frequent than movements towards the other polar type.

A high frequency of movements from type 2 might, in accordance with the general principles, be due to a more unstable character of the intermediate type. However, the trend might also be caused by the instructions of the Chief Medical Officer to avoid the classification of a case as type 2 (vide 2.5.3.). However, such an interpretation seems less likely because of the extensive use of type 2 also in the description of movements in the diagnostic spectrum.

\subsubsection{OCCURRENCE IN FAMILIES}

Incidence rates of persons living in households together with an index case are higher than rates of persons not known to be so exposed. Without doubt this observation is due to differences in dose and duration of exposure. In addition, differences with respect to susceptibility may play an important part. Susceptibility may relate to environmental or genetic factors. However, people living together in a household usually share a common background of genetic and environmental factors, which has represented a major problem to the epidemiological approach of studying susceptibility in families. The avoidance of this problem was attempted in the present study. 


\section{Present findings}

In all categories of families in the present study except marriages, the distribution of cases with respect to type differed from expected frequencies, and the distances between the members of each family were shorter than expected, implying concordance. Furthermore, type index increased with number of patients per family. However, these findings might be due to environmental or genetic additional factors.

On the other hand, in sibships in which age at onset of one or more patients exceeded 30 years, type index did not increase with number of patients per sibship; and more importantly, distribution of cases with respect to type did not differ from expected frequencies (Table 34). In general, it may be assumed that old sibships in many ways are mutually more different than young sibships, and possible differences present in old sibships, but not in young ones, are considered to be due to environmental rather than genetic factors. Thus, a high degree of concordance with respect to type, found in young sibships and not in old ones, indicates an effect of environmental factors. Obviously, however, it should be stated that this finding does not preclude other effects of possible genetic factors.

The finding of a higher type index in children of sick mothers than in children of sick fathers (Table 35) is consistent with a higher dose of exposure when mother was ill. In such cases it appeared that children contracted type 1 irrespective of the type of disease in the mother, implying a considerable infectiousness also of non-lepromatous cases. However, a father with type 1 apparently represented a dose of infection sufficient to produce type 1 cases.

Degree of concordance within sibships consisting of sick children and between sick children and their sick parent was higher in families where father was affected compared with families in which mother was affected. Presumably sick mothers, irrespective of their own type of leprosy and also of the relative susceptibility of their children, would tend to propagate type 1 to their children. The result would be that sibships with a high susceptibility would react homogeneously and develop type 1 , while sibships with a low susceptibility would react heterogeneously, and degree of concordance, mutually and with mother, would be low if present at all. This interpretation is consistent with the concept that susceptibility is not only dependent on dose and duration of exposure.

Number of affected children per marriage was higher for affected mothers than for affected fathers, and in particular for parents affected with type 1 . Without doubt, this might be caused by a higher dose of infection represented by sick mothers. However, probably total number of children (patients and non-patients) was dependent on whether father or mother had leprosy. Childless marriages in Norway were more frequent if the husband was affected and particularly with type 1, than if the wife was affected (Lie, 1911). Apparently, male fertility is severely impaired in untreated leprosy (Davey and Schenck, 
1964). Thus, total number of children in families with a sick father might have been lower. This is also consistent with the finding that fathers with a higher dose of exposure, represented by fathers affected by type 1, did not have more sick children than fathers affected by type 2 and type 3 .

In pairs of spouses, type index was higher in the second-cases than in the first-cases. Three causes seem obvious. First, if a person already affected with leprosy was to marry a healthy person, the patient most probably was affected with type 3, the most benign form. Secondly, if two spouses were infected at the same time, and one spouse was taken ill a considerable time before the other, the second-case would tend to be of type 1 and the first-case would tend to be of either type 2 or type 3 . Thirdly, a spouse infected by the other spouse, would have a relatively high dose and long duration of exposure and would, accordingly, tend to develop type 1 .

On the other hand, the finding of a low type index in the first-cases suggests that type- 3 cases were also infectious. If not, type index in the first-cases would have been far higher than type index in the second-cases. Nothing beyond speculation may be offered to explain the peculiar high type index in spouses with contemporary onset of leprosy.

Thus it may be concluded that type index in families is influenced according to the hypothesis of dose and duration of exposure. Furthermore, dependence within families with respect to type of leprosy, i.e. concordance, seems to be related to susceptibility influenced by an environmental factor of uncertain duration, apparently not present in sibships with age at onset higher than 30 years and in spouses. Probably, individuals in the first group had lived apart from each other too long, and individuals in the latter had lived together too short a time to be influenced by this factor. Obviously, the hypothesis of an influence of genetic factors is not disproved by the present findings; however, such a hypothesis is not supported either.

\section{Other studies}

Major methodological problems are involved in the studies of the occurrence of leprosy in families (Lechat, 1965). Up to the present time the part played by genetic factors in the aetiology of leprosy appears obscure (Godal, 1978a; White et al., 1978). Conclusions based on studies of the major histocompatibility complex seem inconsistent (Rea et al., 1976; de Vries et al., 1976; Fine et al., 1978). The difference in degree of concordance observed between monozygous twins and dizygous twins (Chakravartti and Vogel, 1973) does not appear significant. Associations demonstrated to exist between chronic subclinical hepatitis and lepromatous leprosy have been supposed to be due to a genetic factor, since chronic subclinical hepatitis appears to be related to the socalled Au-gene. (Blumberg et al., 1970). However, conclusive evidence to support the hypothesis is lacking. On the contrary, in a study in Uganda, comprising more than 20,000 children, no evidence was found that the incidence of 
leprosy varied according to a child's genetic relationship to a leprosy patient, once allowance had been made for the degree of physical contact (White et al., 1978).

Secondary attack rates among spouses are found to be under $10 \%$ in most studies (Mohammed Ali, 1965; Newell, 1966). Sand (1910) found a rate of $3.3 \%$ among patients at a leprosy hospital in North Norway, and Lie (1911) found a rate of 5\% among hospital patients in West Norway. Observations of the occurrence of leprosy among spouses, claimed to be influenced by genetic factors (Mohammed Ali, 1965), may just as well be related to environmental factors.

Apparently no findings in the abundant literature preclude the suggestions that the occurrence of leprosy in families is influenced in part by the high dose and duration of exposure, and in part by a susceptibility related to environmental factors.

\subsection{Concluding remarks}

Risk of exposure, apparently, plays an important part in the distribution of leprosy. Higher incidence rates in adult males than in adult females, and higher incidence rates in young adults than in elderly people and children, are attributable to differences in risk of exposure. Accordingly, the supposition of an inherent susceptibility in special age- and sex-groups seems unnecessary to explain differences in age- and sex-specific incidence rates. It should be emphasized that not only children but also adults and elderly people may be infected and taken ill if exposed.

The geographical distribution of leprosy in Norway, at regional level, seemed to be related to patterns of communication. Moreover, differences between the regions in air humidity, an important condition for growth of mycobacteria in the environment, seemed to correspond with differences between regions in the occurrence of leprosy. Also at local farm level, the distribution appeared to be related to conditions for growth of mycobacteria. Several species of cultivable mycobacteria, but also unidentified non-cultivable mycobacteria, were found in local bogs in a formerly topprevalence health district. Furthermore, the distribution of leprosy within this district was associated with local conditions for growth of mycobacteria in the sphagnum bog vegetation. However, it is most important to state that validation of this hypothesis, and clarification of its theoretical and practical implications, should be based on further studies in areas where leprosy is prevalent today.

At a local level, the distribution of leprosy was also associated with malnutrition, while overcrowding apparently represented no significant additional factor.

Also in families, the occurrence of leprosy seemed to be related to dose and 
duration of exposure, causing a high-type index in families with several patients. Concordance with respect to type might be explained as being due to environmental factors influencing susceptibility. The findings did not imply the influence of genetic factors.

The rapid decline in incidence rates over 70 years seemed hardly attributable to genetic mechanisms. It appeared that physical isolation of infectious patients in leprosy hospitals in high prevalence situations represented an important cause of the decline. Probably isolation was particularly efficient when the relative importance of infection in the household was high; i.e. when prevalence rates were high. When the relative importance of infection in the community at large was high, i.e. when prevalence rates were low, isolation was probably less efficient. Improved nutritional conditions and selective emigration of high-risk groups represented other important causes of the decline.

Even though isolation obviously is not a relevant control measure today, the rapid decline together with the considerable geographical variation in incidence rates, also observed in other countries, form in part the basis of future leprosy control. In large areas it may be assumed that improved nutrition will most probably reduce susceptibility for a considerable proportion of the population. At the present stage, no more than speculations can be offered about practical implications of the finding of non-cultivable mycobacteria outside the human body. However, the importance of further research to assess the relevance of these findings to the epidemiology of leprosy and to leprosy control seems evident. The development of an efficient vaccine will, if feasible (Godal, 1978b), no doubt offer an important control measure (Lechat, 1978). However, in a comprehensive control programme, a possible vaccine should be applied, taking all relevant aspects of primary prevention into consideration.

Irrespective of the approach used in primary prevention, leprosy control should be based on reliable information as to level of morbidity rates and time trends, i.e. preferably incidence rates. However, in many areas, incidence rates are still difficult to obtain, and to the extent that associations in such areas exist between incidence rates and trends in incidence on one hand, and characteristics of the patients registered on the other, indices, used as substitutes for incidence rates, may be employed. 



\section{References}

Aycock WL (1940) Familial susceptibility as a factor in the propagation of leprosy in North America. Int J Leprosy, 8, 137.

Backer J (1961) Trend of mortality and causes of death in Norway 1856-1955. Central Bureau of Statistics of Norway, Oslo.

Bechelli LM, Martinez Dominguez V (1972) Further information on the leprosy problem in the world. Bull Wld Hlth Org, 46, 523.

Bechelli LM, Garbajosa PG, Gyi Mg Mg, Vemura K, Sundaresan T, Tamondong C, Martinez Dominguez V, Walter J (1973) Some epidemiological data on leprosy collected in a mass survey in Burma. Bull Wld Hlth Org, 48, 335.

Bidenkap JL (1858) Indberetning til den af det Medicinske Selskab i Anledning af Spedalskheden nedsatte Committee. Norsk Mag f Laegev, 12, 398-417, 465-81.

Bidenkap JL (1860) Om Spedalskheden som endemisk Sygdom i Norge. Norsk Mag $f$ Laegev, 14, 535-81, 713-79, 809-52, 889-97.

Bjerkedal T, Irgens LM (1973) Epidemiology of leprosy in Norway: Changes in age distribution of new cases during a period of decreasing incidence. Int J Leprosy, 41, 597.

Blumberg BS, Melartin L, Guinto R, Lechat MF (1970) Lepromatous leprosy and Australia antigen with comments on the genetics of leprosy, J Chron Dis, 23, 507.

BMDP (1975) Biomedical Computer Programs, Dixon WJ, ed. University of California Press, Berkeley, Los Angeles, London.

Boeck CW (1871) Spedalskheden i de forenede Stater i Nord-Amerika. Nord Med Arkiv, 3, 1. Browne SG (1965) The age of onset of leprosy. Int J Leprosy, 33, 267.

Chakravartti MR, Vogel F (1973) A twin study on leprosy. Top hum Genet, 1, 1.

Chandra RK (1974) Rosette forming $\mathrm{T}$ lymphocytes and cell-mediated immunity in malnutrition. $\mathrm{Br}$ med $J$, iii, 608 .

Chaussinand R (1948) Tuberculose et lèpre, maladies antagoniques. Eviction de la lèpre par la tuberculose. Int J Leprosy, 16, 431 .

Cochrane RG, Davey TF, eds. (1964) Leprosy in theory and practice. Bristol: John Wright and Sons Ltd.

Crawford CL (1973) Hansen's classification of leprosy. Int J Leprosy, 41, 584.

Danielssen DC, Boeck CW (1847) Om Spedalskhed. Christiania: Christian Gr $\varnothing$ ndahl.

Davey TF, Schenck RR (1964) The endocrines in leprosy. In Cochrane RG, Davey TF, eds. Leprosy in theory and practice. Bristol: John Wright and Sons Ltd, 190.

Davey TF (1957) Decline of leprosy in a group of Nigerian villages between 1941 and 1956. Int J Leprosy, 25, 329.

Davey TF (1975) Common features in rapidly declining leprosy epidemics. Lepr Rev, 46, 9.

Davey TF (1978) A day in the life of Yeeranna - A cautionary tale. Lepr Rev, 49, 269.

Desikan KV, Sreevatsa (1978) Viability of Mycobacterium leprae outside the human body. Abstracts, XI Int Lepr Congr, 51 .

Doull JA, Rodriguez JN, Guinto R, Plantilla FC (1936) A field study of leprosy in Cebu. Int $J$ Leprosy, 4, 141. 
Doull JA, Guinto RS, Bancroft H, Rodriguez JN (1947) Historical inquiry as a method of estimating the trend of leprosy. Int J Leprosy, 15, 369.

Doull JA (1962) The epidemiology of leprosy. Present status and problems. Int J Leprosy, $30,48$.

Feldman RA (1973) Leprosy surveillance in United States 1949-1970. Int J Leprosy, 41, 598.

Feldman RA, Sturdivant M (1975) Leprosy in Lousiana, 1855-1970. An epidemiologic study of long-term trends, Am J Epidemiol, 102, 303.

Fine PEM, Wolf E, Pritchard J, Watson B, Bradley DJ, Festenstein H, Chacko CJG (1978) On the genetics of susceptibility to leprosy. Abstracts, XI Int Lepr Congr, 5.

Godal T, Negassi K (1973) Subclinical infection in leprosy. Br med J, iii, 557.

Godal T, Myrvang B, Stanford JL, Samuel DR (1974) Recent advances in the immunology of leprosy with special reference to new approaches in immunoprophylaxis. Bull Inst Pasteur, 72, 273.

Godal T (1978a) Immunological aspects of leprosy - present status. Prog Allergy, 25, 211.

Godal T (1978b) Is immunoprophylaxis in leprosy feasible? Lepr Rev, 49, 305.

Guinto RS, Rodriguez JN (1941) A field study of leprosy in Talisay, Cebu, Philippines. Int $J$ Leprosy, 9, 149.

Guinto RS, Rodriguez JN, Doull JA (1954) The trend of leprosy in Cordova and Talisay Cebu Province, Philippines. Int J Leprosy, 22, 409.

Hamilton MA (1979) Choosing the parameter for a $2 \times 2$ table or a $2 \times 2 \times 2$ table analysis. Am J Epidemiol, 109, 362.

Hansen GHA (1874) Unders $\phi$ gelser angaaende Spedalshedens Aarsager. Norsk Mag f Laegev, 4, suppl. 1-88.

Hansen GHA, Looft C (1895) Leprosy in its clinical and pathological aspects. Bristol: John Wright and Co.

Hilpert G (1972) Die Lepraendemie in der Welt und ihre Bekämpfung. Hamburg: Fachbereich Medizin der Universität Hamburg.

Historical Statistics (1968) Central Bureau of Statistics, Oslo.

Hjort JJ (1871) Om Spedalskheden i Norge. Christiania: P F Steensballe.

Holmboe JA (1865) Den spedalske Sygdom blandt de Norske i Amerika. Norsk Mag f Laegev, $19,153$.

Hutchinson J (1906) On leprosy and fish-eating. London: Archibald Constable \& Co.

Irgens LM (1973) Leprosy in Norway: An Interplay of Research and Public Health Work. Int $J$ Leprosy, 41, 189.

Irgens LM (1973a) Epidemiology of leprosy in Norway: The control of a public health problem Int J Leprosy, 41, 597.

Irgens LM, Bjerkedal T (1973) Epidemiology of Leprosy in Norway: The History of the National Leprosy Registry of Norway from 1856 until today. Int J Epidemiol, 2, 81.

Irgens LM, Vaula D, Skjærven R (1978) The use of information in addition to incidence rates in the evaluation of a vaccination trial against leprosy. Abstracts, XI Int Lepr Congr, 3 .

Kazda J, Müller K, Irgens LM (1979) Cultivable mycobacteria in sphagnum vegetation of moors in south Sweden and coastal Norway. Acta path microbiol scand, Sect. B, 87, 97.

Kazda J (1979) Principles of the ecology of mycobacteria, in Stanford J, ed. The Mycobacterial World, the Biology of Mycobacteria. London: Academic Press 1979 (in press).

Kim DI (1979) The current situation of leprosy in Korea. Report by Korean Leprosy Institute, Seoul.

Kinnear Brown JA (1959) Factors influencing the transmission of leprosy. Int J Leprosy, 27, 250.

Kloster R (1940) Kulturgeografiske registreringer i Fjordane 1940. Unprinted notes at 
Historisk museum, University of Bergen, revised by JH Munksgaard.

Kyaw Lwin, Zuiderhoek B (1975) Case detection rate for central Burma (1962-1972). Int J Leprosy, 43, 125.

Lechat MF (1965) Methodology of genetic study in the epidemiology of leprosy. Int $J$ Leprosy, 33, 744.

Lechat MF (1971) An epidemiometric approach for planning and evaluating leprosy control activities. Int J Leprosy, 39, 603.

Lechat MF (1973) L'Epidémiologie de la lèpre au cours des 100 dernières années. Int J Leprosy, 41, 298.

Lechat MF, Misson.JY, Vellut CM, Misson CB, Bouckaert A (1974) Un modele épidémiométrique de la lèpre. Bull Wld Hlth Org, 51, 361.

Lechat MF, Misson CB, Bouckaert A, Vellut C (1977) An epidemiometric model of leprosy: a computer simultation of various control methods with increasing coverage. Int $J$ Leprosy, 45, 1.

Leiker DL (1960) Epidemiological and immunological surveys in Netherlands New Guinea. Lepr Rev, 31, 241.

Leiker DL (1977) On the mode of transmission of Mycobacterium leprae. Lepr Rev, 48, 9.

Lexis W (1875) Einleitung in die Theorie des Bevölkerungsstatistik. Strassburg: Karl J Trübner.

Lie HP (1911) Statistisches über lepra. Arch F Derm u Syph, 110, 473.

Lie HP (1912) Über die Flecken der Lepra maculoanaesthetica. Arch F Derm u Syph, 113, 677.

Lie HP (1923) Litt om forskjellige former for spedalskhet særlig lepra tuberculoides. Med Revue, 10, 143.

Lie H P (1927) Tuberculosis and leprosy. Acta derm - venereol, 8, 21.

Lie HP (1929) Why is leprosy decreasing in Norway? Trans of the Royal Soc of Trop Med and Hyg, 22, 357.

Lie H P (1938) Norwegian lepers in the United States. Int J Leprosy, 6, 351.

Looft C (1891) Bidrag til kundskaben om lepra anaestheticas aetiologi og anatomi. Festskrift til D.C. Danielssens 50-års embedsjubileum, Bergen.

Matrikkel (1890) Fortegnelse over matrikulerede Eiendomme og dere skyld den 30te September 1890. Kristiania 1903-1908.

Meade TW (1971) Epidemiology and leprosy control. Lepr Rev, 42, 14.

Meade TW (1977) How effective is the treatment of leprosy? Lepr Rev, 48, 3.

Melsom RS (1948) A survey of leprosy cases. Acta derm. - venereol, 28, 256.

Mohammed Ali P (1965) A study of conjugal leprosy. Int J Leprosy, 33, 223.

Mohn H (1921) Atlas de Climat de Norvège. Kristiania: Gr $\phi$ ndahl and Sons.

Monge RJ, Castro ER (1968) (The Epidemiology of leprosy in Costa Rica. Acta Med Costarrie, 1, 1967, 59.) Abstract in Int J Leprosy, 36, 372.

Newell K W (1966) An epidemiologist's view of leprosy. Bull Wld Hlth Org, 34, 827.

NOS (1835) Statistiske Tabeller for Kongeriget Norge, 1. Rekke, Christiania, 1838.

NOS (1845) Statistiske Tabeller for Kongeriget Norge, 8. Rekke, Christiania, 1847.

NOS (1855) Statistiske Tabeller for Kongeriget Norge, 16. Rekke, Christiania, 1857.

NOS (1865) Resultaterne af Folketællingen i Norge i Januar 1866. C. No. 1. Christiania 1868.

NOS (1875) Folketællingen i Norge i Januar 1876. C. No. 1. Christiania 1878.

NOS (1890) Folketællingen i Kongeriget Norge 1. Januar 1891, 3. Rekke, No. 202, Kristiania 1894.

NOS (1900) Folketællingen i Kongeriget Norge 3. December 1900, 4. Rekke, No. 52, Kristiania 1902.

NOS (1910) Folketællingen i Norge 1. December 1910, 5. Rekke, No. 170, Kristiania 1912. 
NOS (1920) Folketællingen i Norge 1. December 1920, 7 Rekke, No. 39, Kristiania 1922.

NOS (1921) Den norske oversjфiske utvandring. Norges offisielle statistikk. VII. 25. Kristiania.

Rao PSS, Karat ABA, Kaliaperumal VG, Karat S (1972a) Prevalence of leprosy in Gudiyatham Taluk, South India, Part II. Geographical variations. Int J Leprosy, 40, 164.

Rao PSS, Karat ABA, Kaliaperumal VG, Karat S (1972b) Incidence of leprosy in Gudiyatham Taluk, South India. Indian J Med Res, 60, 97.

Rao PSS, Karat ABA, Kaliaperumal VG, Karat S (1975) Transmission of leprosy within households. Int $J$ Leprosy, 43, 45.

Rasi E, Castellazi Z, Garcia L, Quevedo L, Convit J (1975) Evaluation of 'chemical isolation' in 1,168 leprosy patients' homes. Int J Leprosy, 43, 101.

Ratard RC, Bravo LL (1978) The Epidemiology of leprosy in the New Hebrides. Lepr Rev, 49,31 .

Rea TH, Levan NE, Terasaki PI (1976) Histocompatibility antigens in patients with leprosy. J Infect Dis, 134, 615.

Ridley DS, Jopling WH (1966) Classification of leprosy according to immunity. A five-group system. Int J Leprosy, 34, 255.

Russell DA (1968) BCG and prophylaxis - the Karimui trial. Int J Leprosy, 36, 638.

Saikaiwa K (1975) An epidemiologic study of leprosy in the Ryukyu Islands. II. The geographical status (Japanese). Summary in Int J Leprosy 1977, 45, 316.

Sand A (1910) Geschiet die Ansteckung der Lepra durch unmittelbare Übertragung. Mitteilungen und Verhandlungen. II. Leprakonferenz, Bergen, 3, 39.

Sartwell PE (1950) The distribution of incubation periods of infectious disease. Am J Hyg, $51,310$.

Sehgal VN, Rege VL, Singh KP (1977) The age of onset of leprosy. Int J Leprosy, 45, 52.

Shield MJ, Rees RJW, Stanford JL (1977) Results of skin testing with A 6 (Mycobacterium leprae) in Burma 1975. Second report to IMMLEP.

Shield MJ, Stanford JL (1977) A synopsis of the possible explanation of the epidemiological situation in Burma, with reference to leprosy, based on the most recent analysis of the data available. Report to IMMLEP.

Skinsnes OK (1975) Immuno-epidemiology of leprosy. Int J Leprosy, 43, 145.

Skinsnes OK (1976a) Effect of malnutrition on leprosy. Int J Leprosy, 44, 374.

Skinsnes OK (1976b) 'Leprosy' in wild armadillos. Int J Leprosy, 44, 376.

Spickett SG (1962a) Genetics and the epidemiology of leprosy. I. The incidence of leprosy. Lepr Rev, 33, 76.

Spickett SG (1962b). Genetics and the epidemiology of leprosy. II. The form of leprosy. Lepr Rev, 33, 173.

SPSS (1975) Statistical package for the social sciences, (Nie NH, Hadlai Hull C, Jenkins JG, Steinbrenner K, Bent DH), 2nd ed. New York: McGraw-Hill.

Sundt E (1869) Om Renlighedsstellet i Norge. Christiania: J. Chr. Abelsted.

Suresh K, Mani RS, Rao AK, Rao DM (1969) Results after five years of intensive leprosy control work in a high endemic area. Lepr Rev, 40, 211.

Vellut C (1969) Leprosy control work at Polambakkam and its critical appraisal. Lepr Rev, 40, 203.

de Vries RRP, Lai A, Fat RFM, Nijenhuis LE, van Rood JJ (1976) HLA-linked genetic control of host response to Mycobacterium lepra. Lancet, ii, 1328.

Walsh GP, Storrs EE, Burchfield HP, Cottrell EH, Vidrine MF, Binford CH (1975) Leprosylike disease occurring naturally in armadillos. J Reticuloendothelial Soc, 18, 347.

Washburn WL (1950) Leprosy among Scandinavian settlers in the Upper Mississippi Valley, 1864-1932. Bull Hist Med, 24, 123.

White SJ, Stone MM, Howland C (1978) Genetic factors in leprosy: a study of children in Uganda. J Hygiene, 80, 205. 


\title{
Leprosy Review Index
}

\author{
VOLUME 51 (1980)
}

PAGE

Abstracts

Action Medeor; Deutsches Medikamenten

Advance notice of seminars, international meetings and conferences on leprosy. Letter to the Editor. J. T. CASSIDY

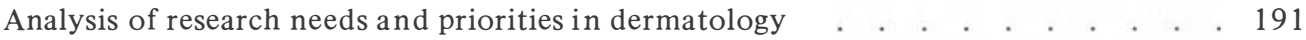

ANDERSON, R., GATNER, E. M.S., IMKAMP, F. M. J.H. and KOK, S. H., In vivo effects of propranolol on some cellular and humoral immune functions in a group of patients with lepromatous leprosy .

ANDRE, P. SAINT, The Marchoux Institute . . . . . . . . . . . . . . 35

-, see BAQUILLON, G. . . . . . . . . . . . . . . . . . . . . . . . 315

ANTIN, U. S., see SMITH, W. C. S. . . . . . . . . . . . . . . . . . 155

ACHAREKAR, M. Y., see GANAPATI, R. . . . . . . . . . . . . . . . . 325

Assaying dapsone in mouse diets. G. A. ElLAR D. . . . . . . . . . . . . . . 321

Auxiliaries in primary health care.

BAQUillon, G., FERRACCI, C., ANDRE, P. SAINT and PATTYN, S. R., Dapsoneresistant leprosy in a population of Bamako (Mali) . . . . . . . . . . 315

Belgium honours Dr Stanley Browne . . . . . . . . . . . . . . . . . 256

BERGEYCK, E. DE., JANSSENS, P. G. and MUYNCK, D. DE., Radiological abnormalities of the ileum associated with the use of clofazimine (Lamprene; B663) in the treatment of skin ulceration due to Mycobacterium ulcerans . . . . . . . .

BHARADWAJ, V. P. SRITHARAN, V., VENKATESAN, K., RAMU, G. and DESIKAN, K. V., Effect of DDS therapy on blood pyruvate and lactate levels in leprosy patients

Bombay Leprosy Project . . . . . . . . . . . . . . . . . . . . . 83

Book Reviews . . . . . . . . . . . . . . . . . . . . . 99, 265, 363

Case-finding and case holding in Malawi. Letter to the Editor. N. M. CHITIMBA . 91

CHACKO, C. J. G., see THOMAS. J. . . . . . . . . . . . . . . . . . . . . 329

'Comment Combattre la Resistance a la Dapsone?' . . . . . . . . . . . . . . . . 64

Community participation in leprosy control and other health programmes: an anthropologist's viewpoint . . . . . . . . . . . . . . . . . . . . . . . 245

Courses of interest to scientific and technical staff in the NHS(UK) . . . . . . . . 192

Damien-Dutton Award . . . . . . . . . . . . . . . . . . . . . . . 83

Dapsone and nerve damage. Letter to the Editor. GRACE WARREN $\quad . \quad$. $\quad . \quad . \quad 94$ 
Dapsone resistant leprosy in a population of Bamako (Mali) G. BAQUILLON, C.

FERRACCI, P. SAINT ANDRE and S. R. PATTYN . . . . . . . . . . 315

Dapsone resistant leprosy in Ethiopia. Letter to the Editor. TITIA WARNDORF . . 261

Dapsone resistant leprosy in Ethiopia. Reply. Letter to the Editor. J. M. H. PEARSON,

G.S. HAILE, R. St C. BARNETSON and R. J. W. REES . . . . . . . .

Demonstration of antibodies against Mycobacterium leprae both in immunoglobulin $\mathrm{G}$ and $\mathrm{M}$ in sera from pregnant and non-pregnant lepromatous leprosy patients,

R. MELSOM and M. E. DUNCAN .

DESIK AN, K. V., see BHARADWAJ, V. P. . . . . . . . . . . . . . . . . . . . 237

-, see RAMU, G. . . . . . . . . . . . . . . . . . . . . . . 207

Disability in leprosy: a relevant measurement of progress in leprosy control. W. C. S.

SMITH, U. S. ANTIN and A. R. PATOLE . . . . . . . . . . . . 155

Does clofazimine have any value in the management of reversal reaction? Letter to the

Editor. W. F. ROSS .

Does clofazimine have any value in the management of reversal reaction? Reply. Letter

to the Editor. F. M. J. H. IMKAMP. . . . . . . . . . . . . . . . 360

DUNCAN, M. E., see MELSOM, R. . . . . . . . . . . . . . . . . . 125

- , see MELSOM, R.

EBONG, OMOTOAYO O. and NWUNDE, N., Some plants used in the treatment of leprosy in Africa.

Editorials:

Combined treatment for lepromatous leprosy, G. A. ELLARD

Guide to leprosy control; WHO/LEP/79.9, A. C. McDOUGALL . . . . . . . 1

Macrophage stimulation and activity in lepromatous leprosy, D. S. RIDLEY . . 111

Educational Aids, List of, 1979, Armed Forces Institute of Pathology, Washington, DC, USA

Educator's International Guide to Free and Low Cost Health Audio-Visual Aids . . .

Effect of DDS therapy on blood pyruvate and lactate levels in leprosy patients. V. P.

BHARADWAJ, V. SRITHARAN, K. VENKATESAN, G. RAMU and K. V.

DESIKAN . . . . . . . . . . . . . . . . . . . . . . . . 237

ELLARD, G. A., Assaying dapsone in mouse diets . . . . . . . . . . . . . 321

-, Editorial. Combined treatment for lepromatous leprosy . . . . . . . . . . . . . 199

-, Profile of urinary dapsone/creatinine ratios after oral dosage with dapsone . . . 229

Excerpta Medica. Leprosy and related subjects . . . . . . . . . . . . . 86, 259

Failure to detect $O$-diphenoloxidase in cultivable mycobacteria obtained from feral armadillos. K. PRABHAKARAN, E. B. HARRIS and W. F. KIRCHHEIMER . . 341

FERRACCI, C., see BAQUILLON, G. . . . . . . . . . . . . . . . . . . . 315

GANAPATI, R., REVANKAR, C. R., PANDYA, S. S. and ARCHAREKAR, M. Y., Prevalence of leprosy among in-patients in general hospitals - a survey in Bombay . . . . . . . . . . . . . . . . . . . . . . 325

GARRIGUE, R., Leprosy in China $\quad . \quad$. . . . . . . . . . . . . . . . . 29

GATNER, E. M. S., GLATthaAR, E., IMKAMP, F. M. J. H. and KOK, S. H., Association of tuberculosis and leprosy in South Africa . . . . . . . . . . 5

GATNER, E. M. S., see ANDERSON, R. . . . . . . . . . . . . . . . . . 137

GLATTHAAR, E., see GATNER, E. M. S. . . . . . . . . . . . . . . . 5

GRAINGER, C. R., Leprosy in the Seychelles . . . . . . . . . . . . . . 43 
HARRIS, E. B., see PRABHAKARAN, K.

Health education and leprosy. C. M. E. MATTHEWS, A. J. SELVAPANDIAN and M. JESUD ASAN

Health for all by the year 2000 . . . . . . . . . . . . . . . . . . . 248

Heiser Program for Research in Leprosy . . . . . . . . . . . . . . . 63, 356

Histology of the Mitsuda reaction and its significance, The. J. THOM AS, M. JOSEPH, K. RAMANUJAM, C. J. G. CHACKO and C. K. JOB . . . . . . . . . .

HLA-DR antigens in tuberculoid and lepromatous leprosy. T.H.REA and P.I.

TER ASAKI

ILEP: 33rd Meeting of the Medical Commission

Immunogenicity of killed mycobacteria. G. A. W. ROOK

Immunological aspects of leprosy, tuberculosis and leishmaniasis, Conference, Addis Ababa 1980

Immunoglobulin concentration in mothers with -leprosy and in healthy controls and their babies at the time of birth. R. MELSOM, M. E. DUNCAN and G. BJUNE . Incidence of disabilities in Hansen's disease after the commencement of chemotherapy, The. R. F. KEELER and M. A. RYAN

India embarks on multipurpose research

Influence of sulphone therapy on lepromin reaction. G. RAMU, U. SENGUPTA and K. V. DESIKAN .

Institute of Child Health, London; Child-to-Child Programme . . . . . . . . . 351

International Congress of Dermatology, XVIth, Tokyo . . . . . . . . . . . 191

International Tropical Diseases Research Fellowships . . . . . . . . . . . 85

International Workshop on Training of Leprosy Workers in Asia, 2nd . . . . . . 175

International Year of Disabled Persons, 1981 . . . . . . . . . . . . . . 351

In vitro stimulation of neutrophil motility in lepromatous leprosy. Letter to the

Editor. R. ANDERSON and E. M. S. GATNER

In vivo effects of propranolol on some cellular and humoral immune functions in a group of patients with lepromatous leprosy. R. ANDERSON, E. M. S. GATNER, F. M. J. H. IMK AMP and S. H. KOK

JANSSENS, P. G., see BERGEYCK, E. DE

Japan honours Dr Stanley Browne.

KEELER, R. F. and RYAN, M. A., The incidence of disabilities in Hansen's disease after the commencement of chemotherapy 
KIRCHHEIMER, W. F., see PRABHAKARAN, K.

KOK, S. H. see ANDERSON, R.

- , see GATNER, E. M. S.

Laboratory services at primary health care level . . . . . . . . . . . . . 181

LEPRA prize essay competition 1980 . . . . . . . . . . . . . . . . . . 258

Leprosy Conference, Third West Africa . . . . . . . . . . . . . . . . 88

Leprosy in the Americas region (AMRO). C. P. MOTTA . . . . . . . . . . . 285

Leprosy in childhood . . . . . . . . . . . . . . . . . . . . . . 192

Leprosy in China. R. GARRIGUE . . . . . . . . . . . . . . . . . . . . . 29

Leprosy Congress, The 3 rd International, Egypt . . . . . . . . . . . . . 259

Leprosy control in The Gambia. H. J. R. MEESTERS . . . . . . . . . . . 215

Leprosy Control Services as an Integral Part of Primary Health Care Programmes in

Developing Countries . . . . . . . . . . . . . . . . . . . . 81

Leprosy control in the Southern Province of Zambia. Letter to the Editor. P. A. DU

PLESSIS . . . . . . . . . . . . . . . . . . . . . . 93

Leprosy Mission, The . . . . . . . . . . . . . . . . . . . . . . 79

Leprosy in Norway. L. M. IRGENS . . . . . . . . . . . . . Supplement 1

Leprosy in the Seychelles. C. R. GRAINGER . . . . . . . . . . . . . . . . . . 43

Leprosy: Socio-economic conditions and primary health care. Letter to the Editor.

J. R. SCHMIDT . . . . . . . . . . . . . . . . . . . . . . 361

Leprosy Study Centre, London, Closure of . . . . . . . . . . . . . . . 357

Leprosy Symposium in Turkey . . . . . . . . . . . . . . . . . . . 257

Letters to the Editor:

ANDERSON, R and GATNER, E. M. S. . . . . . . . . . . . . . . 195

CASSIDY, J. T. . . . . . . . . . . . . . . . . . . . . . . 360

CHITIM BA, N. M. . . . . . . . . . . . . . . . . . . . . . . . . . 91

HARRIS, E. B. and PRABHAKARAN, K. . . . . . . . . . . . . . . . . . 359

IMKAMP, F. M. J. H. . . . . . . . . . . . . . . . . . . . . 360

PEARSON, J. M. H., HAILE, G. S., BARNETSON, R. St C. and REES, R. J. W. 262

PLESSIS, P. A. DU . . . . . . . . . . . . . . . . . . . . . . . 93

ROSS,W.F. . . . . . . . . . . . . . . . . . . . . . . . . . 197

ROSS,W.F. . . . . . . . . . . . . . . . . . . . . . . 92,197

SCHMIDT, J. R. . . . . . . . . . . . . . . . . . . . . . . . 361

SCHREUDER, P. A. M. and COLPA, L. . . . . . . . . . . . . . . 361

WARNDORFF, T. . . . . . . . . . . . . . . . . . . . . . . 262

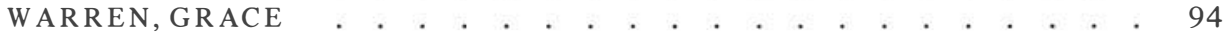

MADLENER, F., see STANFOR D, J. L. . . . . . . . . . . . . . . . . 303

Manson Medal Award to Dr R. J. W. Rees . . . . . . . . . . . . . . . 255

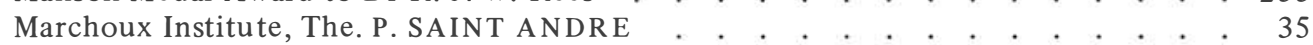

Marie Adelaide Leprosy Centre: Training courses . . . . . . . . . . . . . . . . . . . . 357

MATTHEWS, C. M. E., SELVAPANDIAN, A. J. and JESUDASAN, M., Health education and leprosy . . . . . . . . . . . . . . . . . . . . . . . 167

McD OUGALL, A. C., A guide to leprosy control; WHO/LEP/79.9 . . . . . . . 1

MEESTERS, H. J. R., Leprosy control in The Gambia . . . . . . . . . . . . . 215

MELSOM, R. and DUNCAN, M. E., Demonstration of antibodies against Mycobacterium leprae both in immunoglobulin $\mathrm{G}$ and $\mathrm{M}$ in sera from pregnant and nonpregnant lepromatous leprosy patients 
MELSOM, R., DUNCAN, M.E. and BJUNE, G., Immunoglobulin concentration in mothers with leprosy and in healthy controls and their babies at the time of birth

MODABBER, F., see STANFORD, J. L.

MOTTA, C. P., Leprosy in the Americas region (AMRO) . . . . . . . . . . 285

MUYNCK, A. DE, see BERGEYCK, E. DE . . . . . . . . . . . . . . . 221

NEMATI, T., see STANFORD, J. L. . . . . . . . . . . . . . . . . . . . . . . 303

NWUDE, N. and EBONG, OMOTAYO O., Some plants used in the treatment of leprosy in Africa

Obituaries

FOX, G. NEWBERRY . . . . . . . . . . . . . . . . . . . . 173

GILBERT, MAURICE . . . . . . . . . . . . . . . . . . . . 243

OXFAM: The Field Directors' Handbook, 1980 . . . . . . . . . . . . . . . . 353

PANDYA, S. S., see GANAPATI, R. . . . . . . . . . . . . . . . . . . . . . 325

PATOLE, A. R., see SMITH, W. C. S. . . . . . . . . . . . . . . . . . . . . 155

PATTYN, S. R., see BAQUILlON, G. . . . . . . . . . . . . . . . . . . . 315

PFAU, Dr. R., Appointment as federal advisor for leprosy to the Government of

Pakistan . . . . . . . . . . . . . . . . . . . 189

Portable slide projector, weighing less than $5 \mathrm{Kg} . \quad$. . . . . . . . . . . . . . 193

Portuguese new publications, two - translations . . . . . . . . . . . . . . . . . 190

PRABHAKARAN, K., HARRIS, E. B. and KIRCHHEIMER, W. R., Failure to detect $o$-diphenoloxidase in cultivable mycobacteria obtained from feral armadillos . . 341

Preliminary immunological studies in search of correlates of protective immunity carried out on some Iranian leprosy patients and their families. J. L. STANFORD, G. A. W. ROOK, N. SAMUEL, F. MADLENER, A. A. KHAMENEI, T. NEMATI, F. MODABBER and R. J. W. REES . . . . . . . . . . . .

Prevalence of leprosy among in-patients in general hospitals - a survey in Bombay. R. GANAPATI, C. R. REVANKAR, S. S. PANDYA and M. Y. ACHAREKAR .

Profile of urinary dapsone/creatinine ratios after oral dosage with dapsone. G. A. ELlARD . . . . . . . . . . . . . . . . . . . . . . . . 229

Quantitative study of the separation of Mycobacterium leprae from armadillo tissue. Letter to the Editor. E. B. HARRIS and K. PRABHAKARAN .

Radiological abnormalities of the ileum associated with the use of clofazimine (Lamprene; B663) in the treatment of skin ulceration due to Mycobacterium ulcerans, E. DE BERGEYCK, P. G. JANSSENS and A. DE MUYNCK . . . . . . . 22

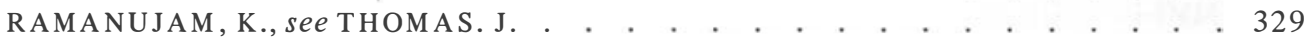

RAMU, G., SENGUPTA, U. and DESIKAN, K. V., Influence of sulphone therapy on lepromin reaction . . . . . . . . . . . . . . . . . . . . 207

RAMU, G., see BHARADWA J, V. P. . . . . . . . . . . . . . . . . . . . . . . . . . 237

REA, T. H. and TERASAKI, P. I., HLA-DR antigens in tuberculoid and lepromatous leprosy 
REES, R. J. W., see STANFORD, J. L. . . . . . . . . . . . . . . . .

Research in leprosy . . . . . . . . . . . . . . . . . . . . . . . 51

REVANKAR, C. R., see GANAPATI, R. . . . . . . . . . . . . . . . . . . . $\quad .325$

RIDLEY, D. S., Editorial, Macrophage stimulation and activity in lepromatous leprosy 111

ROOK, G. A. W., The immunogenicity of killed mycobacteria . . . . . . . . 295

-, see STANFORD, J. L. . . . . . . . . . . . . . . . . . . . . . . . 303

RYAN, M. A., see KEELER, R. F. . . . . . . . . . . . . . . . . . . 149

SAMUEL, N., see STANFORD, J. L. . . . . . . . . . . . . . . . . . . 303

Sasakawa Foundation Fellowship, 1978 . . . . . . . . . . . . . . . . . 83

Schieffelin Training Courses . . . . . . . . . . . . . . . . . . . . . . . . 86

Schisto update . . . . . . . . . . . . . . . . . . . . . . . 84,194

SELVAPANDIAN, A. J., see MATTHEWS, C. M. E. . . . . . . . . . . . . 167

SENG UPTA, U., see RAMU, G. . . . . . . . . . . . . . . . . . . . . . . . . . 207

SFG (solid, fragmented, granular) index for bacterial morphology, The. Letter to the Editor. P. A. M. SCHREUDER and L. COLPA . . . . . . . . . . . . 361

SMITH, W. C. S., ANTIN, U. S. and PATOLE, A. R., Disability in leprosy: a relevant measurement of progress in leprosy control . . . . . . . . . . . . . 155

SRITHARAN, V., see BHARADWA J, V. P. . . . . . . . . . . . . . . . . . . . . . $\quad .237$

STANFORD, J. L., ROOK, G. A. W., SAMUEL, N., MADLENER, F., KHAMENEI, A. A., NEMATI, T., MOdABBER, F. and REES. R. J. W., Preliminary immunological studies in search of correlates of protective immunity carried out on some Iranian leprosy patients and their families . . . . . . . . . . . . 303

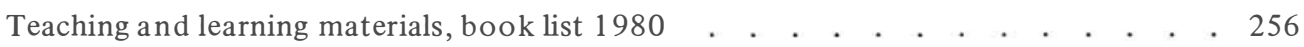

Technical guide for sputum examination for tuberculosis by direct microscopy . . . 354

TERASAKI, P. I., see REA, T. H. . . . . . . . . . . . . . . . . . . . . . . . 117

THOMAS, J., JOSEPH, M., RAMANUJAM, K., CHACKO, C. J. G. and JOB, C. K.,

The histology of the Mitsuda reaction and its significance . . . . . . . . 329

TRAUtman, Dr JOHN R., Promotion to Assistant Surgeon General, Carville Leprosarium . . . . . . . . . . . . . . . . . . . . . . . . 255

Tuberculosis, Course 941: The British Council 1980 . . . . . . . . . . . . . 248

Unit for Third World Health, Oxford . . . . . . . . . . . . . . . . . 64

VENKATESAN, K., see BHARADWAJ, V. P. . . . . . . . . . . . . . . . . . 237

WHO: Appropriate Technology for Health Directory, 1978 . . . . . . . . . . 79

Biological control of disease vectors . . . . . . . . . . . . . . 176

IMMLEP: TDR Third annual report . . . . . . . . . . . . . . . 69

International transfer of information on current drug problems . . . . . . 177

National leprosy control programmes . . . . . . . . . . . . . . . 66

Newsletter; the special programme for research and training in tropical diseases, 1980 . . . . . . . . . . . . . . . . . 259

Pictorial aids for medical teaching . . . . . . . . . . . . . . . . 193 
Report of the Steering Committee of the SWG on the chemotherapy of leprosy

(6th Meeting) . . . . . . . . . . . . . . . . . . 250

Report of SWG on the chemotherapy of leprosy (THELEP) (2nd Meeting). . . 250

Study group of nervous diseases . . . . . . . . . . . . . . . . . 72

Tropical diseases research and training . . . . . . . . . . . . . . . . . 66

Tuberculosis experts meet to discuss lack of protection of BCG vaccines in trial . 179

WAlTER, Dr J., Geneva . . . . . . . . . . . . . . . . . . . 356

Water and development . . . . . . . . . . . . . . . . . . . 177

Weekly epidemiological records: leprosy surveillance . . . . . . . . . . 67

World Directory of Medical Schools, 5th edn . . . . . . . . . . 249,352 